UNIVERSIDADE DE SÃO PAULO

INSTITUTO DE GEOCIÊNCIAS

\title{
PETROGRAFIA E QUÍMICA MINERAL DAS INTRUSÕES INDAIÁ I E INDAIÁ II, OESTE DO ESTADO DE MINAS GERAIS
}

SIMONE DA SILVA

Orientador: Prof ${ }^{\circ}$. Dr. Excelso Ruberti

DISSERTAÇÃO DE MESTRADO

Programa de Pós-Graduação em Mineralogia e Petrologia

SÃO PAULO

2008 


\section{Índice}

Agradecimentos..................................................................................................... xiii

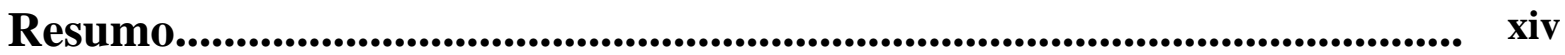

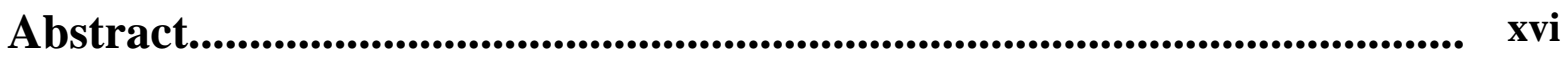

1. Introdução...................................................................................... 01

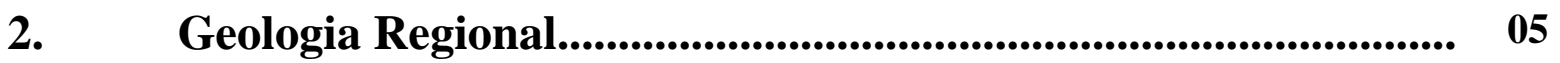

2.1. O Cráton do São Francisco........................................................................ 05

2.2. A Faixa Brasília................................................................................ $\quad 07$

2.3. O Arco do Alto Paranaíba................................................................................ 12

2.4. A Bacia do Paraná no Oeste Mineiro......................................................... 12

2.5. Província Ígnea do Alto Paranaíba................................................................... 13

3. Materiais e Métodos............................................................. 15

3.1. Trabalho de Campo................................................................................. 15

3.2. Localização e Acessos......................................................................... 15

3.3. Trabalhos de Laboratório...................................................................... 15

3.4. Química Mineral.................................................................................................. 17

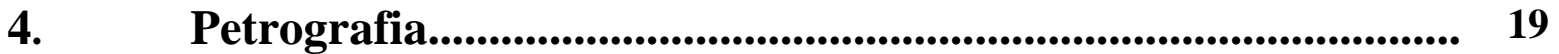

4.1. Intrusão Indaiá I............................................................................ 19

4.2. Intrusão Indaiá II.......................................................................... 23

4.3. Xenólitos.......................................................................................... 26

4.3.1 Intrusão Indaiá I.......................................................................... 26

4.3.2 Intrusão Indaiá II......................................................................... 30

5. Química Mineral................................................................. 37

5.1. Intrusão Indaiá I...................................................................................... 37

5.1.1 Olivina......................................................................................... 37

5.1.2 Piroxênios.................................................................................... 43

5.1.3 Ilmenita........................................................................................ 47

5.1.4 Grupo dos espinélios.......................................................................... 50

5.1.5 Monticellita........................................................................................ 53

5.1.6 Perovskita................................................................................................. 54

5.2. Intrusão Indaiá II................................................................................... 58

5.2.1 Olivina......................................................................................... 58

5.2.2 Piroxênios.......................................................................................... $\quad 60$

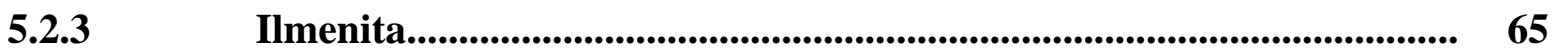

5.2.4 Grupo dos espinélios..................................................................... 67

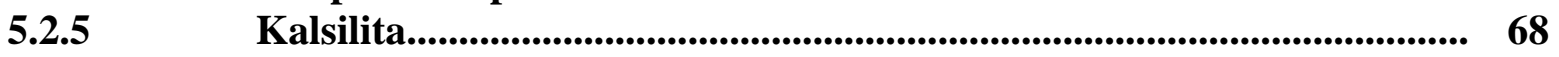

5.2.6 Perovskita................................................................................... 71 
6. Considerações petrográficas e mineralógicas das Intrusões

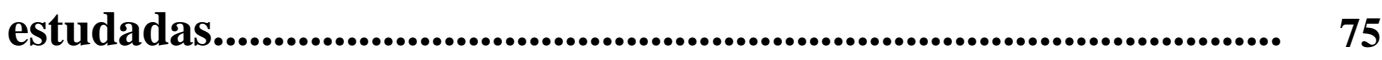

6.1 Comparação entre as intrusões Indaiá I e Indaiá II.................................... 75

6.1.1 Comparação das características petrográficas.......................................... $\quad 75$

6.1.2 Comparação entre a química mineral........................................................ 77

6.2 A nomenclatura das rochas máfica-ultramáficas, potássica ultrapotássicas: kimberlitos, orangeitos, lamproítos kamafugitos e lamprófiros.................................................................................................... 79

6.2.1 Kimberlitos..................................................................................................... 79

6.2.2 Orangeitos..................................................................................... 8

6.2.3 Lamproítos....................................................................................................... 81

6.2.4 Kamafugitos.......................................................................................... 83

6.2.5 Lamprofíros.................................................................................................. 84

6.3 Proposta de nomenclatura para as rochas que compõem as intrusões

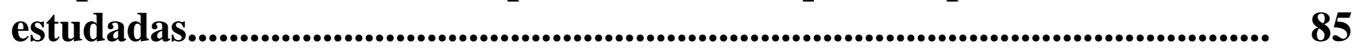

6.3.1 Intrusão I.................................................................................................. 85

6.3.2 Intrusão II......................................................................................... 92

7. Considerações sobre potencial econômico e região fonte das intrusões Indaiá - I e II..................................................................... 103

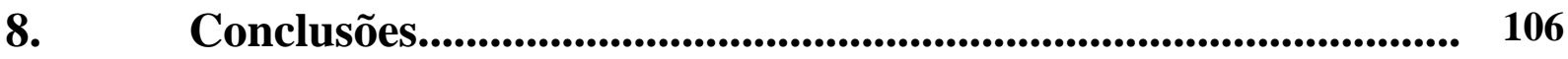

9. Referências Bibliográficas...................................................... 108 


\section{Índice das Figuras}

Figura 1. Mapa geológico da região abrangida Província Ígnea do Alto Paranaíba.....

Figura 2. $\quad$ Imagem de satélite mostrando as intrusões Indaiá I (SW da estrada vicinal) e Indaiá II (NE da estrada vicinal), oeste do Estado de Minas Gerais. (Fonte: Image TerraMetrics 2006, programa Google Earth).....

Figura 3.

Mapa geológico do cráton do São Franciso (modificado de Alkmim et al.1993)

Figura 4. Esboço tectônico do Brasil Central (simplificado de Almeida et al. 1981).

Figura 5. Unidades tectônicas da Faixa Brasília (compilado de Dardenne, 2000; Pimentel et al. 2000; Valeriano et al. 2000; Seer, 1999; Silva, 2003)....

Figura 6

Principais unidades tectônicas da Faixa Brasília Meridional no segmento Araxá (compilado de Valeriano et al. 2004).

Figura 7. Mapa de localização com as principais vias de acesso à área das intrusões estudadas.

Figura 8A. Fotomicrografia da rocha da intrusão Indaiá I. Textura porfirítica seriada da rocha, com destaque para xenólito piroxenítico(XP); xenólito carbonatítico (XC); fenocristal de olivina (FO). Polarizadores descruzados. Amostra 11B 1.

Figura 8B. $\quad$ Fotomicrografia da rocha da intrusão Indaiá I. Textura porfirítica seriada da rocha, com destaque para: fenocristal de olivina (FO); melilita alterada (M). Polarizadores descruzados. Amostra 11D2.....

Figura 8C. Fotomicrografia da rocha da intrusão Indaiá I. Textura porfirítica seriada da rocha, com destaque para: xenólito piroxenítico (XP); fenocristal de olivina (FO); macrocristal de olivina (MO). Polarizadores cruzados. Amostra 01B A

Figura 8D. Fotomicrografia da rocha da intrusão Indaiá I. Destaque para os componentes da matriz: cristais de olivina (O), opacos (OP), carbonatos $(\mathrm{C})$, monticellita $(\mathrm{MON})$ e perovskita $(\mathrm{P})$. Polarizadores descruzados. Amostra 11B1

Figura 9A. $\quad$ Fotomicrografia da rocha da intrusão Indaiá I. Cristais de perovskita (P) em borda de mineral opaco. Polarizadores descruzados. Amostra 08B2

Figura 9B. Fotomicrografia da rocha da intrusão Indaiá I. Destaque para os componentes da matriz: clinopiroxênio (diopsidio) esverdeado (D), carbonato esbranquiçado (C), agregado de opacos e perovskitas. Polarizadores descruzados. Amostra 02A. 
Figura 9C. Fotomicrografia da rocha da intrusão Indaiá I. Destaque para os componentes da matriz: clinopiroxênio (diopsídio) esverdeado (D), carbonato esbranquiçado (C), opacos (O) e perovskitas. Polarizadores descruzados. Amostra 06B B.

Figura 9D. Fotomicrografia da rocha da intrusão Indaiá I. Fenocristais e cristais de olivina (O) bordejada por bowlingita (B). Polarizadores descruzados. Amostra 02C (A).

Figura 10A. Fotomicrografia da rocha da intrusão Indaiá I. Cristais de olivina (O) bordejada por bowlingita (cinza) e clorofaeita (esverdeadas). Polarizadores cruzados. Amostra 11B2.

Figura 10B. Fotomicrografia da rocha da intrusão Indaiá I. Fenocristais de olivina zonados. Polarizadores cruzados. Amostra 4A1.

Figura 10C. Fotomicrografia da rocha da intrusão Indaiá I. Fenocristais de olivina zonados. Polarizadores cruzados. Amostra 06C.

Figura 10D. Fotomicrografia da rocha da intrusão Indaiá I. Fenocristais de olivina zonados. Polarizadores cruzados. Amostra 11D2.

Figura 11A. Fotomicrografia da rocha da intrusão Indaiá I. Fenocristal anédrico de mineral opaco. Polarizadores descruzados. Amostra 11B1.

Figura 11B. Fotomicrografia da rocha da intrusão Indaiá I. Aglomerado composto por cristais minerais opacos e perovskita. Polarizadores descruzados. Amostra 06BA

Figura 11C. Fotomicrografia da rocha da intrusão Indaiá I. Fino intercrescimento de minerais opacos. Luz refletida. Amostra 06C.

Figura 11D. Fotomicrografia da rocha da intrusão Indaiá I. Microfenocristais de melilita (M), alterado e deformados. Polarizadores cruzados. Amostra 02A.

Figura 12A. Fotomicrografia da rocha da intrusão Indaiá I. Microfenocristais de melilita (M), alterado e deformado. Polarizadores cruzados. Amostra 11B1

Figura 12B. Fotomicrografia da rocha da intrusão Indaiá I. Macrocristais de ortopiroxênio (enstatita - ferrossilita) com borda quelifitizada. Polarizadores descruzados. Amostra 04A1

Figura 12C. Fotomicrografia da rocha da intrusão Indaiá I. Detalhe de macrocristal de ortopiroxênio (demarcado em amarelo) apresentado na Figura 12B. Polarizadores descruzados. Amostra 04A1....

Figura 12D. Fotomicrografia da rocha da intrusão Indaiá II. Textura porfirítica, com fenocristais de olivina. Observe os xenólitos estirados (XE). Polarizadores descruzados. Amostra 28A. 
Figura 13A. Fotomicrografia de rocha da intrusão II. Textura porfirítica, com fenocristal de olivina. Observem-se os xenólitos estirados (XE). Polarizadores descruzados. Amostra 25A.

Figura 13B. Fotomicrografia de rocha da intrusão II. Matriz com diopsídio, opacos (OP), perovskita (P) e olivina (O). Amostra 21A.

Figura 13C. Fotomicrografia de rocha da intrusão II. Matriz com diopsídio, opacos (OP), perovskita (P) e olivina (O). Observe macrocristais de espinélio (ES). Polarizadores descruzados. Amostra 24A(A).

Figura 13D Fotomicrografia de rocha da intrusão II. Macrocristal de olivina com bordas corroídas. Polarizadores descruzados. Amostra 28A.

Figura 14A. Fotomicrografia de rocha da intrusão II. Fenocristais anédricos de olivina. Polarizadores descruzados. Amostra 21A

Figura 14B. Fotomicrografia de rocha da intrusão II. Fenocristais de olivina com bordas corroídas. Polarizadores descruzados. Amostra 28A.

Figura 14C. Fotomicrografia de rocha da intrusão II. Cristal de mineral opaco apresentando bolsões de matriz (embayment). Polarizadores descruzados. Amostra 19B.

Figura 14D. Fotomicrografia de rocha da intrusão II. Mineral opaco (OP) apresentando inclusão de matriz. Polarizadores descruzados. Amostra $19 \mathrm{~A}$

Figura 15A. Fotomicrografia de rocha da intrusão II. Cristais de mineral opaco (OP), olivina (O) e perovskita (P). Polarizadores descruzados. Amostra 28A

Figura 15B. Fotomicrografia de rocha da intrusão II. Micro venulação com bordas de richterita alaranjada (R) e opacos, preenchida por agregado de minerais incolores. Polarizadores descruzados. Amostra 16A1.

Figura 15C. Fotomicrografia de rocha da intrusão II. Micro venulação com bordas de diopsídio preenchida por vidro parcialmente devidrificado. Polarizadores descruzados. Amostra 16A1

Figura 15D. Fotomicrografia de rocha da intrusão II. Microvenulação com bordas de diopsídio preenchida por vidro (VV) e scherbakivita (S). Polarizadores descruzados. Amostra 02A.

Figura 16A. Fotomicrografia de rocha da intrusão II. Micro venulação com bordas de diopsídio preenchida por scherbakivita (S). opaco (OP); perovskita (P). Polarizadores cruzados. Amostra 11E (A).

Figura 16B. Fotomicrografia de rocha da intrusão I. Xenólito carbonatítico (destacado em vermelho) incluso em xenólito "lapilli” (destacado em amarelo); olivina (O). Polarizadores descruzados. Amostra 11B2......... 
Figura 16C. Fotomicrografia de rocha da intrusão I. Xenólito carbonatítico (destacado em vermelho) incluso em xenólito "lapilli” (destacado em amarelo); olivina (O). Polarizadores descruzados. Amostra 11B1....

Figura 16D. Fotomicrografia de rocha da intrusão I. Matriz de xenólito "lapilli”. Olivina (O); perovskita (P); diopsídio (D). Polarizadores descruzados. Amostra 02A

Figura 17A. Fotomicrografia de rocha da intrusão I. Xenólito carbonatítico. Polarizadores descruzados. Amostra 11E (A)

Figura 17B. Fotomicrografia de rocha da intrusão I. Matriz de xenólito carbonatítico. Polarizadores cruzados. Amostra 11B2...

Figura 17C. Fotomicrografia de rocha da intrusão I. Xenólito dunítico. Polarizadores descruzados. Amostra 11D2.

Figura 17D. Fotomicrografia de rocha da intrusão I. Xenólito dunítico. Polarizadores cruzados. Amostra 1B(A).

Figura 18A. Fotomicrografia de rocha da intrusão I. Xenólito dunítico. Polarizadores cruzados. Amostra 11E (A)....

Figura 18B. Fotomicrografia de rocha da intrusão I. Xenólito piroxenítico. Opacos (OP); diopsídio (D); flogopita (F). Polarizadores cruzados. Amostra 04B1

Figura 18C. Fotomicrografia de rocha da intrusão I. Xenólito piroxenítico. Opacos (OP); diopsídio (D); flogopita (F). Polarizadores cruzados. Amostra 06C.

Figura 18D. Fotomicrografia de rocha da intrusão I. Fragmento de xenólito piroxenítico. Polarizadores descruzados. Amostra 06B(B).

Figura 19A. Fotomicrografia de rocha da intrusão I. Xenólito piroxenítico. Opacos (OP); diopsídio (D); flogopita (F). Polarizadores descruzados. Mostra 01B(B).

Figura 19B. Fotomicrografia de rocha da intrusão II. Xenólito dunítico. Olivina (O); scherbakovita (S). Polarizadores descruzados. Amostra 28B.........

Figura 19C. Fotomicrografia de rocha da intrusão II. Idem a figura anterior. Polarizadores descruzados. Amostra 28B.

Figura 19D. Fotomicrografia de rocha da intrusão II. Xenólito microcristalino. Polarizadores descruzados. Amostra 28B.

Figura 20A. Fotomicrografia de rocha da intrusão II. Xenólito microcristalino. Polarizadores descruzados. Amostra 25B..... 
Figura 20B. Fotomicrografia de rocha da intrusão II. Minerais inclusos no xenólito microcristalino. Nefelina (N); diopsídio (D); scherbakovita (S); opacos (OP). Polarizadores cruzados. Amostra 28B.

Figura 20C. Fotomicrografia de rocha da intrusão II. Xenólito “lapilli”(destacado em amarelo), apresentando inclusão de fragmentos angulosos de xenólito carbonatítico (destacado em vermelho). Polarizadores descruzados. Amostra 19A.

Figura 20D. Fotomicrografia de rocha da intrusão II. Detalhe do xenólito "lapilli”(destacado em amarelo), apresentando inclusão de fragmentos angulosos de xenólito carbonatítico (destacado em vermelho). Polarizadores descruzados. Amostra 19A.

Figura 21A. Fotomicrografia de rocha da intrusão II. Xenólito carbonatitíco. Polarizadores descruzados. Amostra 19A

Figura 21B. Fotomicrografia de rocha da intrusão II. Vista geral de xenólito carbonatitíco. Polarizadores descruzados. Amostra 19BA.

Figura 21C. Fotomicrografia de rocha da intrusão II. Xenólito nefelinítico. Polarizadores descruzados. Amostra 22

Figura 21D. Fotomicrografia de rocha da intrusão II. Xenólito nefelinítico. Nefelina (N); kalsilita (K); opacos (OP); scherbakovita (S). Polarizadores descruzados. Amostra 22.

Figura 22. Histograma de composição química para macrocristais de olivina de Indaiá I.

Figura 23. Histograma de composição química para fenocristais de olivina de Indaiá I.

Figura 24. Histograma de composição química para olivinas presentes nos xenólitos de Indaiá I.

Figura 25A. Diagrama de classificação de piroxênios segundo Morimoto (1990), onde $\mathrm{Q}=\mathrm{Ca}+\mathrm{Mg}+\mathrm{Fe} 2 \mathrm{e} \mathrm{J}=2 \mathrm{Na}$..

Figura 25B. Diagrama ternário de classificação de clinopiroxênios (En - Fs - Wo), onde $\mathrm{En}=100 \mathrm{Mg} /(\mathrm{Ca}+\mathrm{Mg}+\mathrm{Fe} 2+\mathrm{Fe} 3+\mathrm{Mn}+\mathrm{Na}), \mathrm{Fs}=100(\mathrm{Fe} 2+$ $\mathrm{Fe} 3+\mathrm{Mn}) /(\mathrm{Ca}+\mathrm{Mg}+\mathrm{Fe} 2+\mathrm{Fe} 3+\mathrm{Mn}+\mathrm{Na}) \mathrm{e} \mathrm{Wo}=100 \mathrm{Ca} /(\mathrm{Ca}+$ $\mathrm{Mg}+\mathrm{Fe} 2+\mathrm{Fe} 3+\mathrm{Mn}+\mathrm{Na})$.

Figura 25C. Diagrama ternário de classificação de ortopiroxênios, onde En = $100 \mathrm{Mg} /(\mathrm{Ca}+\mathrm{Mg}+\mathrm{Fe} 2+\mathrm{Fe} 3+\mathrm{Mn}+\mathrm{Na}), \mathrm{Fs}=100(\mathrm{Fe} 2+\mathrm{Fe} 3+$ $\mathrm{Mn}) /(\mathrm{Ca}+\mathrm{Mg}+\mathrm{Fe} 2+\mathrm{Fe} 3+\mathrm{Mn}+\mathrm{Na})$ e $\mathrm{Wo}=100 \mathrm{Ca} /(\mathrm{Ca}+\mathrm{Mg}+$ $\mathrm{Fe} 2+\mathrm{Fe} 3+\mathrm{Mn}+\mathrm{Na}) \cdot \mathrm{Q}=\mathrm{Ca}+\mathrm{Mg}+\mathrm{Fe} 2+; \mathrm{J}=2 \mathrm{Na}$; Wo, wollastonita; En, enstatita; Fs, ferrosilita 
Figura 26. Composição de ilmenitas (mol\% em peso) de Indaiá I em diagrama triangular Fe2O3 - MgTiO3 - FeTiO3. No lado direito, o diagrama apresenta os campos de variação das ilmenitas analisadas para os fenocristais, matriz, xenólito piroxenítico, xenólito dunítico e inclusões de olivina.

Figura 27. Diagrama $\mathrm{Cr}-\mathrm{Al}-\left(\mathrm{Fe}^{2+}+2 \mathrm{Ti}\right)$ para espinélios da intrusão Indaiá I. Modificado de Melluso et al., 2007.....

Figura 28. C Composição de perovskitas da intrusão Indaiá I (\% mol) no sistema perovskita - loparita - lueshita.

Figura 29. Histograma de composição química para os macro e fenocristais de olivina de Indaiá II.....

Figura 30A. Diagrama de classificação de piroxênios segundo Morimoto (1990), onde $\mathrm{Q}=\mathrm{Ca}+\mathrm{Mg}+\mathrm{Fe} 2$ e $\mathrm{J}=2 \mathrm{Na}$;

Figura 30B. Diagrama ternário de classificação de clinopiroxênios (En - Fs - Wo), onde $\mathrm{En}=100 \mathrm{Mg} /(\mathrm{Ca}+\mathrm{Mg}+\mathrm{Fe} 2+\mathrm{Fe} 3+\mathrm{Mn}+\mathrm{Na}), \mathrm{Fs}=100(\mathrm{Fe} 2+$ $\mathrm{Fe} 3+\mathrm{Mn}) /(\mathrm{Ca}+\mathrm{Mg}+\mathrm{Fe} 2+\mathrm{Fe} 3+\mathrm{Mn}+\mathrm{Na}) \mathrm{e} \mathrm{Wo}=100 \mathrm{Ca} /(\mathrm{Ca}+$ $\mathrm{Mg}+\mathrm{Fe} 2+\mathrm{Fe} 3+\mathrm{Mn}+\mathrm{Na})$.

Figura 31. $\quad$ Composição de ilmenitas (mol\% em peso) de Indaiá II em diagrama triangular $\mathrm{Fe}_{2} \mathrm{O}_{3}-\mathrm{MgTiO}_{3}-\mathrm{FeTiO}_{3}$. No lado direito, o diagrama apresenta os campos de variação das ilmenitas analisadas para os cristais da matriz e xenólito dunítico.

Figura 32. Diagrama $\mathrm{Cr}-\mathrm{Al}-\left(\mathrm{Fe}^{2+}+2 \mathrm{Ti}\right)$ para espinélios da intrusão IndaiáII. Modificado de Melluso et al., 2007.

Figura 33. C Composição de perovskitas da intrusão Indaiá II (\% mol) no sistema perovskita - loparita - lueshita.

Figuras 34A. Modelo de estruturas intrusivas de pipes. (Extraído de Gonzaga \& Tompkins, 1991).

Figuras 34B. Modelo de estruturas intrusivas de pipes lamproíticos. (Extraído de Gonzaga \& Tompkins, 1991).

Figura 35A. Diagrama ternário Mg-Fe-Ca comparando a variação composicional de ortopiroxênios de Indaiá I com os campos composicionais de ortopiroxênios dos kimberlitos Monastery, Sloan - Nix, Letseng-laterae e Mukorob (adaptado de Mitchell, 1986).

Figura 35B. Trends composicionais de espinélios provenientes de kimberlítos (T1 - trend de ulvoespinélio magnesiano; T2 - trend de titanomagnetita), orangeítos e lamproítos. Modificado de Mitchell, 1995. 
Figura 36A. Composição de ilmenitas da intrusão Indaiá I (\% em peso) no diagrama $\mathrm{TiO} 2$ vs $\mathrm{MgO}$, com os campos composicionais de ilmenitas de kimberlitos não cratônicos do Grupo I (África do Sul/Namibia). Modificado de Wyatt, 2004.

Figura 36B. Composição de ilmenitas da intrusão Indaiá I (\% em peso) no diagrama $\mathrm{Cr} 2 \mathrm{O} 3$ vs $\mathrm{MgO}$ (B), com os campos composicionais de ilmenitas de kimberlitos não cratônicos do Grupo I (África do Sul/Namibia). Modificado de Wyatt, 2004......

Figura 37. Composição de ilmenitas da intrusão Indaiá I no sistema MgTiO3FeTiO3-Fe2O3, comparados com o campo composicional de ilmenitas kimberlíticas, basaltos alcalinos, alnoitos Malaita (Lesoto) e basanitos Ahaggar (sul da Argelia). Campos A e B, representam, respectivamente, composições de ilmenitas de granitos e carbonatitos. (Modificado de Mitchell, 1986)......

Figura 38. Ilmenitas da intrusão Indaiá I locadas no sistema ternário geikielita ilmenita-pirofanita, juntamente com os campos composicionais de ilmenitas dos orangeítos Lace e Sover Miner, carbonatitos e kimberlitos (adaptado de Mitchell, 1995).

Figura 39. Composição de perovskitas (\% mol.) de Indaiá I locadas no sistema ternário perovskita - lueshita - loparita. (Modificado de Mitchell, 1995).

Figura 40A. Fotomicrografia de rochas da intrusão Indaiá II. Xenólito nefelinítico, com bordas irregulares e parcialmente estirado, fixado em matriz sem evidente orientação de fluxo. Polarizador descruzado. Lâmina IN 24E.

Figura 40B. Fotomicrografia de rochas da intrusão Indaiá II. Detalhe da estrutura demarcada em vermelho da Figura 40A, no xenólito nefelinítico, destacando os cristais de nefelina - kalsilita presentes no interior dos xenólitos. Polarizador descruzado. Lâmina IN 24E...

Figura 41. Clinopiroxênios da intrusão Indaiá II locados no diagrama diagrama Al vs Ti e comparados com os campos composicionais de orangeítos e lamproítos, lamproíto Kapamba (Índia), minettes, kamafugitos de Uganda e lavas da Província Romana. Modificado de Mitchell, 1995...

Figura 42. Espinélios da intrusão Indaiá II locados em trends composicionais de kimberlítos (T1 - trend ulvoespinélio magnesiano; T2 - trend titanomagnetita), orangeítos e lamproítos. Modificado de Mitchell 1995.

Figura 43A. Composição de ilmenitas da intrusão Indaiá II (\% em peso) no diagrama $\mathrm{TiO} 2$ vs $\mathrm{MgO}$, com os campos composicionais de ilmenitas de kimberlitos não cratônicos do Grupo I (África do Sul/Namibia). Modificado de Wyatt, 2004. 
Figura 43B. Composição de ilmenitas da intrusão Indaiá II (\% em peso) no diagrama $\mathrm{Cr} 2 \mathrm{O} 3$ vs $\mathrm{MgO}$ (B), com os campos composicionais de ilmenitas de kimberlitos não cratônicos do Grupo I (África do Sul/Namibia). Modificado de Wyatt, 2004...

Figura 44. Composição de ilmenitas da intrusão Indaiá II no sistema $\mathrm{MgTiO}_{3}$ $\mathrm{FeTiO}_{3}-\mathrm{Fe}_{2} \mathrm{O}_{3}$, comparados com o campo composicional de ilmenitas kimberlíticas, basaltos alcalinos, alnoitos Malaita (Lesoto) e basanitos Ahaggar(sul da Argelia). Campos A e B, representam, respectivamente, composições de ilmenitas de granitos e carbonatitos. (Modificado de Mitchell, 1986)

Figura 45. Ilmenitas da intrusão Indaiá II locadas no sistema ternário geikielita ilmenita-pirofanita, juntamente com os campos composicionais de ilmenitas dos orangeítos Lace e Sover Miner, carbonatitos e kimberlitos (adaptado de Mitchell, 1995)

Figura 46. C Composição de perovskitas (\% mol.) de Indaiá II locadas no sistema ternário perovskita - lueshita - loparita. (Modificado de Mitchell, 1995).

Figura 47. Composições de ilmenitas do segmento Brasiliano e das intrusões Indaiá I e Indaiá II, locadas em diagrama Cr2O3 vs MgO (\%mol). Curva parabólica proposta por Haggerty (1975) e divisão dos campos diamantíferos e não diamantiferos proposta por Parfenoff (1982). Modificado de Gonzaga \& Tompkins, 1991... 


\section{Índice das Tabelas}

Tabela 1. Coluna estratigráfica da bacia do Paraná no oeste mineiro

Tabela 2. Condições Analíticas da microssonda eletrônica para os minerais

Tabela 3.

Composição química de macrocristais de olivina de Indaiá I......

Tabela 4.

Composição química de macrocristais de olivina de Indaiá I.

Tabela 5.

Composição química de fenocristais de olivina de Indaiá I.

Tabela 6.

Composição química de cristais de olivina presentes em xenólitos da intrusão Indaiá I.

Tabela 7. Composição química de macrocristais de ortopiroxênios da intrusão Indaiá I.........

Tabela 8. Composição química de piroxênios de xenólitos piroxeníticos da intrusão Indaiá I.

Tabela 9. Composição química de ilmenita de xenólitos piroxeníticos e duníticos, de inclusões em olivina e dispersos na matriz.

Tabela 10. Composição química de fenocristais de ilmenitas de Indaiá I.

Tabela 11. Composição química de minerais do grupo dos espinélios - cromita e espinélios de Indaiá I.

Tabela 12. Composição química de minerais do grupo dos espinélios - magnetitas de Indaiá I.

Tabela 13. Composição química de monticellita em cristais da matriz das rochas de Indaiá I.

Tabela 14. Composição química de perovskita em cristais que compõe a matriz da rocha da intrusão Indaiá I.

Tabela 15. Composição química de macro cristais e fenocristais de olivina de Indaiá II......

Tabela 16. Composição química de microfenocristais de piroxênios de Indaiá II

Tabela 17. Composição química de cristais de piroxênios da matriz das rochas de Indaiá II e de seus xenólitos duníticos.

Tabela 18. Composição química de ilmenitas presentes na matriz das rochas de Indaiá II e nos xenólitos duníticos.

Tabela 19. Composição química de minerais do grupo dos espinélios das rochas de Indaiá II e nos xenólitos duníticos 
Tabela 20. Composição química de mineral do grupo da nefelina presentes em xenólitos microcristalino da intrusão das rochas de Indaiá II.

Tabela 21. Composição química de perovskitas de Indaiá II. 


\section{Agradecimentos}

Desejo expressar os meus mais sinceros agradecimentos às diversas pessoas e instituições que auxiliaram na execução deste trabalho.

Isto posto, agradeço primeiramente à minha família pelo apoio e compreensão dispensados nas diversas fases que compuseram a execução e término desse trabalho.

Meus agradecimentos ao Professor Doutor Excelso Ruberti pela orientação, dedicação, apoio, discussões e paciência, dispensados durante todo o tempo levado para a execução desta dissertação. Ao Professor Doutor Darcy Pedro Svisero pelas inesquecíveis aulas de campo no Triângulo Mineiro e a apresentação das intrusões Indaiá. À Professora Doutora Gianna Maria Garda pela revisão ao abstract.

Sou grata a chefia Geóloga Karine da Silva Glória, pelo apoio e discussões sobre “o sexo do kimberlito”. À FAPESP - Fundação de Amparo à Pesquisa do Estado de São Paulo através do Processo 01/10743-3, e ao CNPq - Conselho Nacional de Desenvolvimento Científico e Tecnológico, através do Processo 303428/2005-8, pela concessão de recursos para a realização dos trabalhos de campo e das análises realizadas nos laboratórios.

Não poderia deixar de agradecer a amiga Geóloga Silvia Cristina Benitez Gonzáles pelo carinho e apoio durante toda a minha jornada.

Agradeço às Secretárias do Departamento de Mineralogia e Geotectônica, as Sras. Valéria Cristina Santos e Sônia Gomes C. Vieira; às funcionárias da Biblioteca Sras. Brenda Mascarenhas, Érica do Nascimento e Maria Aparecida Ayello; aos funcionários da Seção de Pós-Graduação Sras. Ana Paula Cabanal e Magali F. Rizzo e ao Sr. Tadeu Caggiano; ao Sr. José Paulo do Laboratório de Preparação de Amostras; aos funcionários do Setor de Laminação, Srs. Cláudio Hopp, Paulo Roberto Molinaro, Paulo Augusto Morgato, Luiz Cláudio Nogueira.

Agradeço também aos funcionários da Gráfica, aos Srs. Claudionor Barbosa, Edmir de Oliveira e Henrique Martins responsáveis pela encadernação dos volumes finais dessa Dissertação.

Meus agradecimentos ao Sr. Marcos Mansueto, pela assistência nas atividades durante a obtenção dos dados de química mineral no Laboratório de Microssonda Eletrônica do Departamento de Mineralogia e Geotectônica; à Sra. Angélica Morente, pelo auxílio durante as atividades realizadas no Laboratório de Óptica do Departamento de Mineralogia e Geotectônica.

A todos os profissionais e amigos que, de uma forma ou outra, colaboram neste trabalho e que por descuido não tenham sido mencionados, apresento os meus mais sinceros agradecimentos. 


\section{Resumo}

A presente dissertação se ocupou da investigação petrográfica e química mineral de rochas ultramáficas, potássica-ultrapotássicas, insaturadas em sílica, de afinidade kimberlítica, das intrusões Indaiá I e Indaiá II, oeste do Estado de Minas Gerais. Estas rochas afloram na Província Ígnea do Alto Paranaíba (PIAP, Cretáceo Superior), dentro de uma área alongada segundo N30W, perfazendo aproximadamente $250 \mathrm{~km}$ de extensão e $70 \mathrm{~km}$ de largura. As suítes do PIAP encontram-se à margem oeste do Cráton do São Francisco, alojadas em litologias pertencentes próprio Cráton e à Faixa Brasília.

Os dados petrográficos, dentro das suas limitações, principalmente no que tange à sobreposição de características entre as rochas dos clãs kimberlitos, lamproítos, kamafugitos, orangeitos e lamprófiros, denotam na intrusão Indaiá I a presença de texturas porfiríticas, compostas de mega e fenocristais anédricos a subédricos de olivina, opacos e mais raramente de enstatita, fixados em matriz afanítica formada de cristais anédricos de olivina (crisolitaforsterita), minerais opacos, monticellita tabular, cristais amarronzados subédricos de perovskita, clinopiroxênio (diopsídio) esverdeado e carbonatos. Já na intrusão II se observa a presença de fenocristais anédricos a subédricos de olivina, fixados em matriz afanítica contendo alguns microfenocristais, prismáticos a subédricos, de clinopiroxênio diopsídico esverdeado, cristais anédricos de minerais opacos associados a espinélio avermelhado, cristais subédricos a anédricos de perovskita, grãos arredondados de olivina e também raro vidro intersticial, embora já devidrificado.

A composição mineral observada nas rochas da intrusão Indaiá I é representada essencialmente por cristais de crisolita - forsterita $\left(\mathrm{Mg} / \mathrm{Mg}+\mathrm{Fe}^{2+}\right.$ de 83 a 95), enstatita $\left(\mathrm{En}_{85,3} \mathrm{Fs}_{12,7} \mathrm{Wo}_{1,54}\right)$, ilmenita magnesiana, Cr-espinélio representados por espinélio e membros da série chromite-magnetite-ulvöspinélio, monticellita (92\% do membro final $\mathrm{CaMgSiO}_{4}$ ) e perovskita (93\% do membro final $\mathrm{CaTiO}_{3}$ ). Na intrusão Indaiá II, a assembléia mineral presente é bastante similar à observada na intrusão I, contudo com um piroxênio diopsídico mais enriquecido em cálcio $\left(\mathrm{En}_{39,7} \mathrm{Fs}_{10,2} \mathrm{Wo}_{48,0}\right)$ e ausência de minerais espinélio e monticellita.

Com base na conjunção das características petrográficas e químicas dos minerais descritas no presente trabalho, propõe-se para as rochas das duas intrusões uma afinidade kimberlítica, pertencente ao clã dos kimberlitos do Grupo I.

Apesar das ilmenitas magnesianas possuirem composições indicativas de que o líquido gerador das rochas favorece a preservação de diamantes, posto a inexistência de macrocristais de cromita com alta porcentagem de $\mathrm{Cr}_{2} \mathrm{O}_{3}$ e granadas $\mathrm{G} 10$ e/ou eclogitícas com altos teores de Na2O, a propensão à mineralização é frustada, isto porque, aparentemente, estas intrusões 
não amostraram xenólitos e macrocristais situados dentro da região do campo de estabilidade dos diamantes.

As rochas de Indaiá I e Indaiá II apresentam uma assembléia mineral com possibilidades de existência de diamantes. As ilmenitas magnesianas presentes nessas rochas possuem uma composição indicativa de um ambiente gerador favorável à preservação de diamantes. Entretanto, a inexistência de macrocristais de cromita com alta porcentagem de $\mathrm{Cr}_{2} \mathrm{O}_{3}$ e de granadas do tipo G10 e/ou eclogitícas com altos teores de $\mathrm{Na}_{2} \mathrm{O}$ frusta essa propensão à mineralização. Isto porque, estas intrusões aparentemente não amostraram xenólitos e macrocristais de alta pressão situados dentro da região do campo de estabilidade dos diamantes no manto. 


\begin{abstract}
An integrated petrographic and mineral chemistry study has been carried out on ultramafic, potassic to ultrapotassic and silica-undersaturated rocks of kimberlitic affinity of the Indaiá I and Indaiá II intrusions, Western Minas Gerais State, Brazil.

These rocks outcrop at the Alto Paranaíba Igneous Province (PIAP), within a N30W-trending, elongated area, which is $250-\mathrm{km}$ long and $70-\mathrm{km}$ wide. The PIAP suites are located on the western border of the São Francisco Craton and are emplaced in a basement composed of rocks from the Craton itself and late Proterozoic Brasília fold belt.

Within the limitations imposed by the overlapping mineralogical characteristics of the kimberlite, lamproite, kamafugite, orangeite and lamprophyre clans, petrographic data show differences in the Indaiá I and II mineralogical compositions. Indaiá I consists of olivine, opaque mineral and orthopyroxene megacrysts and phenocrysts set in an aphanitic groundmass of olivine, opaque minerals, tabular monticellite, subeuhedral brown perovskite, green diopside and carbonates, whereas Indaiá II comprises anhedral to subeuhedral olivine phenocrysts set in an aphanitic matrix of prismatic to subeuhedral greenish diopside microphenocrysts, anhedral opaque minerals and related brownish spinel, perovskite, rounded olivine and occasional interstitial (devitrified) glass.

The Indaiá I mineral chemistry comprises chrysolite to forsterite $\left[83<\mathrm{Mg} /\left(\mathrm{Mg}+\mathrm{Fe}^{2+}\right)<\right.$ 95], enstatite $\left(\mathrm{En}_{85.3} \mathrm{Fs}_{12.7} \mathrm{Wo}_{1.54}\right)$, magnesian ilmenite, Cr-bearing spinels from spinel to chromite-magnetite-ulvöspinel members, monticellite (92 mol\% $\mathrm{CaMgSiO}_{4}$ end-member), and perovskite (93 mol\% $\mathrm{CaTiO}_{3}$ end-member).

Indaiá II is similar to Indaiá I, except for the slightly Ca-enriched diopsidic clinopyroxene ( $\left.\mathrm{En}_{39.7} \mathrm{Fs}_{10.2} \mathrm{Wo}_{48.0}\right)$, and the lack of spinels and monticellite.

On the basis of petrographic characteristics and mineral chemistry, it is proposed that the rocks from both Indaiá I and II belong to the Group I kimberlites. Both the intrusions are similar to many Group I kimberlites of the world and comprise some minerals that indicate the possible presence of diamonds, such as the magnesian ilmenite, whose composition reflects generation conditions to preserve diamonds. However, the generalized lack of chromite macrocrysts with high $\mathrm{Cr}_{2} \mathrm{O}_{3}$ contents and $\mathrm{G} 10$ and/or eclogitic garnets with high $\mathrm{Na}_{2} \mathrm{O}$ contents attests for the lack of diamonds, once these intrusions have not sampled highpressure xenoliths and macrocrysts within the diamond stability field in the mantle.
\end{abstract}




\section{Introdução}

A Província Ígnea do Alto Paranaíba (PIAP, Figura 1), oeste do Estado de Minas Gerais, encontra-se comumente associada a uma zona de lineamentos NW-SE de rochas ígneas alcalinas cretáceas, que se estende por cerca de $2000 \mathrm{~km}$. A província coincide com uma série de faixas móveis proterozóicas situadas ao redor das margens da Bacia do Paraná (Herz, 1977; Almeida 1986; Almeida \& Svisero, 1991) e representa uma das mais volumosas $\left(>15.000 \mathrm{~m}^{3}\right)$ províncias ultramáficas potássica conhecidas do mundo. Compõe-se de complexos carbonatíticos maiores e intrusões alcalinas menores relacionadas, além de rochas vulcânicas, tufos, lavas e depósitos piroclásticos associados ao Grupo Mata da Corda (Leonados et al., 1991). Estudos geoquímicos regionais destas ocorrências (Gibson et al., 1995) demonstram que a PIAP consiste de uma relativa diversidade de suítes, lavas e intrusões potássicas-ultrapotássicas, máficas-ultramáfica, insaturadas em sílica, representadas por rochas do grupo dos kimberlito, kamafugito e lamproíto, rochas estas com elevada concentração de elementos traço e fortemente enriquecidas em elementos terras raras pesados. Determinações isotópicas K/Ar em micas revelam que tais rochas se colocaram sincronicamente aos complexos carbonatíticos, com idade em torno de $85 \mathrm{Ma}$ (Gibson et al., 1995).

Nas regiões de Catalão (I e II), Serra Negra, Salitre, Araxá e Tapira, em Minas Gerais, ocorrem grandes complexos carbonatíticos contendo reservas de nióbio, fosfato, titânio e elementos terras raras. Esses complexos mostram um estágio evolutivo inicial representado por micaperidotitos e piroxenitos, seguidos por um estágio carbonatítico com o desenvolvimento de carbonatos, flogopita, perovskita, apatita, ilmenita e outras fases. O estágio hidrotermal completa a seqüência gerando carbonato remobilizado, sulfetos, barita e quartzo (Danni et al. 1991; Mariano \& Marchetto, 1991). Datações K/Ar do carbonatito de Catalão deram idades de aproximadamente 83 Ma (Cordani \& Hasui, 1968). Estudos de traços de fissão em apatitas do carbonatito de Serra Negra indicam idades limites compreendidas entre 97 e 87 Ma (Eby \& Mariano 1986).

Estruturas ígneas menores encontram-se distribuídas em toda a província do Alto Paranaíba e ocorrem como intrusões isoladas, geminadas ou múltiplas. Na região leste da província, ocorrem lavas e depósitos piroclásticos que são referidos como Formação Mata da Corda (Leonardos et al. 1991). As evidências geológicas (Figura 1) sugerem que essas ocorrências vulcânicas podem ter coberto uma porção ainda mais ampla do Alto Paranaíba, posteriormente varrida pela erosão. As determinações radiométricas $\mathrm{Rb} / \mathrm{Sr}$ e $\mathrm{Ar} / \mathrm{Ar}$ em mica de várias intrusões (Bizzi et al. 1993, Gibson et al. 1997) demonstraram idades entre 84 e 85 Ma.

A nomenclatura de muitas das intrusões menores é ainda uma questão em aberto. As feições texturais, mineralógicas e geoquímicas das rochas que compõem essas intrusões sugerem mais de 
uma tipologia litológica, incluindo variedades da linhagem de kimberlitos, lamproítos, olivina melilititos e kamafugitos.

A discussão sobre a natureza petrográfica e classificação das rochas alcalinas e diversidades correlatas, bem como a origem e evolução dos magmas que geraram essas rochas, mantém-se como um tópico de grande interesse desde o final do século XIX, em virtude do grande interesse econômico como também científico dessas associações.

Do ponto de vista econômico, os maciços alcalinos são as principais fontes de óxidos e/ou silicatos de nióbio, titânio, zircônio, urânio, tório, tântalo, alumínio, berílio e sódio, além de importantes concentrações de fosfatos e de terras raras. Os maiores depósitos conhecidos no mundo de $\mathrm{Nb}$, terras raras, $\mathrm{Hf}$, e $\mathrm{Sr}$ estão relacionados com o magmatismo alcalino. Cite-se como exemplo, os depósitos minerais de fosfatos (Araxá, Jacupiranga, Juquiá, Tapira), titânio (Serra Negra, Tapira), nióbio (Araxá). Os kimberlitos e lamproítos ocorrem de forma correlata ao magmatismo alcalino e também contêm reservas importantes de minerais, os diamantes.

Sob o aspecto científico, os estudos petrogenéticos dessas associações procuram compreender os mecanismos formadores da litodiversidade coexistente dentro de cada centro magmático intrusivo, como também a profundidade da fonte magmática e a evolução dos magmas, além do contexto da atividade alcalina regional das províncias magmáticas alcalinas.

Sabe-se, no entanto, que o conhecimento das associações alcalinas brasileiras como um todo é ainda bastante restrito, particularmente ao se considerar aquelas com afinidades kimberlíticas e lamproíticas, as quais foram alvo de atenção principalmente das empresas com interesse econômico.

Os trabalhos desenvolvidos na presente pesquisa tiveram como objetivo principal a caracterização petrológica de intrusões ultrabásicas potássicas de afinidade kimberlítica/kamafugítica da PIAP, entre os vilarejos de Monte Carmelo e Abadia dos Dourados, MG, tendo como alvo principal as intrusões Indaiá I e Indaiá II (Figura 2). O estudo pormenorizado da petrografia e da química mineral constituiu o enfoque primordial desta dissertação. Além disso, esta pesquisa procurou comparar o quadro petrográfico e mineralógico dessa intrusão com o de outras ocorrências congêneres estudadas na PIAP e de algumas da literatura internacional, de linhagem das rochas kimberlíticas, kamafugíticas e lamproíticas, com vistas a estabelecer uma definição petrológica mais precisa dessas intrusões. 


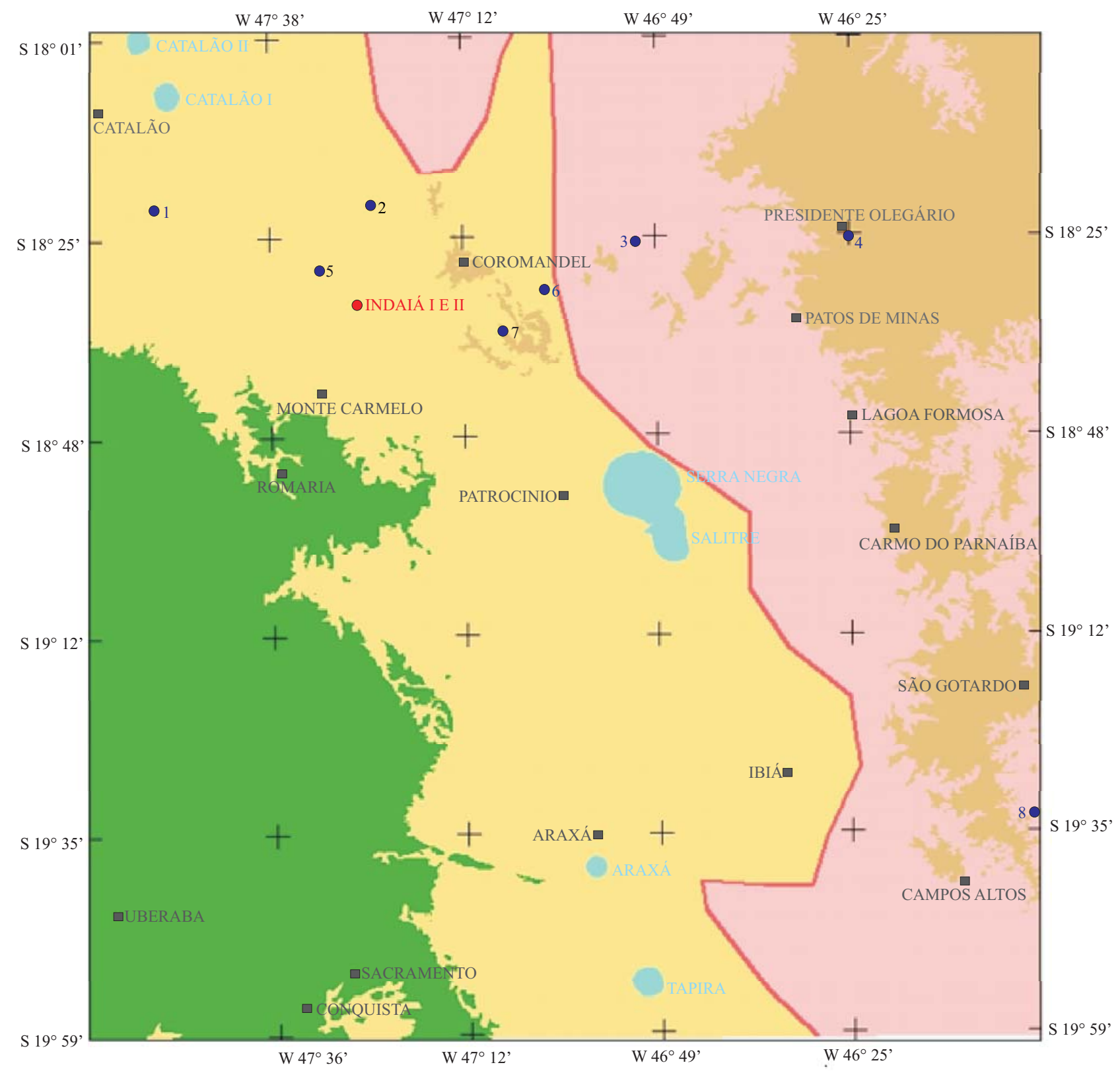

\section{LEGENDA}

INTRUSÕES INDAIÁ I E II

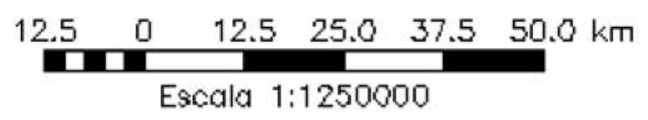

- INTRUSÕES KIMBERLÍTICAS CONHECIDAS (1 - Três Ranchos; 2 - Japecanga; 3 - Pântano; 4 Facão; 5 - Limeira; 6 - Vargem; 7 - Veridiana; 8 Cana Verde)

COMPLEXOS CARBONATÍTICOS

BACIA SANFRANCISCANA (Porção Sul)

BACIA DO PARANÁ

FAIXA BRASÍLIA

CRÁTON DO SÃO FRANCISCO

LIMITE DO CRÁTON

CIDADES

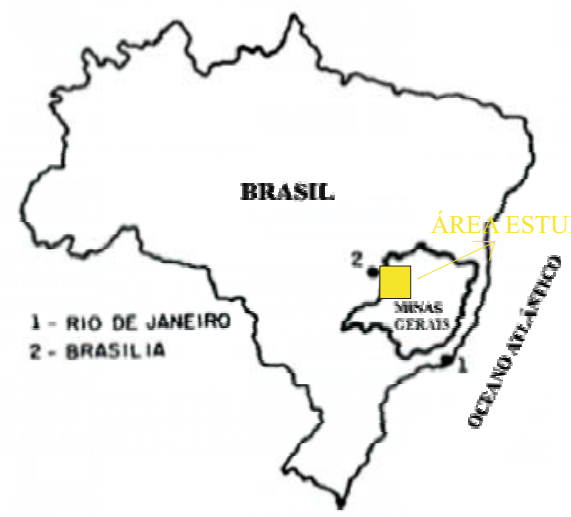

Figura 1. Mapa geológico da região abrangida Província Ígnea do Alto Paranaíba. 


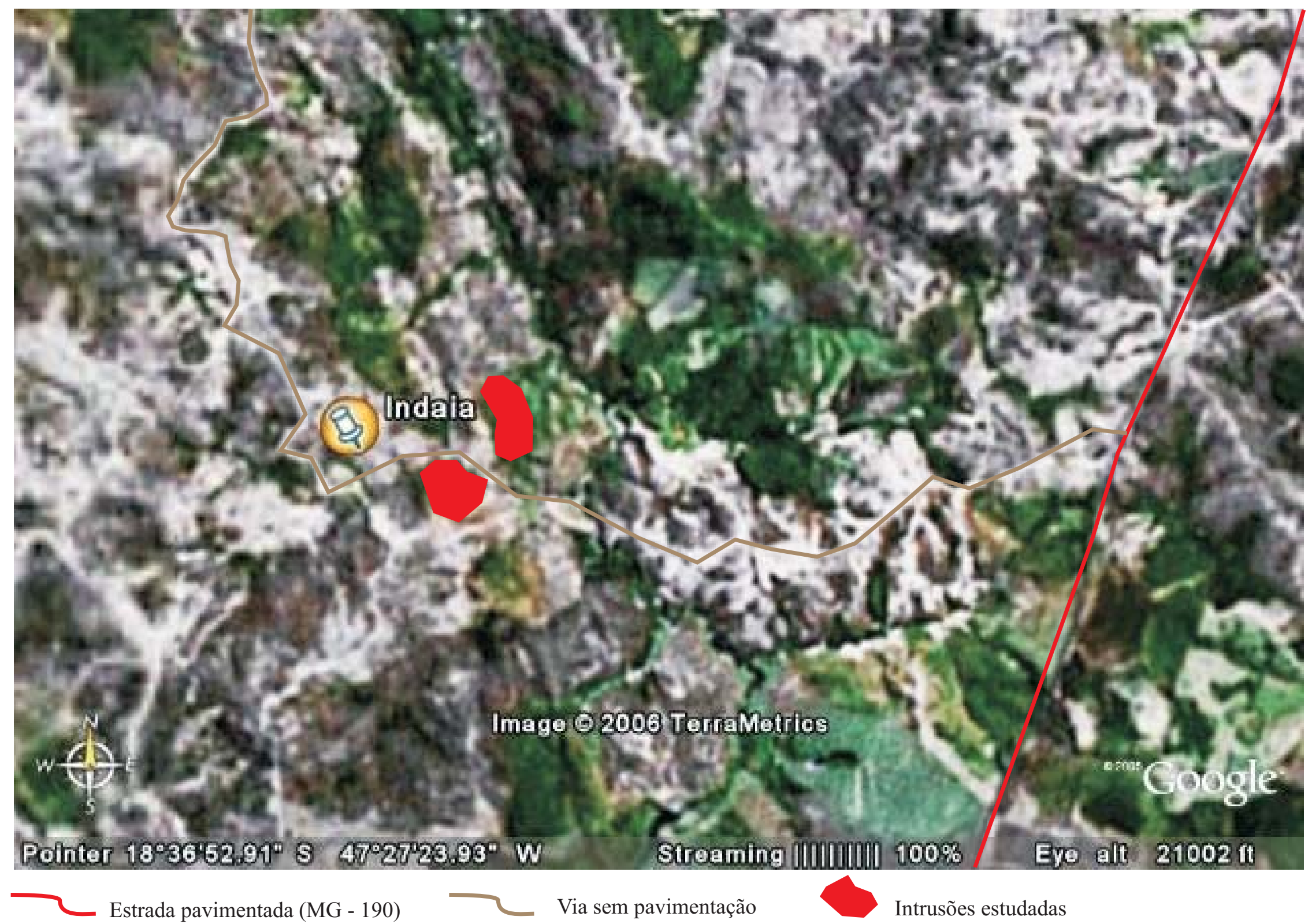

Figura 2. Imagem de satélite mostrando as intrusões Indaiá I (SW da estrada vicinal) e Indaiá II (NE da estrada vicinal), oeste do Estado de Minas Gerais. (Fonte: Image TerraMetrics 2006, programa Google Earth) 


\section{Geologia Regional}

Na região que se estende entre as cidades de Catalão, a noroeste e Tapira, ao sul, afloram uma série de suítes potássicas/ultrapotássicas e máficas/ultramáficas, comumente concentradas em área alongada segundo N $30 \mathrm{~W}$, perfazendo aproximadamente $250 \mathrm{~km}$ de extensão e $70 \mathrm{~km}$ de largura. Essas suítes encontram-se à margem oeste do Cráton do São Francisco, alojadas em litologias pertencentes Cráton e a Faixa Brasília.

\subsection{O Cráton do São Francisco}

O Cráton do São Francisco (CSF, Almeida 1967, Teixeira et al. 2000) está situado na parte centro-oeste da América do Sul (Figura 3), representando a melhor e a mais acessível exposição de escudo pré-cambriano brasileiro. Acha-se de praticamente encoberto por grandes unidades morfotectônicas (Bacia do São Francisco, o aulacógeno do Paramirim e grande parte do "rift" Recôncavo - Tucano) e bacias neoproterozóicas de antepais. No extremo sul e leste do escudo, essas unidades são parcialmente recobertas pelos grupos Bambuí e Paranoá (Neoproterozóico) e sedimentos fanerozóicos.

Os limites de CSF, traçados ao longo de zonas de suturas nos orógenos brasilianos, acham-se representados a sul e a oeste pela Faixa Brasília, a noroeste pela Faixa Rio Preto, a norte pelas Faixas Riacho do Pontal e Sergipana e leste pela Faixa Araçuaí, indo de encontro às bacias do Jequitinhonha, Almada Camamu e Jacuipe. Seu embasamento é formado por um núcleo arqueano consolidado (2,6 Ga), que estabilizou-se após o término do Evento Transamazônico. A partir daí, deu-se a formação de complexa cobertura sedimentar, armazenada nas bacias do São Francisco e no aulacógeno Paramirim. Nestes sítios, registram-se duas fases de rifteamento (1,75 Ga e $950 \mathrm{Ma})$, inversão parcial durante o evento Brasiliano no Neoproterozóico, glaciação permo-carbonífera de residência Gondwânica e marcantes repercussões da abertura do Atlântico no Eocretáceo, com renovado riffteamento (Alckmin 2004). 


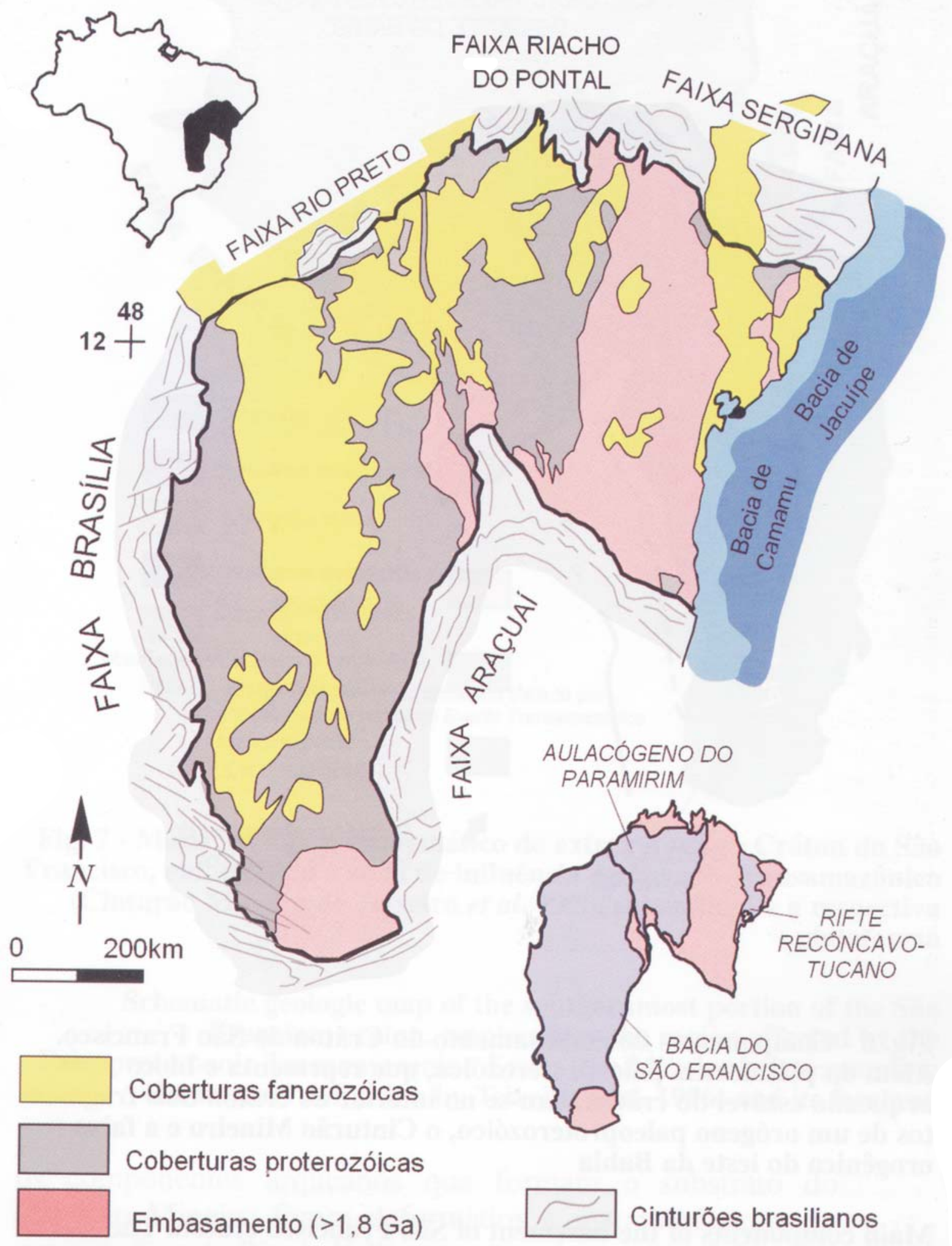

Figura 3. Mapa geológico do cráton do São Franciso (modificado de Alkmim et al.1993). 


\subsection{A Faixa Brasília}

A faixa Brasília (FB) é uma importante feição geológica de metassedimentos, que se estende cerca de $1.100 \mathrm{~km}$ em direção norte - sul e baliza a margem ocidental oeste do CSF. A estrutura é considerada parte de um orógeno neoproterozóico desenvolvido entre os crátons do São Francisco, Amazônico e um terceiro, hoje encoberto por rochas sedimentares da Bacia do Paraná (Pimentel et al., 2004; Figura 4). Sua seqüência terrígena inferior (Almeida 1967) compreende o Grupo Canastra e parte dos Grupos Araxá e Bambuí (Fuck et al. 1993).

Segundo Marini et al. (19981), Fuck (1984) e Dardenne (2000), a FB é definida como um conjunto de terrenos e escamas de empurrão de escala crustal, que converge para leste contra o CSF (vide Figura 5). Sua compartimentação tectônica é marcada por dois ramos de distinta orientação e estilos metamórficos deformacionais: a Faixa Brasília Setentrional (FBS), de orientação NE e a Faixa Brasília Meridional (FBM), de orientação NW. Esses dois ramos se encontram à altura do Paralelo de Brasília, formando a Megaflexura do Pirineus (Costa \& Angeiras, 1971) marcada por lineamentos de orientação $\mathrm{E}-\mathrm{W}$.

A zona de antepaís da FB, também, é marcada por empurrões rasos e superfícies subhorizontais de deslocamento que afetam os sedimentos anquimetamórficos plataformais neoproterozóicos do Grupo Bambuí (Dardenne, 2000), com rara ou nenhuma participação de rochas de seu embasamento paleoproterozóico - arqueano (estilo “thin skinned”). Para leste, esse domínio faz limite gradativo com a área autóctone, virtualmente indeformada, do Grupo Bambuí e de seu embasamento cratônico, e a oeste é recoberto bruscamente pela frente alóctone das nappes de cavalgamento mais externas da FBM (Alkmin et al., 1993).

A faciologia sedimentar e as características geoquímicas/geocronológicas apontam para uma ambientação de margem passiva. Porções da bacia de fácies mais distais (talude, sopé continental e assoalho oceânico) se empilharam tectonicamente sobre as fácies de plataforma mais proximal. As escamas de empurrão ("nappes") inferiores apresentam metamorfismo de fácies xisto verde e as superiores tendem a apresentar fácies anfibolito e granulito. Nas rochas de alto grau de metamorfismo têm sido observados gradientes de alta pressão (Simões, 1995; Campos Neto \& Caby, 1999 a, b), sugerindo que, num estágio precoce da orogênese, a margem continental sanfranciscana mais distal foi subduzida parcialmente sob a placa e/ou terrenos colidentes vindos de oeste, sendo em seguida exumada e empurrada sobre as escamas mais próximas ao antepaís. 


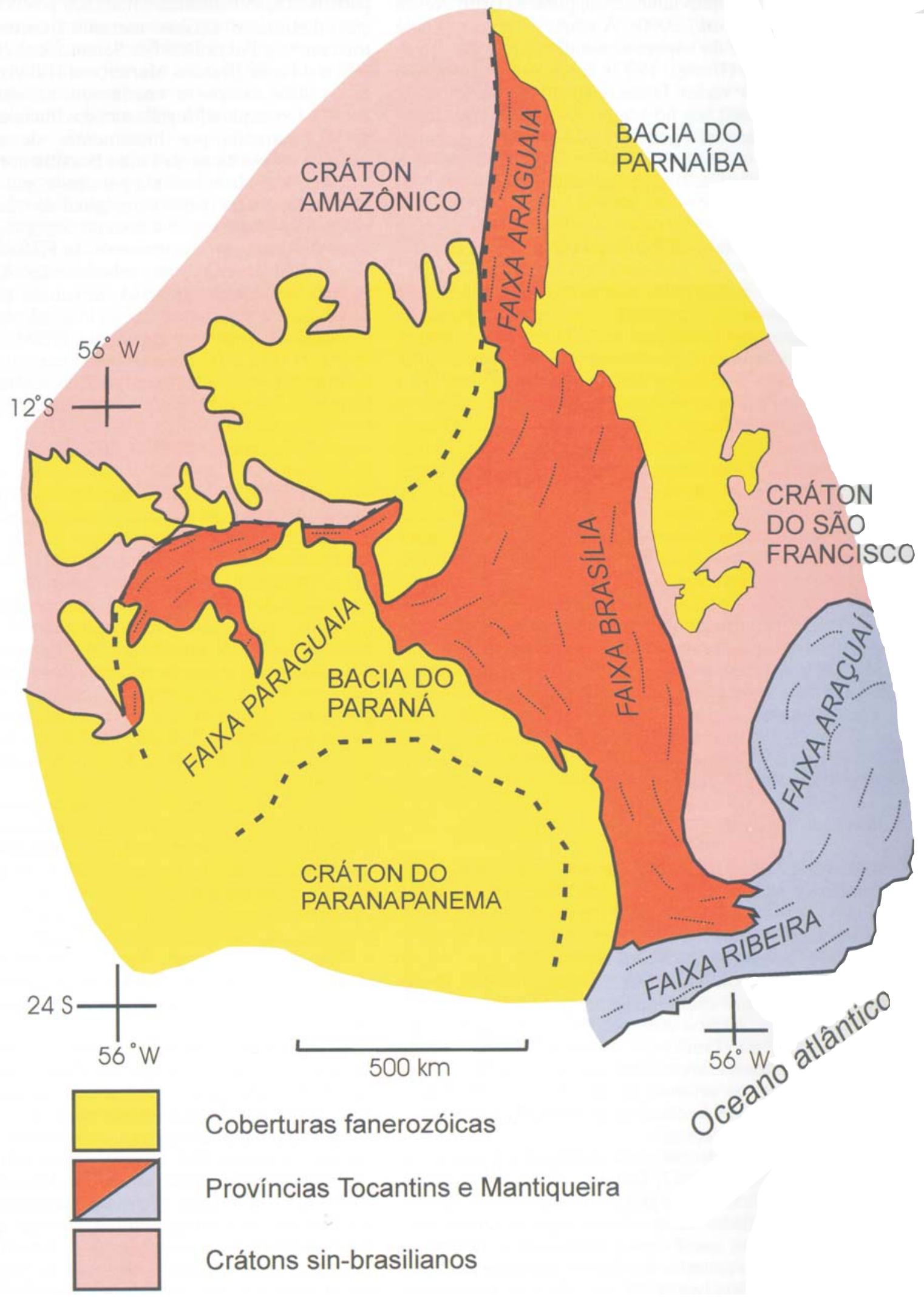

Figura 4. Esboço tectônico do Brasil Central (simplificado de Almeida et al. 1981). 


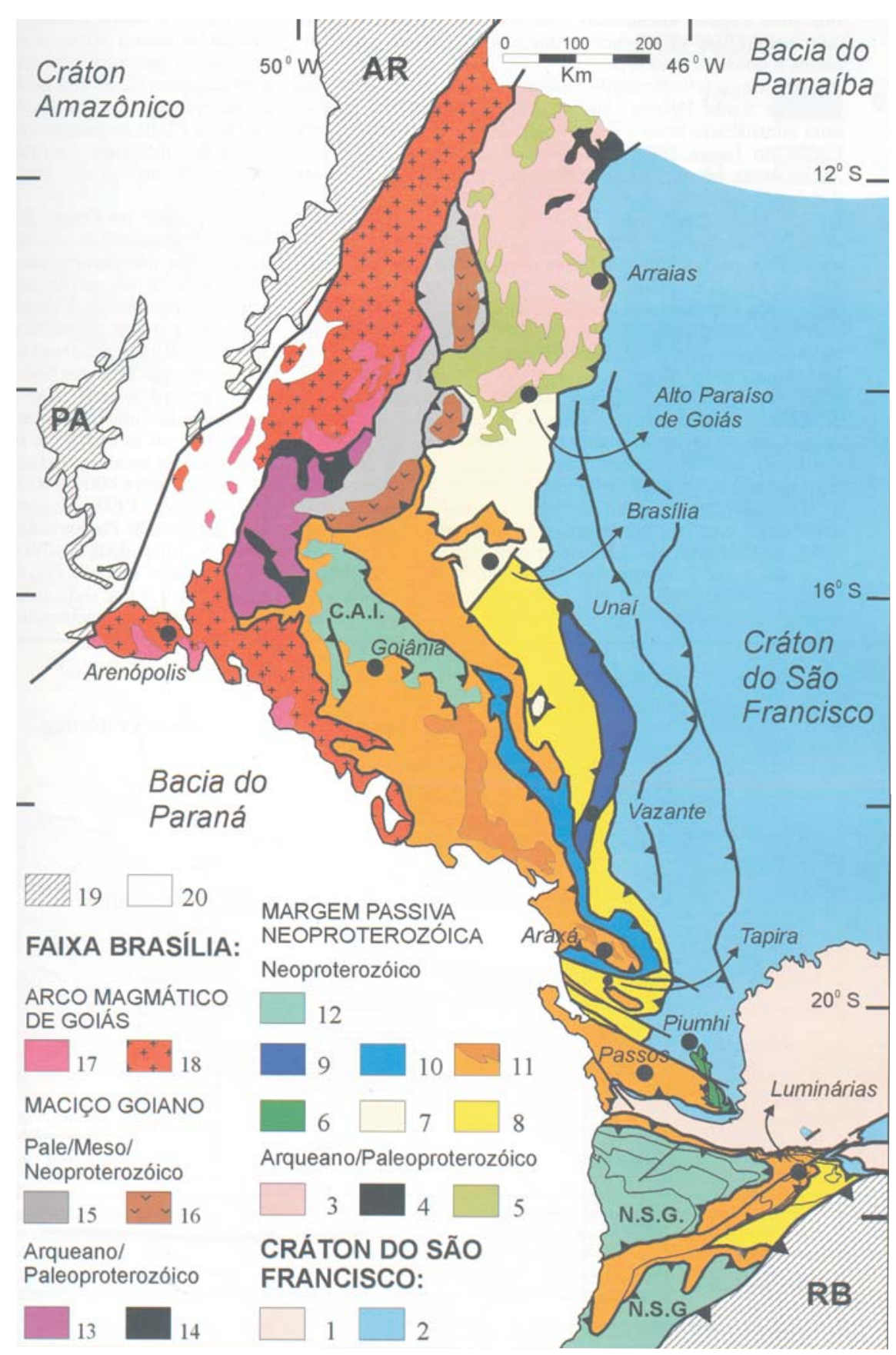

LEGENDA: 1 - Terrenos granito-greenstone e gnaisse-migmatíticos arqueano/paleoproterozóicos; 2 Coberturas metassedimentares autócnes/parautócnes (Grupos São João Del Rei, Carandaí, Andrelândia, Bambuí); 3 - Terrenos granito-greenstone, gnaisse-migmatíticos arqueano/paleoproterozóicos; 4 - Greenstone-belts arqueano/paleoproterozóicos; 5 - Sucessão de rifte paleo a mesoproterozóico (Grupo Irai); 6 - Sistema de cavalgamento Ilicínea-Piumhi, sucessões neoproterozóicas de margem passiva; 7 - Grupo Paranoá; 8 - Grupo Canastra; 9 - GrupoVazante; 10 Grupo Ibiá; 11 - Grupos Araxá e Andrelândia e rochas metabásicas toleíticasassociadas; complexos de melanges ofiolíticas; lascas de embasamento alóctone, granitos leucocráticos sincolisionais, 12 Nappes granulíticas (Complexo Anápolis-Itauçu - CAI e Nappe Socorro-Guaxupé - NSG); 13 Complexos granito-gnaisse- migmatíticos arqueano/paleoproterozóicos; 14 - Grrenstone-belts arqueano/paleoproterozóicos; 15 - Sucessões vucano-sedimentares de rifte mesoproterozóico (Juscelândia, Palmeiropólis e Serra da Mesa); 16 - Complexos básicos-ultrabásicos acamadados meso/neoproterozóicas; 17 - Sucessões vulcano-sedimentares meso a neoproterozóicas; 19 - Faixas

Figura 5. Unidades tectônicas da Faixa Brasília (compilado de Dardenne, 2000; Pimentel et al. 2000; Valeriano et al. 2000; Seer, 1999; Silva, 2003). 
Após a colisão continental, que deu origem à Faixa Brasília, a região ficou estabilizada até o Cretáceo Inferior, quando se iniciou um processo de formação de diques de diabásio associados ao vulcanismo toleítico da Formação Serra Geral, Bacia do Paraná, (Brod et al., 1991; Dardenne, 2000). Esses diques são marcados por forte anomalia magnética, que definiriam a estruturação do Arco do Alto Paranaíba. Este, um alto topográfico que separou a sedimentação cretácea da Bacia Sanfranciscana da Bacia do Paraná.

Face à localização das intrusões em escopo, no presente trabalho, faz-se necessário uma breve apresentação das principais feições tectônicas da FBM (Figura 6).

A FBM é caracterizada (Valeriano et al., 2004) por um empilhamento de extensas "nappes" de cavalgamento subhorizontais, formadas predominantemente de rochas da margem passiva sanfranciscana e empurradas em direção ao CSF por volta de $640 \mathrm{Ma}$. Em seu conjunto, o grau metamórfico e a intensidade da deformação ligada ao cisalhamento de baixo mergulho aumentam consideravelmente, embora não continuamente, da área cratônica até a zona mais interna da faixa. Nos seus estágios mais tardios, a deformação passa para um estilo dominado por dobramentos mais abertos, associados a falhas transcorrentes sinistrais de direção NW-SE, que resultaram na fragmentação da FBM em segmentos deslocados (Luminária, Passos, Tapira, Araxá - Goiânia).

A porção alóctone da FBM (Figura 6) consiste do empilhamento tectônico de vários terrenos tectono-estratigráficos, limitados por importantes superfícies de cavalgamento, a maioria das quais representando majoritariamente por uma unidade litoestratigráfica metassedimentar, tais como o Grupo Vazante (inferior), Canastra, Ibiá, Paranoá e Araxá - Andrelândia (superior). Descontinuidades metamórficas podem ocorrer entre os terrenos adjacentes, mostrando que o empilhamento tectônico se deu posteriormente ao apogeu térmico que suas rochas vivenciaram. 


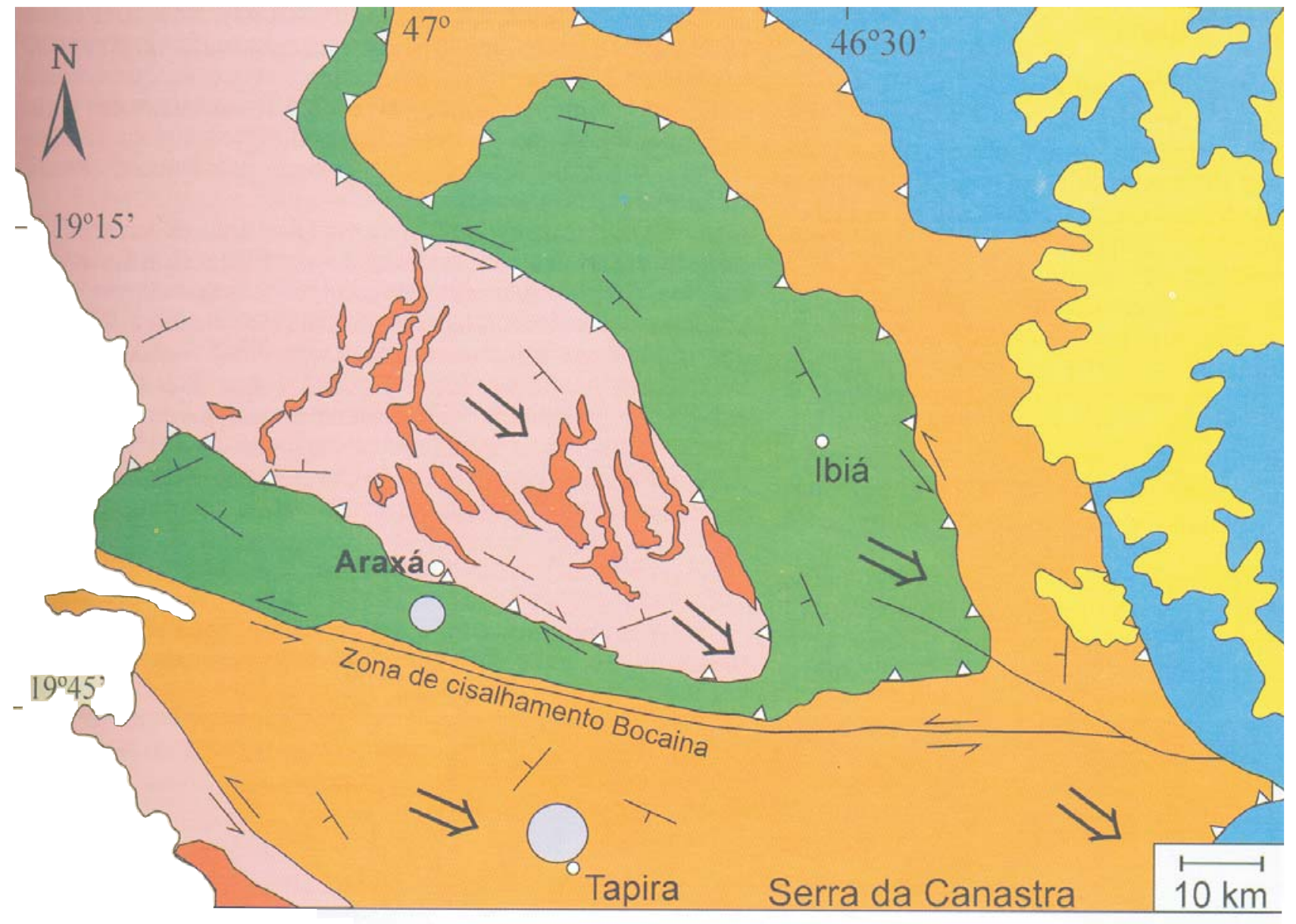

LEGENDA: Neoproterozóico: 1- Cobertura autóctone (Grupo Bambuí). 2 - Lasca inferior (Grupo Canastra); 3 - Lasca intermediária (Grupo Ibiá); 4 Lasca superior (Grupo Araxá com granitos sin-colisionais). Fanerozóico: 5 - Bacia do Paraná; 6 - Bacia São Franciscana; 7 - Complexo carbonatítico; 8 - Falha de empurrão; 9 - Falha transcorrente; 10 - Foliação S2; 11 - Cidade; 12 Transporte tectônico principal (fase D2).

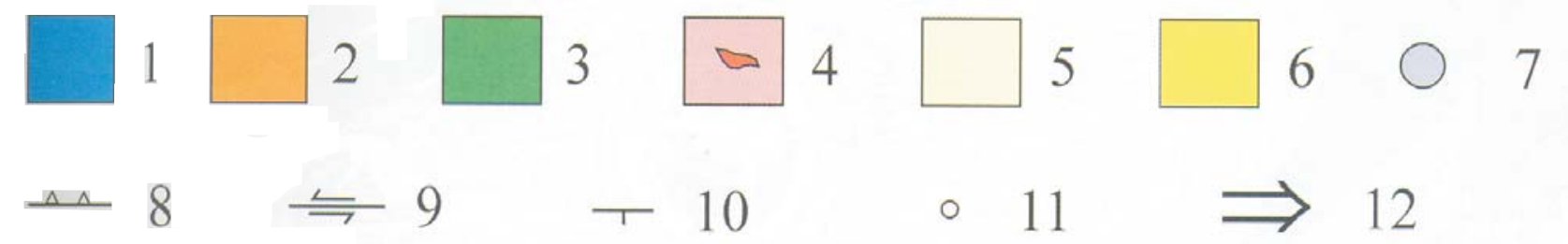

Figura 6. Principais unidades tectônicas da Faixa Brasília Meridional no segmento Araxá (compilado de Valeriano et al. 2004). 


\subsection{O Arco do Alto Paranaíba}

Os derrames basálticos da Bacia do Paraná (137 a 127 Ma, Turner et al. 1994) mudaram as características geomorfológicas e o equilíbrio crustal da região da PIAP. Tal desequilíbrio, auxiliado pela colocação de diques de diabásio, induziu ao soerguimento do Arco do Alto Paranaíba (AAP; Sgarbi et al. 2001). O período de atividade deste soerguimento pode ser inferido a partir do início das intrusões alcalinas mais antigas, que certamente foram originados a partir das anomalias mantélicas causadas por fenômenos de uplift crustal (Campos \& Dardenne 1997 a e b). Segundo Bizzi et al. (1991 e 1993), as idades Rb|Sr em flogopita variam de 117 a 119 Ma (mais antigas) e de 87 a 83 Ma (mais jovens), sugerindo assim o Eoaptiano como marco inicial da evolução do AAP.

A movimentação e os falhamentos WNW, que se manifestaram com o soerguimento do AAP, possibilitaram a sedimentação dos Grupos Areado/Mata da Corda na bacia Sanfranciscana e o alojamento de corpos alcalinos (Tapira, Araxá, Salitre, Serra Negra, Catalão I e II) e diatremas kimberlíticos (Hasui et al. 1975, Sgarbi \& Ladeira 1995, Sgarbi \& Dardenne 1997, Sgarbi et al. 1998a e b).

\subsection{A Bacia do Paraná no Oeste Mineiro}

A bacia do Paraná no oeste Mineiro é representada por seqüências não-aflorantes dos pacotes sedimentares do Grupo Paraná, Tubarão, Passa Dois e seqüências aflorantes dos Grupos São Bento e Bauru (Hasui et al., 1975), conforme apresentado na coluna estratigráfica abaixo (Tabela 01).

As unidades não aflorantes têm segmentos nordeste alcançando a PIAP, com decréscimo de espessuras e recobrimentos sucessivos do embasamento cristalino (Figura 5), onde se observa, também, a evolução paleogeográfica das Bacias do Paraná e Sanfranciscana.

O Grupo São Bento, representado pelos sedimentos da formação Botucatu e vulcânicas, com alguns sedimentos da Formação Serra Geral, cobre o conjunto paleozóico e parte dos terrenos précambrianos. Do Grupo Bauru, se acham representadas as Formações Uberaba (pacote vulcanoclástico exclusivo do Triângulo Mineiro), Marília e Itaqueri, recobrindo quase metade do Triângulo Mineiro. 
Tabela 1 - Coluna estratigráfica da bacia do Paraná no oeste mineiro (modificado de Grossi et al., 1971).

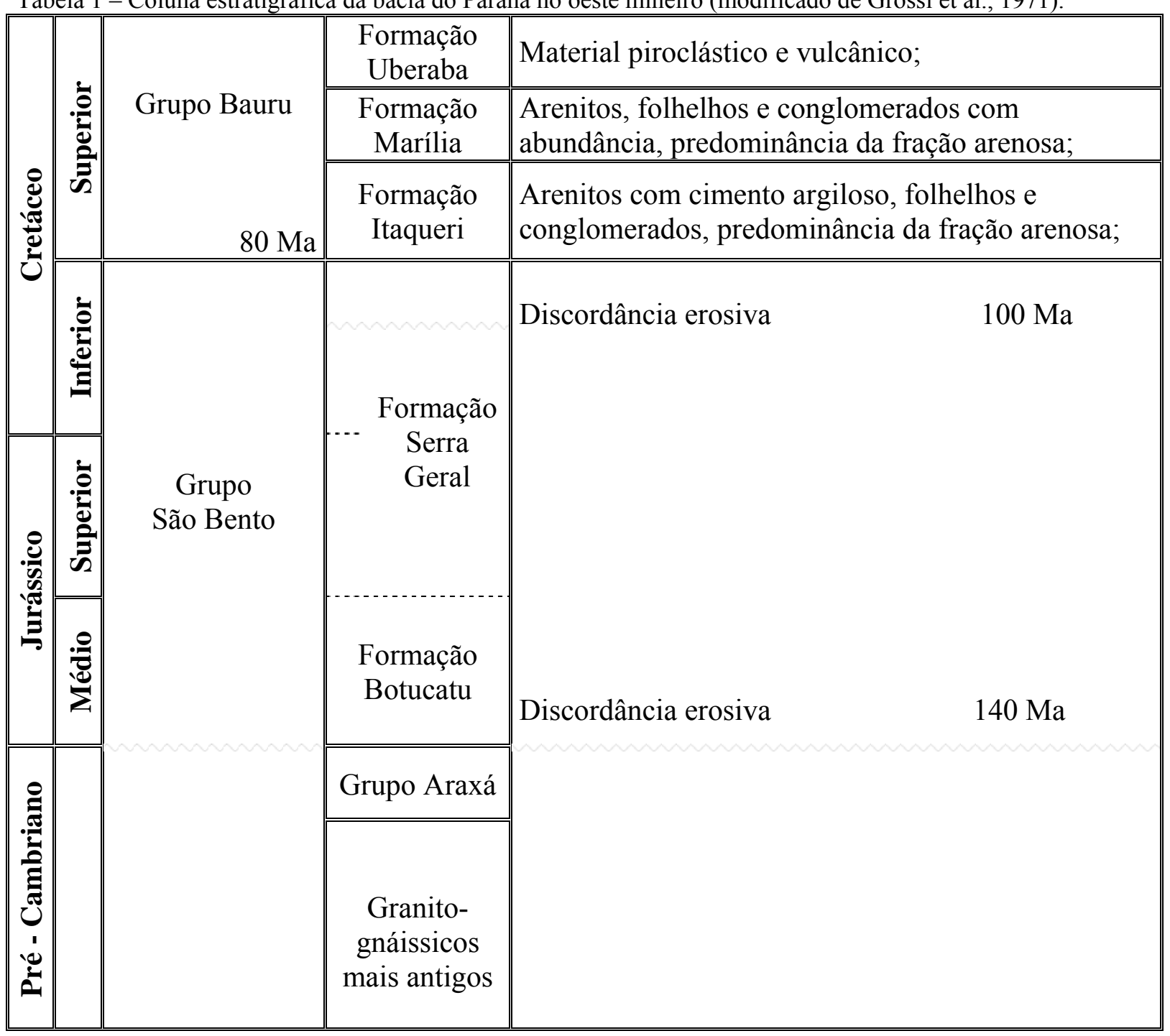

\subsection{Província Ígnea do Alto Paranaíba}

A PIAP é a província máfica potássica e alcalina mais volumosa $\left(>15.000 \mathrm{~km}^{3}\right)$ do mundo (Gibson et al 1995), comumente associada a uma zona direcional NW-SE de rochas ígneas do Cretáceo Superior. Ela se estende por $2000 \mathrm{~km}$ coincidindo com uma série de faixas móveis proterozóicas dispostas ao redor da margem norte da Bacia do Paraná (Ordoviciano a Cretáceo), no Brasil e Paraguai (Herz 1977, Almeida 1986, Almeida \& Svisero 1991), mais precisamente dentro da faixa móvel Brasília, e tanto ao lado como se sobrepondo a atual superfície do cráton arqueano do São Francisco (Almeida et al. 1980; Leonardos et al 1993).

A PIAP consiste de uma vasta variedade de corpos ígneas que incluem diques, pipes, plugs, diatremas, fluxos de lava, depósitos piroclásticos e grandes complexos plutônicos. Apresenta-se, a seguir, um breve comentário e listagem dessas ocorrências (Almeida 1983).

A. Lavas: é de longe a mais volumosa manifestação superficial do magmatismo máfico potássico da PIAP, estando presente em toda a província, de Presidente Olegário, ao norte, a São Gotardo e 
possivelmente Oliveira, ao Sul (Saadi et al. 1991), cobrindo uma área de mais de $4500 \mathrm{~km}^{2}$ (Leonardos et al. 1991). Cobrindo os sedimentos do Grupo Areado, atingem espessuras de mais de 100 m na região de Quintinos - Carmo do Paranaíba. Estão freqüentemente alteradas na forma de fértil solo amarronzado, atingindo espessura de algumas dezenas de metros, que se encontram capeadas por crosta laterítica compacta e resistente. Afloramentos frescos ocorrem em cortes recentes de estrada e escarpas dissecadas da Serra da Mata da Corda, como por exemplo em Presidente Olegário, Patos de Minas, Carmo do Paranaíba e São Gotardo.

B. Intrusões, crateras e pipes alterados: mapas aeromagnéticos mostram que centenas de anomalias dipolares estão presentes na PIAP (Bosun 1973). Algumas dessas anomalias coincidem com a superfície de rochas alcalinas intrusivas ou pipes profundamente alterados, considerados variavelmente de kimberlítos e lamproítos (Svisero et al. 1984, Barbosa 1991). Por outro lado, outras anomalias presentes especialmente na área de Coromandel, não estão associados com nenhuma rocha ígnea exposta e talvez representem atividade ígnea intrusiva desconhecida da PIAP. Exemplos de ocorrências expostas: Bocaina, Córrego do Couro e Morro Alto, Córrego Varjão, Indaiá I e II, Limeira I e II, Mata do Lenço, Pântano, Serra do Bueno e Campo Três Ranchos.

C. Complexos plutônicos: as lavas e as intrusões discutidas nos itens A e B estão espacialmente e temporalmente associadas com grandes complexos carbonatíticos (Silva et al. 1979, Gomes et al. 1990). Contudo, neste trabalho seu estudo será relegado à citação das principais ocorrências: Araxá, Catalão I e II, Salitre I e II, Serra Negra e Tapira. 


\section{Materiais e Métodos}

\subsection{Trabalho de Campo}

Os trabalhos de campo na área de estudo foram realizados em novembro de 2004.

A intrusão Indaiá I aparece, superficialmente, como solo amarronzado de topografia suave e com vegetação, de pequeno e médio porte, frondosa em meio ao ressequido serrado mineiro, cercada por blocos rolados de leucogranito cataclasado e solo claro arenoso (granulação grossa). Foram coletadas nesta intrusão quatorze amostras em canal de erosão recente (voçoroca), cerca de 1,5 metro abaixo da linha de superfície, em provável divisor de águas, sendo as amostras identificadas pelos prefixos IN 01 a IN 14. Já a intrusão Indaiá II, localizada a cerca de 50 metros a noroeste da intrusão Indaiá I, destaca-se como um pequeno morrote, cercado por vegetação, também de pequeno a médio porte, mais exuberante que a observada na intrusão Indaiá I. O morrote apresenta uma cobertura de solo de alteração, salpicado por blocos cinzentos bastante densos, bordejados por vegetação rasteira e singelas flores amarelas. A partir destes blocos foram coletas outras quatorze amostras identificadas pelos prefixos IN 15 a IN 28.

A disposição espacial das amostras coletadas é apresentada na Figura 2.

\subsection{Localização e Acessos}

As intrusões Indaiá I (240634/7944952) e Indaiá II (240772/7945034) encontram-se próximas de uma estrada vicinal (2438812/7943703) que parte da rodovia MG - 190, ligando as vilas de Monte Carmelo e Abadia dos Dourados em Minas Gerais. O mapa com a localização dos principais acessos e intrusões encontra-se na Figura 7.

\subsection{Trabalhos de Laboratório}

Com base em características macroscópicas das amostras coletadas nas intrusões Indaiá I e Indaiá II, tais como heterogeneidades e/ou homogeneidades texturais, estruturas e presença de nódulos mantélicos, foram selecionadas as mais representativas para a preparação de lâminas petrográficas. Os critérios para orientação do corte, por vezes 02,03 ou 04 seções na mesma amostra, seguiram obedecendo o grau de alteração da rocha e tamanho e frequência dos nódulos. A confecção das lâminas, foram realizados nos laboratórios do Instituto de Geociências da Universidade de São Paulo (IGc-USP). 


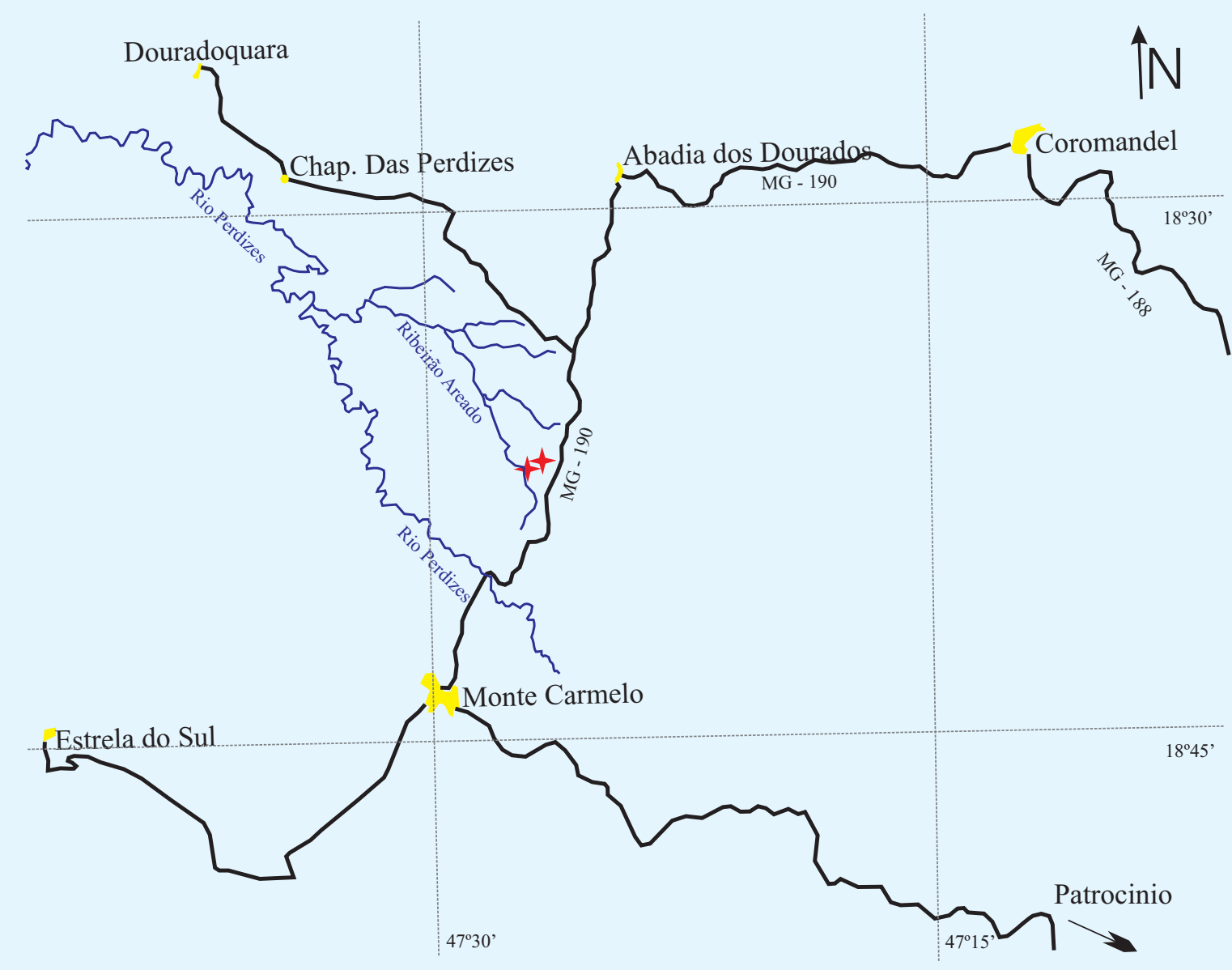

\section{Escala 1:100.000}

Cidade

$+^{+}$Intrusões estudadas

2 Estradas pavimentadas

?

Figura 7. Mapa de localização com as principais vias de acesso à área das intrusões estudadas. 
As descrições petrográficas obtidas a partir das seções foram realizadas nos laboratórios de microscopia petrográfica do Instituto, utilizando-se microscópio binocular Olympus BXP - 50 com luz transmitida e refletida.

A etapa final de petrografia culminou com a seleção de 06 amostras representativas para a confecção de seções delgadas polidas para fins de análise com microssonda eletrônica.

\subsection{Química Mineral}

A caracterização química dos principais minerais das rochas em questão (olivina, piroxênio, flogopita, ilmenita, espinélio, perovskita) foi realizada com o auxílio de microssonda eletrônica.

As determinações foram efetuadas no Laboratório de Microssonda Eletrônica do Departamento de Mineralogia e Geotectônica do IGc - USP, empregando-se um instrumental de fabricação JEOL modelo JXA - 8600S, equipado com cinco espectrômetros dispersivos (WDS) acoplados com os seguintes pares de cristais: TAP/STE, TAP/PET, LIF/PET, PET/LIF, LIF/PET. O equipamento encontra-se automatizado com um sistema Voyager 3.6.1 da NORAN Instruments. As determinações efetuaram-se as em seções delgadas polidas, metalizadas a vácuo com película de carbono ( $25 \mathrm{~nm})$ em evaporador AUTO 206 da EDWARDS.

As condições analíticas de rotina adotada nos trabalhos com microssonda eletrônica, encontram-se a seguir (Tabela 02).

Tabela 2 - Condições Analíticas da microssonda eletrônica para os minerais.

\begin{tabular}{||c|c||c|}
\hline \multirow{4}{*}{ SILICATOS } & Voltagem & $15 \mathrm{kV}$ \\
\cline { 2 - 3 } & Corrente de análise & $20.10 \pm 0,10 \mathrm{nA}$ \\
\cline { 2 - 3 } & Diâmetro do feixe & $5 \mu \mathrm{m}$ \\
\hline \hline \multirow{3}{*}{ PEROVSKITA } & Voltagem & $25 \mathrm{kV}$ \\
\cline { 2 - 3 } & Corrente de análise & $50.10 \pm 0,10 \mathrm{nA}$ \\
\cline { 2 - 3 } & Diâmetro do feixe & $1 \mu \mathrm{m}$ \\
\hline
\end{tabular}

Os tempos máximos de integração das contagens de pulsos nos contadores variam de 10" para Ca e Si até 50". As correções para o efeito matriz (Z, número atômico; A, absorção de massa; e F, fluorescência secundária) foram conduzidas pelo programa PROZA, de uso interno do laboratório. A exatidão dos resultados obtidos, que varia com a concentração do elemento determinado em cada fase investigada, apresenta erros de 1 a $2 \%$ para os elementos maiores, $5 \%$ para os menores e superiores a $10 \%$ para os traços (> $1 \%$ em peso do elemento).

Com o objetivo de avaliar o grau de homogeneidade do mineral, foram efetuadas, quando possível, leituras de pontos nas bordas e nos centros dos cristais, sendo os resultados apresentados na forma de tabelas e diagramas. 
Os resultados de química mineral são apresentados na forma de porcentagem em peso de óxidos, bem como expressos em proporções catiônicas, fórmulas químicas estruturais, componentes moleculares ou mesmo diagramas de variação química, usando-se para este último propósito os programas Corew Draw ${ }^{\circledR}$ 11, Microsoft Word ${ }^{\circledR}$ e Excel ${ }^{\circledR}($ Office XP).

O cálculo das fórmulas estruturais seguiu as recomendações de Deer et al. (1992), sendo os cristais de olivina calculados na base de 4 átomos de oxigênio e classificados a partir dos componentes moleculares forsterita $\left(\mathrm{Mg}_{2} \mathrm{SiO}_{4}\right)$ e faialita $\left(\mathrm{Fe}_{2} \mathrm{SiO}_{4}\right)$, os cristais de ilmenita e piroxênio de 6 átomos de oxigênio e os cristais de espinélio na base de 32 oxigênios.

A proporção de $\mathrm{Fe}^{3+} / \mathrm{Fe}^{2+}$ foi calculada a partir da fórmula de Droop (1987), definida por $\mathrm{F}=$ $2 *(1-\mathrm{T} / \mathrm{S})$, onde $\mathrm{F}$ é o número de íons $\mathrm{Fe}^{3+}$ presentes por $\mathrm{X}$ átomos de oxigênio na fórmula do mineral; $\mathrm{T}$ é o número ideal de cátions por unidade de fórmula e $\mathrm{S}$ o total de cátions observados por $\mathrm{X}$ átomos de oxigênio. Este cálculo somente pode ser utilizado respeitadas as seguintes premissas: ferro é o único elemento presente com diferentes valências, oxigênio é o único ânion, e inexistência de sítios estruturais vagos ou com proporção de elemento não analisado. Para os opacos (ilmenita) em conformidade com o método de Carmichael (1974).

Para o cálculo da fórmula química geral dos piroxênios seguiu-se as recomendações de

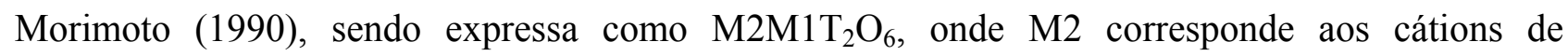
coordenação octaédrica, geralmente distorcida; M1 aos cátions de coordenação octaédrica regular; e $\mathrm{T}$ aos cátions de coordenação tetraédrica. A distribuição dos componentes moleculares em membros finais seguiu-se a metodologia de Cawthorm \& Collerson (1974), em que eles são calculados na seguinte ordem: Jd - jadeíta $\left(\mathrm{NaAlSi}_{2} \mathrm{O}_{6}\right)$; Ae - egirina $\left(\mathrm{Na}, \mathrm{K}, \mathrm{Fe}^{3+} \mathrm{Cr}, \mathrm{Si}_{2} \mathrm{O}_{6}\right)$; es - essenita $\left(\mathrm{CaFe}^{3+} \mathrm{Al}^{\mathrm{IV}} \mathrm{SiO}_{6}\right)$; CaTiTS - cálcio-titano tshermakita $\left(\mathrm{CaAl}^{\mathrm{VI}} \mathrm{Al}^{\mathrm{IV}} \mathrm{SiO}_{6}\right)$; CaTS - cálciotchermakita, Wo - wollastonita $\left(\mathrm{Ca}_{2} \mathrm{Si}_{2} \mathrm{O}_{6}\right)$; En - enstatita $\left(\mathrm{Mg}_{2} \mathrm{Si}_{2} \mathrm{O}_{6}\right)$ e Fs - ferrossilita $\left(\mathrm{Fe}^{2+} \mathrm{Si}_{2} \mathrm{O}_{6}\right)$.

Essa classificação obedece as recomendações da IMA (International Mineralogical Association), inclusive quanto ao emprego dos adjetivos modificadores para expressar quantidades incomuns de cátions. 


\section{Petrografia}

\subsection{Intrusão Indaiá I}

Na intrusão Indaiá I, as rochas são relativamente homogêneas, apresentando coloração cinzaescuro em amostras frescas e levemente amarronzadas nas superfícies em contato com as intempéries. São rochas porfiríticas, devido à onipresença de megacristais (alguns xenocristais) milimétricos $(0,5$ a $04 \mathrm{~mm})$ e fenocristais anédricos a subédricos de olivina, opacos e mais raramente de piroxênios, imersos em matriz de granulação afanítica. Esses megacristais, fenocristais e xenocristais são abundantes,representando de 35 a $50 \%$ em volume.

Xenólitos milimétricos a centimétricos $(02$ a $30 \mathrm{~mm})$, na maioria das vezes arredondados a elípticos, esverdeados, são representados por litotipos dunítico, piroxenítico, carbonático e "lapilli”.

Sob a ação de $\mathrm{HCl} 10 \%$ a frio, as amostras apresentam efervescência, principalmente na matriz, nos xenólitos carbonáticos e em lapilli. Sinais evidentes de fluxo ou orientação dos mega e fenocristais e de xenólitos não foram observados.

Foram realizadas 30 (trinta) seções delgadas, posicionadas de forma a obter diferentes materiais, seja megacristais ou xenólitos. Ao microscópio, a rocha apresenta textura porfirítica seriada, caracterizada por uma distribuição aleatória de megacristais, fenocristais e xenólitos, fixados na matriz fina (Figuras $8 \mathrm{~A}, 8 \mathrm{~B}$ e $8 \mathrm{C}$ ).

A matriz, representando cerca de $40 \%$ do volume da rocha, é formada por diminutos cristais anédricos de olivina ( $06 \%$ em volume) e minerais opacos $(10 \%)$, monticellita tabular ( $\sim 05 \%)$ com diâmetro entre 0,1 e $3 \mathrm{~mm}$ (Figura $8 \mathrm{D}$ ), cristais amarronzados subédricos de perovskita (03\%) com até 0,2 mm (Figura 9A), clinopiroxênio (diopsídio) esverdeado (04\%) e carbonatos (12\%) (Figuras 9B e 9C).

Imersos na matriz, megacristais, fenocristais e microfenocristais de olivina apresentam dimensões variáveis entre $0,5 \mathrm{~mm}$ e $2 \mathrm{~cm}$, perfazendo cerca de $24 \%$ do volume da rocha. Comumente são bordejados por (Figura 9D e 10A). Sinais de absorção (por exemplo, bordas corroídas) e zonação (Figuras 10B, 10C e 10D) são também observados.

Fenocristais e microfenocristais comumente anédricos e aglomerados de minerais opacos, com diâmetros entre 0,1 a $5 \mathrm{~mm}$, perfazem cerca de $15 \%$ do volume da rocha, (Figuras 11A e 11B). Sob luz refletida, exibem exsolução de fino intercrescimento de dois minerais (Figura 11C). 


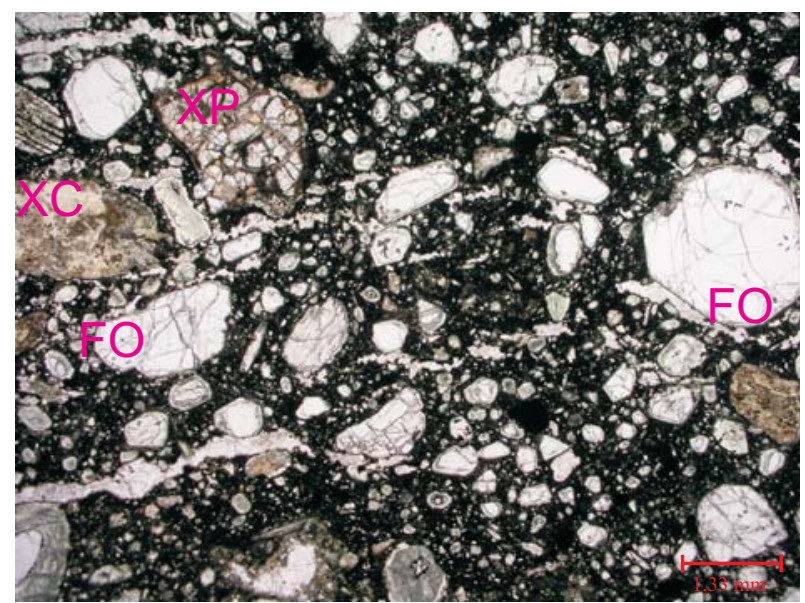

Figura 8B. Fotomicrografia da rocha da intrusão Indaiá I. Textura porfirítica seriada da rocha, com destaque para: fenocristal de olivina (FO); melilita alterada (M). Polarizadores descruzados. Amostra 11D2.

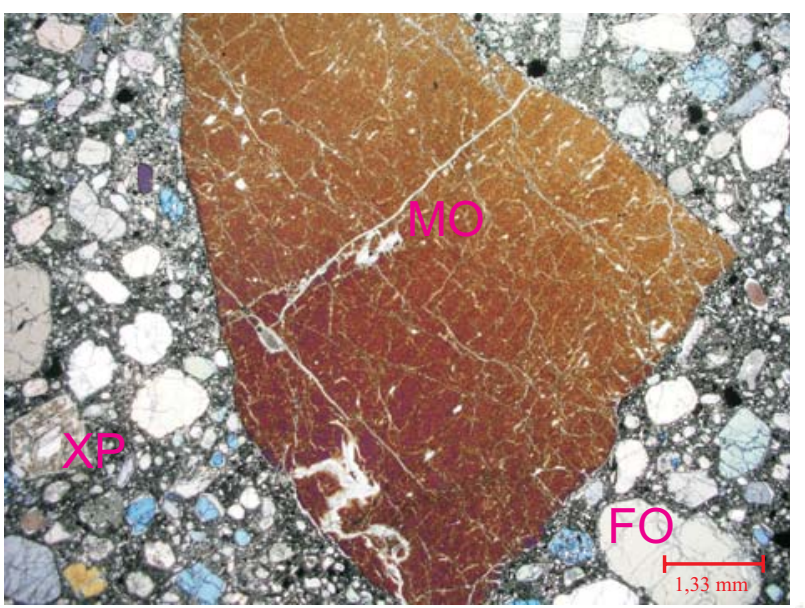

Figura 8A. Fotomicrografia da rocha da intrusão Indaiá I. Textura porfirítica seriada da rocha, com destaque para xenólito piroxenítico(XP); xenólito carbonatítico (XC); fenocristal de olivina (FO). Polarizadores descruzados. Amostra 11B 1.

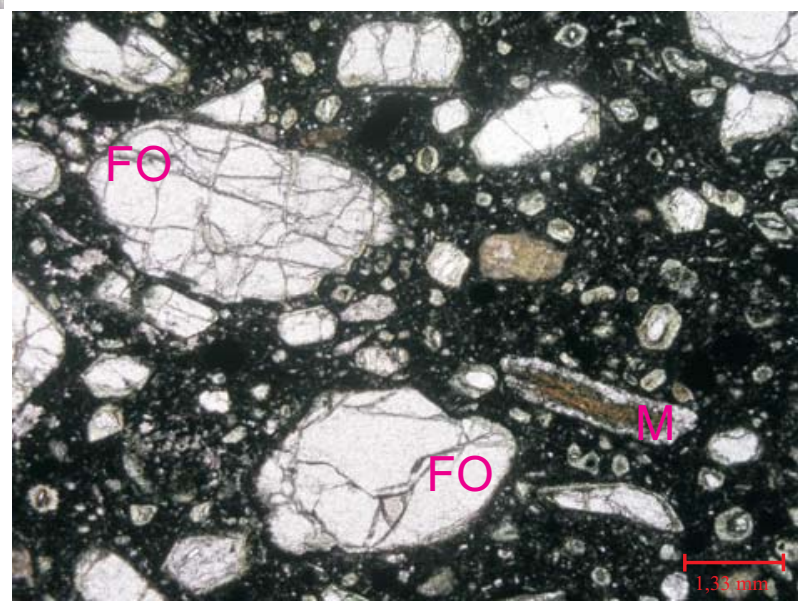

Figura 8C - Fotomicrografia da rocha da intrusão Indaiá I. Textura porfirítica seriada da rocha, com destaque para: xenólito piroxenítico (XP); fenocristal de olivina (FO); macrocristal de olivina (MO). Polarizadores cruzados. Amostra 01B A.

Figura 8D. Fotomicrografia da rocha da intrusão Indaiá I. Destaque para os componentes da matriz: cristais de olivina $(\mathrm{O})$, opacos $(\mathrm{OP})$, carbonatos $(\mathrm{C})$, monticelita $(\mathrm{MON})$ e perovskita $(\mathrm{P})$. Polarizadores descruzados. Amostra 11B1.

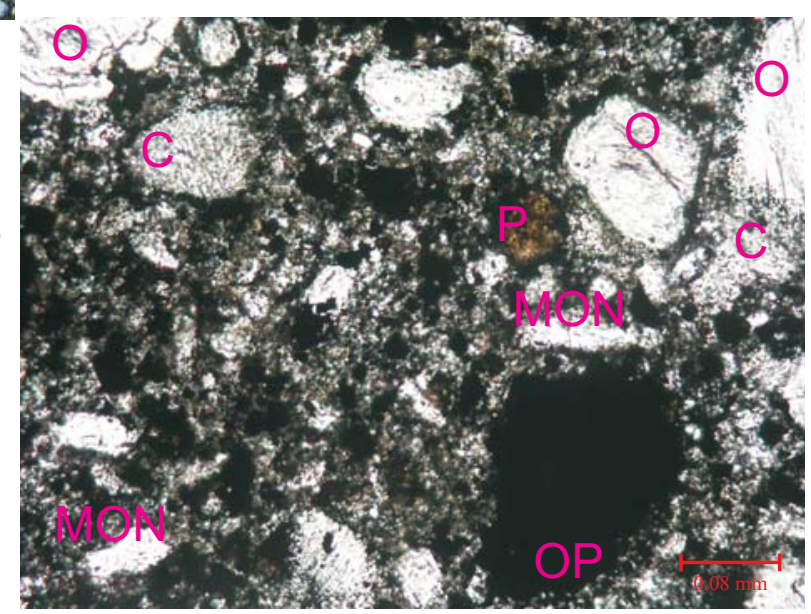




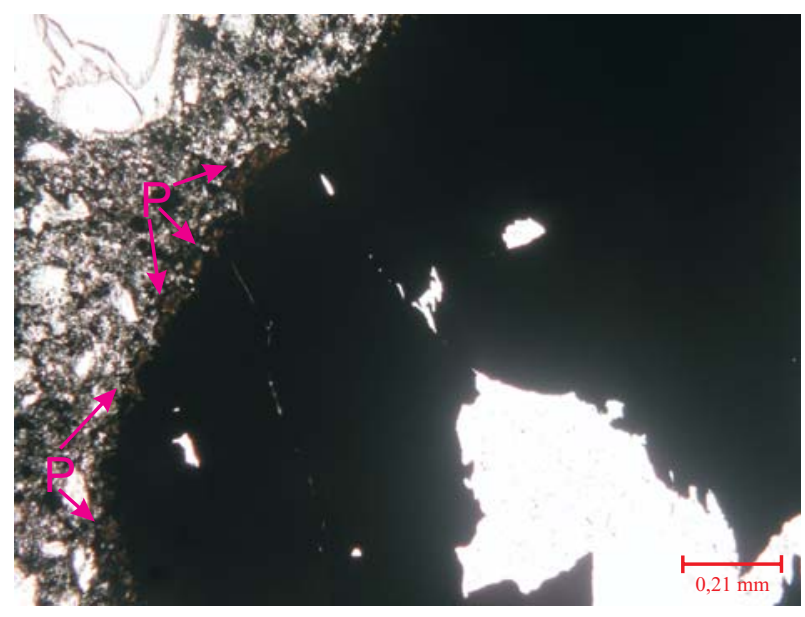

Figura 9A. Fotomicrografia da rocha da intrusão Indaiá I. Cristais de perovskita $(\mathrm{P})$ em borda de mineral opaco. Polarizadores descruzados. Amostra 08B2.

Figura 9B. Fotomicrografia da rocha da intrusão Indaiá I. Destaque para os componentes da matriz: clinopiroxênio (diopsidio) esverdeado (D), carbonato esbranquiçado (C), agregado de opacos e perovskitas. Polarizadores descruzados. Amostra $02 \mathrm{~A}$.
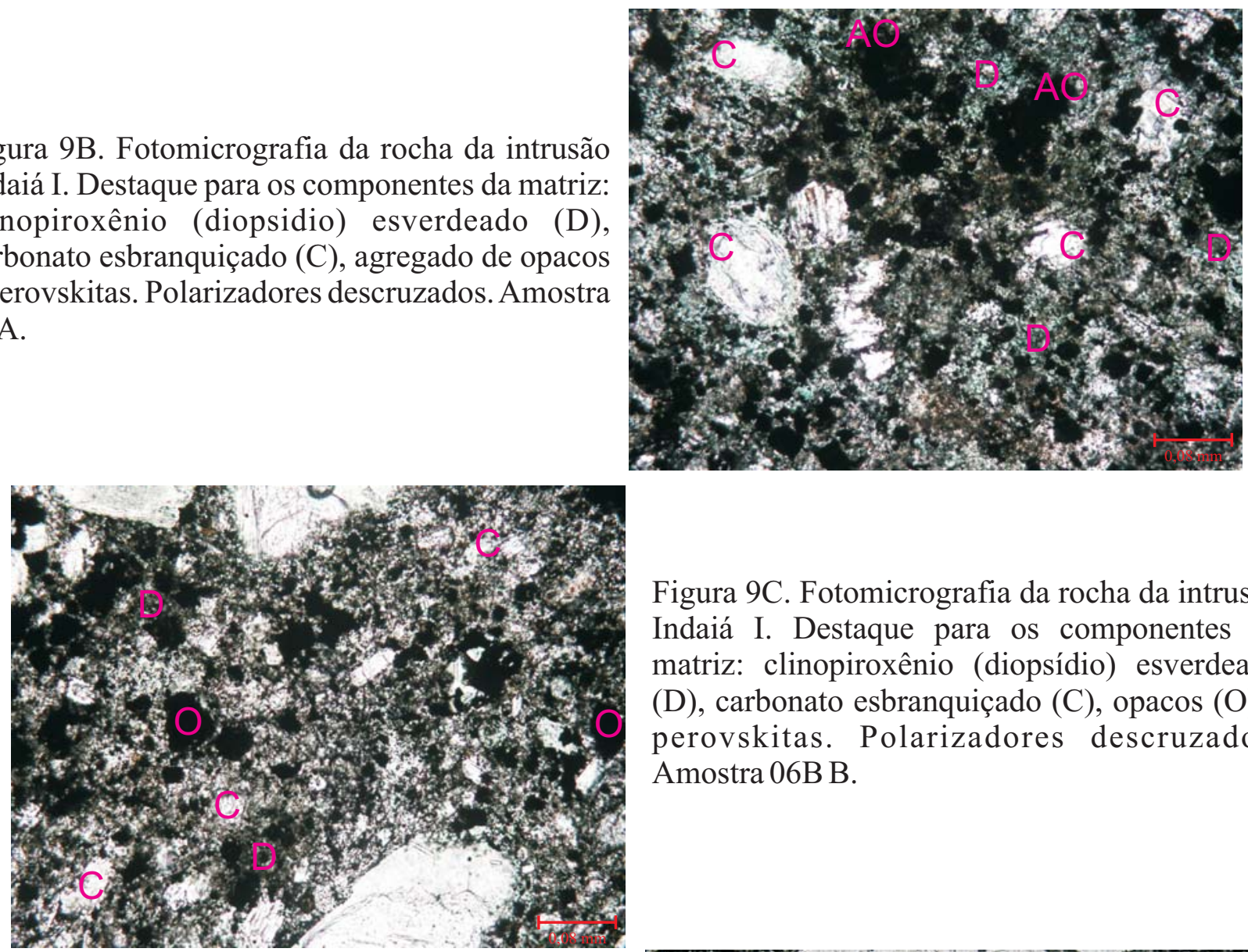

Figura 9C. Fotomicrografia da rocha da intrusão Indaiá I. Destaque para os componentes da matriz: clinopiroxênio (diopsídio) esverdeado (D), carbonato esbranquiçado (C), opacos (O) e perovskitas. Polarizadores descruzados. Amostra 06B B.

Figura 9D. Fotomicrografia da rocha da intrusão Indaiá I. Fenocristais e cristais de olivina $(\mathrm{O})$ bordejada por bowlingita (B). Polarizadores descruzados. Amostra 02C (A).

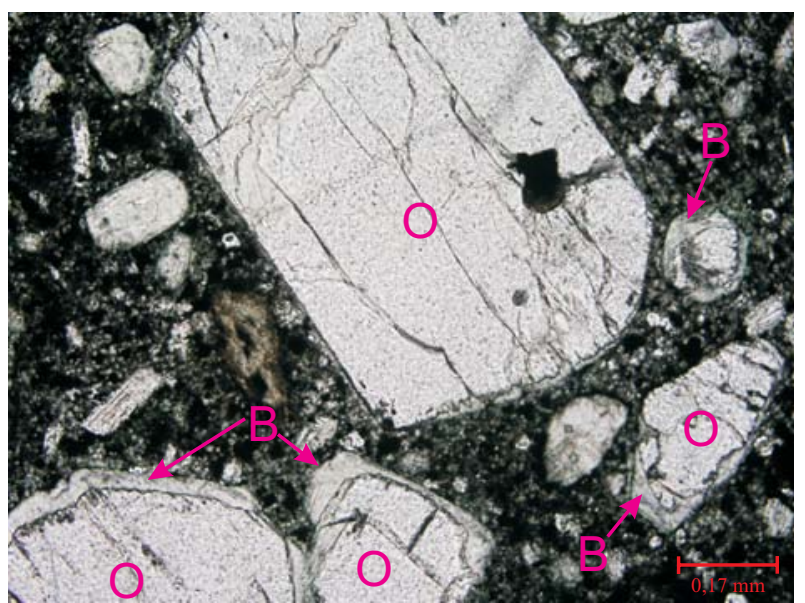




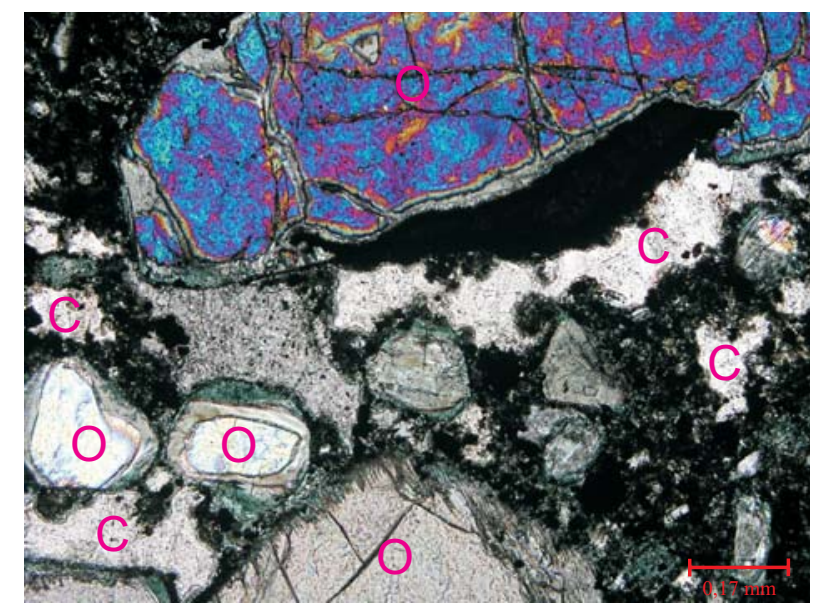

Figura 10A. Fotomicrografia da rocha da intrusão Indaiá I. Cristais de olivina $(\mathrm{O})$ bordejada por bowlingita (cinza) e clorofaeita (esverdeadas). Polarizadores cruzados. Amostra 11B2.

Figura 10B. Fotomicrografia da rocha da intrusão Indaiá I. Fenocristais de olivina zonados. Polarizadores cruzados. Amostra 4A1.
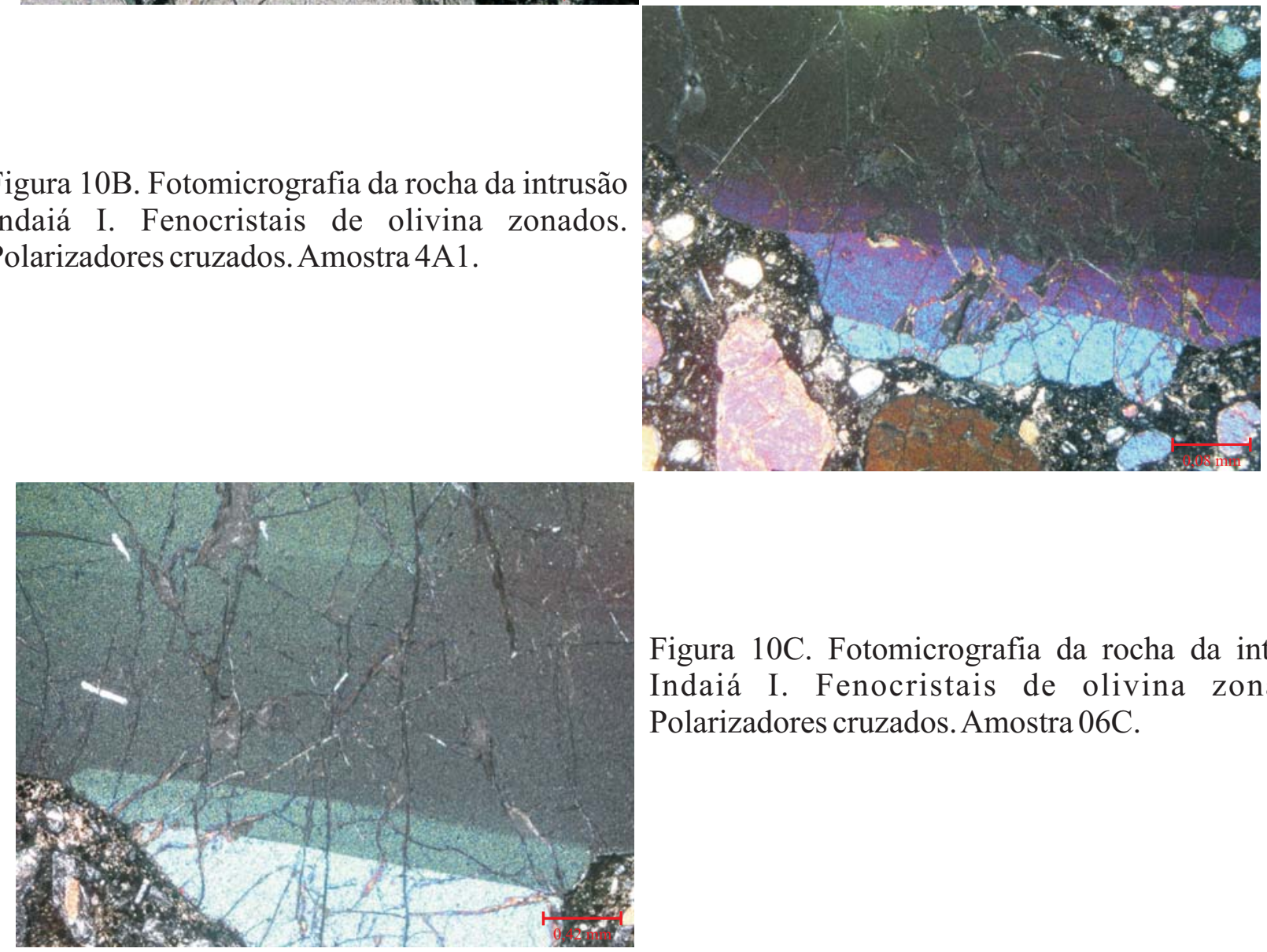

Figura 10C. Fotomicrografia da rocha da intrusão Indaiá I. Fenocristais de olivina zonados. Polarizadores cruzados. Amostra 06C.

Figura 10D. Fotomicrografia da rocha da intrusão Indaiá I. Fenocristais de olivina zonados. Polarizadores cruzados. Amostra 11D2.

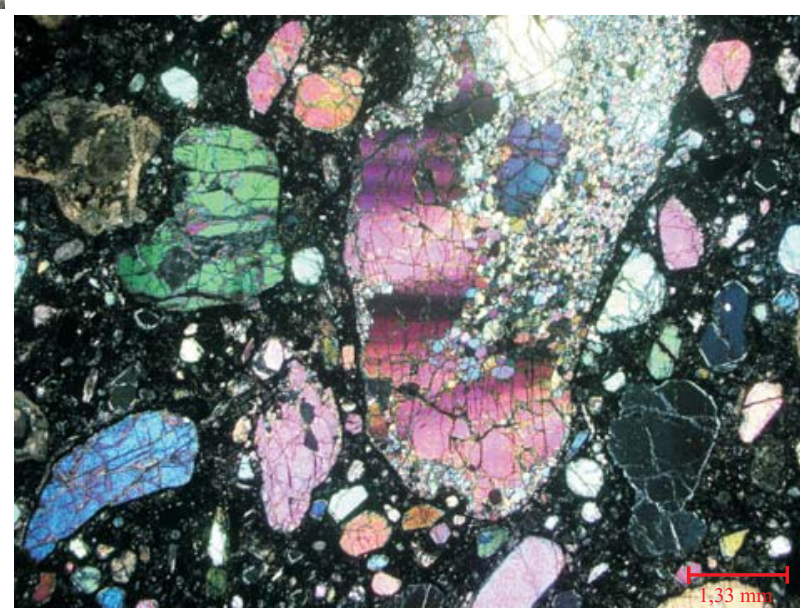


Microfenocristais de melilita representam cerca de 5\% do volume. Alteram-se em carbonatos (bordas) e minerais micáceos, comumente biotita (núcleos). Em diversos grãos são observados sinais de reabsorção e incipiente deformação (Figuras 11D e 12A).

Os raros fenocristais de ortopiroxênio registrados pertencem ao grupo da enstatita ferrossilita, tendendo ao vértice da enstatita devido à cor característica acastanhada e pequeno atraso $(\sim 20 \mathrm{m \mu})$. Apresentam diâmetro variando entre 5 e 8,5 $\mathrm{mm}$ e são capeados por borda quelifitizada (Figuras 12B e 12C).

\subsection{Intrusão Indaiá II}

As rochas da intrusão Indaiá II são, também, macroscopicamente homogêneas, apresentando coloração cinza em amostras frescas, sendo levemente amarronzadas com manchas esbranquiçadas em superfícies expostas às intempéries. São rochas porfiríticas devido à presença de dispersos fenocristais milimétricos $(0,5$ a $2 \mathrm{~mm})$, anédricos a subédricos, comumente de olivina, fixados em matriz de granulação afanítica. Xenólitos afaníticos, de coloração mais clara ou escura que a matriz da rocha são abundantes. Apresentam tamanho milimétrico $(0,5$ a $8 \mathrm{~mm})$ e comumente são estirados e com bordas irregulares. São observados evidentes sinais de fluxo ou orientação de fenocristais e xenólitos. Ao todo, os fenocristais e xenólitos presentes perfazem no máximo 45\% do volume. Sob a ação de $\mathrm{HCl} 10 \%$ a frio, as rochas não efervescem, sejam os fenocristais e xenólitos ou a matriz.

Foram realizadas vinte e cinco seções delgadas, posicionadas de forma a obter diferentes materiais (fenocristais e xenólitos). Ao microscópio, a rocha que compõe a intrusão é relativamente homogênea, a não ser pela distribuição aleatória dos fenocristais e xenólitos que estão fixados matriz fina (Figuras 12D e 13A). 


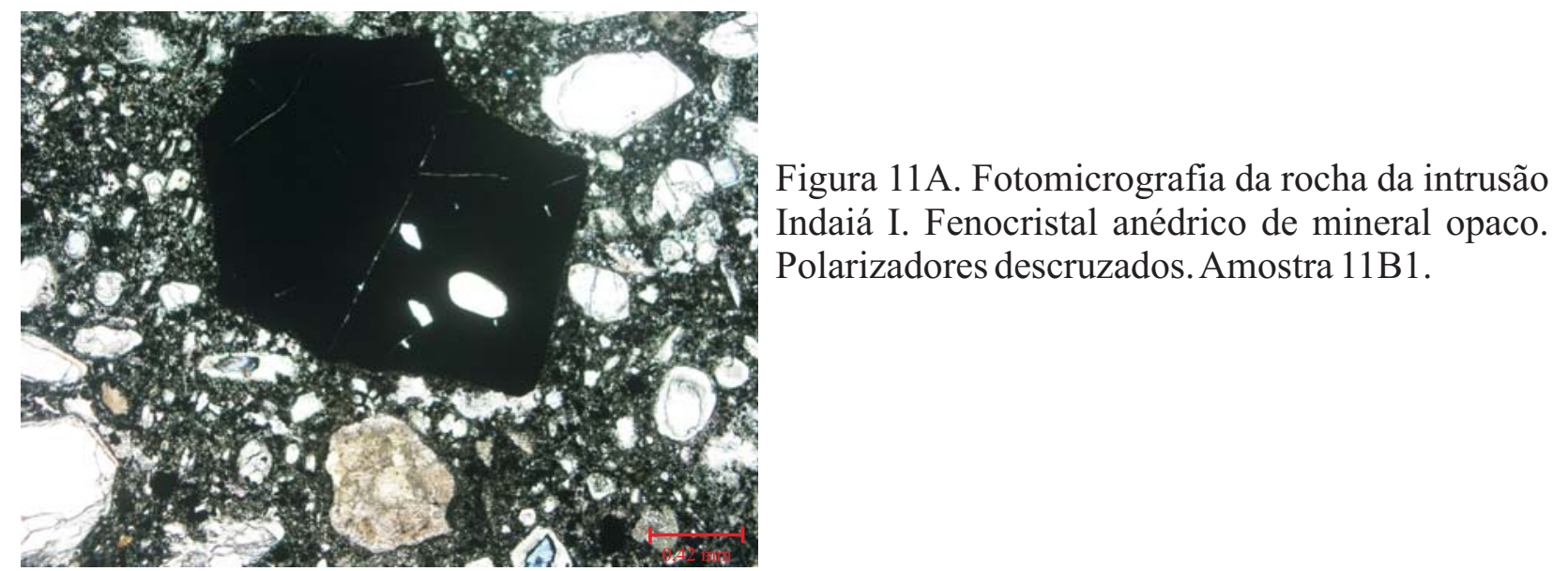

Figura 11B. Fotomicrografia da rocha da intrusão Indaiá I. Aglomerado composto por cristais minerais opacos e perovskita. Polarizadores descruzados. Amostra 06BA.
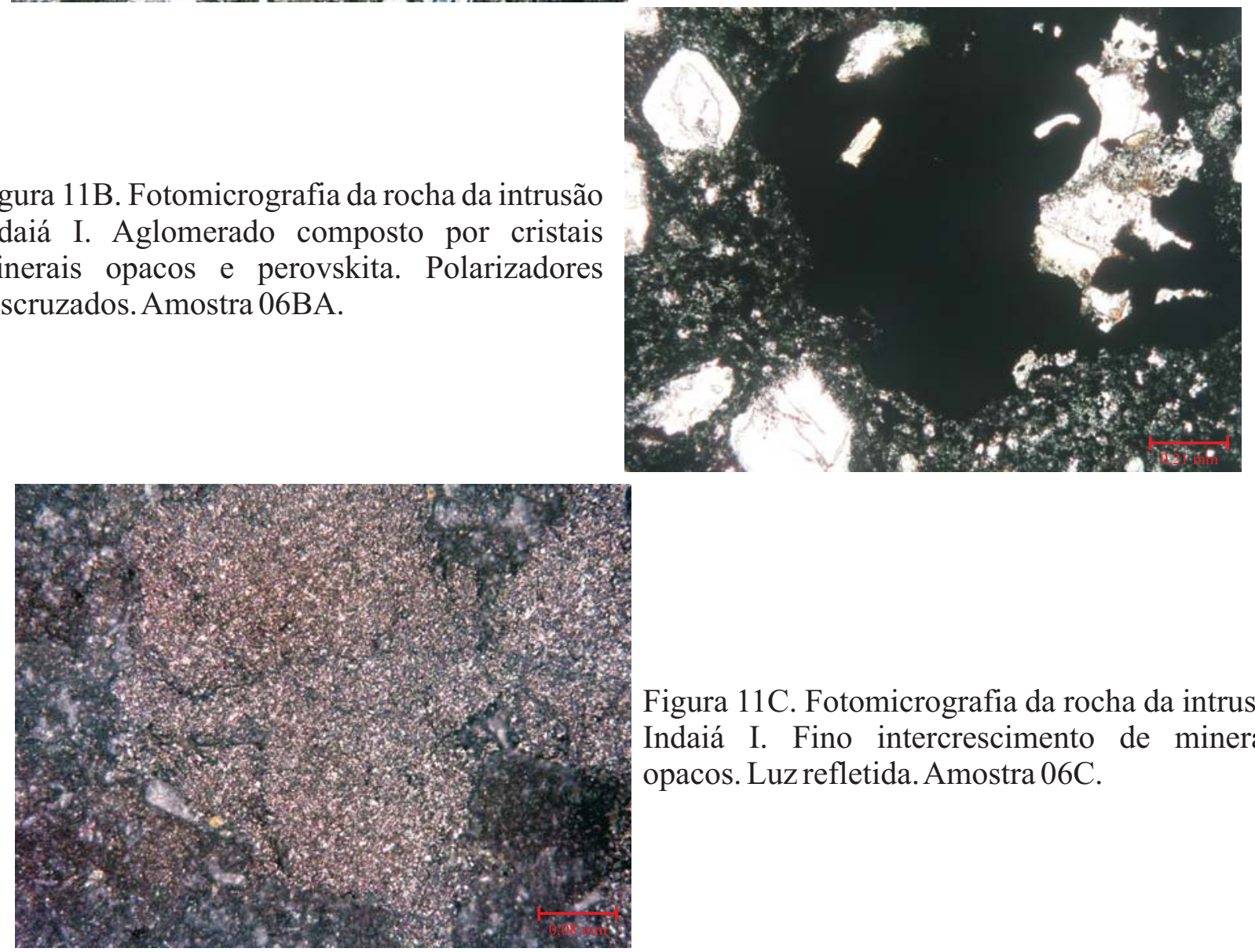

Figura 11C. Fotomicrografia da rocha da intrusão Indaiá I. Fino intercrescimento de minerais opacos. Luz refletida. Amostra 06C.

Figura 11D. Fotomicrografia da rocha da intrusão Indaiá I. Microfenocristais de melilita (M), alterado e deformados. Polarizadores cruzados. Amostra 02A.

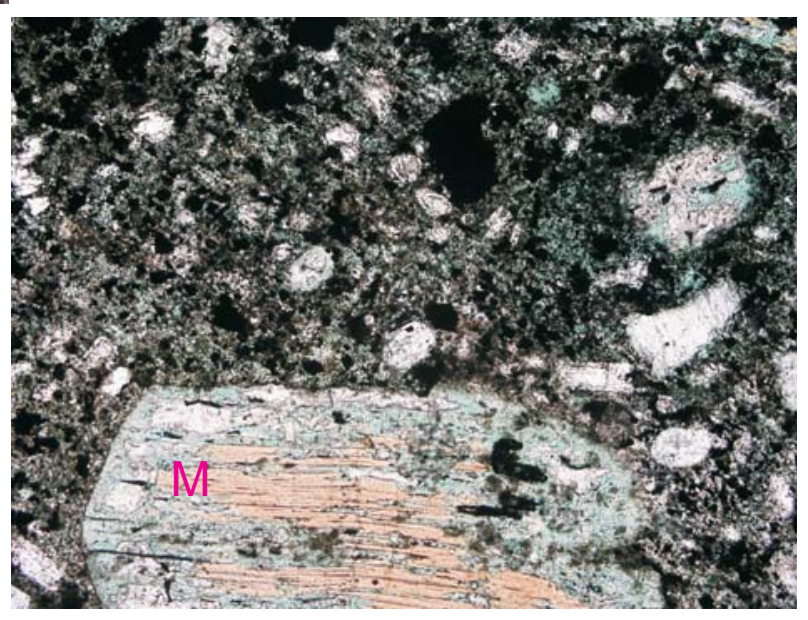




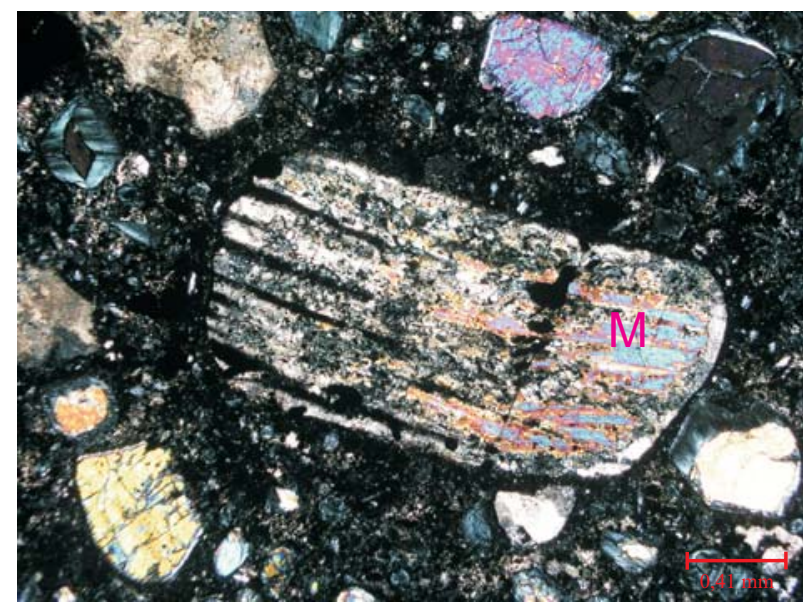

Figura 12A. Fotomicrografia da rocha da intrusão Indaiá I. Microfenocristais de melilita (M), alterado e deformado. Polarizadores cruzados. Amostra 11B1.

Figura 12B. Fotomicrografia da rocha da intrusão Indaiá I. Macrocristais de ortopiroxênio (enstatita - ferrossilita) com borda quelifitizada. Polarizadores descruzados. Amostra 04A1.
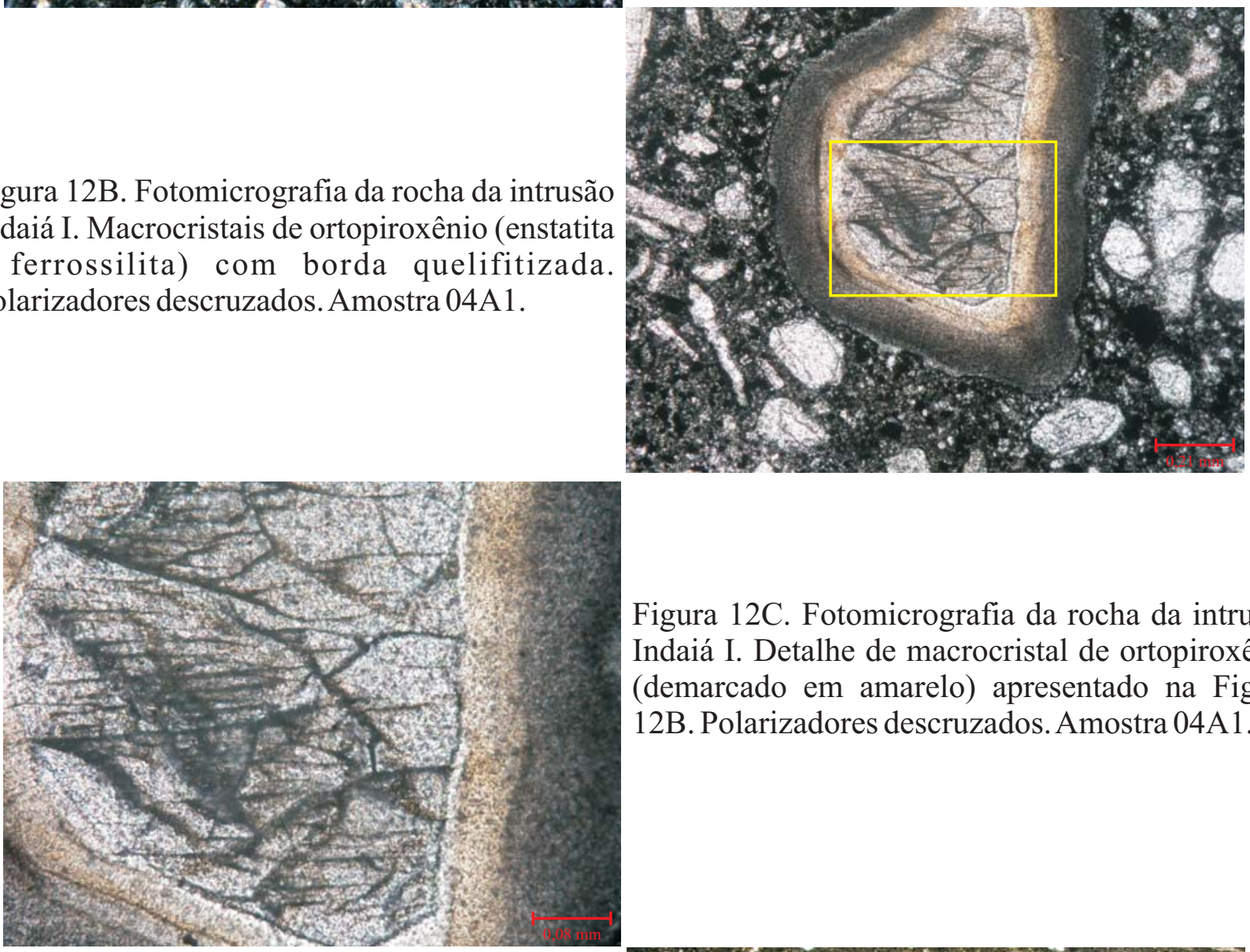

Figura 12C. Fotomicrografia da rocha da intrusão Indaiá I. Detalhe de macrocristal de ortopiroxênio (demarcado em amarelo) apresentado na Figura 12B. Polarizadores descruzados. Amostra 04A1.

Figura 12D. Fotomicrografia da rocha da intrusão Indaiá II. Textura porfirítica, com fenocristais de olivina. Observe os xenólitos estirados (XE). Polarizadores descruzados. Amostra 28A.

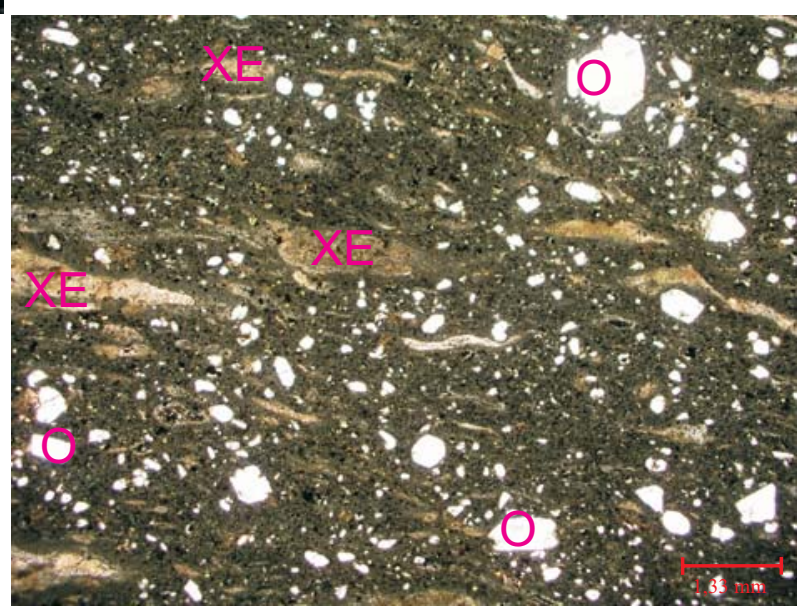


A matriz representa cerca de 55\% do volume da rocha (Figuras 13B e 13C). Compõe-se de complexa assembléia mineral, contendo alguns microfenocristais prismáticos a subédricos de clinopiroxênio diopsídico esverdeado (30\%), às vezes levemente alterado para mineral amarelado/azulado, cristais anédricos de minerais opacos (10\%), comumente associados a espinélio avermelhado, cristais subédricos a anédricos de perovskita (10\%) e grãos arredondados de olivina (5\%). Além disso, ocorre também raro vidro intersticial, embora já devidrificado.

Imersos na matriz, os cristais de olivina perfazem cerca de $10 \%$ do volume da rocha. Ocorrem na forma de macrocristais (dimensões entre $0,8 \mathrm{~mm}$ e $1 \mathrm{~cm}$; Figura 13D) e de fenocristais (Figura 14A), apresentando sinais de reabsorção evidenciado por bordas corroídas e/ou texturas de embayament (Figura 14B).

Microfenocristais de minerais opacos (diâmetro variando entre 0,1 e 0,5 mm) são também observados, perfazendo cerca de 5\% do volume da rocha. Encontram-se comumente associados a cristais anédricos de espinélio avermelhados e perovskita (Figuras 14C, 14D e 15A).

Além disso, são observados três tipos de microvenulações dispersas pela matriz, perfazendo cerca de $04 \%$ da rocha. O primeiro (Figura 15B) é representado pelas venulações que apresentam cristais tabulares de richterita alaranjada e cristais de minerais opacos, sendo preenchida por um agregado de mineral incolor a levemente amarelado, com extinção ondulada. No segundo (Figuras 15C e 15D), microvenulações de vidro parcialmente devidrificado percolam cristais prismáticos de diopsídio incolor. Já no terceiro tipo (Figuras 15D e 16A), também associadas a diopsídios incolor, compõe-se de um mineral amarelo pálido (scherbakovita?).

\subsection{Xenólitos}

O estudo petrográfico detalhado de xenólitos é de grande importância, principalmente os nódulos de origem mantélica, considerando que eles registram informações imprescindíveis para promover novas discussões sobre a natureza e as condições subcrustais, na região onde foram gerados os magmas dessas intrusões em rápida ascensão. Nesse sentido, serão apresentadas as descrições petrograficas dos xenólitos observados nas intrusões Indaiá - I e II.

\subsubsection{Intrusão Indaiá I}

Os xenólitos observados nesta intrusão perfazem cerca de $15 \%$ do volume da rocha, sendo representados pelas seguintes variedades petrográficas. 


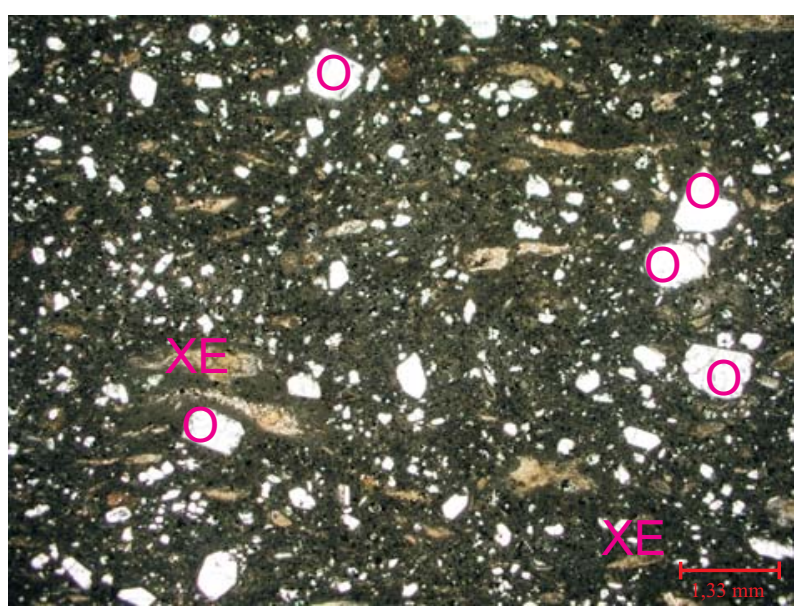

Figura 13B. Fotomicrografia de rocha da intrusão II. Matriz com diopsídio, opacos (OP), perovskita (P) e olivina (O). Amostra 21A.

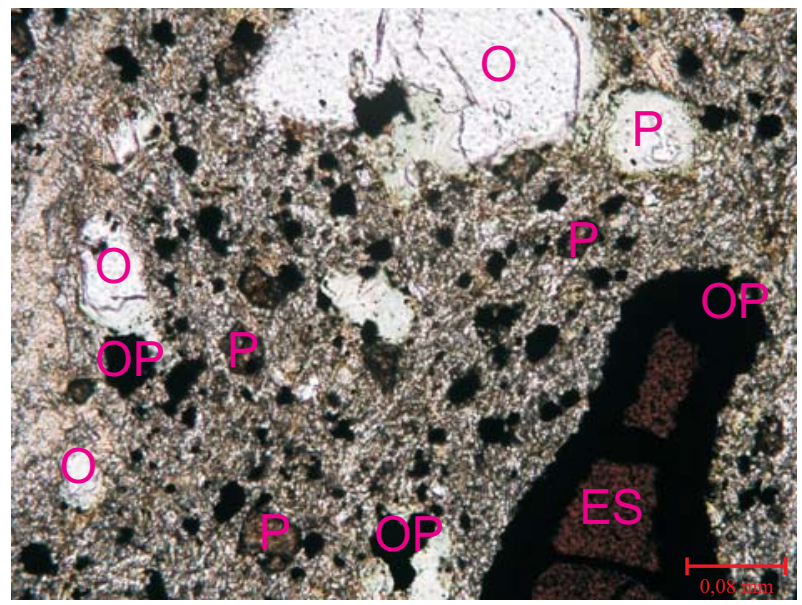

Figura 13D. Fotomicrografia de rocha da intrusão II. Macrocristal de olivina com bordas corroídas. Polarizadores descruzados. Amostra 28A.
Figura 13A. Fotomicrografia de rocha da intrusão II. Textura porfirítica, com fenocristal de olivina. Observem-se os xenólitos estirados (XE). Polarizadores descruzados. Amostra 25A.

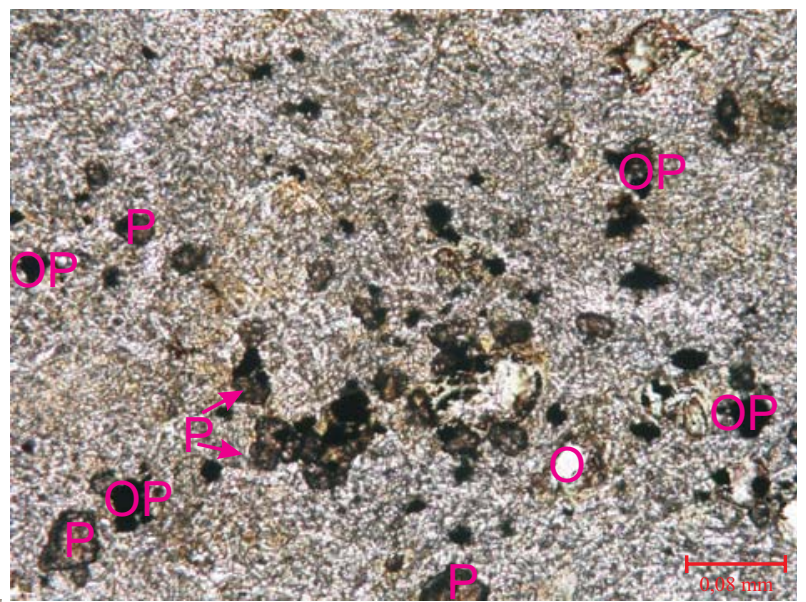

Figura 13C. Fotomicrografia de rocha da intrusão II. Matriz com diopsídio, opacos (OP), perovskita (P) e olivina $(\mathrm{O})$. Observe macrocristais de espinélio (ES). Polarizadores descruzados. Amostra 24A(A).

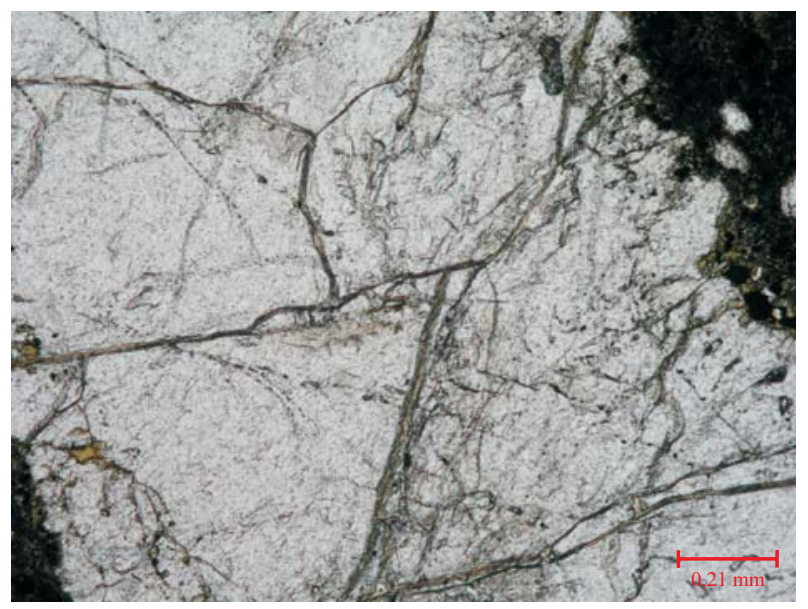




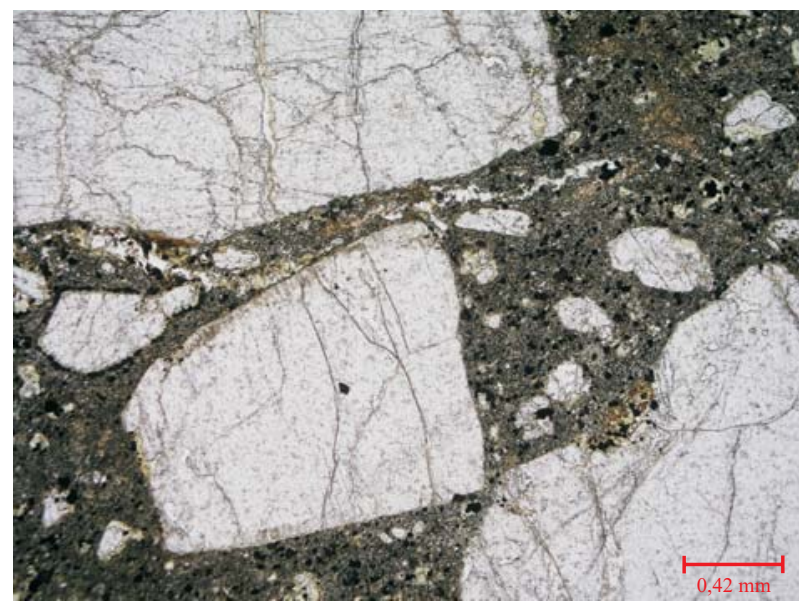

Figura 14A. Fotomicrografia de rocha da intrusão II. Fenocristais anédricos de olivina. Polarizadores descruzados. Amostra 21A.

Figura 14B. Fotomicrografia de rocha da intrusão II. Fenocristais de olivina com bordas corroídas. Polarizadores descruzados. Amostra 28A.
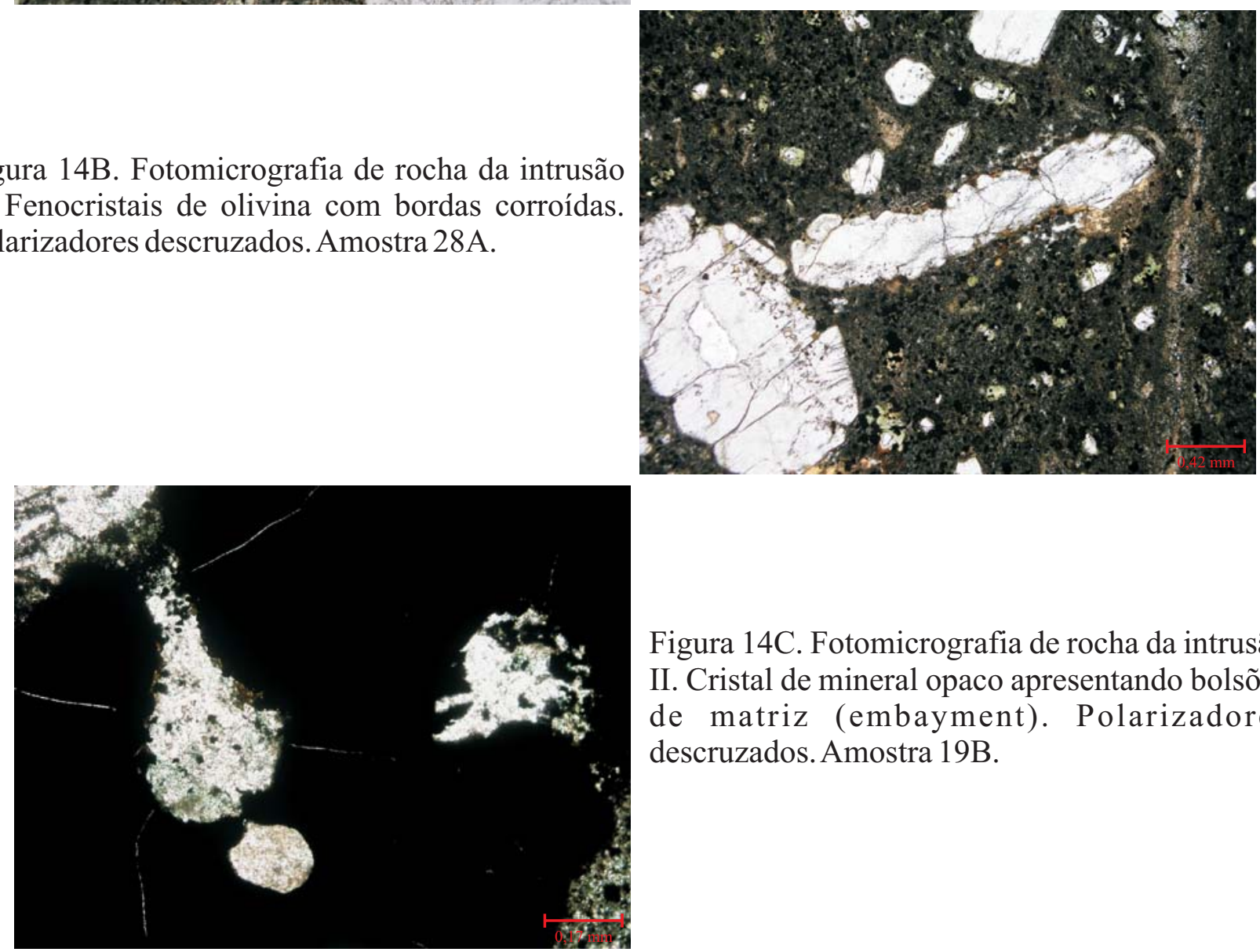

Figura 14C. Fotomicrografia de rocha da intrusão II. Cristal de mineral opaco apresentando bolsões de matriz (embayment). Polarizadores descruzados. Amostra 19B.

Figura 14D. Fotomicrografia de rocha da intrusão II. Mineral opaco (OP) apresentando inclusão de matriz. Polarizadores descruzados. Amostra 19A.

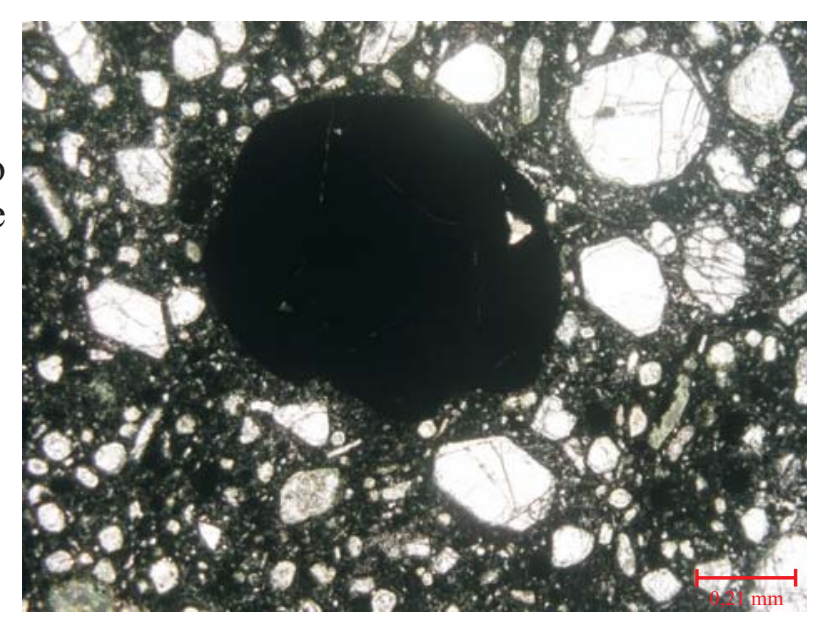




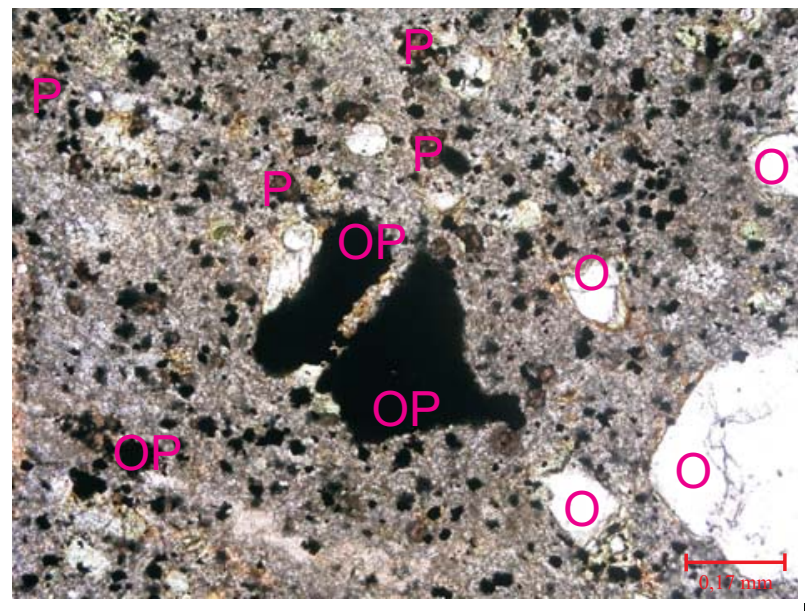

Figura 15B. Fotomicrografia de rocha da intrusão II. Micro venulação com bordas de richterita alaranjada $(\mathrm{R})$ e opacos, preenchida por agregado de minerais incolores. Polarizadores descruzados. Amostra 16A1.
Figura 15D. Fotomicrografia de rocha da intrusão II. Microvenulação com bordas de diopsídio preenchida por vidro (VV) e scherbakivita (S). Polarizadores descruzados. Amostra 02A.
Figura 15A. Fotomicrografia de rocha da intrusão II. Cristais de mineral opaco (OP), olivina $(\mathrm{O})$ e perovskita $(\mathrm{P})$. Polarizadores descruzados. Amostra 28A.
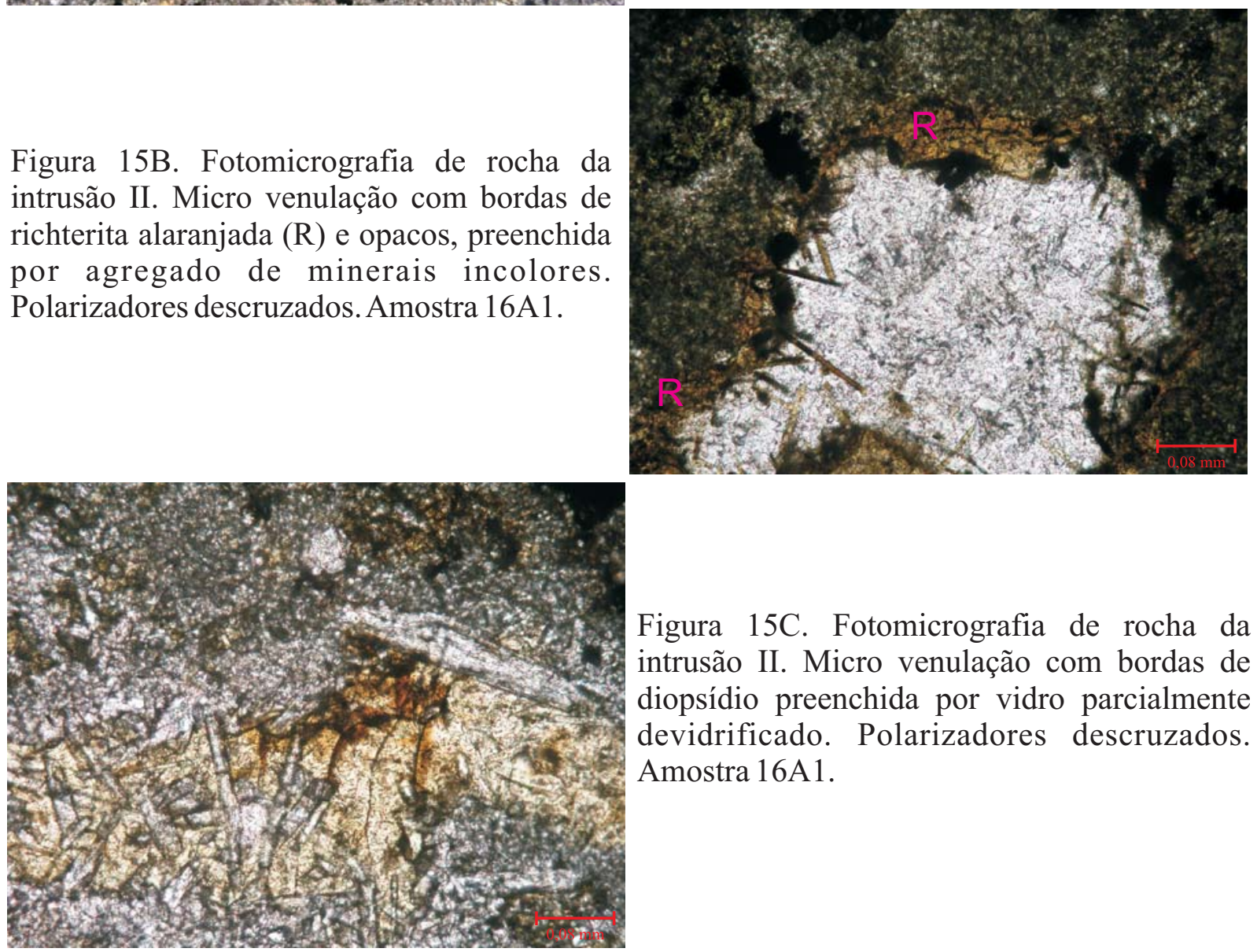

Figura 15C. Fotomicrografia de rocha da intrusão II. Micro venulação com bordas de diopsídio preenchida por vidro parcialmente devidrificado. Polarizadores descruzados. Amostra 16A1.

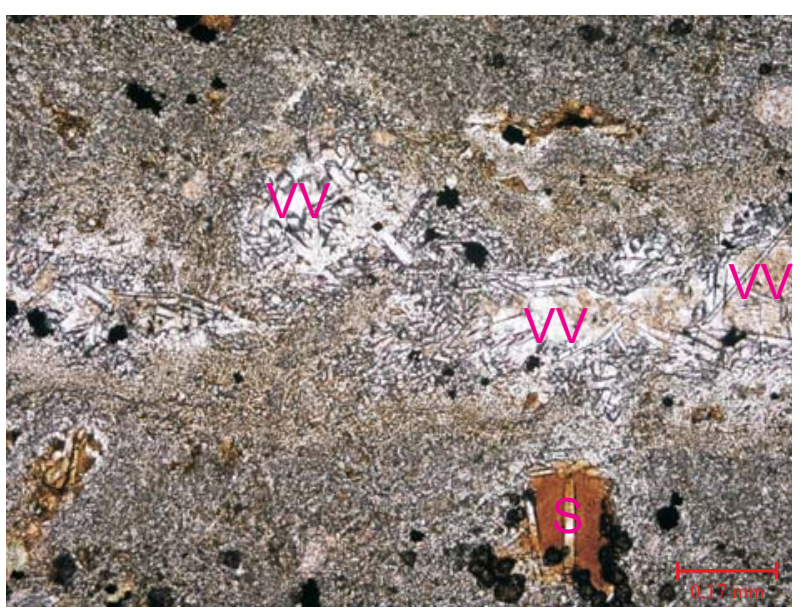


- “Lapilli" (4\%) - nódulos frequentemente arredondados, apresentando mineralogia bastante similar à da rocha da intrusão. Destacam-se na rocha hospedeira devido às diferenças texturais entre os dois litotipos, tais como: cor esverdeada (cloritizada), maior enriquecimento relativo em perovskita $(\sim 0,1 \mathrm{~mm})$, cristais de olivina bastante alterados (serpentinizados) e sinais de reabsorção em cristais de minerais opacos (Figuras 16B, 16C e 16D);

- Carbonatítico (2\%) - compõe-se de cristais subédricos de carbonatos bastante alterados, com minerais opacos dispersos e uma complexa mistura de minerais branco-amarelados de preenchimento intersticial (Figuras 17 A e 17B);

- Duníticos (7\%) - nódulos comumente arredondados, constituído essencialmente de uma intricada trama de cristais anédricos a subédricos de olivina (Figuras 17C, 17D e 18A);

- Piroxeníticos (02\%): compostos de cristais anédricos de clinopiroxênio (dipsídico), flogopita e de minerais opacos (Figuras 18B, 18C, 18D e 19A).

\subsubsection{Intrusão Indaiá II}

Os xenólitos observados nesta intrusão representam cerca de $24 \%$ do volume da rocha, sendo descritas as seguintes variedades petrográficas:

- Duníticos (5\%) - nódulos angulosos e levemente estirados (Figuras 19B e 19C), apresentando intricada trama de olivina anédrica a subédrica com cristais anédricos de minerais opacos e mineral alaranjado (scherbakovita?) ocupando os interstícios;

- Microcristalinos (5\%) - xenólitos bastante angulosos e estirados (Figuras 19D, 20A e 20B), apresentando diopsídio levemente esverdeado ripiforme entre cristais anédricos de nefelina kalsulita e agregados de minerais opacos, intersticialmente ocorre mineral alaranjado (scherbakovita?);

- "Lapilli" (2\%) - nódulos apresentando mineralogia bastante similar a rocha da intrusão, destacando-se pela sua cor esverdeada (cloritizada) e forma arredondada (Figuras 20C e 20D).

- Carbonatitíco (4\%) - nódulo com formas sinuosas e muito alterado, apresentando pseudomorfos de carbonatos enegrecidos fixados em matriz afanítica de coloração amarronzada a esbranquiçada (Figuras 21A e 21B).

- Nefelinitíco (4\%) - compõe-se de cristais euédricos a subédricos de nefelina acastanhada e cristais anédricos de kalsilita e de minerais opacos, às vezes formando agregados, com interstícios, também, preenchidos pr mineral alaranjado (scherbakovita), vide Figuras 21C e $21 \mathrm{D}$. 


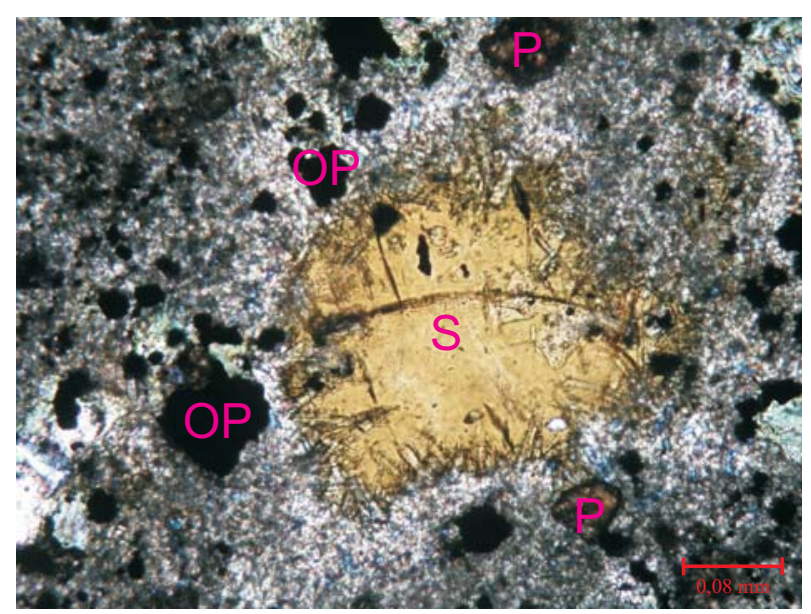

Figura 16A. Fotomicrografia de rocha da intrusão II. Microvenulação com bordas de diopsídio preenchida por scherbakivita (S). opaco (OP); perovskita (P). Polarizadores cruzados. Amostra 11E (A).

Figura 16B. Fotomicrografia de rocha da intrusão I. Xenólito carbonatítico (destacado em vermelho) incluso em xenólito "lapilli" (destacado em amarelo); olivina (O). Polarizadores descruzados. Amostra 11B2.
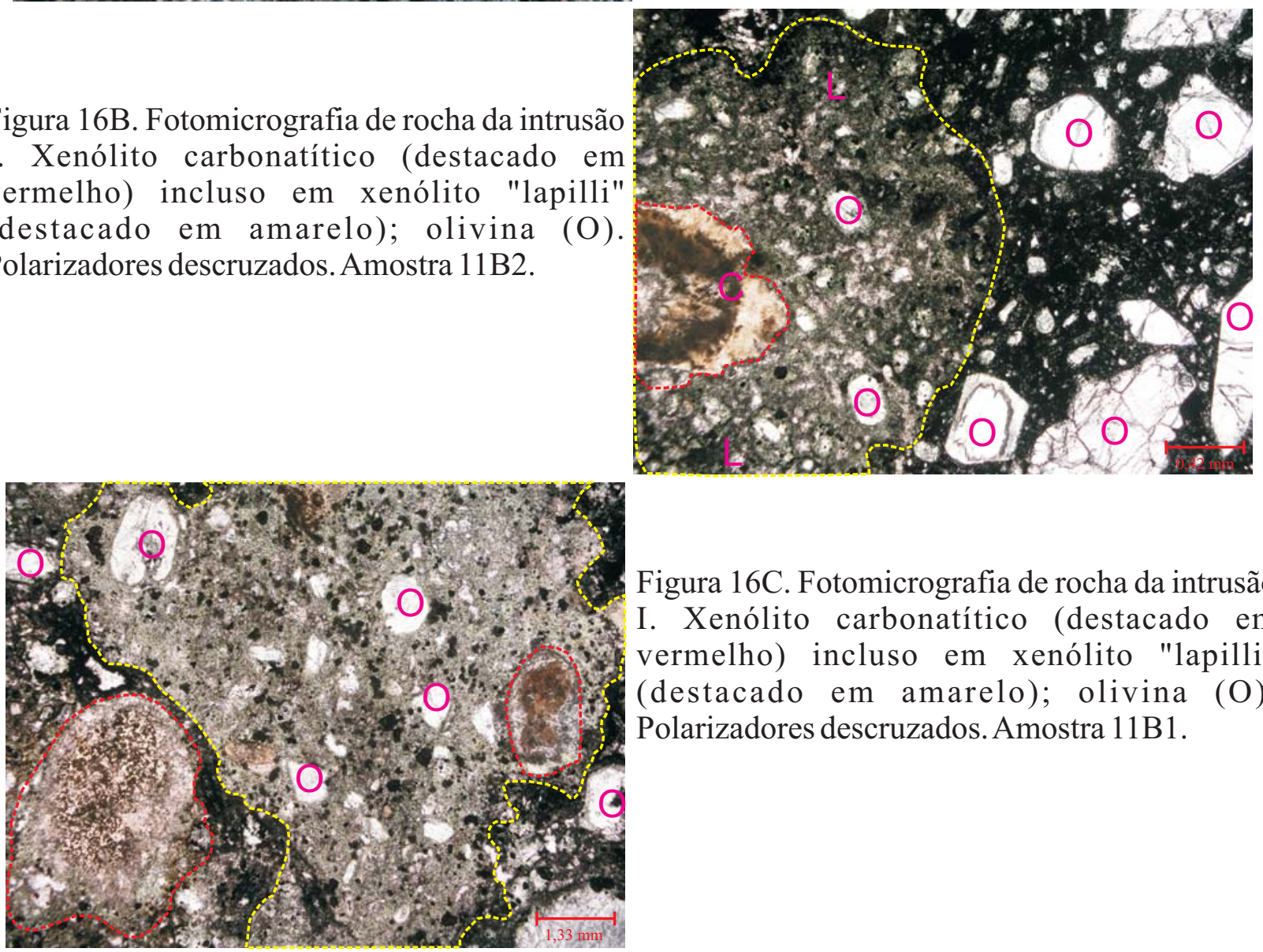

Figura 16C. Fotomicrografia de rocha da intrusão I. Xenólito carbonatítico (destacado em vermelho) incluso em xenólito "lapilli" (destacado em amarelo); olivina (O). Polarizadores descruzados. Amostra 11B1.

Figura 16D. Fotomicrografia de rocha da intrusão I. Matriz de xenólito "lapilli". Olivina (O); perovskita (P); diopsídio (D). Polarizadores descruzados. Amostra 02A.

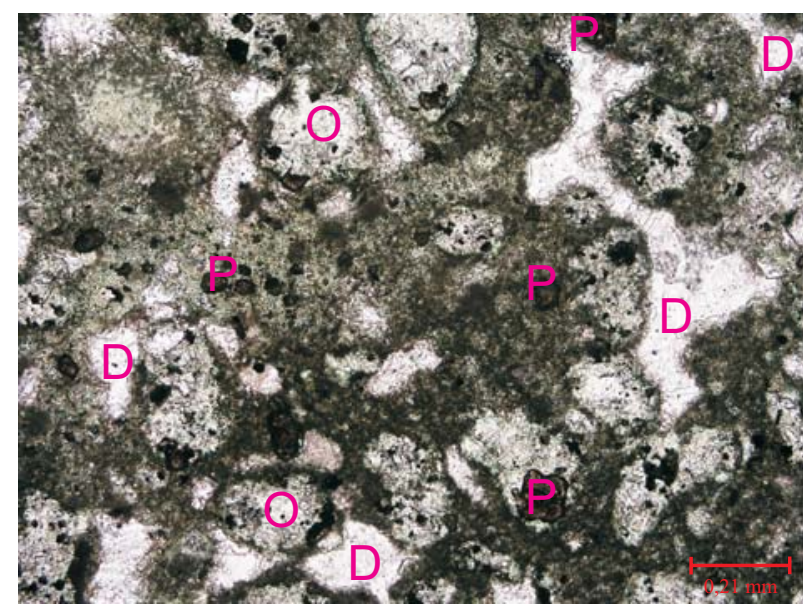




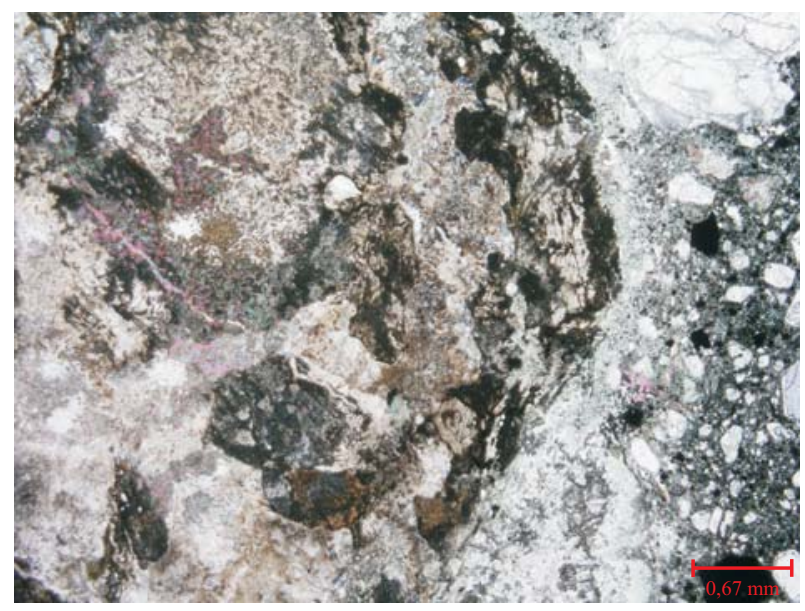

Figura 17A. Fotomicrografia de rocha da intrusão I. Xenólito carbonatítico. Polarizadores descruzados. Amostra 11E (A).

Figura 17B. Fotomicrografia de rocha da intrusão I. Matriz de xenólito carbonatítico. Polarizadores cruzados. Amostra 11B2.
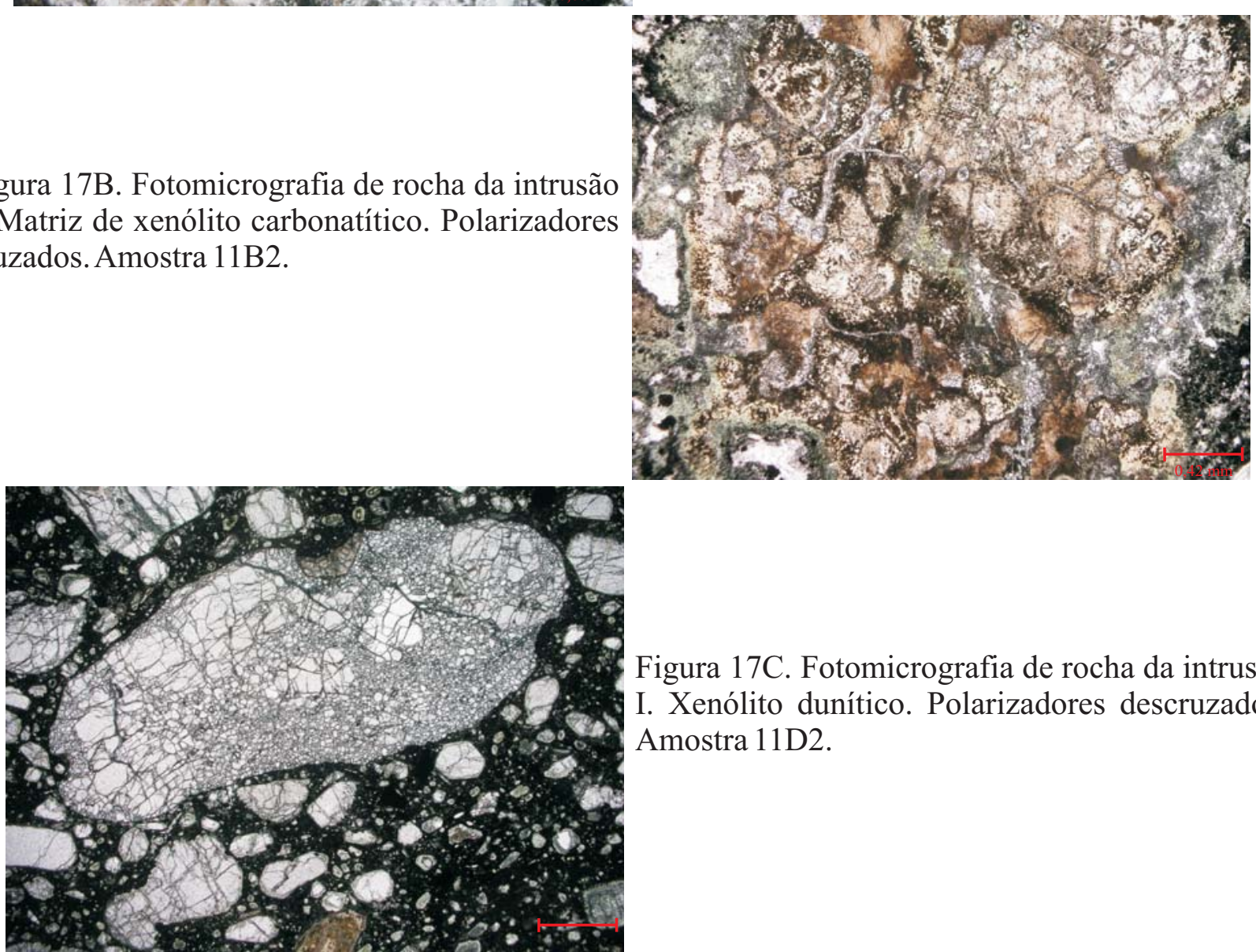

Figura 17C. Fotomicrografia de rocha da intrusão I. Xenólito dunítico. Polarizadores descruzados. Amostra 11D2.

Figura 17D. Fotomicrografia de rocha da intrusão I. Xenólito dunítico. Polarizadores cruzados. Amostra 1B(A).

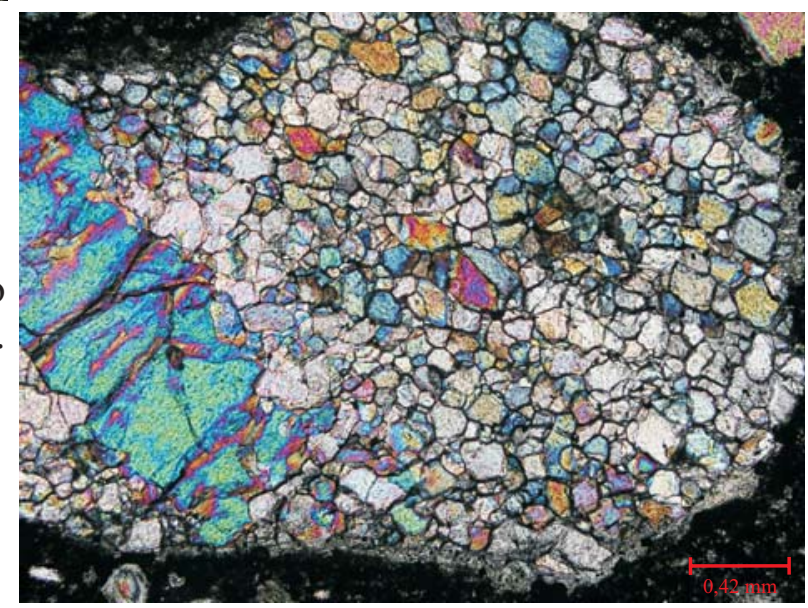




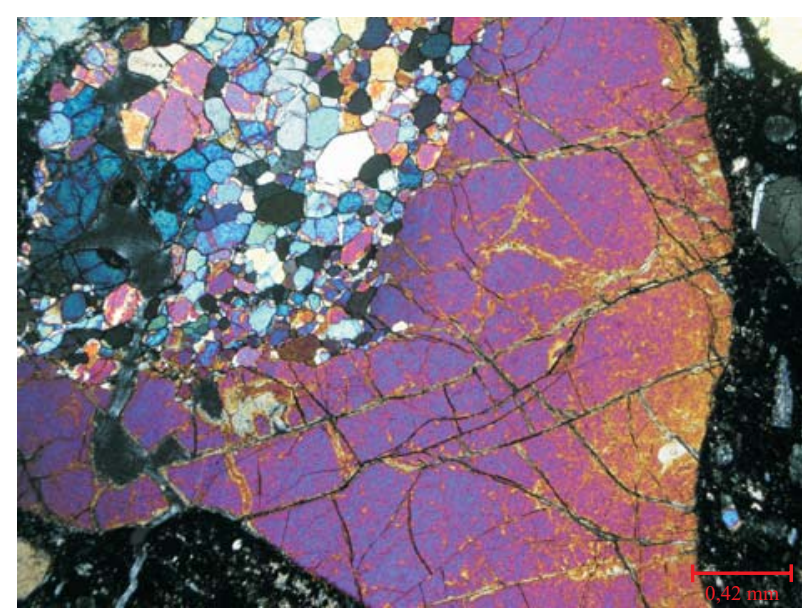

Figura 18A. Fotomicrografia de rocha da intrusão I. Xenólito dunítico. Polarizadores cruzados. Amostra 11E (A).

Figura 18B. Fotomicrografia de rocha da intrusão I. Xenólito piroxenítico. Opacos (OP); diopsídio (D); flogopita (F). Polarizadores cruzados. Amostra 04B1.
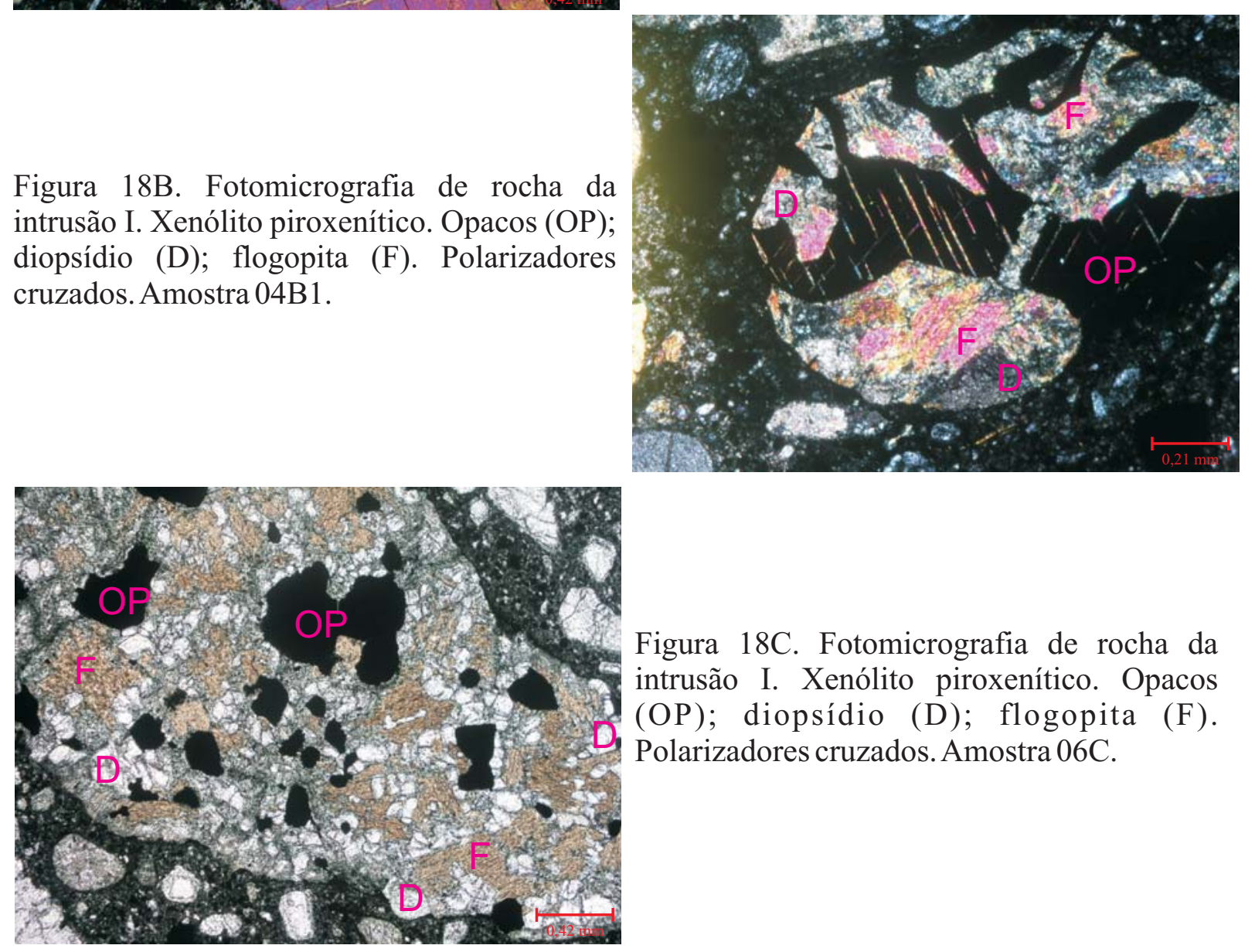

Figura 18C. Fotomicrografia de rocha da intrusão I. Xenólito piroxenítico. Opacos (OP); diopsídio (D); flogopita (F). Polarizadores cruzados. Amostra 06C.

Figura 18D. Fotomicrografia de rocha da intrusão I. Fragmento de xenólito piroxenítico. Polarizadores descruzados. Amostra 06B(B).

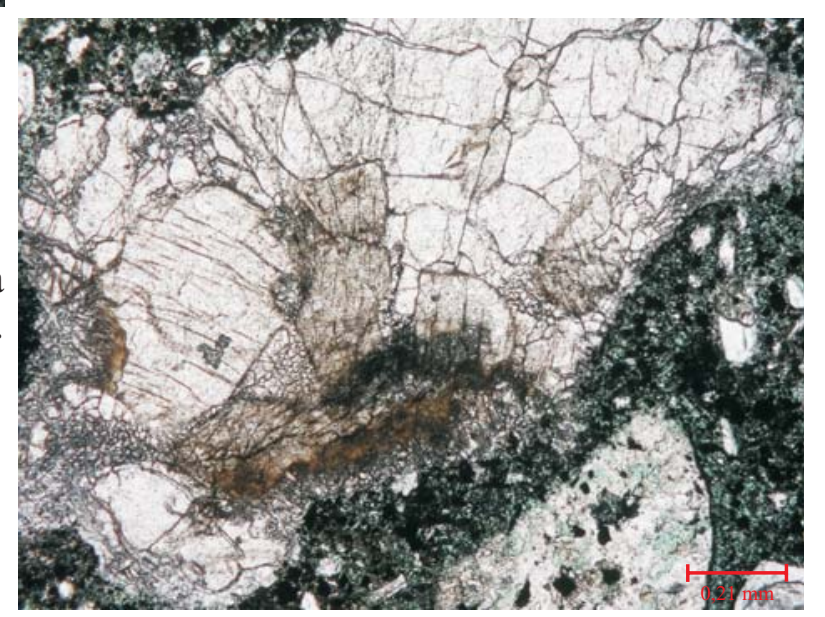




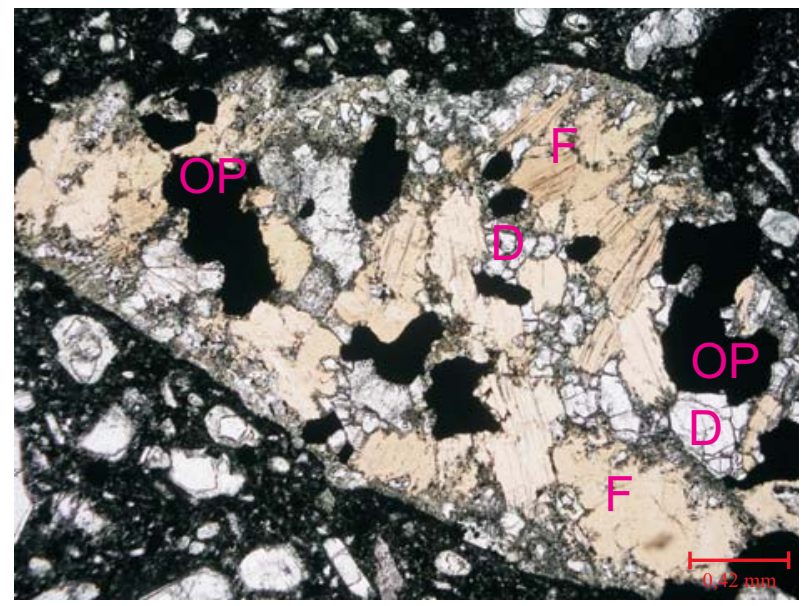

Figura 19A. Fotomicrografia de rocha da intrusão I. Xenólito piroxenítico. Opacos (OP); diopsídio (D); flogopita (F). Polarizadores descruzados. Mostra 01B(B).

Figura 19B. Fotomicrografia de rocha da intrusão II. Xenólito dunítico. Olivina $(\mathrm{O})$; scherbakovita (S). Polarizadores descruzados. Amostra 28B.
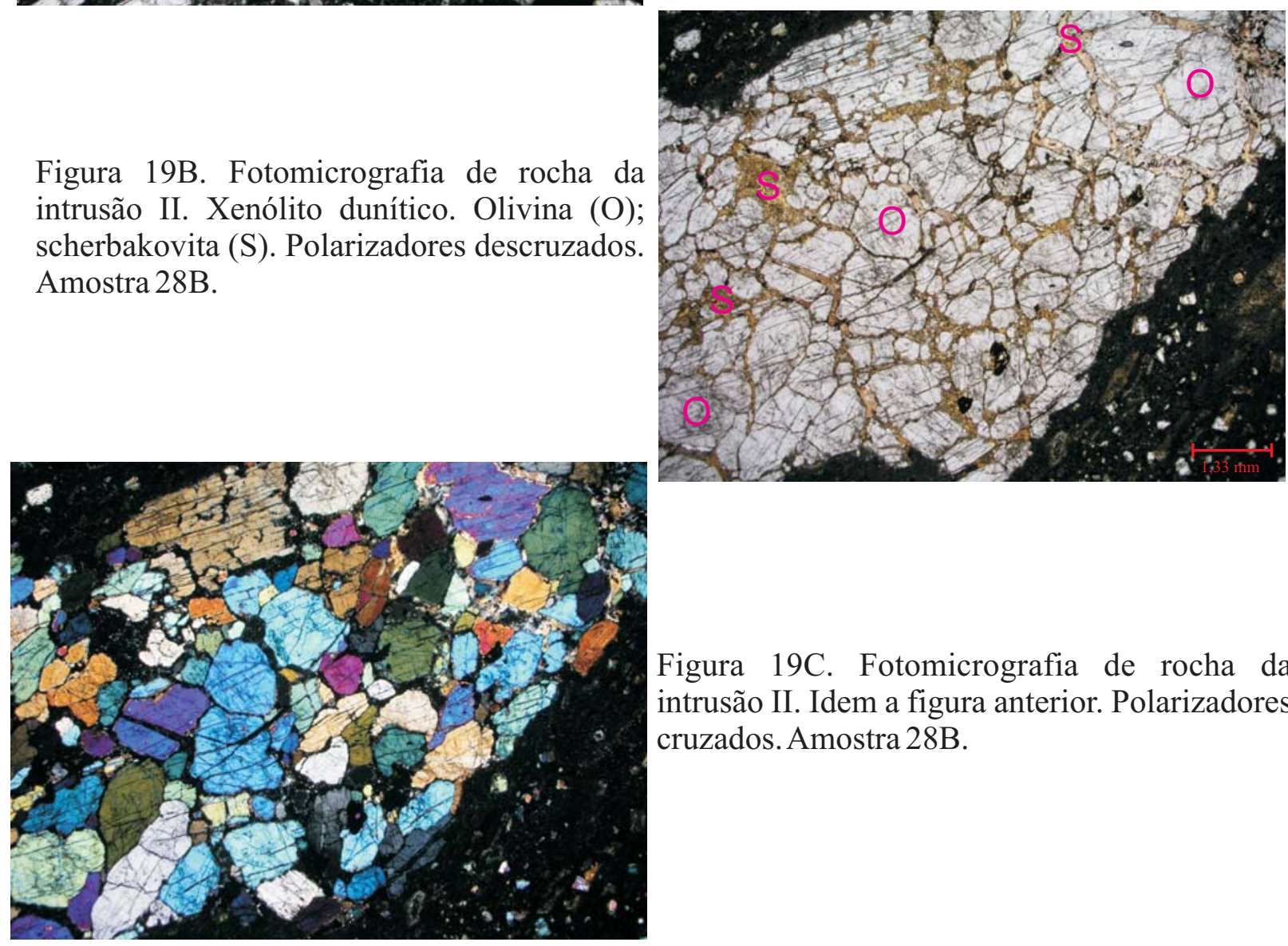

Figura 19C. Fotomicrografia de rocha da intrusão II. Idem a figura anterior. Polarizadores cruzados. Amostra 28B.

Figura 19D. Fotomicrografia de rocha da intrusão II. Xenólito microcristalino. Polarizadores descruzados. Amostra 28B.

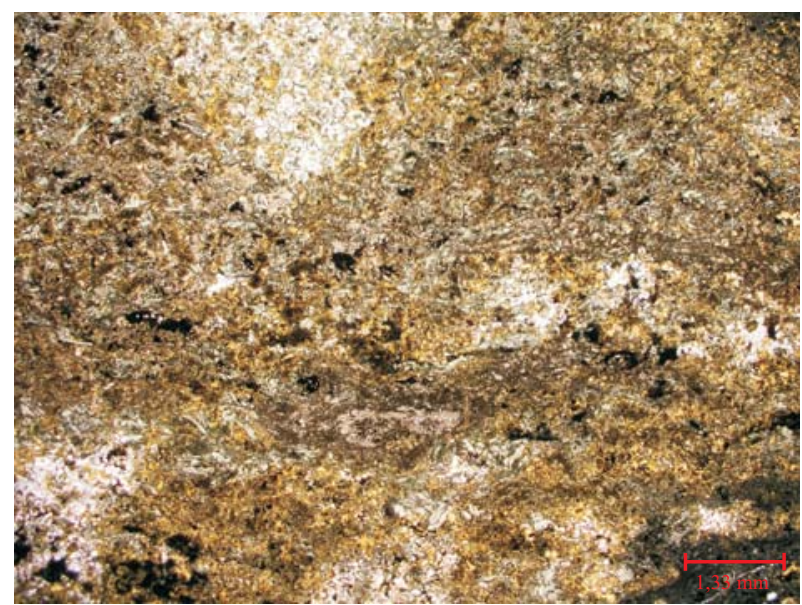




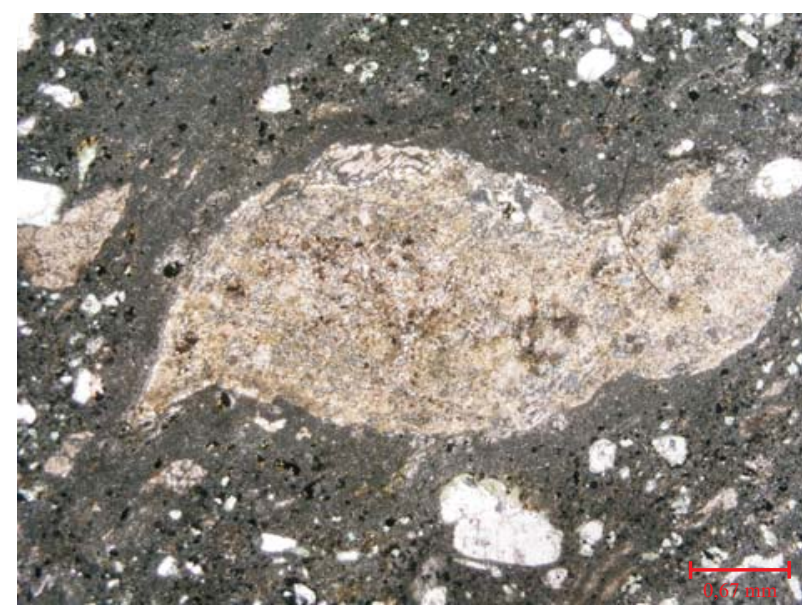

Figura 20A. Fotomicrografia de rocha da intrusão II. Xenólito microcristalino. Polarizadores descruzados. Amostra 25B.

Figura 20B. Fotomicrografia de rocha da intrusão II. Minerais inclusos no xenólito microcristalino. Nefelina (N); diopsídio (D); scherbakovita (S); opacos (OP). Polarizadores cruzados. Amostra 28B.
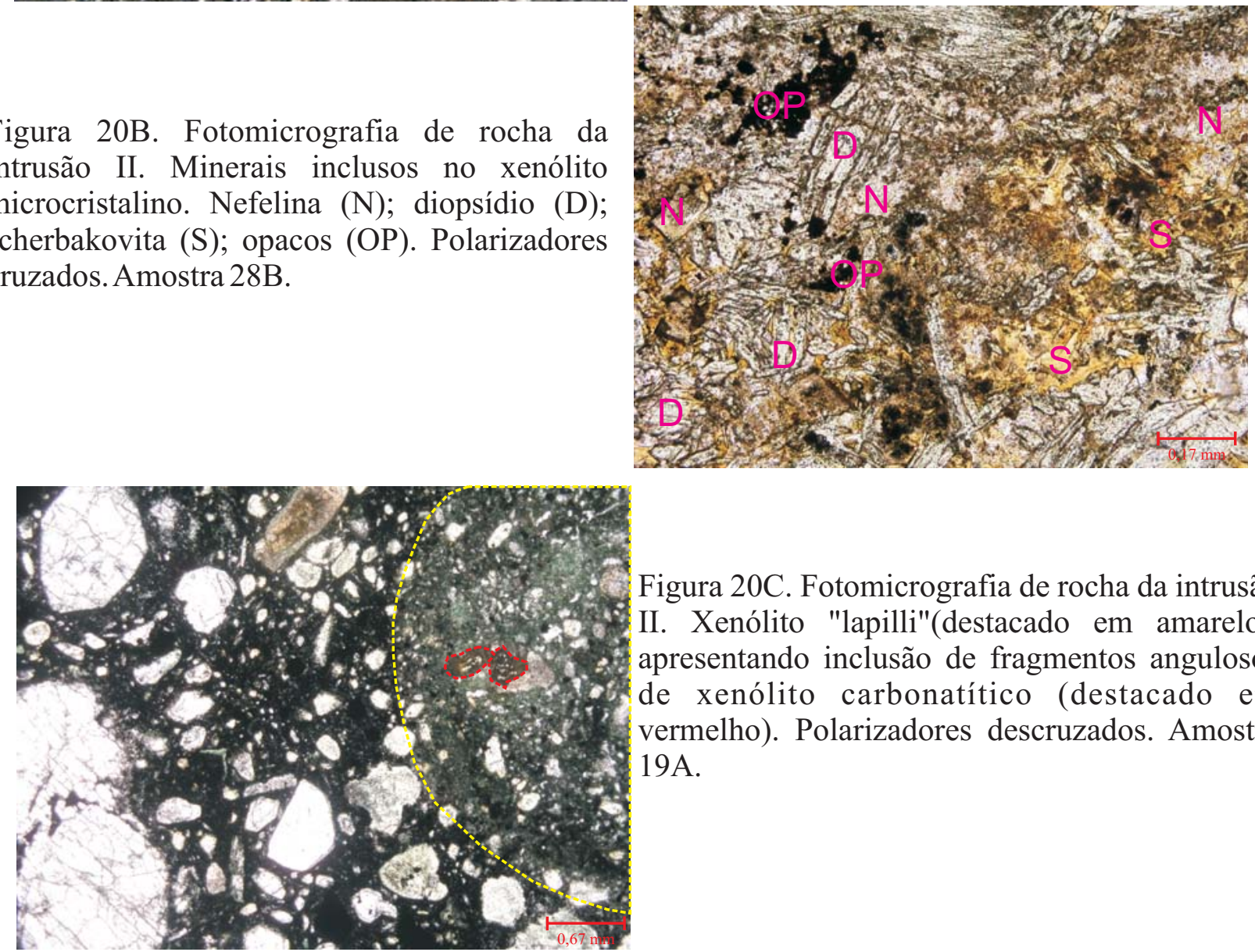

Figura 20C. Fotomicrografia de rocha da intrusão II. Xenólito "lapilli"(destacado em amarelo), apresentando inclusão de fragmentos angulosos de xenólito carbonatítico (destacado em vermelho). Polarizadores descruzados. Amostra $19 \mathrm{~A}$.

Figura 20D. Fotomicrografia de rocha da intrusão II. Detalhe do xenólito "lapilli"(destacado em amarelo), apresentando inclusão de fragmentos angulosos de xenólito carbonatítico (destacado em vermelho). Polarizadores descruzados. Amostra 19A.

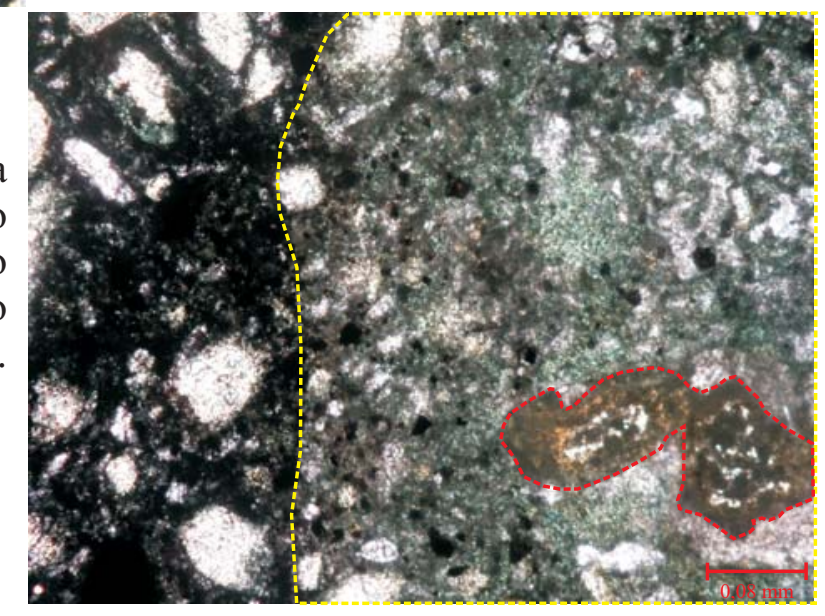




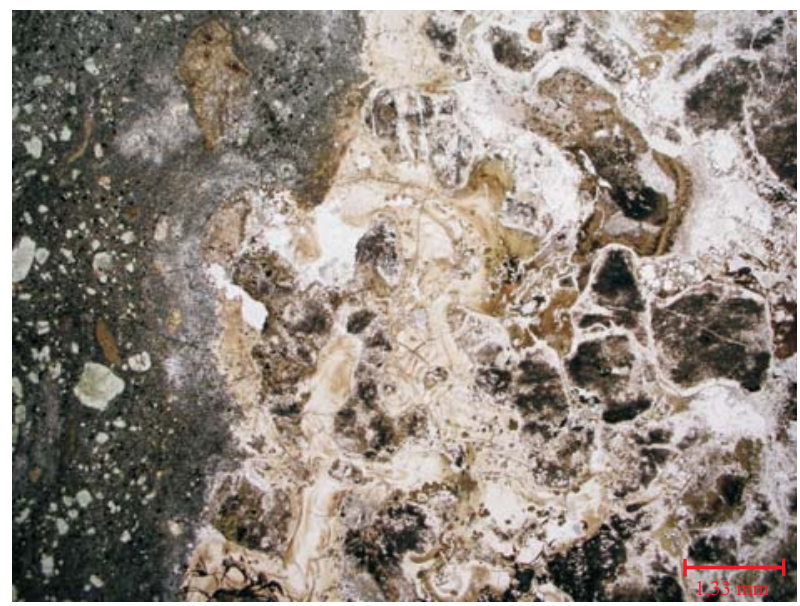

Figura 21A. Fotomicrografia de rocha da intrusão II. Xenólito carbonatitíco. Polarizadores descruzados. Amostra 19A.

Figura 21B. Fotomicrografia de rocha da intrusão II. Vista geral de xenólito carbonatitíco. Polarizadores descruzados. Amostra 19BA.
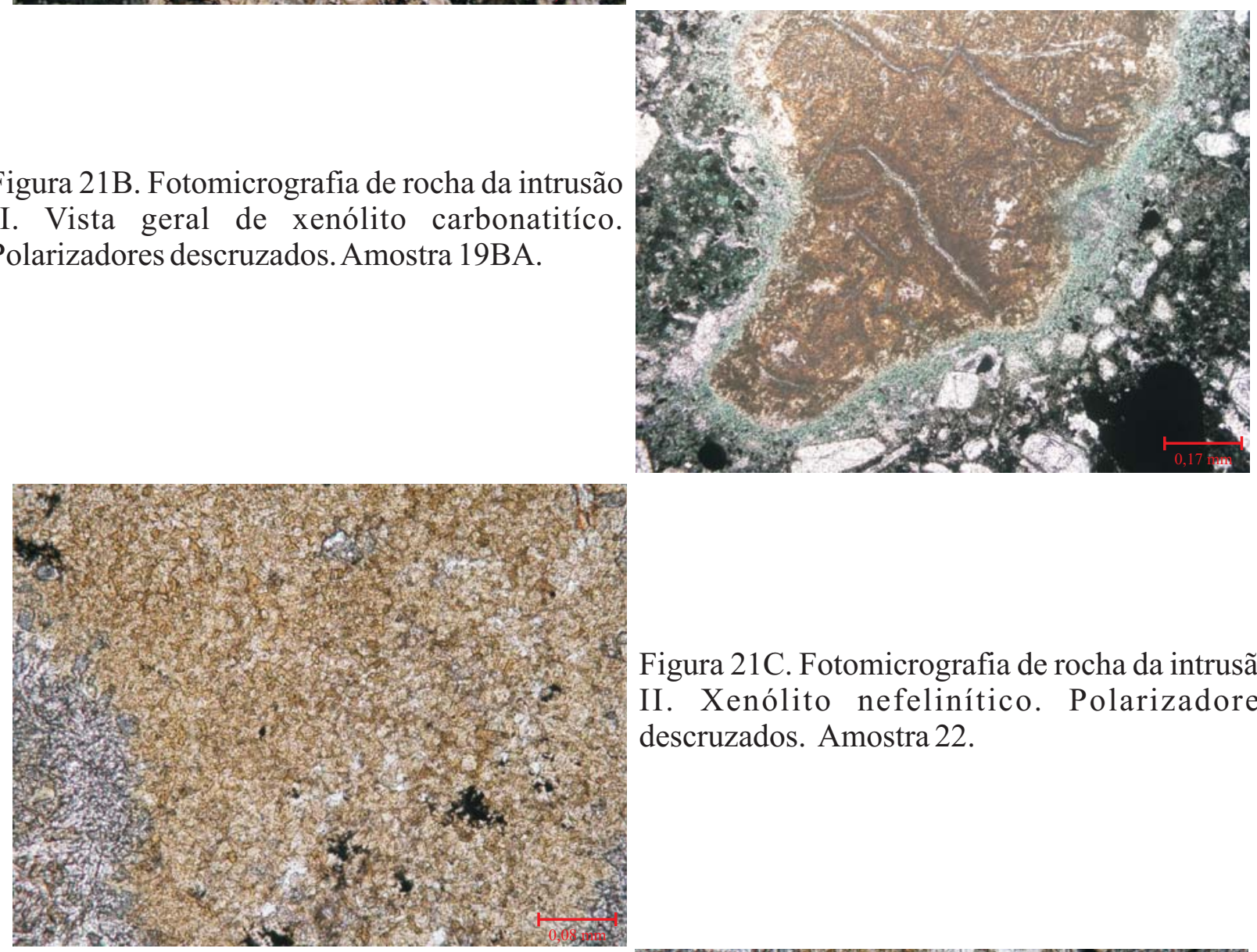

Figura 21C. Fotomicrografia de rocha da intrusão II. Xenólito nefelinítico. Polarizadores descruzados. Amostra 22.

Figura 21D. Fotomicrografia de rocha da intrusão II. Xenólito nefelinítico. Nefelina (N); kalsilita (K); opacos (OP); scherbakovita (S). Polarizadores descruzados. Amostra 22.

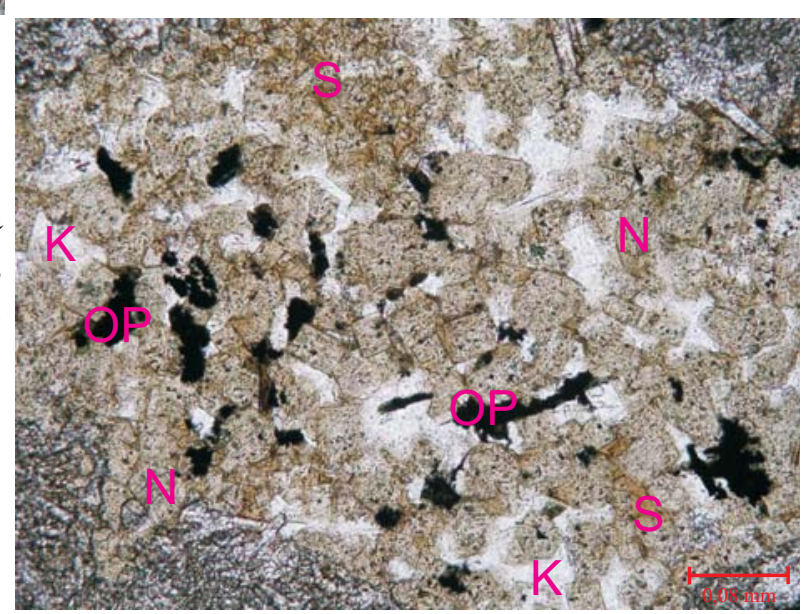




\section{Química Mineral}

\subsection{Intrusão Indaiá I}

\subsubsection{Olivina}

A composição química de olivina, determinada em macrocristais (grãos entre 0,5 e $10 \mathrm{~mm}$ ) e fenocristais $(<0,5 \mathrm{~mm})$, está representada nas tabelas 3 a 5 .

Foram realizadas 55 análises pontuais (28 em macrocristais e 16 em fenocristais) nos grãos da assembléia da rocha e 11 nos grãos de xenólitos (2 em lapilli e 9 em nódulos duníticos).

As análises realizadas nos macrocristais de olivina mostram uma composição bastante uniforme e sem estrutura zonada evidente. São três os constituintes principais destes cristais: $\mathrm{Mg}, \mathrm{Si}$

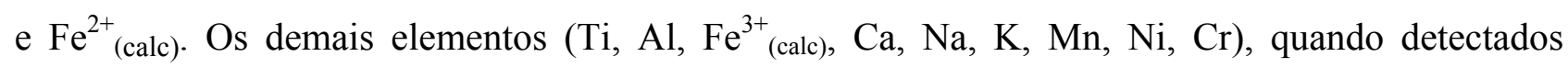
apresentam no máximo totais de 0,048 a.f.u. (átomos por fórmula unitária). Os intervalos composicionais variam de 1,662 a 1,859 a.f.u. para o $\mathrm{Mg}$, de 0,971 a 1,002 a.f.u. para o Si e de 0,120 a 0,306 a.f.u. para o $\mathrm{Fe}^{2+}$, este calculado segundo Droop (1987). Dessa forma, levando-se em consideração o histograma indicativo do intervalo composicional do componente molecular Fo, apresentado na Figura 22, os macrocristais de olivina correspondem a duas variedades de crisólita (Fo84-86 e Fo ${ }_{89-90}, 29 \%$ e 25\% das análises, respectivamente) e uma variedade de forsterita (Fo93-95 $46 \%$ das análises).

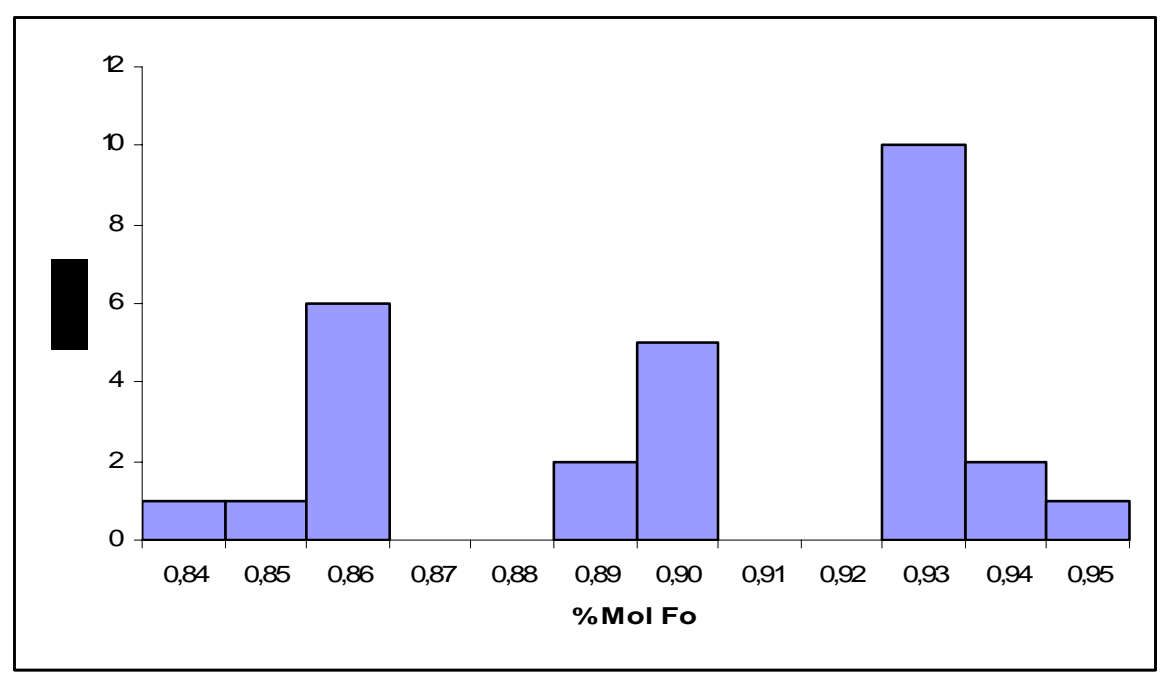

Figura 22. Histograma de composição química para macrocristais de olivina de Indaiá I. 
Tabela 3 - Composição química de macrocristais de olivina de Indaiá I. Abreviações: B, borda do grão; N, núcleo; Cr, crisolita; Fo, forsterita - abaixo do limite detecção.

$$
\begin{array}{llllllll}
\text { Grão } & 01 & 02 & 03 & 04 & 05 & 06
\end{array}
$$

\begin{tabular}{|c|c|c|c|c|c|c|c|c|c|c|c|c|c|c|}
\hline Localização & $\mathrm{B}$ & $\mathrm{N}$ & B & $\mathrm{N}$ & B & $\mathrm{N}$ & B & $\mathrm{N}$ & B & $\mathrm{N}$ & $\mathrm{B}$ & $\mathrm{N}$ & $\mathrm{B}$ & $\mathrm{N}$ \\
\hline $\mathrm{SiO}_{2}$ & 39,46 & 40,69 & 39,99 & 40,63 & 40,31 & 40,23 & 40,76 & 40,88 & 39,11 & 39,56 & 39,68 & 41,19 & 40,60 & 41,17 \\
\hline $\mathrm{TiO}_{2}$ & 0,11 & 0,06 & 0,01 & 0,07 & - & - & 0,02 & - & - & 0,06 & - & 0,01 & - & - \\
\hline $\mathrm{Al}_{2} \mathrm{O}_{3}$ & 0,05 & 0,06 & - & - & 0,01 & 0,01 & 0,03 & - & 0,01 & 0,02 & - & - & - & 0,01 \\
\hline $\mathrm{FeO}$ & 8,88 & 8,27 & 10,25 & 10,64 & 7,03 & 6,91 & 7,72 & 7,36 & 15,30 & 15,59 & 14,31 & 7,38 & 7,50 & 7,63 \\
\hline $\mathrm{MnO}$ & 0,12 & 0,91 & 0,15 & 0,15 & 0,08 & 0,11 & 0,09 & 0,13 & 0,19 & 0,13 & 0,30 & 0,08 & 0,08 & 0,09 \\
\hline $\mathrm{MgO}$ & 50,59 & 50,91 & 48,55 & 48,87 & 51,30 & 51,33 & 51,09 & 51,34 & 44,57 & 44,47 & 45,61 & 51,07 & 51,06 & 51,19 \\
\hline $\mathrm{CaO}$ & 0,11 & 0,10 & 0,02 & - & 0,03 & - & 0,03 & 0,04 & 0,08 & 0,04 & 0,14 & 0,02 & - & 0,01 \\
\hline $\mathrm{Na}_{2} \mathrm{O}$ & 0,01 & 0,02 & - & 0,01 & - & - & - & - & 0,01 & - & 0,01 & - & - & 0,02 \\
\hline $\mathrm{K}_{2} \mathrm{O}$ & 0,01 & 0,01 & 0,02 & - & - & 0,01 & 0,01 & - & - & - & - & 0,01 & - & - \\
\hline $\mathrm{Cr}_{2} \mathrm{O}_{3}$ & 0,15 & 0,12 & - & - & - & - & - & 0,01 & 0,04 & 0,02 & 0,03 & 0,01 & - & - \\
\hline $\mathrm{NiO}$ & 0,23 & 0,22 & 0,24 & 0,22 & 0,24 & 0,28 & 0,27 & 0,22 & 0,12 & 0,16 & 0,10 & 0,22 & 0,22 & 0,21 \\
\hline Total & 99,72 & 101,36 & 99,22 & 100,58 & 98,99 & 98,88 & $10-$ & 99,99 & 99,44 & 100,04 & 100,18 & 99,99 & 99,46 & 100,33 \\
\hline $\mathrm{FeO}$ & 5,95 & 6,68 & 9,23 & 10,12 & 5,46 & 5,24 & 6,69 & 6,39 & 14,31 & 15,37 & 13,50 & 7,27 & 6,37 & 7,18 \\
\hline $\mathrm{Fe}_{2} \mathrm{O}_{3}$ & 3,26 & 1,76 & 1,13 & 0,58 & 1,75 & 1,85 & 1,15 & 1,08 & 1,10 & 0,24 & 0,90 & 0,13 & 1,25 & 0,50 \\
\hline Total & 100,05 & 101,54 & 99,34 & 100,64 & 99,16 & 99,07 & 100,12 & 100,09 & 99,55 & 100,07 & 100,26 & 100,00 & 99,59 & 100,38 \\
\hline
\end{tabular}

Fórmula Estrutural calculada na base de 4 oxigênios

\begin{tabular}{|c|c|c|c|c|c|c|c|c|c|c|c|c|c|c|}
\hline \multirow[b]{2}{*}{$\mathrm{Si}$} & \multicolumn{14}{|c|}{ Fórmula Estrutural calculada na base de 4 oxigênios } \\
\hline & 0,963 & 0,979 & 0,989 & 0,993 & 0,984 & 0,983 & 0,988 & 0,990 & 0,988 & 0,996 & 0,991 & 0,999 & 0,988 & 0,995 \\
\hline $\mathrm{Ti}$ & 0,002 & 0,001 & - & 0,001 & - & - & - & - & - & 0,001 & - & - & - & - \\
\hline $\mathrm{Al}$ & 0,001 & 0,001 & - & - & - & - & - & - & - & - & - & - & - & - \\
\hline $\mathrm{Fe}^{3+}$ & 0,060 & 0,032 & 0,021 & 0,011 & 0,032 & 0,034 & 0,021 & 0,020 & 0,021 & 0,005 & 0,017 & 0,002 & 0,023 & 0,009 \\
\hline $\mathrm{Fe}^{2+}$ & 0,122 & 0,135 & 0,191 & 0,207 & 0,112 & 0,108 & 0,136 & 0,130 & 0,303 & 0,324 & 0,283 & 0,147 & 0,130 & 0,145 \\
\hline $\mathrm{Mn}$ & 0,002 & 0,013 & 0,002 & 0,002 & 0,001 & 0,001 & 0,001 & 0,002 & 0,003 & 0,002 & 0,004 & 0,001 & 0,001 & 0,001 \\
\hline $\mathrm{Mg}$ & 1,841 & 1,826 & 1,790 & 1,780 & 1,866 & 1,868 & 1,846 & 1,853 & 1,679 & 1,668 & 1,698 & 1,845 & 1,853 & 1,844 \\
\hline $\mathrm{Ca}$ & 0,002 & 0,002 & - & - & 0,001 & - & 0,001 & 0,001 & 0,001 & 0,001 & 0,002 & - & - & - \\
\hline $\mathrm{Na}$ & - & - & - & - & - & - & - & - & - & - & - & - & - & - \\
\hline $\mathrm{K}$ & - & - & - & - & - & - & - & - & - & - & - & - & - & - \\
\hline $\mathrm{Cr}$ & 0,001 & 0,001 & - & - & - & - & - & - & - & - & - & - & - & - \\
\hline $\mathrm{Ni}$ & 0,005 & 0,004 & 0,005 & 0,004 & 0,005 & 0,005 & 0,005 & 0,004 & 0,002 & 0,003 & 0,002 & 0,004 & 0,004 & 0,004 \\
\hline Cations & 2,999 & 2,994 & 2,999 & 2,999 & 3,000 & 3,000 & 2,999 & 2,999 & 2,998 & 2,999 & 2,997 & 2,999 & 3,000 & 2,999 \\
\hline \multirow[t]{3}{*}{$\mathrm{Mg} /\left(\mathrm{Mg}+\mathrm{Fe}^{2+}\right)$} & 0,94 & 0,93 & 0,90 & 0,90 & 0,94 & 0,95 & 0,93 & 0,93 & 0,85 & 0,84 & 0,86 & 0,93 & 0,93 & 0,93 \\
\hline & \multicolumn{14}{|c|}{ Nomenclatura (Deer, et al 1992) } \\
\hline & Fo & Fo & Fo & Fo & Fo & Fo & Fo & Fo & $\mathrm{Cr}$ & $\mathrm{Cr}$ & $\mathrm{Cr}$ & Fo & Fo & Fo \\
\hline
\end{tabular}


Tabela 6 - Composição química de cristais de olivina presentes em xenólitos da intrusão Indaiá I. Abreviações: B, borda do grão; N, núcleo; Cr, crisolita; Fo, forsterita; - abaixo do limite detecção.

\begin{tabular}{|c|c|c|c|c|c|c|c|c|c|c|c|}
\hline & \multicolumn{2}{|c|}{ Lapilli } & \multicolumn{9}{|c|}{ Dunítico } \\
\hline \multirow{2}{*}{$\begin{array}{c}\text { Grão } \\
\text { Localização }\end{array}$} & 01 & 02 & 01 & 02 & 03 & 04 & 05 & 06 & 07 & \multicolumn{2}{|c|}{08} \\
\hline & $\mathrm{N}$ & $\mathrm{N}$ & $\mathrm{N}$ & $\mathrm{N}$ & $\mathrm{N}$ & $\mathrm{N}$ & $\mathrm{N}$ & $\mathrm{N}$ & $\mathrm{N}$ & $\mathrm{B}$ & $\mathrm{N}$ \\
\hline $\mathrm{SiO}_{2}$ & 39,51 & 40,12 & 40,16 & 40,32 & 39,95 & 40,76 & 39,94 & 40,26 & 40,51 & 40,25 & 39,95 \\
\hline $\mathrm{TiO}_{2}$ & - & 0,10 & 0,07 & 0,06 & 0,01 & 0,02 & 0,01 & 0,06 & 0,01 & 0,02 & - \\
\hline $\mathrm{Al}_{2} \mathrm{O}_{3}$ & 0,02 & 0,01 & 0,03 & - & 0,04 & 0,02 & 0,02 & 0,01 & - & 0,02 & 0,03 \\
\hline $\mathrm{FeO}$ & 15,71 & 10,87 & 10,38 & 10,41 & 10,92 & 8,98 & 11,22 & 11,40 & 9,49 & 10,84 & 11,59 \\
\hline $\mathrm{MnO}$ & 0,14 & 0,17 & 0,15 & 0,09 & 0,12 & 0,16 & 0,15 & 0,13 & 0,08 & 0,12 & 0,13 \\
\hline $\mathrm{MgO}$ & 44,94 & 47,79 & 48,32 & 48,31 & 47,24 & 50,33 & 48,09 & 48,11 & 49,98 & 48,03 & 47,76 \\
\hline $\mathrm{CaO}$ & 0,03 & 0,14 & 0,12 & 0,15 & 0,16 & 0,02 & 0,02 & 0,05 & 0,05 & 0,14 & 0,13 \\
\hline $\mathrm{Na}_{2} \mathrm{O}$ & - & 0,01 & 0,01 & - & 0,01 & - & - & 0,01 & - & 0,02 & 0,01 \\
\hline $\mathrm{K}_{2} \mathrm{O}$ & - & - & - & - & - & - & - & - & 0,01 & 0,01 & - \\
\hline $\mathrm{Cr}_{2} \mathrm{O}_{3}$ & - & 0,07 & 0,09 & 0,13 & 0,09 & 0,03 & - & 0,07 & 0,01 & 0,02 & 0,07 \\
\hline $\mathrm{NiO}$ & 0,15 & 0,28 & 0,26 & 0,29 & 0,26 & 0,24 & 0,20 & 0,19 & 0,21 & 0,23 & 0,26 \\
\hline Total & 100,50 & 99,55 & 99,58 & 99,75 & 98,79 & 100,56 & 99,64 & 100,28 & 100,33 & 99,68 & 99,95 \\
\hline $\mathrm{FeO}$ & 14,66 & 10,61 & 10,01 & 10,26 & 10,79 & 8,01 & 10,10 & 10,77 & 8,16 & 10,45 & 10,63 \\
\hline $\mathrm{Fe}_{2} \mathrm{O}_{3}$ & 1,17 & 0,29 & 0,42 & 0,16 & 0,15 & 1,08 & 1,25 & 0,70 & 1,47 & 0,43 & 1,07 \\
\hline \multirow[t]{2}{*}{ Total } & 100,62 & 99,58 & 99,62 & 99,77 & 98,80 & 100,67 & 99,77 & 100,35 & 100,48 & 99,73 & 100,06 \\
\hline & \multicolumn{11}{|c|}{ Fórmula Estrutural calculada na base de 04 oxigênios } \\
\hline $\mathrm{Si}$ & 0,989 & 0,994 & 0,992 & 0,995 & 0,998 & 0,989 & 0,988 & 0,991 & 0,986 & 0,995 & 0,988 \\
\hline $\mathrm{Ti}$ & - & 0,002 & 0,001 & 0,001 & - & - & - & 0,001 & - & - & - \\
\hline $\mathrm{Al}$ & - & - & - & - & 0,001 & - & - & - & - & - & - \\
\hline $\mathrm{Fe}^{3+}$ & 0,022 & 0,005 & 0,008 & 0,003 & 0,003 & 0,020 & 0,023 & 0,013 & 0,027 & 0,008 & 0,020 \\
\hline $\mathrm{Fe}^{2+}$ & 0,308 & 0,220 & 0,207 & 0,212 & 0,225 & 0,163 & 0,209 & 0,222 & 0,167 & 0,216 & 0,220 \\
\hline $\mathrm{Mn}$ & 0,003 & 0,004 & 0,003 & 0,002 & 0,003 & 0,003 & 0,003 & 0,003 & 0,002 & 0,002 & 0,003 \\
\hline $\mathrm{Mg}$ & 1,676 & 1,765 & 1,779 & 1,777 & 1,759 & 1,820 & 1,772 & 1,765 & 1,813 & 1,769 & 1,760 \\
\hline $\mathrm{Ca}$ & 0,001 & 0,004 & 0,003 & 0,004 & 0,004 & 0,001 & - & 0,001 & 0,001 & 0,004 & 0,003 \\
\hline $\mathrm{Na}$ & - & - & - & - & - & - & - & - & - & - & - \\
\hline $\mathrm{K}$ & - & - & - & - & - & - & - & - & - & - & - \\
\hline $\mathrm{Cr}$ & - & 0,001 & 0,001 & 0,001 & 0,001 & - & - & 0,001 & - & - & 0,001 \\
\hline $\mathrm{Ni}$ & 0,003 & 0,006 & 0,005 & 0,006 & 0,005 & 0,005 & 0,004 & 0,004 & 0,004 & 0,005 & 0,005 \\
\hline Cátions & 3,001 & 3,000 & 3,000 & 3,000 & 3,000 & 3,000 & 3,001 & 3,000 & 3,001 & 3,000 & 3,001 \\
\hline \multirow[t]{3}{*}{$\mathrm{Mg} /(\mathrm{Mg}+\mathrm{Fe})$} & 0,84 & 0,89 & 0,90 & 0,89 & 0,89 & 0,92 & 0,89 & 0,89 & 0,92 & 0,89 & 0,89 \\
\hline & \multicolumn{11}{|c|}{ Nomenclatura (Deer, et al 1992) } \\
\hline & $\mathrm{Cr}$ & $\mathrm{Cr}$ & Fo & $\mathrm{Cr}$ & $\mathrm{Cr}$ & Fo & $\mathrm{Cr}$ & $\mathrm{Cr}$ & Fo & $\mathrm{Cr}$ & $\mathrm{Cr}$ \\
\hline
\end{tabular}


Tabela 4 - Composição química de macrocristais de olivina de Indaiá I. Abreviações: B, borda do grão; N, núcleo; Cr, crisolita; Fo, forsterita; - abaixo do limite detecção.

\begin{tabular}{|c|c|c|c|c|c|c|c|c|c|c|c|c|c|c|}
\hline \multirow{2}{*}{$\begin{array}{c}\text { Grão } \\
\text { Localização }\end{array}$} & \multicolumn{2}{|c|}{08} & \multicolumn{2}{|c|}{09} & \multicolumn{2}{|c|}{10} & \multicolumn{2}{|c|}{11} & \multicolumn{2}{|c|}{12} & \multicolumn{2}{|c|}{13} & \multicolumn{2}{|c|}{14} \\
\hline & B & $\mathrm{N}$ & $\mathrm{B}$ & $\mathrm{N}$ & $\mathrm{B}$ & $\mathrm{N}$ & B & $\mathrm{N}$ & B & $\mathrm{N}$ & B & $\mathrm{N}$ & $\mathrm{B}$ & $\mathrm{N}$ \\
\hline $\mathrm{SiO}_{2}$ & 39,88 & 39,95 & 40,67 & 41,08 & 39,54 & 39,96 & 39,93 & 39,34 & 40,32 & 40,12 & 39,88 & 40,75 & 40,60 & 39,72 \\
\hline $\mathrm{A} 2 \mathrm{O}_{3}$ & - & 0,04 & - & 0,01 & 0,01 & - & 0,03 & 0,02 & - & 0,01 & 0,03 & 0,01 & - & - \\
\hline $\mathrm{FeO}$ & 13,07 & 11,03 & 7,30 & 7,31 & 13,69 & 13,57 & 11,33 & 11,59 & 10,81 & 11,23 & 13,95 & 7,74 & 8,50 & 13,98 \\
\hline $\mathrm{MgO}$ & 45,91 & 48,00 & 50,28 & 50,11 & 45,77 & 45,77 & 47,58 & 47,61 & 48,55 & 48,60 & 45,38 & 51,26 & 51,10 & 46,24 \\
\hline $\mathrm{CaO}$ & 0,08 & 0,10 & - & 0,02 & 0,05 & 0,02 & 0,12 & 0,14 & 0,05 & 0,06 & 0,07 & 0,03 & 0,03 & 0,04 \\
\hline $\mathrm{Na}_{2} \mathrm{O}$ & - & 0,01 & - & - & 0,02 & - & 0,02 & 0,02 & 0,04 & - & - & - & - & 0,02 \\
\hline $\mathrm{K}_{2} \mathrm{O}$ & - & - & - & - & 0,01 & 0,02 & - & 0,01 & 0,01 & 0,01 & 0,01 & 0,01 & - & - \\
\hline $\mathrm{FeO}$ & 13,01 & 10,24 & 6,89 & 6,75 & 13,03 & 13,47 & 10,83 & 9,90 & 9,94 & 9,88 & 13,71 & 6,48 & 6,71 & 12,92 \\
\hline $\mathrm{Fe}_{2} \mathrm{O}_{3}$ & 0,07 & 0,87 & 0,46 & 0,62 & 0,72 & 0,10 & 0,56 & 1,87 & 0,96 & 1,51 & 0,27 & 1,40 & 1,99 & 1,19 \\
\hline \multirow[t]{2}{*}{ Total } & 99,36 & 99,59 & 99,34 & 99,51 & 99,61 & 99,75 & 99,59 & 99,46 & 100,23 & 100,63 & 99,74 & 100,21 & 100,85 & 100,46 \\
\hline & \multicolumn{14}{|c|}{ Fórmula Estrutural calculada na base de 4 oxigênios } \\
\hline $\mathrm{Si}$ & 1,000 & 0,989 & 0,996 & 1,005 & 0,992 & 1,000 & 0,991 & 0,979 & 0,991 & 0,984 & 1,000 & 0,987 & 0,980 & 0,988 \\
\hline $\mathrm{Ti}$ & - & - & - & 0,001 & 0,001 & 0,001 & 0,001 & 0,001 & - & 0,001 & 0,001 & - & 0,001 & - \\
\hline $\mathrm{Na}$ & - & - & - & - & - & - & - & - & 0,001 & - & - & - & - & - \\
\hline $\mathrm{K}$ & - & - & - & - & - & - & - & - & - & - & - & - & - & - \\
\hline $\mathrm{Cr}$ & - & - & - & - & - & - & 0,001 & 0,001 & - & - & - & - & - & - \\
\hline $\mathrm{Ni}$ & 0,004 & 0,005 & 0,018 & 0,015 & 0,003 & 0,002 & 0,006 & 0,006 & 0,004 & 0,004 & 0,002 & 0,004 & 0,005 & 0,002 \\
\hline Cations & 2,998 & 2,999 & 2,999 & 2,999 & 2,998 & 2,998 & 2,998 & 2,998 & 2,999 & 2,999 & 2,997 & 3,000 & 3,000 & 2,999 \\
\hline $\mathrm{Mg} /\left(\mathrm{Mg}+\mathrm{Fe}^{2+}\right)$ & 0,86 & 0,89 & 0,93 & 0,93 & 0,86 & 0,86 & 0,89 & 0,90 & 0,90 & 0,90 & 0,86 & 0,93 & 0,93 & 0,86 \\
\hline & \multicolumn{14}{|c|}{ Nomenclatura (Deer, et al 1992) } \\
\hline
\end{tabular}


Tabela 5 - Composição química de fenocristais de olivina de Indaiá I. Abreviações: B, borda do grão; N, núcleo; Cr, crisolita; Fo, forsterita; - abaixo do limite detecção.

\begin{tabular}{|c|c|c|c|c|c|c|c|c|c|c|c|c|c|c|c|c|}
\hline \multirow{2}{*}{$\begin{array}{l}\text { Grão } \\
\text { Local }\end{array}$} & \multicolumn{2}{|c|}{01} & \multicolumn{2}{|c|}{02} & \multicolumn{2}{|c|}{03} & \multicolumn{2}{|c|}{04} & \multicolumn{2}{|c|}{05} & \multicolumn{2}{|c|}{06} & \multicolumn{2}{|c|}{07} & \multicolumn{2}{|c|}{08} \\
\hline & $\mathrm{B}$ & $\mathrm{N}$ & $\mathrm{B}$ & $\mathrm{N}$ & $\mathrm{B}$ & $\mathrm{N}$ & $\mathrm{B}$ & $\mathrm{N}$ & $\mathrm{B}$ & $\mathrm{N}$ & $\mathrm{B}$ & $\mathrm{N}$ & $\mathrm{B}$ & $\mathrm{N}$ & $\mathrm{B}$ & $\mathrm{N}$ \\
\hline $\mathrm{SiO}_{2}$ & 40,06 & 39,61 & 40,64 & 41,25 & 39,57 & 39,17 & 39,73 & 39,40 & 40,64 & 41,25 & 40,33 & 39,83 & 41,18 & 39,60 & 41,42 & 41,04 \\
\hline $\mathrm{TiO}_{2}$ & 0,01 & 0,00 & - & - & 0,07 & - & 0,09 & 0,01 & - & - & 0,04 & 0,04 & 0,07 & 0,05 & 0,01 & 0,03 \\
\hline $\mathrm{A} 12 \mathrm{O}_{3}$ & 0,01 & 0,03 & - & - & 0,01 & - & 0,02 & 0,01 & - & - & 0,03 & 0,03 & - & - & - & - \\
\hline $\mathrm{FeO}$ & 14,11 & 13,55 & 9,15 & 7,53 & 13,99 & 15,24 & 14,14 & 16,43 & 9,15 & 7,53 & 11,06 & 11,79 & 7,62 & 14,87 & 7,32 & 7,68 \\
\hline $\mathrm{MnO}$ & 0,24 & 0,18 & 0,09 & 0,08 & 0,26 & 0,14 & 0,22 & 0,22 & 0,09 & 0,08 & 0,11 & 0,13 & 0,10 & 0,37 & 0,12 & 0,09 \\
\hline $\mathrm{MgO}$ & 45,61 & 45,70 & 50,25 & 51,44 & 45,79 & 44,58 & 46,06 & 43,68 & 50,25 & 51,44 & 47,83 & 47,29 & 50,88 & 45,69 & 51,21 & 51,04 \\
\hline $\mathrm{CaO}$ & 0,12 & 0,08 & 0,05 & 0,02 & 0,07 & 0,04 & 0,09 & 0,05 & 0,05 & 0,02 & 0,16 & 0,14 & 0,02 & 0,28 & 0,01 & 0,04 \\
\hline $\mathrm{Na}_{2} \mathrm{O}$ & - & 0,03 & 0,02 & - & - & - & - & 0,01 & 0,02 & - & 0,02 & 0,02 & 0,01 & - & 0,01 & 0,01 \\
\hline $\mathrm{K}_{2} \mathrm{O}$ & 0,01 & - & - & - & 0,01 & - & 0,03 & 0,01 & - & - & 0,01 & 0,01 & - & 0,01 & 0,02 & - \\
\hline $\mathrm{Cr}_{2} \mathrm{O}_{3}$ & 0,06 & 0,10 & - & 0,02 & 0,07 & 0,03 & 0,03 & - & - & 0,02 & 0,13 & 0,15 & 0,02 & - & - & - \\
\hline $\mathrm{NiO}$ & 0,09 & 0,17 & 0,21 & 0,26 & 0,10 & 0,14 & 0,11 & 0,12 & 0,21 & 0,26 & 0,23 & 0,22 & 0,26 & 0,07 & 0,21 & 0,23 \\
\hline Total & 100,31 & 99,43 & 100,42 & 100,58 & 99,93 & 99,34 & 100,51 & 99,93 & 100,42 & 100,58 & 99,95 & 99,62 & 100,15 & 100,93 & 100,31 & 100,15 \\
\hline $\mathrm{FeO}$ & 14,03 & 13,27 & 7,89 & 6,95 & 13,27 & 14,42 & 13,23 & 16,14 & 7,89 & 6,95 & 11,02 & 11,23 & 7,60 & 13,33 & 7,22 & 7,14 \\
\hline $\mathrm{Fe}_{2} \mathrm{O}_{3}$ & 0,09 & 0,31 & 1,40 & 0,64 & 0,80 & 0,91 & 1,01 & 0,32 & 1,40 & 0,64 & 0,04 & 0,63 & 0,03 & 1,71 & 0,11 & 0,59 \\
\hline \multirow[t]{2}{*}{ Total } & 100,32 & 99,47 & 100,56 & 100,65 & 100,01 & 99,43 & 100,61 & 99,97 & 100,56 & 100,65 & 99,95 & 99,68 & 100,15 & 101,10 & 100,32 & 100,21 \\
\hline & \multicolumn{16}{|c|}{ Fórmula Estrutural calculada na base de 4 oxigênios } \\
\hline $\mathrm{Si}$ & 0,999 & 0,994 & 0,987 & 0,994 & 0,990 & 0,991 & 0,988 & 0,997 & 0,987 & 0,994 & 0,996 & 0,990 & 0,998 & 0,983 & 1,001 & 0,994 \\
\hline $\mathrm{Ti}$ & - & - & - & - & 0,001 & - & 0,002 & - & - & - & 0,001 & 0,001 & 0,001 & 0,001 & - & 0,001 \\
\hline $\mathrm{Al}$ & - & - & - & - & - & - & - & - & - & - & - & - & - & - & - & - \\
\hline $\mathrm{Fe}^{3+}$ & 0,002 & 0,006 & 0,026 & 0,012 & 0,015 & 0,017 & 0,019 & 0,006 & 0,026 & 0,012 & 0,001 & 0,012 & 0,001 & 0,032 & 0,002 & 0,011 \\
\hline $\mathrm{Fe}^{2+}$ & 0,293 & 0,279 & 0,161 & 0,140 & 0,278 & 0,305 & 0,276 & 0,342 & 0,161 & 0,140 & 0,228 & 0,234 & 0,154 & 0,278 & 0,146 & 0,145 \\
\hline $\mathrm{Mn}$ & 0,005 & 0,004 & 0,002 & 0,002 & 0,006 & 0,003 & 0,005 & 0,005 & 0,002 & 0,002 & 0,002 & 0,003 & 0,002 & 0,008 & 0,002 & 0,002 \\
\hline $\mathrm{Mg}$ & 1,695 & 1,710 & 1,819 & 1,847 & 1,707 & 1,680 & 1,706 & 1,647 & 1,819 & 1,847 & 1,761 & 1,751 & 1,838 & 1,691 & 1,844 & 1,843 \\
\hline $\mathrm{Ca}$ & 0,003 & 0,002 & 0,001 & - & 0,002 & 0,001 & 0,002 & 0,001 & 0,001 & - & 0,004 & 0,004 & 0,001 & 0,008 & - & 0,001 \\
\hline $\mathrm{Na}$ & - & 0,001 & 0,001 & - & - & - & - & - & 0,001 & - & 0,001 & - & - & - & - & - \\
\hline $\mathrm{K}$ & - & - & - & - & - & - & - & - & - & - & - & - & - & - & - & - \\
\hline $\mathrm{Cr}$ & 0,001 & 0,001 & - & - & 0,001 & - & - & - & - & - & 0,001 & 0,001 & - & - & - & - \\
\hline $\mathrm{Ni}$ & 0,002 & 0,003 & 0,004 & 0,005 & 0,002 & 0,003 & 0,002 & 0,002 & 0,004 & 0,005 & 0,005 & 0,004 & 0,005 & 0,001 & 0,004 & 0,004 \\
\hline Cations & 3,000 & 3,000 & 3,001 & 3,000 & 3,001 & 3,001 & 3,001 & 3,000 & 3,001 & 3,000 & 3,000 & 3,000 & 3,000 & 3,001 & 3,000 & 3,000 \\
\hline \multirow[t]{3}{*}{$\mathrm{Mg} /\left(\mathrm{Mg}+\mathrm{Fe}^{2+}\right)$} & 0,85 & 0,86 & 0,92 & 0,93 & 0,86 & 0,85 & 0,86 & 0,83 & 0,92 & 0,93 & 0,89 & 0,88 & 0,92 & 0,86 & 0,93 & 0,93 \\
\hline & \multicolumn{16}{|c|}{ Nomenclatura (Deer, et al 1992) } \\
\hline & $\mathrm{Cr}$ & $\mathrm{Cr}$ & Fo & Fo & $\mathrm{Cr}$ & $\mathrm{Cr}$ & $\mathrm{Cr}$ & $\mathrm{Cr}$ & Fo & Fo & $\mathrm{Cr}$ & $\mathrm{Cr}$ & Fo & $\mathrm{Cr}$ & Fo & Fo \\
\hline
\end{tabular}

A composição dos fenocristais de olivina é também bastante uniforme e sem zoneamento químico. Os principais constituintes da estrutura mineral determinados são $\mathrm{Mg}(1,647$ a 1,847 a.f.u.), $\mathrm{Si}\left(0,983\right.$ a 1,001 a.f.u.) e $\mathrm{Fe}^{2+}$ (calc) $(0,140$ a 0,342 a.f.u.), com os demais analisados (Ti, $\mathrm{Al}$, $\mathrm{Fe}^{3+}, \mathrm{Ca}, \mathrm{Na}, \mathrm{K}, \mathrm{Mn}, \mathrm{Ni}, \mathrm{Cr}$ ) apresentando no máximo totais de 0,032 a.f.u. Dessa forma, levando em consideração o histograma indicativo de variações dos componentes moleculares, apresentado na Figura 23, os fenocristais de olivina podem ser reunidos em três variedades de crisólita $\left(\mathrm{Fo}_{83}\right.$, $\mathrm{Fo}_{85-86}$ e $\mathrm{Fo}_{88-89}, 6 \%, 38 \%$ e 13\% das análises, respectivamente) e uma variedade de forsterita (Fo F2- $_{92}$ 93 44\% das análises). 


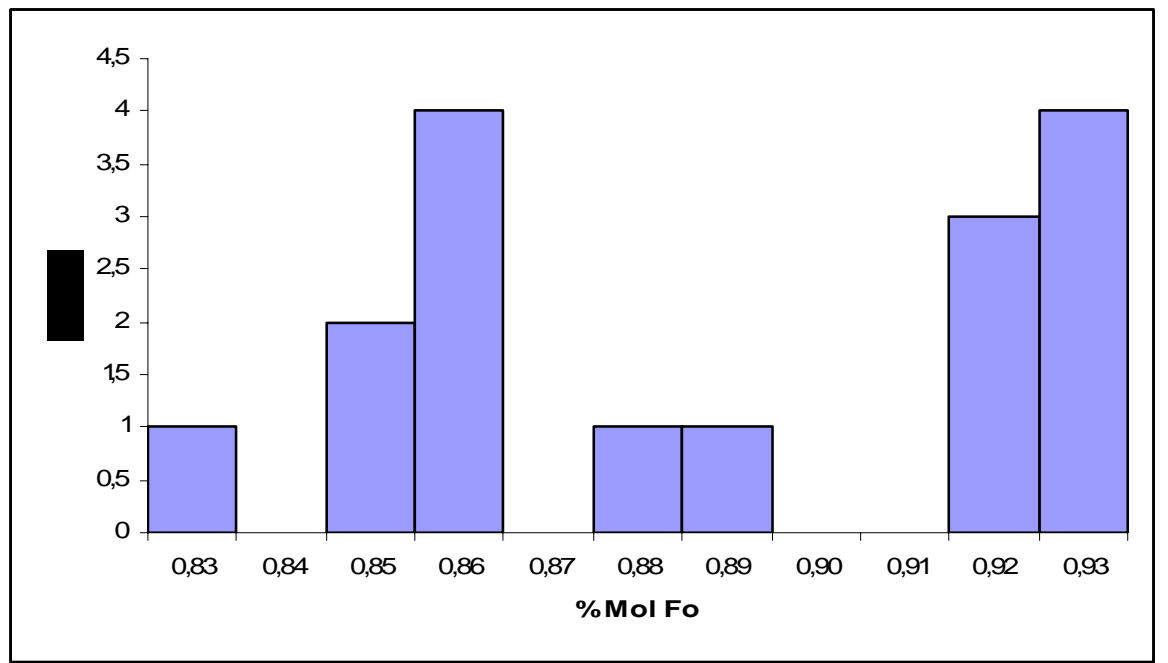

FIGURA 23. Histograma de composição química para fenocristais de olivina de Indaiá I.

As análises realizadas em olivina presente nos xenólitos estão reunidas na Tabela 6 . No xenólito dunítico, percebe-se um sutil empobrecimento de Fe do núcleo para a borda, com conseqüente enriquecimento de $\mathrm{Mg}$. Já no lapilli, o zoneamento composicional da olivina é evidente, com $\mathrm{FeO}$ variando de 15,71 a $10,87 \%$ e $\mathrm{MgO}$ de 44,94 a 47,79\%, respectivamente da borda para o núcleo. São três os principais constituintes destes cristais: $\mathrm{Mg}$ (1,676 a 1,880 a.f.u.), Si (0,986 a 0,998 a.f.u.) e $\mathrm{Fe}^{2+}$ (calc) $(0,163$ a 0,308 a.f.u.). Os demais elementos analisados, quando detectados, apresentam no máximo totais de 0,022 a.f.u. Considerando o histograma de variações moleculares (Figura 24), podem-se separar os cristais de olivina em duas variedades de crisólita (Fo F4 $_{4}$, no lapilli e Fo $89-90$, nos dois xenólitos analisados) e uma de forsterita (Fo92, 18\% das análises), esta última somente no xenólito dunítico.

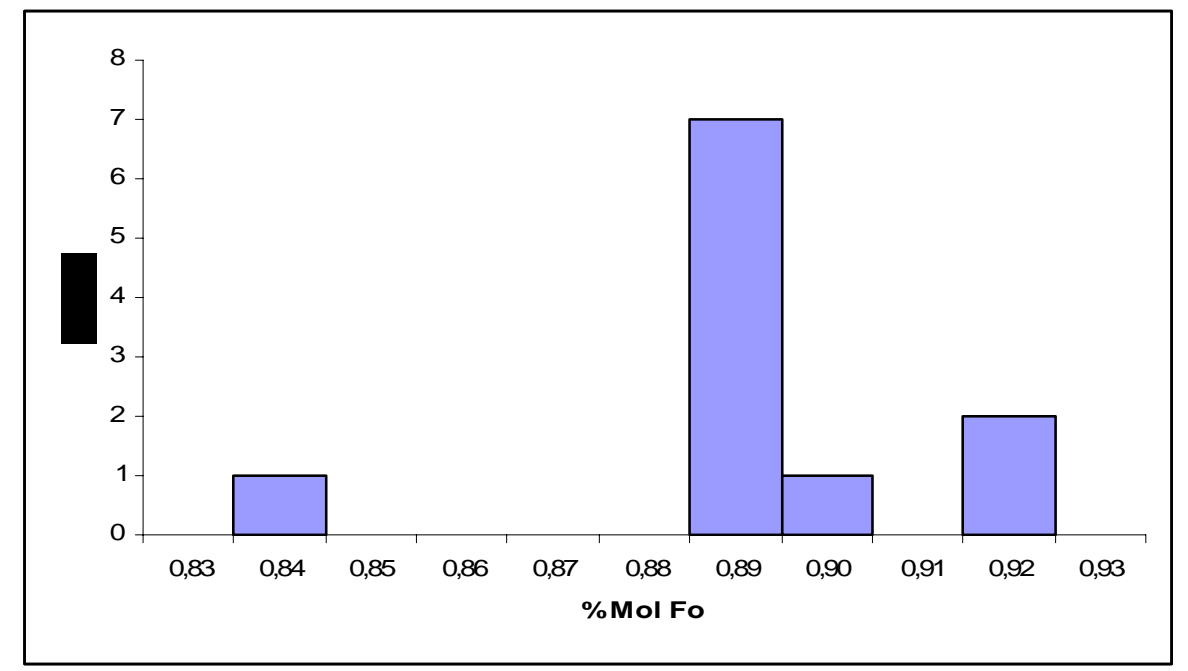

FIGURA 24. Histograma de composição química para olivinas presentes nos xenólitos de Indaiá I. 


\subsubsection{Piroxênios}

A composição química dos piroxênios que constituem os macrocristais (5 a 8,5 mm) de ortopiroxênio presentes na assembléia da rocha e dos cristais presentes em xenólitos piroxeníticos, encontra-se listada nas tabelas 7 e 8 , respectivamente.

Foram realizadas 15 análises, sendo 12 associadas aos macrocristais apresentando bordas quelifitizadas e 3 em cristais de xenólitos piroxeníticos. Nos macrocristais foram realizadas análises de borda e centro e nos demais foram efetuadas análises pontuais no centro dos cristais.

Os dados obtidos por intermédio das análises são apresentados nos diagramas para classificação de piroxênios Q-J e Ca-Mg-Fe (Figuras 25A, B e C).

Nos diagramas, os macrocristais de ortopiroxênios destacam-se pela sua variação composicional rica em $\mathrm{Mg}$ e Fe, que podem ser classificados como enstatita $\left(\mathrm{En}_{85,29} \mathrm{Fs}_{12,70} \mathrm{Wo}_{1,54}\right.$, porcentagem média dos membros finais), com fórmula média representada por $\left(\mathrm{Fe}^{3+}{ }_{0,03} \mathrm{Ti}_{0,01} \mathrm{Mg}_{1,70} \mathrm{Fe}^{2+}{ }_{0,21} \mathrm{Mn}_{0,01} \mathrm{Cr}^{3+}{ }_{0,01} \mathrm{Ca}_{0,03} \mathrm{Na}_{0,01}\right)_{2,00}\left(\mathrm{Si}_{1,97} \mathrm{Al}_{0,02} \mathrm{Fe}^{3+}{ }_{0,01}\right)_{2,00}$.

Os sítios tetraédricos dos macrocristais de enstatita são ocupados predominantemente por Si e quantidades insuficientes de Al (até 0,041 a.f.u.) para preencher o sítio. Essa deficiência é compensada com a entrada de $\mathrm{Fe}^{3+}$. O sítio M1 é ocupado preferencialmente por $\mathrm{Mg}(0,699$ a 0,786 a.f.u.) e quantidades reduzidas de $\mathrm{Ti}, \mathrm{Fe}^{2+}, \mathrm{Cr}$ e $\mathrm{Ni}$. O sítio $\mathrm{M} 2$ é ocupado quase que em sua totalidade por $\mathrm{Mg}(0,621$ a 0,98 a.f.u.), sendo desprezível a contribuição de $\mathrm{Ca}$ e $\mathrm{Na}$.

$\mathrm{Na}$ Tabela 7, não se observam variações nos cristais (e.g. FeO, $\mathrm{MgO}$ nas bordas e núcleos) sugestivas de zoneamento químico.

No xenólito piroxenítico, os cristais de piroxênio têm uma variação composicional rica em Ca e $\mathrm{Mg}$, podendo ser classificados como diopsídio $\left(\mathrm{En}_{44,33} \mathrm{Fs}_{6,93} \mathrm{Wo}_{45,85}\right.$, porcentagem média de membros finais), apresentando a fórmula média equivalente a $\left(\mathrm{Fe}^{3+}{ }_{0,12} \mathrm{Mg}_{0,89} \mathrm{Cr}^{3+}{ }_{0,01} \mathrm{Ca}_{0,92} \mathrm{Na}_{0,06}\right)_{2,00}$ $\left(\mathrm{Si}_{1,98} \mathrm{Al}_{0,01} \mathrm{Fe}^{3+}{ }_{0,01}\right)_{2,00}$.

O sítio tetraédrico destes cristais são ocupados por Si (1,99 a 1,97 a.f.u.) e pequenas quantidades de $\mathrm{Al}$ (até 0,005 .f.u.) e $\mathrm{Fe}^{3+}$ (até 0,024 a.f.u.). O sítio M1 é ocupado preferencialmente por $\mathrm{Mg}\left(0,863\right.$ a 0,871 a.f.u.) e quantidades menores de $\mathrm{Fe}^{3+}$ (máximo de 0,13 a.f.u.) e reduzidas de Ti e Cr. O sítio M2 é ocupado em quase sua totalidade por Ca (0,903 a 0,931 a.f.u.), com diminuta quantidade de $\mathrm{Mg}$ (máximo de 0,042 a.f.u.) e de $\mathrm{Mn}$ e $\mathrm{Na}$ (máximo de 0,066 a.f.u.). 
Tabela 7 - Composição química de macrocristais de ortopiroxênios da intrusão Indaiá I. Abreviações: B, borda do grão; $\mathrm{N}$, núcleo; - abaixo do limite detecção.

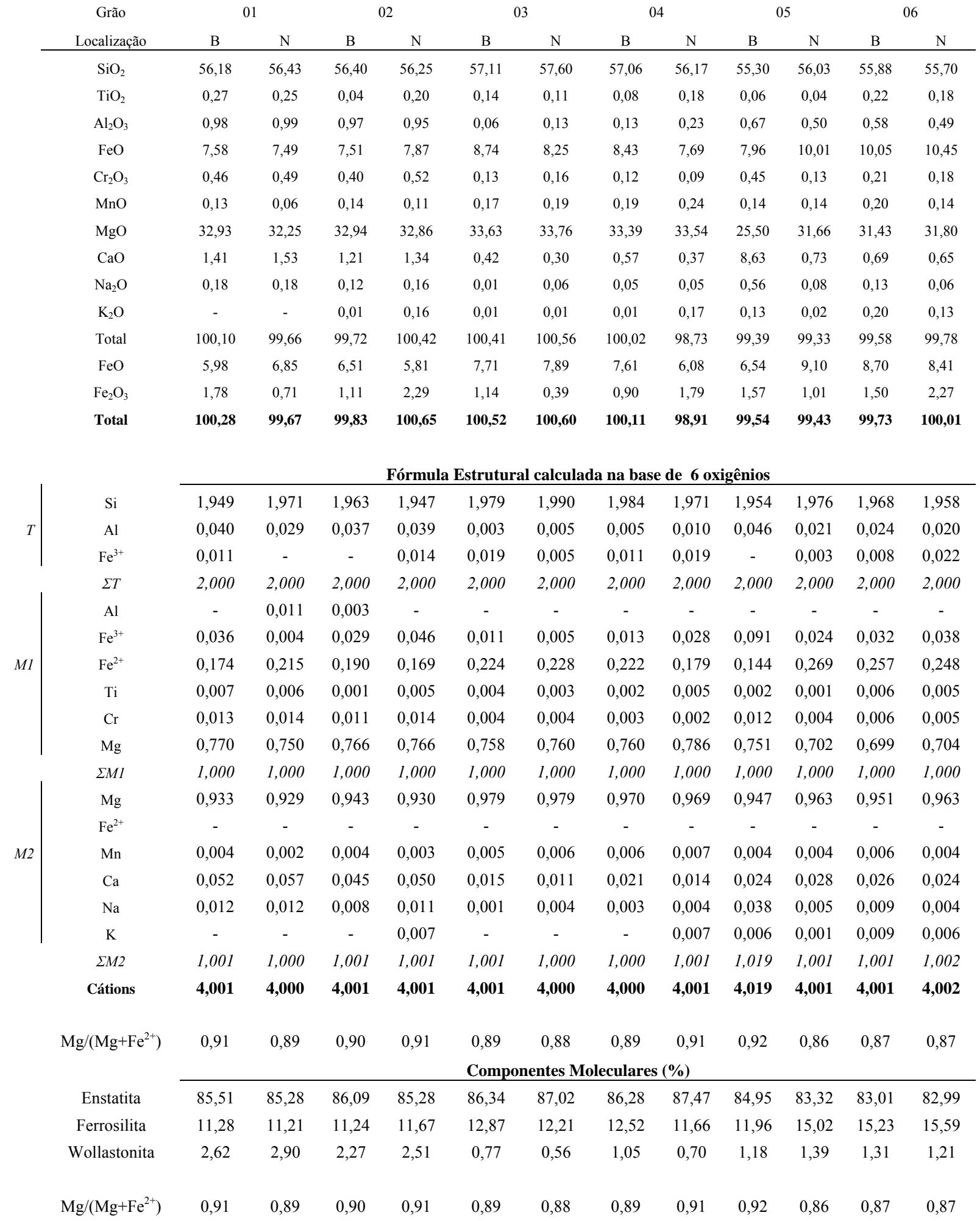


Tabela 8 - Composição química de piroxênios de xenólitos piroxeníticos da intrusão Indaiá I. Abreviações: N, núcleo; abaixo do limite detecção.

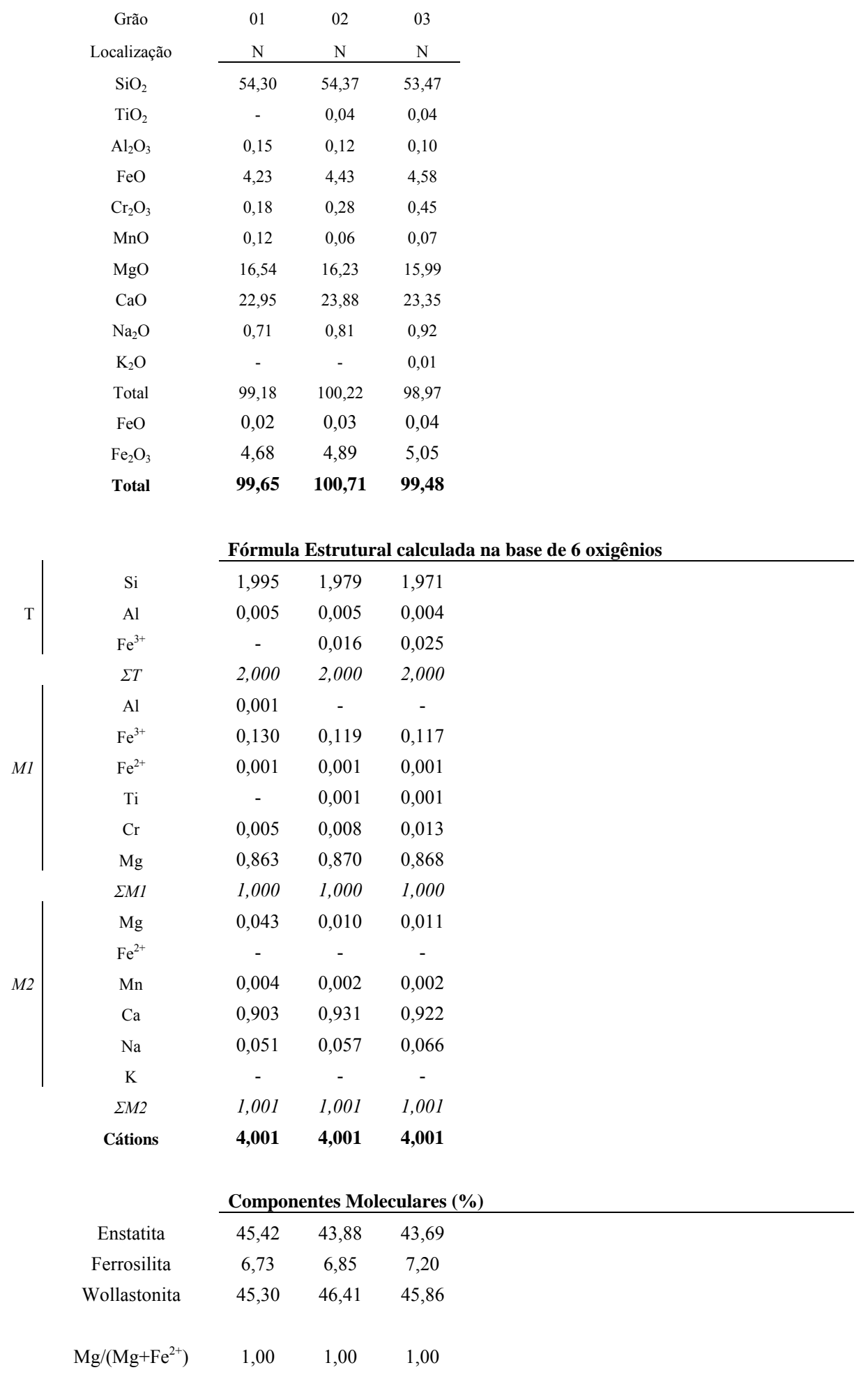



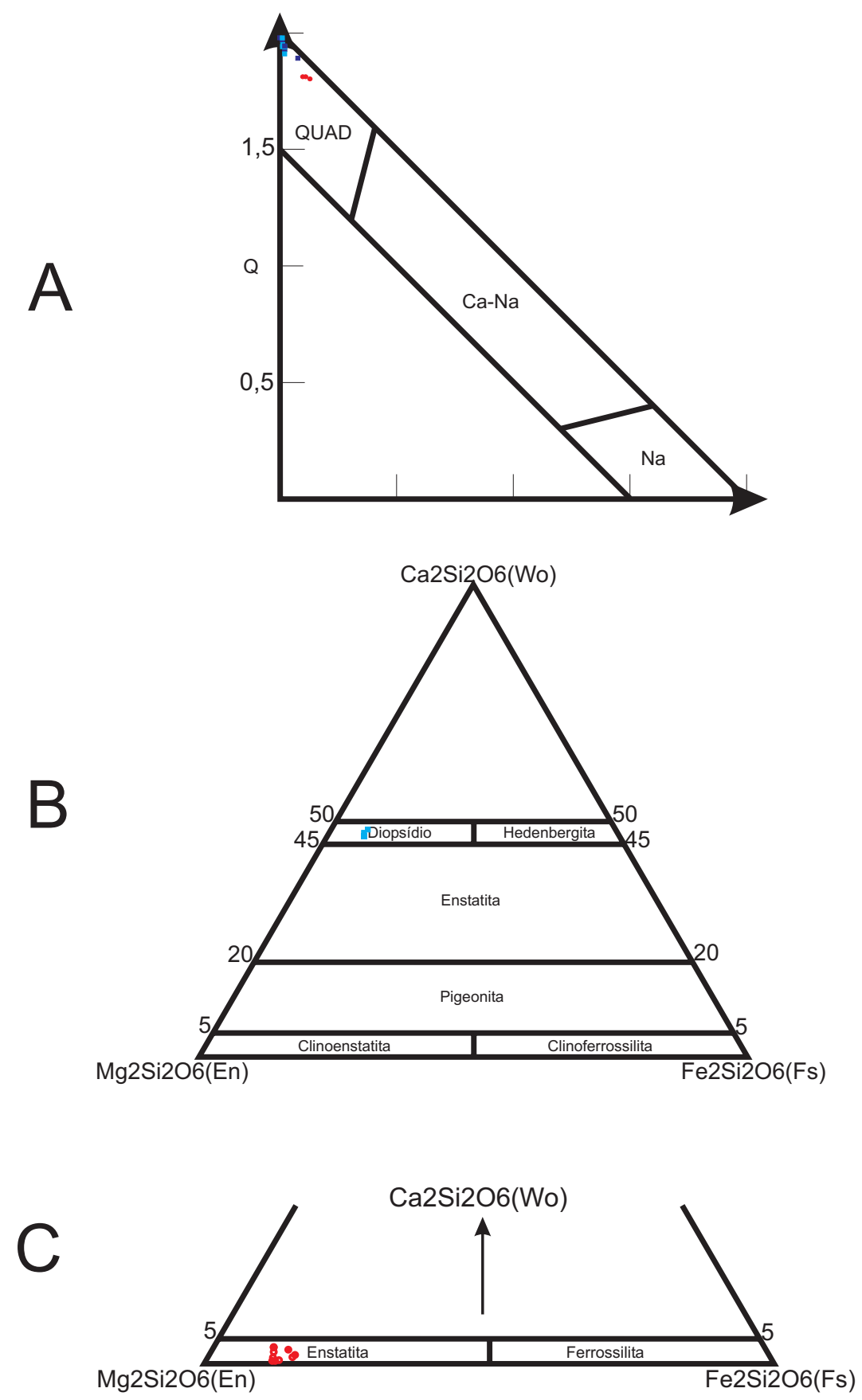

\section{LEGENDA}

macrocristais borda

macrocristais núcleo

xenólito piroxenítico

Figura 25 - A: Diagrama de classificação de piroxênios segundo Morimoto (1990), onde Q = Ca $+\mathrm{Mg}+\mathrm{Fe} 2$ e $\mathrm{J}=2 \mathrm{Na}$; B: Diagrama ternário de classificação de clinopiroxênios (En - Fs - Wo), onde En $=100 \mathrm{Mg} /(\mathrm{Ca}+\mathrm{Mg}$ $+\mathrm{Fe} 2+\mathrm{Fe} 3+\mathrm{Mn}+\mathrm{Na}), \mathrm{Fs}=100(\mathrm{Fe} 2+\mathrm{Fe} 3+\mathrm{Mn}) /(\mathrm{Ca}+\mathrm{Mg}+\mathrm{Fe} 2+\mathrm{Fe} 3+\mathrm{Mn}+\mathrm{Na})$ e $\mathrm{Wo}=100 \mathrm{Ca} /(\mathrm{Ca}+$ $\mathrm{Mg}+\mathrm{Fe} 2+\mathrm{Fe} 3+\mathrm{Mn}+\mathrm{Na}) ; \mathrm{C}$ : Diagrama ternário de classificação de ortopiroxênios, onde En $=100 \mathrm{Mg} /$ $(\mathrm{Ca}+\mathrm{Mg}+\mathrm{Fe} 2+\mathrm{Fe} 3+\mathrm{Mn}+\mathrm{Na}), \mathrm{Fs}=100(\mathrm{Fe} 2+\mathrm{Fe} 3+\mathrm{Mn}) /(\mathrm{Ca}+\mathrm{Mg}+\mathrm{Fe} 2+\mathrm{Fe} 3+\mathrm{Mn}+\mathrm{Na}) \mathrm{e}$ $\mathrm{Wo}=100 \mathrm{Ca} /(\mathrm{Ca}+\mathrm{Mg}+\mathrm{Fe} 2+\mathrm{Fe} 3+\mathrm{Mn}+\mathrm{Na})$. 


\subsubsection{Ilmenita}

Foram realizadas 33 análises de ilmenitas que ocorrem como fenocristais $(0,1$ a $0,5 \mathrm{~mm}) \mathrm{e}$ cristais de matriz da rocha, e como cristais de xenólitos piroxeníticos e duníticos, tanto aqueles isolados como os inclusos em olivina. As análises acham-se representadas nas tabelas 9 e 10 .

No diagrama (Figura 26) com os membros finais geikielita (Ge), ilmenita (Il) e hematita (He), os resultados indicam uma composição relativamente restrita para todos os cristais analisados, com variações de Ge entre 28 e 43\%, Il entre 47 e 52\% e He entre 13 e 27\%. No entanto, nota-se que as bordas dos fenocristais são levemente mais enriquecidas de $\mathrm{Mg}$ em relação aos respectivos núcleos, enquanto que alguns cristais da matriz se apresentam mais enriquecidos em $\mathrm{Mg}$ ou $\mathrm{Fe}$ e os de inclusão na olivina tendem ao vértice do Fe.

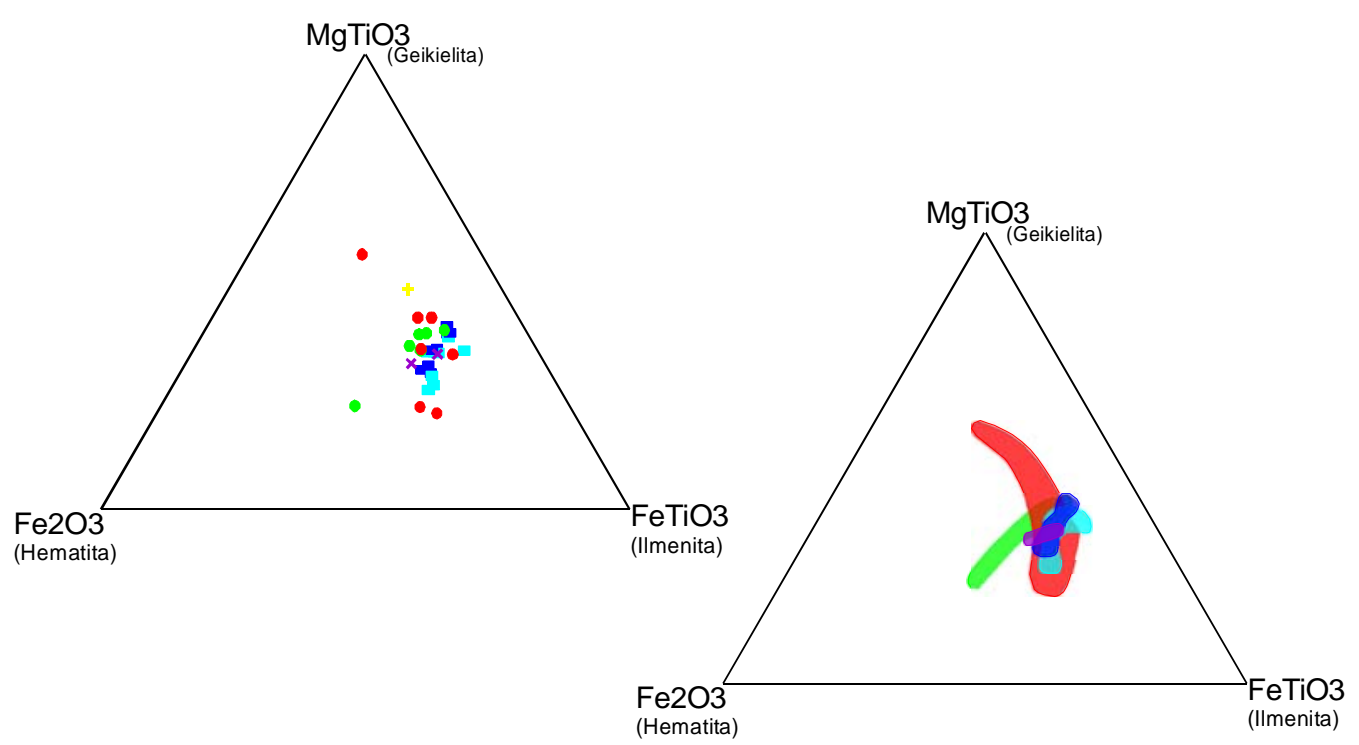

\section{LEGENDA}

Fenocristal - borda

Fenocristal - núcleo

X Xenólito piroxenítico

Xenólito dunítico

Incluso em olivina

Matriz

Figura 26. Composição de ilmenitas (mol\% em peso) de Indaiá I em diagrama triangular $\mathrm{Fe}_{2} \mathrm{O}_{3}-\mathrm{MgTiO}_{3}-\mathrm{FeTiO}_{3}$. No lado direito, o diagrama apresenta os campos de variação das ilmenitas analisadas para os fenocristais, matriz, xenólito piroxenítico, xenólito dunítico e inclusões de olivina. 
Tabela 9 - Composição química de ilmenita de xenólitos piroxeníticos e duníticos, de inclusões em olivina e dispersos na matriz. Obs: N, núcleo do grão; Pirox - xenólito piroxenítico ; Dun - xenólito dunítico; - abaixo do limite de detecção.

\begin{tabular}{|c|c|c|c|c|c|c|c|c|c|c|c|c|c|c|c|c|c|}
\hline & \multicolumn{2}{|c|}{ Pirox } & \multicolumn{7}{|c|}{ Inclusão de olivina } & \multicolumn{7}{|c|}{ Matriz } & Dun \\
\hline Grão & 01 & 02 & 01 & 02 & 03 & 04 & 05 & 06 & 07 & 01 & 02 & 03 & 04 & 05 & 06 & 07 & 01 \\
\hline Localização & $\mathrm{N}$ & $\mathrm{N}$ & $\mathrm{N}$ & $\mathrm{N}$ & $\mathrm{N}$ & $\mathrm{N}$ & $\mathrm{N}$ & $\mathrm{N}$ & $\mathrm{N}$ & $\mathrm{N}$ & $\mathrm{N}$ & $\mathrm{N}$ & $\mathrm{N}$ & $\mathrm{N}$ & $\mathrm{N}$ & $\mathrm{N}$ & $\mathrm{N}$ \\
\hline $\mathrm{SiO}_{2}$ & - & - & 0,07 & 0,01 & 0,05 & 0,06 & - & 0,04 & 0,01 & 0,05 & - & - & 0,01 & - & - & 0,01 & 0,04 \\
\hline $\mathrm{TiO}_{2}$ & 47,39 & 49,64 & 47,10 & 40,16 & 50,12 & 49,95 & 49,06 & 49,89 & 49,09 & 45,37 & 46,63 & 51,59 & 50,35 & 48,90 & 50,61 & 51,08 & 50,09 \\
\hline $\mathrm{Al}_{2} \mathrm{O}_{3}$ & 0,06 & 0,15 & 0,06 & 0,01 & 0,08 & 0,06 & 0,07 & 0,05 & 0,05 & 0,03 & 0,02 & 0,05 & 0,08 & 0,05 & 0,10 & 0,07 & 0,06 \\
\hline $\mathrm{Cr}_{2} \mathrm{O}_{3}$ & 1,13 & 2,30 & 1,70 & 1,60 & 3,25 & 2,63 & 1,37 & 1,24 & 1,19 & 1,12 & 1,05 & 1,08 & 1,57 & 1,64 & 0,34 & 1,72 & 2,77 \\
\hline $\mathrm{FeO}_{\mathrm{T}}$ & 39,80 & 35,84 & 34,56 & 46,19 & 32,88 & 34,23 & 36,49 & 34,79 & 37,08 & 43,39 & 44,00 & 31,46 & 31,16 & 34,82 & 35,28 & 25,03 & 28,18 \\
\hline $\mathrm{MnO}$ & 0,42 & 0,47 & 0,39 & 0,32 & 0,64 & 0,39 & 0,44 & 0,52 & 0,49 & 0,28 & 0,42 & 0,66 & 0,62 & 0,55 & 0,57 & 0,88 & 0,66 \\
\hline $\mathrm{MgO}$ & 10,00 & 10,30 & 11,24 & 7,23 & 12,12 & 10,94 & 10,95 & 11,87 & 10,66 & 7,24 & 6,64 & 13,03 & 13,17 & 11,10 & 10,34 & 18,32 & 14,56 \\
\hline $\mathrm{CaO}$ & 0,20 & 0,03 & 0,03 & 0,02 & 0,05 & 0,07 & - & 0,08 & 0,05 & 0,04 & 0,01 & 0,50 & 0,16 & 0,03 & 0,10 & 0,79 & 0,19 \\
\hline $\mathrm{Nb}_{2} \mathrm{O}_{5}$ & 0,37 & 0,26 & 0,41 & 0,70 & 0,26 & 0,15 & 0,33 & 0,42 & 0,40 & 0,41 & 0,37 & 0,16 & 0,11 & 0,23 & 0,07 & 0,11 & 0,18 \\
\hline $\mathrm{FeO}$ & 23,43 & 24,51 & 21,02 & 21,94 & 21,17 & 23,67 & 23,37 & 22,38 & 23,89 & 26,96 & 29,05 & 21,27 & 20,16 & 22,73 & 26,13 & 10,50 & 16,84 \\
\hline $\mathrm{Fe}_{2} \mathrm{O}_{3}$ & 18,17 & 12,58 & 15,03 & 26,92 & 13,00 & 11,73 & 14,56 & 13,77 & 14,64 & 18,24 & 16,59 & 11,31 & 12,21 & 13,41 & 10,16 & 16,12 & 12,59 \\
\hline Total & 101,16 & 100,24 & 97,03 & 98,91 & 100,73 & 99,65 & 100,15 & 100,27 & 100,46 & 99,74 & 100,78 & 99,65 & 98,42 & 98,64 & 98,41 & 99,61 & 97,97 \\
\hline
\end{tabular}

Fórmula Estrutural calculada na base de 06 oxigênios

\begin{tabular}{|c|c|c|c|c|c|c|c|c|c|c|c|c|c|c|c|c|c|}
\hline \multicolumn{18}{|c|}{ Fórmula Estrutural calculada na base de 06 oxigênios } \\
\hline $\mathrm{Si}$ & - & - & 0,003 & - & 0,002 & 0,003 & - & 0,002 & - & 0,002 & - & - & - & - & - & 0,001 & 0,002 \\
\hline $\mathrm{Ti}$ & 1,662 & 1,749 & 1,701 & 1,476 & 1,736 & 1,761 & 1,724 & 1,739 & 1,724 & 1,647 & 1,682 & 1,789 & 1,765 & 1,739 & 1,810 & 1,708 & 1,747 \\
\hline $\mathrm{Al}$ & 0,003 & 0,008 & 0,003 & 0,001 & 0,004 & 0,003 & 0,004 & 0,003 & 0,003 & 0,002 & 0,001 & 0,003 & 0,004 & 0,003 & 0,005 & 0,004 & 0,003 \\
\hline $\mathrm{Cr}$ & 0,042 & 0,085 & 0,065 & 0,062 & 0,118 & 0,098 & 0,051 & 0,046 & 0,044 & 0,043 & 0,040 & 0,039 & 0,058 & 0,061 & 0,013 & 0,060 & 0,102 \\
\hline $\mathrm{Fe}^{2+}$ & 0,914 & 0,960 & 0,844 & 0,896 & 0,815 & 0,928 & 0,913 & 0,868 & 0,933 & 1,088 & 1,166 & 0,820 & 0,786 & 0,899 & 1,039 & 0,390 & 0,653 \\
\hline $\mathrm{Fe}^{3+}$ & 0,650 & 0,452 & 0,554 & 1,009 & 0,459 & 0,422 & 0,522 & 0,489 & 0,524 & 0,675 & 0,611 & 0,400 & 0,436 & 0,487 & 0,370 & 0,550 & 0,448 \\
\hline $\mathrm{Mn}$ & 017 & 0,019 & 0,016 & 0,013 & 0,025 & 0,016 & 0,017 & 0,020 & 0,019 & 0,011 & 0,017 & 0,026 & 0,024 & 0,022 & 0,023 & 0,033 & 0,026 \\
\hline $\mathrm{Mg}$ & 0,695 & 0,719 & 0,804 & 0,526 & 0,832 & 0,764 & 0,762 & 0,820 & 0,742 & 0,521 & 0,475 & 0,896 & 0,915 & 0,782 & 0,733 & 1,214 & 1,006 \\
\hline $\mathrm{Ca}$ & & & & & 0,002 & & - & 0,004 & 0,003 & 0,002 & - & 0,025 & 0,008 & 0,001 & 0,005 & 0,038 & 0,009 \\
\hline $\mathrm{Nb}$ & 0,008 & 0,005 & 0,009 & 0,015 & 0,005 & 0,003 & 0,007 & 0,009 & 0,008 & 0,009 & 0,008 & 0,003 & 0,002 & 0,005 & 0,001 & 0,002 & 0,004 \\
\hline \multirow[t]{2}{*}{ Cátions } & 4,000 & 4,000 & 4,000 & 4,000 & 4,000 & 4,000 & 4,000 & 4,000 & 4,000 & 4,000 & 4,000 & 4,000 & 4,000 & 4,000 & 4,000 & 4,000 & 4,000 \\
\hline & \multicolumn{17}{|c|}{ Componentes Moleculares (\%) } \\
\hline $\mathrm{Al}_{2} \mathrm{O}_{3}$ & 0,07 & 0,19 & 0,07 & 0,01 & 0,10 & 0,08 & 0,08 & 0,06 & 0,07 & 0,04 & 0,02 & 0,06 & 0,10 & 0,06 & 0,12 & 0,09 & 0,07 \\
\hline $\mathrm{Cr}_{2} \mathrm{O}_{3}$ & 0,90 & 1,94 & 1,43 & 1,25 & 2,70 & 2,24 & 1,13 & 1,02 & 0,97 & 0,92 & 0,87 & 0,91 & 1,32 & 1,38 & 0,29 & 1,36 & 2,32 \\
\hline $\mathrm{Nb}_{2} \mathrm{O}_{5}$ & 0,17 & 0,12 & 0,20 & 0,31 & 0,12 & 0,07 & 0,16 & 0,20 & 0,19 & 0,19 & 0,18 & 0,08 & 0,05 & 0,11 & 0,03 & 0,05 & 0,09 \\
\hline Hematita & 26,66 & 18,24 & 22,92 & 39,02 & 18,01 & 16,91 & 21,86 & 20,60 & 22,02 & 27,93 & 25,55 & 16,29 & 18,06 & 20,26 & 16,35 & 21,60 & 17,66 \\
\hline Pirofanita & 0,73 & 0,85 & 0,70 & 0,54 & 1,13 & 0,72 & 0,78 & 0,92 & 0,86 & 0,49 & 0,74 & & 1,11 & 1,00 & 1,05 & 1,49 & 1,19 \\
\hline Geikielita & 30,21 & 32,70 & 35,65 & 21,19 & 37,89 & 35,04 & 33,95 & 36,84 & 33,03 & 22,42 & 20,72 & 41,38 & 41,70 & 35,16 & 33,70 & 54,67 & 46,00 \\
\hline Ilmenita & 41,27 & 45,96 & 39,03 & 37,68 & 40,05 & 44,95 & 42,05 & 40,36 & 42,87 & 48,01 & 51,93 & 40,08 & 37,66 & 42,03 & 48,44 & 20,74 & 32,67 \\
\hline
\end{tabular}


Tabela 10 - Composição química de fenocristais de ilmenitas de Indaiá I. Obs: N, núcleo do grão; abaixo do limite de detecção.

$$
\text { Grão }
$$

$$
01
$$
02 03 05 07

\begin{tabular}{|c|c|c|c|c|c|c|c|c|c|c|c|c|c|c|c|c|}
\hline Localização & $\mathrm{N}$ & B & $\mathrm{N}$ & $\mathrm{B}$ & $\mathrm{N}$ & $\mathrm{B}$ & $\mathrm{N}$ & B & $\mathrm{N}$ & B & $\mathrm{N}$ & $\mathrm{B}$ & $\mathrm{N}$ & B & $\mathrm{N}$ & $\mathrm{B}$ \\
\hline $\mathrm{SiO}_{2}$ & - & - & 0,05 & 0,01 & 0,02 & 0,02 & 0,05 & - & 0,05 & - & - & - & - & 0,04 & 0,06 & 0,05 \\
\hline $\mathrm{TiO}_{2}$ & 48,94 & 50,23 & 51,02 & 50,86 & 50,84 & 51,23 & 46,04 & 48,20 & 48,03 & 50,44 & 48,24 & 48,36 & 47,00 & 47,98 & 47,44 & 47,51 \\
\hline $\mathrm{Al}_{2} \mathrm{O}_{3}$ & 0,09 & 0,10 & 0,08 & 0,05 & 0,02 & 0,09 & 0,11 & 0,07 & 0,28 & 0,11 & 0,05 & 0,06 & 0,02 & 0,01 & 0,15 & 0,36 \\
\hline $\mathrm{Cr}_{2} \mathrm{O}_{3}$ & 1,50 & 1,93 & 2,11 & 1,98 & 2,07 & 2,36 & 1,86 & 2,03 & 5,06 & 4,04 & 2,50 & 2,74 & 1,53 & 1,48 & 1,93 & 1,34 \\
\hline $\mathrm{FeO}_{\mathrm{T}}$ & 35,61 & 34,58 & 33,45 & 31,97 & 33,23 & 32,33 & 38,80 & 36,87 & 34,79 & 31,62 & 34,53 & 34,02 & 39,60 & 38,41 & 39,13 & 38,29 \\
\hline $\mathrm{MnO}$ & 0,34 & 0,50 & 0,36 & 0,51 & 0,46 & 0,58 & 0,34 & 0,48 & 0,26 & 0,38 & 0,31 & 0,39 & 0,35 & 0,44 & 0,30 & 0,37 \\
\hline $\mathrm{MgO}$ & 10,20 & 10,99 & 10,82 & 11,56 & 11,30 & 11,95 & 8,29 & 9,93 & 10,69 & 11,47 & 10,16 & 10,71 & 8,43 & 9,36 & 8,85 & 9,65 \\
\hline $\mathrm{CaO}$ & 0,04 & 0,32 & 0,03 & 0,10 & 0,11 & 0,11 & 0,02 & 0,08 & - & 0,06 & 0,05 & 0,02 & 0,02 & 0,09 & 0,02 & 0,19 \\
\hline $\mathrm{Nb}_{2} \mathrm{O}_{5}$ & 0,25 & 0,28 & 0,15 & 0,26 & 0,29 & 0,30 & 0,25 & 0,16 & 1,08 & 0,14 & 0,15 & 0,19 & 0,23 & 0,23 & 0,20 & 0,14 \\
\hline Total & 96,96 & 98,93 & 98,07 & 97,29 & 98,33 & 98,97 & 95,75 & 97,82 & 100,26 & 98,25 & 95,99 & 96,48 & 97,19 & 98,02 & 98,07 & 97,91 \\
\hline $\mathrm{FeO}$ & 24,60 & 23,60 & 25,18 & 23,47 & 23,92 & 22,82 & 25,30 & 24,01 & 21,06 & 22,43 & 23,64 & 22,61 & 26,06 & 25,20 & 25,56 & 24,03 \\
\hline $\mathrm{Fe}_{2} \mathrm{O}_{3}$ & 12,22 & 12,19 & 9,18 & 9,43 & 10,33 & 10,56 & 14,99 & 14,26 & 15,24 & 10,19 & 12,09 & 12,67 & 15,03 & 14,66 & 15,06 & 15,82 \\
\hline Total & 98,17 & 100,14 & 98,98 & 98,23 & 99,36 & 100,01 & 97,24 & 99,23 & 101,77 & 99,26 & 97,19 & 97,73 & 98,67 & 99,47 & 99,56 & 99,47 \\
\hline & \multicolumn{16}{|c|}{ Fórmula Estrutural calculada na base de 06 oxigênios } \\
\hline $\mathrm{Si}$ & - & - & 0,002 & 0,001 & 0,001 & 0,001 & 0,002 & - & 0,002 & - & - & - & - & 0,002 & 0,003 & 0,002 \\
\hline $\mathrm{Ti}$ & 1,759 & 1,761 & 1,810 & 1,808 & 1,792 & 1,787 & 1,695 & 1,720 & 1,671 & 1,777 & 1,751 & 1,740 & 1,706 & 1,716 & 1,700 & 1,692 \\
\hline $\mathrm{Al}$ & 0,005 & 0,006 & 0,005 & 0,003 & 0,001 & 0,005 & 0,007 & 0,004 & 0,015 & 0,006 & 0,003 & 0,004 & 0,001 & - & 0,008 & 0,020 \\
\hline $\mathrm{Cr}$ & 0,057 & 0,071 & 0,079 & 0,074 & 0,077 & 0,086 & 0,072 & 0,076 & 0,185 & 0,150 & 0,095 & 0,103 & 0,058 & 0,055 & 0,073 & 0,050 \\
\hline $\mathrm{Fe}^{2+}$ & 0,983 & 0,920 & 0,993 & 0,928 & 0,938 & 0,885 & 1,036 & 0,953 & 0,815 & 0,879 & 0,954 & 0,904 & 1,052 & 1,002 & 1,019 & 0,952 \\
\hline $\mathrm{Fe}^{3+}$ & 0,448 & 0,436 & 0,332 & 0,342 & 0,372 & 0,376 & 0,563 & 0,519 & 0,541 & 0,366 & 0,447 & 0,465 & 0,556 & 0,535 & 0,551 & 0,575 \\
\hline $\mathrm{Mn}$ & 0,014 & 0,020 & 0,014 & 0,020 & 0,018 & 0,023 & 0,014 & 0,019 & 0,010 & 0,015 & 0,013 & 0,016 & 0,014 & 0,018 & 0,012 & 0,015 \\
\hline $\mathrm{Mg}$ & 0,726 & 0,764 & 0,761 & 0,815 & 0,790 & 0,826 & 0,605 & 0,702 & 0,737 & 0,801 & 0,731 & 0,763 & 0,606 & 0,663 & 0,629 & 0,681 \\
\hline $\mathrm{Ca}$ & 0,002 & 0,016 & 0,001 & 0,005 & 0,006 & 0,005 & 0,001 & 0,004 & - & 0,003 & 0,003 & 0,001 & 0,001 & 0,004 & 0,001 & 0,010 \\
\hline $\mathrm{Nb}$ & 0,005 & 0,006 & 0,003 & 0,005 & 0,006 & 0,006 & 0,006 & 0,004 & 0,023 & 0,003 & 0,003 & 0,004 & 0,005 & 0,005 & 0,004 & 0,003 \\
\hline \multirow[t]{2}{*}{ Cátions } & 4,000 & 4,000 & 4,000 & 4,000 & 4,000 & 4,000 & 4,000 & 4,000 & 4,000 & 4,000 & 4,000 & 4,000 & 4,000 & 4,000 & 4,000 & 4,000 \\
\hline & \multicolumn{16}{|c|}{ Componentes Moleculares (\%) } \\
\hline $\mathrm{Al}_{2} \mathrm{O}_{3}$ & 0,11 & 0,13 & 0,11 & 0,06 & 0,02 & 0,11 & 0,14 & 0,09 & 0,35 & 0,14 & 0,07 & 0,08 & 0,03 & 0,01 & 0,18 & 0,45 \\
\hline $\mathrm{Cr}_{2} \mathrm{O}_{3}$ & 1,29 & 1,63 & 1,84 & 1,72 & 1,78 & 2,00 & 1,59 & 1,70 & 4,20 & 3,50 & 2,17 & 2,35 & 1,29 & 1,23 & 1,62 & 1,11 \\
\hline $\mathrm{Nb}_{2} \mathrm{O}_{5}$ & 0,02 & 0,02 & 0,01 & 0,02 & 0,03 & 0,03 & 0,02 & 0,01 & 0,09 & 0,01 & 0,01 & 0,02 & 0,02 & 0,02 & 0,02 & 0,01 \\
\hline Hematita & 18,72 & 17,37 & 13,55 & 13,85 & 15,08 & 14,97 & 23,14 & 21,19 & 19,58 & 13,30 & 17,96 & 18,55 & 23,15 & 22,35 & 22,65 & 23,51 \\
\hline Pirofanita & 0,62 & 0,90 & 0,66 & 0,95 & 0,84 & 1,05 & 0,62 & 0,86 & 0,47 & 0,71 & 0,58 & 0,71 & 0,64 & 0,78 & 0,54 & 0,66 \\
\hline Geikielita & 32,98 & 35,07 & 35,51 & 38,01 & 36,62 & 38,32 & 26,79 & 31,43 & 33,42 & 37,44 & 33,29 & 34,67 & 26,83 & 29,53 & 27,92 & 30,18 \\
\hline Ilmenita & 46,26 & 44,87 & 48,32 & 45,39 & 45,64 & 43,52 & 47,69 & 44,71 & 41,89 & 44,91 & 45,92 & 43,63 & 48,04 & 46,08 & 47,07 & 44,08 \\
\hline
\end{tabular}
08 


\subsubsection{Grupo dos Espinélios}

Foram realizadas 18 análises em minerais do grupo do espinélio, sendo 12 em cristais de magnetita, 4 em cromita e 2 em espinélio. As análises foram organizadas de acordo com o membro final predominante. Os resultados obtidos estão reunidos nas tabelas 11 e 12, juntamente com a fórmula estrutural e as proporções dos componentes moleculares.

Tabela 11 - Composição química de minerais do grupo dos espinélios - cromita e espinélios de Indaiá I. Obs: abaixo do limite de deteç̧ão; incl ol - inclusão de olivina.

\begin{tabular}{|c|c|c|c|c|c|c|}
\hline \multirow{3}{*}{$\begin{array}{c}\text { Grão } \\
\text { Localização }\end{array}$} & \multicolumn{4}{|c|}{ CROMITA } & \multicolumn{2}{|c|}{ ESPINÉLIO } \\
\hline & 01 & 01 & 02 & 01 & 01 & 01 \\
\hline & Matriz & \multicolumn{2}{|c|}{ Lapilli } & Carbonatítico & Matriz & Incl ol \\
\hline $\mathrm{SiO}_{2}$ & 0,06 & 0,12 & 0,06 & 0,11 & 0,02 & 0,04 \\
\hline $\mathrm{TiO}_{2}$ & 4,91 & 4,09 & 4,66 & 4,78 & 0,20 & 0,06 \\
\hline $\mathrm{Al}_{2} \mathrm{O}_{3}$ & 5,22 & 4,36 & 5,71 & 5,67 & 35,61 & 31,60 \\
\hline $\mathrm{Cr}_{2} \mathrm{O}_{3}$ & 47,66 & 50,06 & 48,87 & 48,26 & 33,52 & 37,82 \\
\hline $\mathrm{FeO}$ & 28,02 & 28,11 & 27,14 & 26,52 & 16,07 & 15,15 \\
\hline $\mathrm{MnO}$ & 0,26 & 0,46 & 0,18 & 0,25 & 0,11 & 0,07 \\
\hline $\mathrm{MgO}$ & 11,71 & 11,72 & 12,08 & 12,41 & 14,79 & 15,17 \\
\hline $\mathrm{CaO}$ & 0,20 & 0,25 & 0,41 & 0,17 & 0,05 & 0,03 \\
\hline $\mathrm{Nb}_{2} \mathrm{O}_{5}$ & 0,04 & - & 0,20 & - & - & - \\
\hline Total & 98,10 & 99,18 & 99,31 & 98,16 & 100,36 & 99,96 \\
\hline $\mathrm{FeO}$ & 18,71 & 18,04 & 18,11 & 17,72 & 15,24 & 13,88 \\
\hline $\mathrm{Fe}_{2} \mathrm{O}_{3}$ & 10,35 & 11,19 & 10,03 & 9,77 & 0,92 & 1,41 \\
\hline \multirow[t]{2}{*}{ Total } & 99,13 & 100,30 & 100,31 & 99,13 & 100,45 & 100,10 \\
\hline & \multicolumn{6}{|c|}{ Fórmula Estrutural calculada na base de 32 oxigênios } \\
\hline $\mathrm{Si}$ & 0,016 & 0,033 & 0,016 & 0,030 & 0,003 & 0,010 \\
\hline $\mathrm{Ti}$ & 0,996 & 0,823 & 0,929 & 0,961 & 0,035 & 0,011 \\
\hline $\mathrm{Al}$ & 1,658 & 1,375 & 1,784 & 1,786 & 9,660 & 8,709 \\
\hline $\mathrm{Cr}$ & 10,152 & 10,588 & 10,251 & 10,203 & 6,100 & 6,993 \\
\hline $\mathrm{Fe}^{2+}$ & 4,214 & 4,036 & 4,019 & 3,963 & 2,934 & 2,715 \\
\hline $\mathrm{Fe}^{3+}$ & 2,139 & 2,296 & 2,042 & 2,004 & 0,162 & 0,252 \\
\hline $\mathrm{Mn}$ & 0,060 & 0,105 & 0,041 & 0,056 & 0,020 & 0,014 \\
\hline $\mathrm{Mg}$ & 4,703 & 4,673 & 4,778 & 4,947 & 5,074 & 5,288 \\
\hline $\mathrm{Ca}$ & 0,057 & 0,071 & 0,117 & 0,050 & 0,012 & 0,008 \\
\hline $\mathrm{Nb}$ & 0,005 & - & 0,024 & - & - & - \\
\hline \multirow[t]{2}{*}{ Cátions } & 24,000 & 24,000 & 24,000 & 24,000 & 24,000 & 24,000 \\
\hline & \multicolumn{6}{|c|}{ Membros finais } \\
\hline Espinélio & 16,80 & 14,05 & 18,06 & 18,13 & 61,48 & 57,94 \\
\hline Hercinita & - & - & - & - & - & - \\
\hline Magnetita & 21,67 & 23,45 & 20,66 & 20,34 & 1,03 & 1,68 \\
\hline Mg-cromita & 8,73 & 12,85 & 11,20 & 11,55 & 1,55 & 6,21 \\
\hline Mn-cromita & - & - & - & - & - & - \\
\hline Cromita & 42,70 & 41,24 & 40,67 & 40,22 & 35,71 & 34,10 \\
\hline Ulvospinélio & - & - & - & - & 0,22 & 0,07 \\
\hline Mg-ulvospinélio & 10,09 & 8,41 & 9,40 & 9,75 & 0,00 & 0,00 \\
\hline Mn-ulvospinélio & - & - & - & - & - & - \\
\hline
\end{tabular}


Tabela 12 - Composição química de minerais do grupo dos espinélios - magnetitas de Indaiá I. Obs: incl ol inclusão em olivina; - abaixo do limite de detecção.

\begin{tabular}{|c|c|c|c|c|c|c|c|c|c|c|c|c|}
\hline $\begin{array}{c}\text { Grão } \\
\text { Localização }\end{array}$ & 01 & 02 & $\begin{array}{c}03 \\
\text { Matriz } \\
\end{array}$ & 04 & 05 & 01 & $\begin{array}{c}02 \\
\text { Lapilli } \\
\end{array}$ & 03 & $\begin{array}{l}01 \\
\text { Pirox } \\
\end{array}$ & $\begin{array}{r}02 \\
\text { ítico } \\
\end{array}$ & $\begin{array}{c}01 \\
\text { incl em ol } \\
\end{array}$ & $\begin{array}{c}01 \\
\text { Borda de ol } \\
\end{array}$ \\
\hline $\mathrm{SiO}_{2}$ & 0,07 & 0,11 & 0,08 & 1,81 & 0,09 & 0,03 & 0,06 & - & 0,02 & 1,11 & 0,14 & 0,11 \\
\hline $\mathrm{TiO}_{2}$ & 15,77 & 10,66 & 13,99 & 20,20 & 16,08 & 10,08 & 12,37 & 10,50 & 12,86 & 16,06 & 4,09 & 11,48 \\
\hline $\mathrm{Al}_{2} \mathrm{O}_{3}$ & 2,24 & 2,11 & 1,37 & 1,17 & 1,19 & 5,11 & 3,77 & 4,16 & 1,13 & 1,08 & 0,21 & 4,73 \\
\hline $\mathrm{Cr}_{2} \mathrm{O}_{3}$ & 0,95 & 0,02 & 0,33 & 3,47 & 1,18 & 21,06 & - & - & 22,78 & 1,72 & 0,05 & 0,27 \\
\hline $\mathrm{FeO}$ & 59,86 & 66,11 & 68,60 & 50,70 & 59,62 & 43,71 & 62,46 & 64,73 & 45,00 & 57,03 & 85,49 & 63,86 \\
\hline $\mathrm{MnO}$ & 1,20 & 1,14 & 1,05 & 1,32 & 1,35 & 1,00 & 1,08 & 0,91 & 1,07 & 1,39 & 0,28 & 1,04 \\
\hline $\mathrm{MgO}$ & 15,38 & 13,03 & 10,52 & 16,15 & 16,19 & 14,02 & 14,62 & 13,01 & 14,51 & 14,48 & 2,76 & 12,90 \\
\hline $\mathrm{CaO}$ & 0,48 & 0,24 & 0,22 & 1,27 & 0,41 & 0,39 & 0,32 & 0,46 & 0,24 & 2,12 & 0,04 & 0,09 \\
\hline $\mathrm{Nb}_{2} \mathrm{O}_{5}$ & - & - & - & 0,02 & 0,04 & - & 0,01 & 0,04 & 0,04 & 0,04 & 0,04 & - \\
\hline Total & 95,95 & 93,42 & 96,15 & 96,12 & 96,14 & 95,40 & 94,69 & 93,82 & 97,65 & 95,02 & 93,09 & 94,46 \\
\hline $\mathrm{FeO}$ & 21,54 & 20,40 & 27,89 & 24,97 & 20,46 & 18,55 & 19,95 & 20,49 & 20,46 & 21,78 & 31,25 & 22,21 \\
\hline $\mathrm{Fe}_{2} \mathrm{O}_{3}$ & 42,57 & 50,79 & 45,23 & 28,59 & 43,50 & 27,96 & 47,23 & 49,16 & 27,27 & 39,17 & 60,26 & 46,27 \\
\hline Total & 100,20 & 98,50 & 100,68 & 98,98 & 100,49 & 98,20 & 99,42 & 98,73 & 100,38 & 98,94 & 99,12 & 99,09 \\
\hline
\end{tabular}

Fórmula Estrutural calculada na base de 32 oxigênios

\begin{tabular}{|c|c|c|c|c|c|c|c|c|c|c|c|c|}
\hline \multirow[b]{2}{*}{$\mathrm{Si}$} & \multicolumn{12}{|c|}{ (1) } \\
\hline & 0,019 & 0,029 & 0,021 & 0,480 & 0,024 & 0,008 & 0,016 & - & 0,006 & 0,298 & 0,042 & 0,029 \\
\hline $\mathrm{Ti}$ & 3,146 & 2,204 & 2,893 & 4,029 & 3,199 & 2,035 & 2,487 & 2,146 & 2,583 & 3,252 & 0,920 & 2,333 \\
\hline $\mathrm{Al}$ & 0,702 & 0,684 & 0,445 & 0,367 & 0,371 & 1,616 & 1,188 & 1,333 & 0,355 & 0,341 & 0,072 & 1,505 \\
\hline $\mathrm{Cr}$ & 0,199 & 0,004 & 0,071 & 0,727 & 0,246 & 4,471 & - & - & 4,809 & 0,366 & 0,011 & 0,058 \\
\hline $\mathrm{Fe}^{2+}$ & 4,781 & 4,690 & 6,413 & 5,538 & 4,527 & 4,165 & 4,461 & 4,657 & 4,569 & 4,905 & 7,815 & 5,021 \\
\hline $\mathrm{Fe}^{3+}$ & 8,663 & 10,711 & 9,538 & 5,815 & 8,826 & 5,756 & 9,685 & 10,246 & 5,586 & 8,090 & 13,820 & 9,593 \\
\hline $\mathrm{Mn}$ & 0,270 & 0,265 & 0,244 & 0,297 & 0,302 & 0,227 & 0,243 & 0,210 & 0,241 & 0,317 & 0,070 & 0,239 \\
\hline $\mathrm{Mg}$ & 6,084 & 5,341 & 4,312 & 6,384 & 6,383 & 5,612 & 5,825 & 5,269 & 5,776 & 5,814 & 1,231 & 5,196 \\
\hline $\mathrm{Ca}$ & 0,137 & 0,071 & 0,065 & 0,361 & 0,116 & 0,111 & 0,092 & 0,133 & 0,069 & 0,611 & 0,014 & 0,025 \\
\hline $\mathrm{Nb}$ & - & - & - & 0,002 & 0,005 & - & 0,002 & 0,005 & 0,005 & 0,005 & 0,006 & - \\
\hline Cátions & 24,000 & 24,000 & 24,000 & 24,000 & 24,000 & 24,000 & 24,000 & 24,000 & 24,000 & 24,000 & 24,000 & 24,000 \\
\hline
\end{tabular}

\begin{tabular}{|c|c|c|c|c|c|c|c|c|c|c|c|c|}
\hline \multirow[b]{2}{*}{ Espinélio } & \multicolumn{12}{|c|}{ Membros finais } \\
\hline & 5,43 & 5,03 & 3,23 & 2,99 & 2,93 & 11,13 & 8,90 & 9,71 & 2,50 & 2,73 & 0,47 & 11,07 \\
\hline Hercinita & - & - & - & - & - & - & - & - & - & - & - & - \\
\hline Magnetita & 66,98 & 78,74 & 69,27 & 47,46 & 69,74 & 39,64 & 72,49 & 74,65 & 39,28 & 64,83 & 90,47 & 70,53 \\
\hline Mg-cromita & 1,54 & 0,03 & 0,52 & 5,93 & 1,94 & 30,79 & - & - & 33,82 & 2,94 & 0,07 & 0,43 \\
\hline Mn-cromita & - & - & - & - & - & - & - & - & - & - & - & - \\
\hline Cromita & - & - & - & - & - & - & - & - & - & - & - & - \\
\hline Ulvospinélio & 3,47 & - & 11,94 & 21,46 & 0,90 & 8,86 & - & - & 12,49 & 6,89 & 5,92 & 1,65 \\
\hline Mg-ulvospinélio & 22,16 & 16,20 & 14,85 & 22,15 & 24,48 & 9,58 & 18,62 & 15,63 & 11,92 & 22,61 & 3,06 & 16,33 \\
\hline Mn-ulvospinélio & 0,42 & - & 0,19 & - & - & - & - & - & - & - & - & - \\
\hline
\end{tabular}

Os resultandos obtidos (Tabelas 11 e 12) indicam que os minerais do grupo dos espinélios analisados são representados pelos seguintes membros, considerando a fórmula estrutural média $\mathrm{XY}_{2} \mathrm{O}_{32}$ e a porcentagem média dos principais membros finais:

- Cromita: $\left(\mathrm{Mg}_{4,77} \mathrm{Fe}_{4,06}^{2+} \mathrm{Mn}_{0,07} \mathrm{Ca}_{0,07} \mathrm{Nb}_{0,01}\right) \quad\left(\mathrm{Si}_{0,01} \mathrm{Al}_{1,65} \mathrm{Cr}_{10,3} \mathrm{Fe}_{2,12}^{3+} \mathrm{Ti}_{0,93}\right)_{2,00} \mathrm{O}_{32} \quad$ ou $\mathrm{Es}_{16,8} \mathrm{Mag}_{30,9} \mathrm{Cr}_{52,3}$;

- Espinélio: $\left(\mathrm{Mg}_{5,18} \mathrm{Fe}^{2+}{ }_{2,82} \mathrm{Mn}_{0,02} \mathrm{Ca}_{0,01}\right) \quad\left(\mathrm{Si}_{0,02} \mathrm{Al}_{9,18} \mathrm{Cr}_{6,55} \mathrm{Fe}^{3+}{ }_{0,21} \mathrm{Ti}_{0,02}\right)_{2,00} \quad \mathrm{O}_{32} \quad$ ou $\mathrm{Es}_{59,7} \mathrm{Mag}_{1,5} \mathrm{Cr}_{38,8}$;

- Magnetita: $\quad\left(\mathrm{Mg}_{4,71} \mathrm{Fe}^{2+}{ }_{5,57} \mathrm{Mn}_{0,23} \mathrm{Ca}_{0,13}\right) \quad\left(\mathrm{Si}_{0,09} \mathrm{Al}_{0,67} \mathrm{Cr}_{2,05} \mathrm{Fe}^{3+}{ }_{8,06} \mathrm{Ti}_{2,47}\right)_{2,00} \quad \mathrm{O}_{32} \quad$ ou $\mathrm{Es}_{4,8} \mathrm{Mag}_{81,9} \mathrm{Cr}_{13,2}$. 
A deficiência dos íons $\mathrm{Fe}^{2+}$ e $\mathrm{Fe}^{3+}$ em todas as séries deste grupo é compensada pelo excesso de $\mathrm{Mg}$, Mn e Ca.

No diagrama ternário $\mathrm{Cr}-\mathrm{Al}-\left(\mathrm{Fe}^{2+}+2 \mathrm{Ti}\right)$, Figura 27 , observa-se a distribuição dos cristais de magnétita, cromitas e espinélios da intrusão I, onde se percebe variação máxima do membro $\mathrm{Al}$ - espinélio em torno de $20 \%$ e o caráter mantélico dos cristais de espinélios componentes da matriz e inseridos em cristais de olivina.

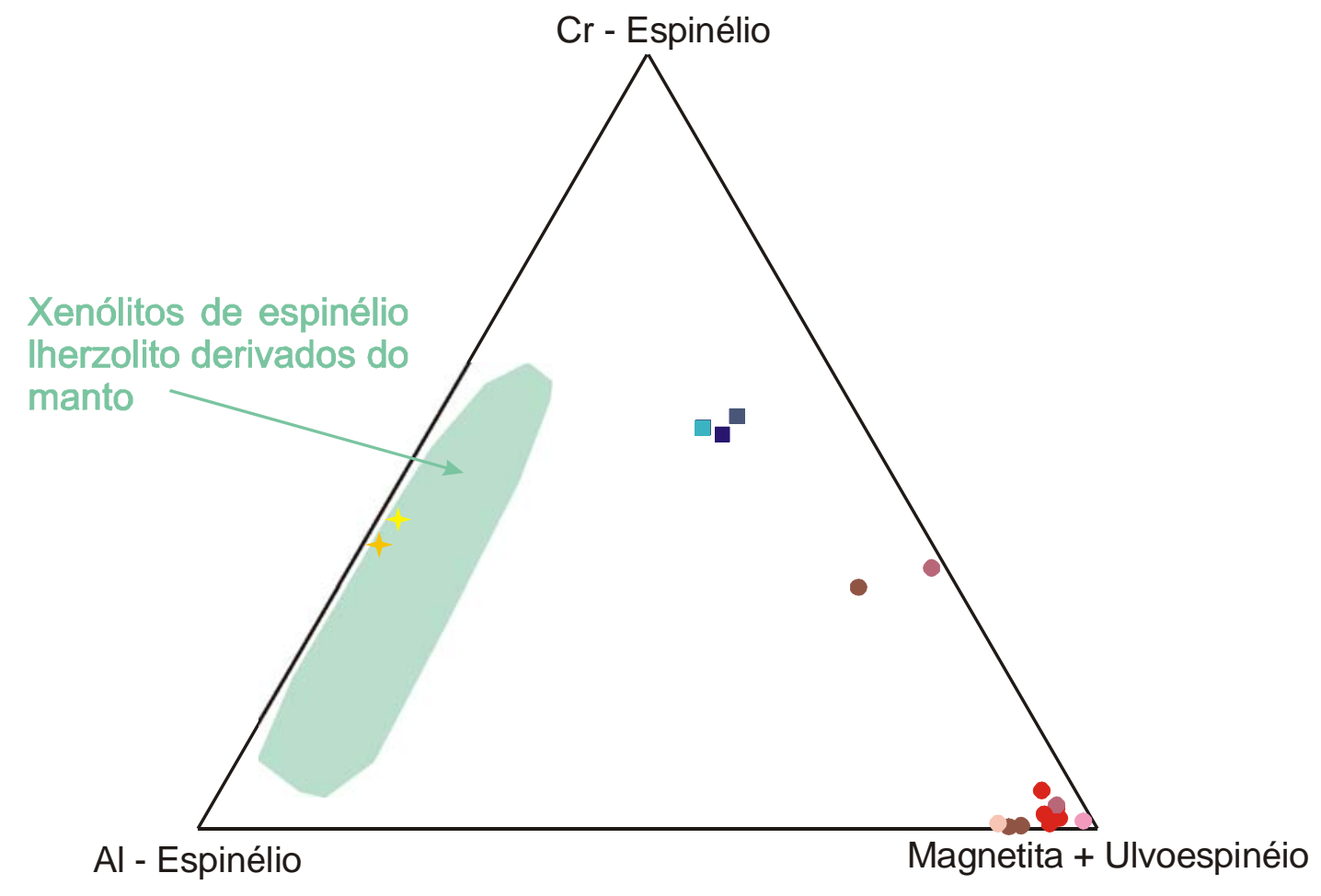

\section{LEGENDA}

Magnetita (matriz)

Magnetita (lapilli)

Magnetita (xenólito piroxenítico)

Magnetita (inclusa em olivina)

Magnetita (borda de olivina)

Figura 27. Diagrama $\mathrm{Cr}-\mathrm{Al}-\left(\mathrm{Fe}^{2+}+2 \mathrm{Ti}\right)$ para espinélios da intrusão Indaiá I. Modificado de Melluso et al., 2007. 


\subsubsection{Monticellita}

A monticellita foi caracterizada durante análise de olivinas, direcionando o alvo para seções de minerais presentes na matriz da rocha, com baixa birrefringência ou com bordas alteradas para carbonatos. Os resultados obtidos de 8 análises realizadas neste mineral estão reunidos nas tabelas 13 , juntos com a fórmula estrutural e as proporções dos componentes moleculares.

Tabela 13 - Composição química de monticellita em cristais da matriz das rochas de Indaiá I. Obs: N, núcleo do grão; - abaixo do limite de detecção.

\begin{tabular}{|c|c|c|c|c|c|c|c|c|}
\hline Grão & 01 & 02 & 03 & 04 & 05 & 06 & 07 & 08 \\
\hline Localização & $\mathrm{N}$ & $\mathrm{N}$ & $\mathrm{N}$ & $\mathrm{N}$ & $\mathrm{N}$ & $\mathrm{N}$ & $\mathrm{N}$ & $\mathrm{N}$ \\
\hline $\mathrm{SiO}_{2}$ & 37,12 & 37,24 & 37,23 & 37,00 & 37,30 & 36,69 & 37,39 & 35,79 \\
\hline $\mathrm{TiO}_{2}$ & 0,01 & - & 0,01 & - & 0,07 & 0,19 & 0,02 & 1,23 \\
\hline $\mathrm{Al}_{2} \mathrm{O}_{3}$ & 0,03 & 0,02 & 0,03 & 0,01 & 0,04 & 0,04 & 0,02 & 0,01 \\
\hline $\mathrm{FeO}$ & 3,29 & 3,05 & 3,30 & 3,42 & 2,16 & 3,09 & 2,12 & 3,83 \\
\hline $\mathrm{MnO}$ & 0,23 & 0,27 & 0,27 & 0,29 & 0,17 & 0,25 & 0,16 & 0,21 \\
\hline $\mathrm{MgO}$ & 23,38 & 23,22 & 23,57 & 23,35 & 24,63 & 23,43 & 23,93 & 22,33 \\
\hline $\mathrm{CaO}$ & 36,41 & 35,57 & 35,65 & 35,72 & 35,35 & 35,70 & 35,57 & 35,24 \\
\hline $\mathrm{Na}_{2} \mathrm{O}$ & 0,03 & 0,01 & 0,03 & 0,03 & 0,16 & 0,13 & 0,08 & 0,16 \\
\hline $\mathrm{K}_{2} \mathrm{O}$ & - & - & 0,02 & 0,04 & 0,03 & - & 0,02 & - \\
\hline $\mathrm{Cr}_{2} \mathrm{O}_{3}$ & 0,03 & 0,05 & 0,20 & 0,15 & - & 0,03 & - & 0,11 \\
\hline \multirow[t]{2}{*}{ Total } & 100,52 & 99,43 & 100,31 & 100,00 & 99,90 & 99,52 & 99,32 & 98,91 \\
\hline & \multicolumn{8}{|c|}{ Fórmula Estrutural calculada na base de 04 oxigênios } \\
\hline $\mathrm{Si}$ & 0,977 & 0,991 & 0,982 & 0,980 & 0,981 & 0,975 & 0,991 & 0,964 \\
\hline $\mathrm{Ti}$ & - & - & - & - & 0,001 & 0,004 & - & 0,025 \\
\hline $\mathrm{Al}$ & - & - & - & - & 0,001 & 0,001 & - & - \\
\hline $\mathrm{Fe}^{2+}$ & 0,072 & 0,068 & 0,073 & 0,076 & 0,047 & 0,069 & 0,047 & 0,086 \\
\hline $\mathrm{Mn}$ & 0,005 & 0,006 & 0,006 & 0,006 & 0,004 & 0,006 & 0,004 & 0,005 \\
\hline $\mathrm{Mg}$ & 0,917 & 0,921 & 0,927 & 0,921 & 0,965 & 0,927 & 0,945 & 0,897 \\
\hline $\mathrm{Ca}$ & 1,027 & 1,014 & 1,008 & 1,013 & 0,996 & 1,016 & 1,010 & 1,017 \\
\hline $\mathrm{Na}$ & 0,001 & - & 0,001 & 0,001 & 0,004 & 0,003 & 0,002 & 0,004 \\
\hline $\mathrm{K}$ & - & - & - & 0,001 & 0,001 & - & - & - \\
\hline $\mathrm{Cr}$ & - & 0,001 & 0,002 & 0,002 & - & - & - & 0,001 \\
\hline \multirow[t]{2}{*}{ Cations } & 3,000 & 3,000 & 3,000 & 3,000 & 3,000 & 3,000 & 3,000 & 3,000 \\
\hline & \multicolumn{8}{|c|}{ Membros Finais } \\
\hline $\mathrm{CaMgSiO} 4$ & 92,7 & 93,1 & 92,7 & 92,4 & 93,7 & 93,1 & 95,3 & 91,2 \\
\hline $\mathrm{CaFeSiO} 4$ & 7,3 & 6,9 & 7,3 & 7,6 & 4,7 & 6,9 & 4,7 & 8,8 \\
\hline $\mathrm{Mg}_{2} \mathrm{SiO} 4$ & 0,0 & 0,0 & 0,0 & 0,0 & 1,6 & 0,0 & 0,0 & 0,0 \\
\hline
\end{tabular}

São quatro os principais elementos constituintes da monticellita: $\mathrm{Ca}(0,996$ a 1,027 a.f.u.), $\operatorname{Mg}(0,897$ a 0.965 a.f.u.), Si (0,964 a 0,991 a.f.u.) e Fe (0,047 a 0,086 a.f.u.), os demais elementos ( $\mathrm{Ti}, \mathrm{Al}, \mathrm{Na}, \mathrm{K}$ e $\mathrm{Cr}$ ), quando detectados apresentam no máximo totais de 0,025 a.f.u. Observando as proporções moleculares dos membros finais denota que são monticellitas $(\mathrm{CaMgSiO} 4)$ relativamente puras, exibindo solução sólida entre kirschsteinita $(\mathrm{CaFeSiO} 4)$ na ordem de $6,8 \%$ e forsterita $\left(\mathrm{Mg}_{2} \mathrm{SiO} 4\right)$ em torno de $0,2 \%$. 


\subsubsection{Perovskita}

Foram realizadas 25 análises em cristais de perovskita, sempre em pontos localizados nos núcleos dos grãos, em virtude de seu tamanho reduzido. Os resultados obtidos acham-se reunidos na tabela 14, nas quais constam também as fórmulas estruturais calculadas na base de três oxigênios e as proporções dos componentes moleculares. Os dados químicos da perovskita foram locados no diagrama de fase da Figura 28 cujos extremos representam os membros finais dos principais minerais estudados.

As perovskitas têm uma estrutura ideal cúbica, podendo ser representada pela fórmula geral $\mathrm{ABO}_{3}$ (Deer et al., 1992). Entretanto, as perovskitas toleram distorções estruturais várias de modo que suas estruturas desviam significativamente da simetria cúbica, passando para simetrias tetragonais a ortorrômbicas (pseudocúbico). Essas características possibilitam a ocupação de inúmeros elementos nos sítios A (e.g. Na, K, Sr, Ba) e B (e.g. Ti, Nb, Zr,Th), tornando a composição de perovskitas naturais extremamente complexas. Estas composições podem ser expressas em termos de componentes moleculares (end member). Em geral, os componentes mais comuns são perovskita $\left(\mathrm{CaTiO}_{3}\right)$, tausonita $\left(\mathrm{Sr}_{2} \mathrm{Ti}_{2} \mathrm{O}_{6}\right)$, loparita $\left(\mathrm{NaCeTi}_{2} \mathrm{O}_{6}\right)$ e lueshita $\left(\mathrm{Na}_{2} \mathrm{Nb}_{2} \mathrm{O}_{6}\right)$.

As perovskitas de Indaiá I são caracterizadas por conteúdos elevados de $\mathrm{Ca}(0,895$ a 0,975 a.f.u.) e de Ti (0,899 a 0,930 a.f.u.), assim preenchendo a maior parte dos sítios A e B, respectivamente. A deficiência de Ca nos sítios A é compensada por elementos terras raras (ETR), com destaque para o Ce (até 0,072 a.f.u.), com importância menor de $\mathrm{Na}(\leq 0,044$ a.f.u.), $\mathrm{Nd}(\leq 0,014$ a.f.u.), La ( $\leq 0,013$ a.f.u.) e Sr (até 0,009 a.f.u.). Nos sítios B, o Ti é compensado principalmente por $\mathrm{Fe}^{3+}$ (até 0,051 a.f.u.) e quantidades menores de $\mathrm{Nb}$ (até 0,018 a.f.u.) e $\mathrm{Zr}(\leq 0,003$ a.f.u.).

Na Figura 28 percebe-se que todas as perovskitas da intrusão Indaiá I situam-se no sistema ternário lueshita-perovskita-loparita, aproximando para a fórmula ideal da perovskita $\left(\mathrm{CaTiO}_{3}\right)$, com este componente representando de 90,99 a 94,29\% em mol da composição do mineral. A predominância desse componente molecular permite classificar o mineral como perovskita. Os demais membros finais que compõem o mineral respondem por teores inferiores a $8,75 \%$ em mol do total, sendo representados principalmente por latrappita $\left(\mathrm{Ca}_{2} \mathrm{NbFeO}_{6}\right)$ e loparita $\left(\mathrm{NaCeTi}_{2} \mathrm{O}_{6}\right)$. Essas características definem o mineral na categoria das perovskitas pobres em ETR. 


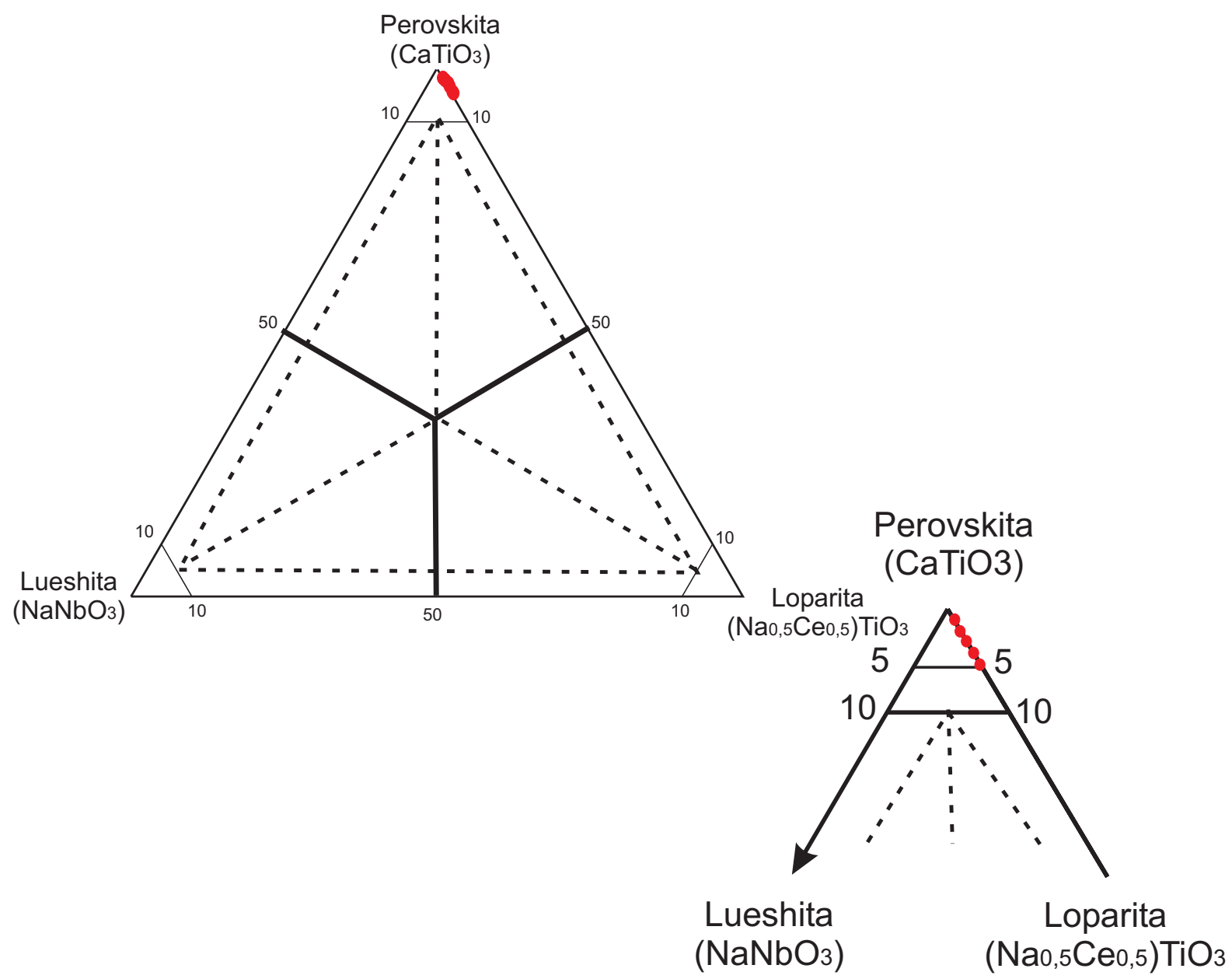

\section{LEGENDA}

- Perovskita da intrusão Indaiá I

Figura 28. Composição de perovskitas da intrusão Indaiá I (\% mol) no sistema perovskita - loparita lueshita. 
Tabela 14 - Composição química de perovskita em cristais que compõe a matriz da rocha da intrusão Indaiá I. Obs: - abaixo do limite de detecção.

\begin{tabular}{|c|c|c|c|c|c|c|c|c|c|c|c|c|c|c|c|c|c|c|c|c|c|c|c|c|c|}
\hline \multirow{2}{*}{$\begin{array}{c}\text { Amostra } \\
\text { Grão }\end{array}$} & \multicolumn{8}{|c|}{$04 \mathrm{a} 2$} & \multicolumn{7}{|c|}{ 04B3 } & \multicolumn{5}{|c|}{$04 \mathrm{~B} 3$} & \multicolumn{5}{|c|}{ 04A1 } \\
\hline & 01 & 02 & 03 & 04 & 05 & 06 & 07 & 08 & 09 & 10 & 11 & 12 & 13 & 14 & 15 & 16 & 17 & 18 & 19 & 20 & 21 & 22 & 23 & 24 & 25 \\
\hline $\mathrm{SiO} 2$ & - & - & - & - & - & 0,02 & - & - & - & - & 0,05 & - & 0,02 & - & - & - & - & - & - & - & - & - & - & - & - \\
\hline $\mathrm{CaO}$ & 35,96 & 38,82 & 36,52 & 35,65 & 36,50 & 38,54 & 38,68 & 37,86 & 38,90 & 36,98 & 39,52 & 38,69 & 37,75 & 36,94 & 38,07 & 36,64 & 35,88 & 36,85 & 36,92 & 38,46 & 37,93 & 38,76 & 39,14 & 39,33 & 35,72 \\
\hline $\mathrm{Na} 2 \mathrm{O}$ & 0,84 & 0,29 & 0,66 & 0,80 & 0,67 & 0,30 & 0,31 & 0,42 & 0,45 & 0,54 & 0,30 & 0,31 & 0,35 & 0,51 & 0,38 & 0,49 & 0,72 & 0,45 & 0,48 & 0,33 & 0,45 & 0,35 & 0,28 & 0,30 & 0,96 \\
\hline $\mathrm{Y} 2 \mathrm{O} 3$ & 0,06 & 0,02 & 0,04 & 0,07 & 0,03 & 0,04 & 0,03 & 0,04 & 0,04 & 0,07 & 0,05 & - & 0,04 & 0,03 & 0,06 & 0,04 & 0,04 & 0,04 & 0,05 & 0,03 & 0,05 & 0,02 & 0,04 & 0,04 & 0,04 \\
\hline $\mathrm{Pr} 2 \mathrm{O} 3$ & 0,52 & 0,23 & 0,42 & 0,50 & 0,39 & 0,29 & 0,30 & 0,31 & 0,25 & 0,43 & 0,15 & 0,32 & 0,35 & 0,42 & 0,29 & 0,39 & 0,48 & 0,36 & 0,38 & 0,25 & 0,36 & 0,28 & 0,21 & 0,24 & 0,56 \\
\hline $\mathrm{La} 2 \mathrm{O} 3$ & 1,11 & 0,89 & 1,38 & 1,52 & 1,26 & 0,90 & 0,95 & 1,05 & 0,91 & 1,19 & 0,64 & 0,99 & 1,03 & 1,15 & 0,98 & 1,16 & 1,53 & 1,18 & 1,10 & 0,90 & 1,10 & 0,97 & 0,89 & 0,85 & 1,43 \\
\hline $\mathrm{Sm} 2 \mathrm{O} 3$ & 0,21 & 0,10 & 0,19 & 0,23 & 0,20 & 0,08 & 0,11 & 0,15 & 0,12 & 0,18 & 0,07 & 0,10 & 0,12 & 0,18 & 0,16 & 0,18 & 0,20 & 0,15 & 0,16 & 0,10 & 0,15 & 0,14 & 0,11 & 0,11 & 0,22 \\
\hline $\mathrm{Nd} 2 \mathrm{O} 3$ & 1,61 & 0,84 & 1,43 & 1,78 & 1,33 & 0,78 & 0,97 & 1,13 & 0,73 & 1,40 & 0,55 & 1,06 & 1,13 & 1,51 & 1,07 & 1,47 & 1,60 & 1,43 & 1,40 & 0,94 & 1,28 & 1,05 & 0,87 & 0,78 & 1,86 \\
\hline HfO2 & 0,05 & 0,02 & - & - & 0,01 & 0,01 & - & - & 0,02 & - & - & - & 0,01 & - & 0,01 & 0,02 & - & 0,01 & - & - & 0,04 & 0,01 & 0,01 & 0,05 & - \\
\hline $\mathrm{TiO} 2$ & 50,66 & 52,40 & 51,96 & 51,11 & 51,86 & 52,59 & 52,07 & 51,96 & 52,38 & 52,49 & 52,47 & 53,04 & 51,77 & 51,59 & 53,41 & 52,23 & 52,07 & 52,42 & 52,24 & 53,47 & 52,33 & 53,26 & 52,69 & 53,24 & 51,13 \\
\hline $\mathrm{FeO}$ & 1,67 & 2,25 & 1,22 & 1,30 & 1,33 & 1,85 & 1,85 & 1,75 & 1,72 & 1,59 & 2,61 & 2,16 & 2,05 & 1,69 & 1,68 & 1,63 & 1,34 & 1,65 & 1,66 & 1,71 & 1,57 & 1,66 & 2,09 & 2,11 & 1,31 \\
\hline $\mathrm{ZrO} 2$ & 0,22 & 0,13 & 0,23 & 0,20 & 0,21 & 0,08 & 0,08 & 0,11 & 0,26 & 0,12 & 0,24 & 0,12 & 0,10 & 0,12 & 0,10 & 0,10 & 0,26 & 0,11 & 0,09 & 0,11 & 0,08 & 0,10 & 0,13 & 0,14 & 0,18 \\
\hline $\mathrm{Nb} 2 \mathrm{O} 5$ & 1,65 & 0,38 & 1,24 & 1,40 & 1,08 & 0,62 & 0,34 & 0,46 & 0,67 & 0,48 & 0,45 & 0,36 & 0,48 & 0,50 & 0,50 & 0,48 & 1,40 & 0,53 & 0,47 & 0,49 & 0,48 & 0,50 & 0,42 & 0,45 & 1,56 \\
\hline $\mathrm{MnO}$ & 0,01 & 0,01 & - & - & 0,03 & 0,01 & 0,01 & 0,01 & 0,02 & 0,01 & - & 0,01 & 0,02 & 0,01 & 0,01 & 0,01 & 0,07 & 0,02 & 0,02 & 0,01 & - & 0,01 & 0,01 & - & - \\
\hline Ta2O5 & 0,12 & 0,05 & 0,05 & 0,02 & 0,04 & 0,05 & 0,03 & 0,08 & 0,02 & 0,10 & 0,06 & 0,05 & 0,03 & 0,07 & 0,05 & 0,06 & 0,04 & 0,08 & 0,06 & 0,04 & 0,03 & 0,06 & 0,06 & 0,05 & 0,09 \\
\hline $\mathrm{ThO} 2$ & 0,25 & 0,10 & 0,07 & 0,05 & 0,03 & 0,04 & 0,11 & 0,21 & - & 0,26 & 0,03 & 0,18 & 0,27 & 0,34 & 0,10 & 0,37 & 0,13 & 0,34 & 0,31 & 0,07 & 0,22 & 0,07 & 0,09 & 0,07 & 0,37 \\
\hline $\mathrm{SrO}$ & 0,42 & 0,56 & 0,35 & 0,45 & 0,38 & 0,57 & 0,51 & 0,46 & 0,41 & 0,45 & 0,70 & 0,51 & 0,52 & 0,47 & 0,49 & 0,46 & 0,45 & 0,46 & 0,45 & 0,48 & 0,43 & 0,49 & 0,55 & 0,51 & 0,41 \\
\hline Total & 99,14 & 99,45 & 99,68 & 99,53 & 98,88 & 98,95 & 98,87 & 98,92 & 98,87 & 99,63 & 99,30 & 100,50 & 98,85 & 98,87 & 100,09 & 99,11 & 100,41 & 99,40 & 98,93 & 99,67 & 99,81 & 100,38 & 99,74 & 100,42 & 100,47 \\
\hline $\mathrm{Fe} 2 \mathrm{O} 3$ & 1,86 & 2,50 & 1,36 & 1,45 & 1,47 & 2,05 & 2,06 & 1,95 & 1,92 & 1,76 & 2,90 & 2,40 & 2,27 & 1,87 & 1,86 & 1,81 & 1,49 & 1,83 & 1,84 & 1,90 & 1,74 & 1,85 & 2,32 & 2,34 & 1,46 \\
\hline $\mathrm{FeO}$ & - & - & - & - & - & - & - & - & - & - & - & - & - & - & - & - & - & - & - & - & - & - & - & - & - \\
\hline
\end{tabular}

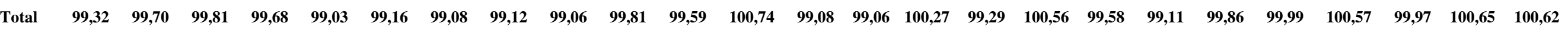


Tabela 14 - Continuação.

\begin{tabular}{|c|c|c|c|c|c|c|c|c|c|c|c|c|c|c|c|c|c|c|c|c|c|c|c|c|c|}
\hline & \multicolumn{25}{|c|}{ Fórmula Estrutural calculada na base de 03 oxigênios } \\
\hline $\mathrm{Si}$ & - & - & - & - & - & 0,001 & - & - & - & - & 0,001 & - & - & - & - & - & - & - & - & - & - & - & - & - & - \\
\hline $\mathrm{Ca}$ & 0,909 & 0,962 & 0,916 & 0,900 & 0,920 & 0,961 & 0,965 & 0,948 & 0,967 & 0,925 & 0,975 & 0,953 & 0,947 & 0,932 & 0,943 & 0,923 & 0,899 & 0,925 & 0,930 & 0,953 & 0,943 & 0,955 & 0,967 & 0,965 & 0,895 \\
\hline $\mathrm{Na}$ & 0,038 & 0,013 & 0,030 & 0,037 & 0,030 & 0,013 & 0,014 & 0,019 & 0,020 & 0,024 & 0,013 & 0,014 & 0,016 & 0,023 & 0,017 & 0,022 & 0,033 & 0,020 & 0,022 & 0,015 & 0,020 & 0,016 & 0,013 & 0,013 & 0,044 \\
\hline $\mathrm{Y}$ & 0,001 & - & 0,001 & 0,001 & - & 0,001 & - & 0,001 & - & 0,001 & 0,001 & - & - & - & 0,001 & - & 0,001 & - & 0,001 & - & 0,001 & - & - & - & 0,001 \\
\hline $\mathrm{La}$ & 0,010 & 0,008 & 0,012 & 0,013 & 0,011 & 0,008 & 0,008 & 0,009 & 0,008 & 0,010 & 0,005 & 0,008 & 0,009 & 0,010 & 0,008 & 0,010 & 0,013 & 0,010 & 0,010 & 0,008 & 0,009 & 0,008 & 0,008 & 0,007 & 0,012 \\
\hline $\mathrm{Ce}$ & 0,062 & 0,038 & 0,064 & 0,072 & 0,058 & 0,035 & 0,041 & 0,048 & 0,032 & 0,054 & 0,023 & 0,042 & 0,046 & 0,055 & 0,044 & 0,055 & 0,068 & 0,055 & 0,052 & 0,037 & 0,054 & 0,042 & 0,034 & 0,034 & 0,075 \\
\hline $\mathrm{Nd}$ & 0,014 & 0,007 & 0,012 & 0,015 & 0,011 & 0,006 & 0,008 & 0,009 & 0,006 & 0,012 & 0,004 & 0,009 & 0,009 & 0,013 & 0,009 & 0,012 & 0,013 & 0,012 & 0,012 & 0,008 & 0,011 & 0,009 & 0,007 & 0,006 & 0,016 \\
\hline $\mathrm{Sm}$ & 0,002 & 0,001 & 0,002 & 0,002 & 0,002 & 0,001 & 0,001 & 0,001 & 0,001 & 0,001 & 0,001 & 0,001 & 0,001 & 0,001 & 0,001 & 0,001 & 0,002 & 0,001 & 0,001 & 0,001 & 0,001 & 0,001 & 0,001 & 0,001 & 0,002 \\
\hline Sitio A & 1,045 & 1,038 & 1,044 & 1,050 & 1,041 & 1,035 & 1,046 & 1,044 & 1,042 & 1,038 & 1,033 & 1,035 & 1,039 & 1,044 & 1,032 & 1,035 & 1,038 & 1,034 & 1,036 & 1,030 & 1,048 & 1,040 & 1,039 & 1,035 & 1,054 \\
\hline $\mathrm{Ti}$ & 0,899 & 0,912 & 0,915 & 0,906 & 0,918 & 0,920 & 0,912 & 0,914 & 0,914 & 0,922 & 0,909 & 0,917 & 0,912 & 0,913 & 0,929 & 0,924 & 0,915 & 0,924 & 0,923 & 0,930 & 0,914 & 0,921 & 0,914 & 0,917 & 0,899 \\
\hline $\mathrm{Nb}$ & 0,018 & 0,004 & 0,013 & 0,015 & 0,012 & 0,007 & 0,004 & 0,005 & 0,007 & 0,005 & 0,005 & 0,004 & 0,005 & 0,005 & 0,005 & 0,005 & 0,015 & 0,006 & 0,005 & 0,005 & 0,005 & 0,005 & 0,004 & 0,005 & 0,016 \\
\hline $\mathrm{Fe} 3+$ & 0,033 & 0,044 & 0,024 & 0,026 & 0,026 & 0,037 & 0,037 & 0,035 & 0,034 & 0,031 & 0,051 & 0,042 & 0,041 & 0,034 & 0,033 & 0,032 & 0,026 & 0,033 & 0,033 & 0,033 & 0,031 & 0,032 & 0,041 & 0,041 & 0,026 \\
\hline $\mathrm{Mn}$ & - & - & - & - & - & - & - & - & - & - & - & - & - & - & - & - & 0,001 & - & - & - & - & - & - & - & - \\
\hline $\mathrm{Ta}$ & 0,001 & - & - & - & - & - & - & 0,001 & - & 0,001 & - & - & - & - & - & - & - & 0,001 & - & - & - & - & - & - & 0,001 \\
\hline $\mathrm{Zr}$ & 0,003 & 0,001 & 0,003 & 0,002 & 0,002 & 0,001 & 0,001 & 0,001 & 0,003 & 0,001 & 0,003 & 0,001 & 0,001 & 0,001 & 0,001 & 0,001 & 0,003 & 0,001 & 0,001 & 0,001 & 0,001 & 0,001 & 0,001 & 0,002 & 0,002 \\
\hline $\mathrm{Hf}$ & - & - & - & - & - & - & - & - & - & - & - & - & - & - & - & - & - & - & - & - & - & - & - & - & - \\
\hline $\mathrm{U}$ & - & - & - & - & - & - & - & - & - & - & - & - & - & - & - & - & - & - & - & - & - & - & - & - & - \\
\hline Sítio B & 0,955 & 0,963 & 0,956 & 0,950 & 0,959 & 0,965 & 0,954 & 0,956 & 0,959 & 0,962 & 0,968 & 0,966 & 0,961 & 0,956 & 0,969 & 0,966 & 0,962 & 0,967 & 0,965 & 0,971 & 0,952 & 0,961 & 0,962 & 0,965 & 0,946 \\
\hline Cátions & 2,000 & 2,001 & 2,000 & 2,000 & 2,000 & 2,001 & 2,001 & 2,001 & 2,001 & 2,000 & 2,001 & 2,001 & 2,001 & 2,001 & 2,000 & 2,000 & 2,000 & 2,000 & 2,000 & 2,000 & 2,000 & 2,000 & 2,001 & 2,001 & 2,000 \\
\hline \multicolumn{26}{|c|}{ Membros finais } \\
\hline Perovskita & 91,00 & 91,88 & 93,28 & 92,12 & 93,00 & 93,47 & 94,06 & 93,34 & 93,31 & 92,22 & 91,53 & 91,48 & 91,90 & 93,02 & 92,25 & 91,29 & 92,42 & 91,25 & 91,87 & 92,82 & 93,72 & 94,29 & 93,46 & 92,91 & 91,62 \\
\hline Latrappita & 3,70 & 4,66 & 2,63 & 2,87 & 2,86 & 3,84 & 3,91 & 3,72 & 3,64 & 3,36 & 5,40 & 4,45 & 4,32 & 3,62 & 3,45 & 3,44 & 2,89 & 3,47 & 3,51 & 3,51 & 3,32 & 3,44 & 4,33 & 4,33 & 2,93 \\
\hline Loparita & 4,24 & 1,35 & 3,24 & 4,05 & 3,30 & 1,42 & 1,49 & 2,03 & 2,14 & 2,61 & 1,41 & 1,45 & 1,68 & 2,51 & 1,79 & 2,35 & 3,59 & 2,17 & 2,30 & 1,54 & 2,18 & 1,66 & 1,34 & 1,38 & 4,93 \\
\hline $\mathrm{La}_{2} \mathrm{Ti}_{2} \mathrm{O}_{7}$ & - & 0,80 & - & - & - & 0,58 & - & - & - & 1,10 & 0,57 & 0,88 & 0,94 & 0,27 & 0,88 & 1,07 & 0,45 & 1,08 & 1,01 & 0,81 & - & 0,02 & 0,37 & 0,75 & - \\
\hline $\mathrm{Ce}_{2} \mathrm{Ti}_{2} \mathrm{O}_{7}$ & - & 0,52 & - & - & - & - & - & - & - & 0,07 & 0,50 & 1,34 & 0,62 & - & 0,95 & 1,18 & - & 1,38 & 0,73 & 0,75 & - & - & - & 0,09 & - \\
\hline $\mathrm{CaZrO}_{3}$ & 0,28 & - & 0,29 & 0,25 & 0,26 & - & 0,10 & 0,13 & 0,32 & - & - & - & - & - & - & - & - & - & - & - & 0,09 & - & - & - & 0,23 \\
\hline $\mathrm{CaThO}_{3}$ & 0,15 & - & 0,04 & 0,03 & 0,02 & - & 0,06 & 0,12 & - & - & - & - & - & - & - & - & - & - & - & - & 0,12 & - & - & - & 0,22 \\
\hline $\mathrm{Sr}_{2} \mathrm{Nb}_{2} \mathrm{O}_{7}$ & 0,64 & 0,42 & 0,52 & 0,68 & 0,57 & 0,68 & 0,38 & 0,51 & 0,59 & 0,54 & 0,49 & 0,40 & 0,54 & 0,58 & 0,54 & 0,54 & 0,66 & 0,59 & 0,53 & 0,54 & 0,54 & 0,55 & 0,47 & 0,49 & - \\
\hline $\mathrm{Sr}_{2} \mathrm{Ta}_{2} \mathrm{O}_{7}$ & - & 0,36 & - & - & - & - & - & 0,15 & - & 0,11 & 0,11 & - & - & - & 0,14 & 0,13 & - & 0,05 & 0,04 & 0,03 & 0,02 & 0,04 & 0,04 & 0,03 & 0,07 \\
\hline
\end{tabular}




\subsection{Intrusão Indaiá II}

\subsubsection{Olivina}

Foram realizadas 20 análises pontuais nos vários tipos texturais da olivina de Indaiá II, sendo 4 em macrocristais, 14 em fenocristais e 2 em xenólitos duníticos. Os resultados obtidos acham-se reunidos na tabela 15 , nas quais constam também as fórmulas estruturais calculadas na base de quatro oxigênios.

Nos macrocristais e fenocristais de olivina, os resultados mostram uma tendência de enriquecimento de $\mathrm{Fe}$ seguida de um conseqüente empobrecimento $\mathrm{Mg}$, do núcleo para a borda dos grãos. São três os seus principais constituintes: $\operatorname{Mg}$ (1,728 a 1,843 a.f.u.), $\operatorname{Si}(0,988$ a 0,999 a.f.u.) e $\mathrm{Fe}^{2+}$ calc $\left(0,185\right.$ a 0,336 a.f.u.); os demais elementos ( $\mathrm{Ti}, \mathrm{Al}, \mathrm{Fe}^{3+}{ }_{\text {calc }}, \mathrm{Ca}, \mathrm{Na}, \mathrm{K}$, $\mathrm{Mn}, \mathrm{Ni}, \mathrm{Cr}$ ), quando presentes, apresentam teores de até totais de 0,050 a.f.u. O histograma das variações moleculares dos macro e fenocristais de olivina (\% mol de Fo, Figura 29) evidenciam a existência de duas variedades de crisólita $\left(\mathrm{Fo}_{83}\right.$ e $\mathrm{Fo}_{86-89}, 06 \%$ e 33\% das análises, respectivamente) e uma variedade de forsterita (Fo90-93, 61\% das análises).

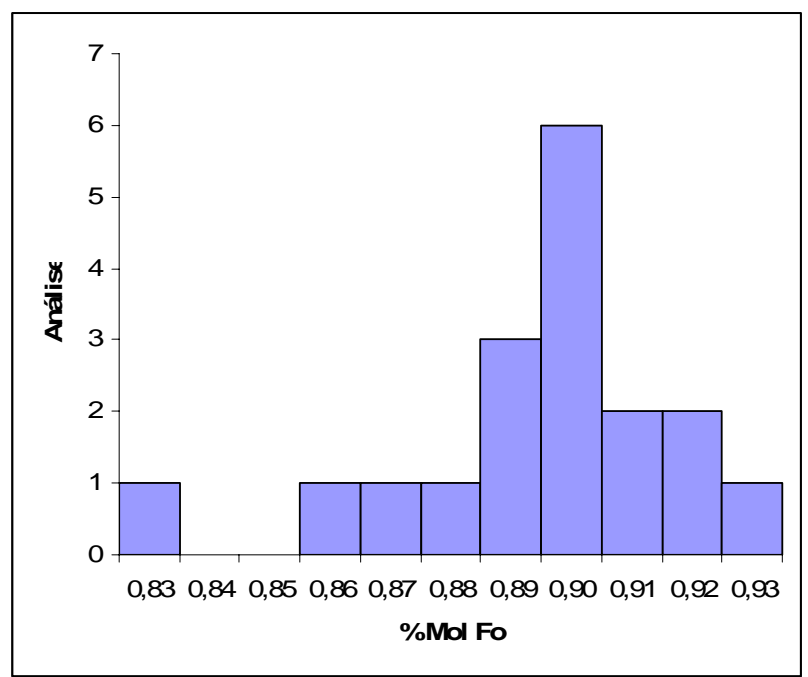

FIGURA 29. Histograma de composição química para os macro e fenocristais de olivina de Indaiá II.

Nos xenólitos duníticos foram analisados apenas os núcleos dos graõs de olivina. Os resultados mostram uma composição química similar aos da rocha hospedeira, com $\mathrm{Mg}$ de 1,760 a 1,820 a.f.u. Representa uma uma crisolita de composição Fo $_{87}$ e Fo 899 , com teores relativamente baixo de $\mathrm{NiO}(0,10$ e $0,13 \%)$, situando-se no limite inferior do intervalo observado para os macro e fenocristais ( $\mathrm{NiO}$ de 0,10 a $0,27 \%$ ). 


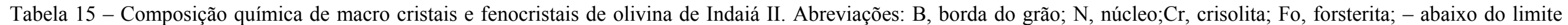
detecção.

\begin{tabular}{|c|c|c|c|c|c|c|c|c|c|c|c|c|c|c|c|c|c|c|c|c|}
\hline \multirow{3}{*}{$\begin{array}{c}\text { Grão } \\
\text { Localização }\end{array}$} & \multicolumn{4}{|c|}{ Macrocristais } & \multicolumn{14}{|c|}{ Fenocristais } & \multicolumn{2}{|c|}{ Xenólito dunítico } \\
\hline & \multicolumn{2}{|c|}{01} & \multicolumn{2}{|c|}{02} & \multicolumn{2}{|c|}{01} & \multicolumn{2}{|c|}{02} & \multicolumn{2}{|c|}{03} & \multicolumn{2}{|c|}{04} & \multicolumn{2}{|c|}{05} & \multicolumn{2}{|c|}{06} & \multicolumn{2}{|c|}{07} & \multirow{2}{*}{$\begin{array}{l}01 \\
\mathrm{~N} \\
\end{array}$} & \multirow{2}{*}{$\begin{array}{l}02 \\
\mathrm{~N}\end{array}$} \\
\hline & $\mathrm{B}$ & $\mathrm{N}$ & $\mathrm{B}$ & $\mathrm{N}$ & $\mathrm{B}$ & $\mathrm{N}$ & $\mathrm{B}$ & $\mathrm{N}$ & $\mathrm{B}$ & $\mathrm{N}$ & $\mathrm{B}$ & $\mathrm{N}$ & $\mathrm{B}$ & $\mathrm{N}$ & $\mathrm{B}$ & $\mathrm{N}$ & $\mathrm{B}$ & $\mathrm{N}$ & & \\
\hline $\mathrm{SiO}_{2}$ & 39,26 & 39,38 & 40,73 & 40,44 & 39,80 & 39,97 & 41,22 & 40,38 & 40,17 & 40,05 & 39,38 & 39,75 & 40,37 & 40,14 & 40,19 & 40,07 & 39,76 & 40,07 & 40,05 & 39,38 \\
\hline $\mathrm{TiO}_{2}$ & 0,01 & 0,04 & - & - & 0,12 & 0,06 & 0,04 & - & 0,02 & 0,05 & - & - & - & 0,03 & 0,04 & 0,01 & 0,02 & 0,11 & 0,05 & - \\
\hline $\mathrm{Al}_{2} \mathrm{O}_{3}$ & 0,01 & - & - & 0,02 & - & 0,03 & - & 0,01 & - & 0,05 & 0,05 & 0,06 & 0,03 & 0,02 & 0,03 & 0,01 & - & - & 0,05 & 0,05 \\
\hline $\mathrm{FeO}$ & 17,05 & 13,75 & 10,17 & 9,73 & 10,78 & 11,40 & 8,20 & 8,34 & 10,13 & 9,94 & 11,91 & 11,52 & 10,32 & 11,15 & 10,34 & 9,04 & 12,60 & 11,28 & 9,94 & 11,91 \\
\hline $\mathrm{MnO}$ & 0,26 & 0,21 & 0,14 & 0,16 & 0,11 & 0,12 & 0,11 & 0,08 & 0,19 & 0,18 & 0,31 & 0,12 & 0,15 & 0,14 & 0,18 & 0,08 & 0,23 & 0,14 & 0,18 & 0,31 \\
\hline $\mathrm{MgO}$ & 43,83 & 45,05 & 48,85 & 49,21 & 48,25 & 47,69 & 50,67 & 50,91 & 48,21 & 48,38 & 47,77 & 47,60 & 48,39 & 47,94 & 49,15 & 49,74 & 46,27 & 47,40 & 48,38 & 47,77 \\
\hline $\mathrm{CaO}$ & 0,05 & 0,06 & 0,02 & 0,01 & 0,15 & 0,13 & - & 0,01 & 0,51 & 0,35 & 0,39 & 0,09 & 0,20 & 0,14 & 0,26 & 0,02 & 0,05 & 0,13 & 0,35 & 0,39 \\
\hline $\mathrm{Na}_{2} \mathrm{O}$ & - & 0,02 & - & 0,01 & 0,02 & 0,01 & - & 0,01 & 0,02 & 0,02 & 0,02 & 0,02 & 0,01 & 0,01 & 0,01 & - & 0,01 & 0,01 & 0,02 & 0,02 \\
\hline $\mathrm{Cr}_{2} \mathrm{O}_{3}$ & 0,01 & - & 0,01 & 0,01 & 0,08 & 0,08 & 0,01 & - & 0,03 & 0,04 & - & 0,07 & 0,05 & 0,06 & 0,02 & 0,08 & 0,01 & 0,02 & 0,04 & - \\
\hline $\mathrm{NiO}$ & 0,11 & 0,13 & 0,22 & 0,20 & 0,20 & 0,26 & 0,21 & 0,24 & 0,09 & 0,10 & 0,13 & 0,24 & 0,15 & 0,27 & 0,18 & 0,27 & 0,19 & 0,26 & 0,10 & 0,13 \\
\hline Total & 100,60 & 98,63 & 100,14 & 99,78 & 99,52 & 99,76 & 100,46 & 99,99 & 99,39 & 99,17 & 99,96 & 99,49 & 99,65 & 99,93 & 100,40 & 99,32 & 99,15 & 99,42 & 99,17 & 99,96 \\
\hline $\mathrm{FeO}$ & 15,92 & 13,60 & 10,04 & 9,00 & 9,64 & 10,66 & 8,10 & 6,44 & 9,57 & 9,83 & 9,28 & 10,35 & 9,96 & 10,46 & 8,70 & 7,69 & 12,33 & 11,11 & 9,42 & 9,51 \\
\hline $\mathrm{Fe}_{2} \mathrm{O}_{3}$ & 1,25 & 0,17 & 0,14 & 0,81 & 1,27 & 0,82 & 0,11 & 2,12 & 0,62 & 1,74 & 0,80 & 1,30 & 0,40 & 0,77 & 1,81 & 1,51 & 0,30 & 0,19 & 0,58 & 2,66 \\
\hline \multirow[t]{2}{*}{ Total } & 100,72 & 98,65 & 100,15 & 99,86 & 99,65 & 99,84 & 100,47 & 100,20 & 99,45 & 100,31 & 99,65 & 99,62 & 99,69 & 100,01 & 100,58 & 99,47 & 99,18 & 99,44 & 99,23 & 100,22 \\
\hline & \multicolumn{20}{|c|}{ Fórmula Estrutural calculada na base de 4 oxigênios } \\
\hline $\mathrm{Si}$ & 0,988 & 0,998 & 0,999 & 0,992 & 0,984 & 0,990 & 0,998 & 0,981 & 0,993 & 0,981 & 0,990 & 0,987 & 0,995 & 0,991 & 0,982 & 0,984 & 0,997 & 0,996 & 0,991 & 0,974 \\
\hline $\mathrm{Ti}$ & - & -1 & - & - & 0,002 & 0,001 & 0,001 & - & - & 0,001 & 0,003 & - & - & 0,001 & 0,001 & - & - & 0,002 & 0,001 & - \\
\hline $\mathrm{Al}$ & 0,001 & - & - & 0,001 & - & 0,001 & - & - & - & 0,001 & - & 0,003 & 0,001 & 0,001 & 0,001 & - & - & - & 0,001 & 0,001 \\
\hline $\mathrm{Fe} 3+$ & 0,024 & 0,003 & 0,003 & 0,015 & 0,024 & 0,015 & 0,002 & 0,039 & 0,012 & 0,032 & 0,015 & 0,024 & 0,007 & 0,014 & 0,033 & 0,028 & 0,006 & 0,004 & 0,011 & 0,050 \\
\hline $\mathrm{Fe} 2+$ & 0,336 & 0,288 & 0,206 & 0,185 & 0,200 & 0,221 & 0,164 & 0,131 & 0,198 & 0,203 & 0,192 & 0,215 & 0,206 & 0,216 & 0,179 & 0,158 & 0,259 & 0,231 & 0,195 & 0,198 \\
\hline $\mathrm{Mn}$ & 0,004 & 0,003 & 0,002 & 0,002 & 0,002 & 0,003 & 0,002 & 0,002 & 0,004 & 0,004 & 0,003 & 0,003 & 0,003 & 0,003 & 0,004 & 0,002 & 0,005 & 0,003 & 0,004 & 0,007 \\
\hline $\mathrm{Mg}$ & 1,643 & 1,701 & 1,785 & 1,800 & 1,779 & 1,760 & 1,829 & 1,843 & 1,777 & 1,768 & 1,788 & 1,761 & 1,779 & 1,764 & 1,790 & 1,821 & 1,728 & 1,756 & 1,785 & 1,760 \\
\hline $\mathrm{Ca}$ & 0,001 & 0,002 & - & - & 0,004 & 0,003 & - & - & 0,014 & 0,004 & 0,008 & 0,002 & 0,005 & 0,004 & 0,007 & - & 0,001 & 0,003 & 0,009 & 0,010 \\
\hline $\mathrm{Ni}$ & 0,002 & 0,003 & 0,004 & 0,004 & 0,004 & 0,005 & 0,004 & 0,005 & 0,002 & 0,005 & 0,002 & 0,005 & 0,003 & 0,005 & 0,004 & 0,005 & 0,004 & 0,005 & 0,002 & 0,003 \\
\hline Cations & 2,999 & 2,999 & 2,999 & 2,999 & 3,001 & 3,000 & 3,000 & 3,001 & 3,000 & 3,001 & 3,000 & 3,001 & 3,000 & 3,000 & 3,001 & 3,001 & 3,000 & 3,000 & 3,000 & 3,002 \\
\hline \multirow[t]{2}{*}{$\mathrm{Mg} /\left(\mathrm{Mg}+\mathrm{Fe}^{2+}\right)$} & 0,83 & 0,86 & 0,90 & 0,91 & 0,90 & 0,89 & 0,92 & 0,93 & 0,90 & 0,90 & 0,90 & 0,89 & 0,90 & 0,89 & 0,91 & 0,92 & 0,87 & 0,88 & 0,90 & 0,90 \\
\hline & \multicolumn{20}{|c|}{ Nomenclatura (Deer, et al. 1992) } \\
\hline
\end{tabular}




\subsubsection{Piroxênios}

Foram realizadas 27 análises pontuais nos vários tipos texturais de piroxênios de Indaiá II, sendo 16 em microfenocristais (diâmetros entre 5 e 8,5 mm, com determinações nos núcleo e borda dos grãos), 7 em cristais da matriz e 04 em cristais de xenólitos duníticos. Os resultados obtidos são encontrados na tabela 16 e 17, nas quais constam também as fórmulas estruturais calculadas na base de seis oxigênios e as porcentagens dos componentes moleculares.

No diagrama de classificação para piroxênios (Morimoto, 1990), Figura 30A observa-se que os piroxênios da intrusão II concentram-se no grupo do quadrilatério (QUAD), apresentando variação composicional bastante restrita e rica em $\mathrm{Ca}$ e $\mathrm{Mg}$, correspondendo a composição de um diopsídio, apresentando porcentagem média dos membros finais $\mathrm{En}_{39,73} \mathrm{Fs}_{10,23} \mathrm{Wo}_{47,97}$ e com fórmula média representada por $\left(\mathrm{Fe}^{3+}{ }_{0,07} \mathrm{Ti}_{0,01} \mathrm{Mg}_{0,80} \mathrm{Fe}^{2+}{ }_{0,10} \mathrm{Mn}_{0,01} \mathrm{Ca}_{0,95} \mathrm{Na}_{0,05}\right)_{2,00}\left(\mathrm{Si}_{1,95} \mathrm{Al}_{0,03} \mathrm{Fe}^{3+}{ }_{0,02}\right)_{2,00}$.

Os sítios tetraédricos desses piroxênios são preenchidos em grande parte por $\mathrm{Si}$ e pequena contribuição de $\mathrm{Al}$ (máximo 0,059 a.f.u.), com a parte restante completada com $\mathrm{Fe}^{3+}$ (máximo de 0,046 a.f.u.). O sítio M1 é ocupado preferencialmente por $\mathrm{Mg}(0,698$ a 0,865 a.f.u.) quantidades reduzidas de $\mathrm{Ti}, \mathrm{Fe}, \mathrm{Cr}$ e $\mathrm{Ca}$. O sítio M2 é ocupado por $\mathrm{Ca}(0,856$ a 0,986 a.f.u.) e $\mathrm{Na}(\leq 0,135$ a.f.u.).

Como particularidade dos microfenocristais (Tabela 16), ressalta-se o seu caráter zonado, com enriquecimento em $\mathrm{Fe}$ e empobrecimento em $\mathrm{Mg}$ do núcleo para a borda dos grãos. 
Tabela 16 - Composição química de microfenocristais de piroxênios de Indaiá II. Abreviações: B, borda do grão; N, núcleo; - abaixo do limite detecção.

Grão 02 03 05 07 08

\begin{tabular}{ccccccccccccccccc} 
Localização & $\mathrm{B}$ & $\mathrm{N}$ & $\mathrm{B}$ & $\mathrm{N}$ & $\mathrm{B}$ & $\mathrm{N}$ & $\mathrm{B}$ & $\mathrm{N}$ & $\mathrm{B}$ & $\mathrm{N}$ & $\mathrm{B}$ & $\mathrm{N}$ & $\mathrm{B}$ & $\mathrm{N}$ & $\mathrm{B}$ & $\mathrm{N}$ \\
\hline $\mathrm{SiO}_{2}$ & 51,85 & 52,15 & 52,07 & 52,47 & 52,02 & 52,50 & 52,45 & 51,99 & 52,31 & 52,06 & 52,57 & 52,09 & 52,46 & 52,52 & 52,31 & 52,06 \\
$\mathrm{TiO}_{2}$ & 0,09 & 0,11 & 0,03 & 0,20 & 0,01 & - & 0,12 & 0,13 & 0,10 & 0,20 & 0,11 & 0,12 & 0,06 & - & 0,10 & 0,20 \\
$\mathrm{Al}_{2} \mathrm{O}_{3}$ & 1,34 & 1,19 & 1,01 & 1,46 & 0,98 & 0,73 & 1,06 & 1,08 & 0,96 & 1,32 & 0,88 & 1,26 & 0,88 & 0,87 & 0,96 & 1,32 \\
$\mathrm{FeO}$ & 6,31 & 6,19 & 6,98 & 6,30 & 6,82 & 5,96 & 6,79 & 6,73 & 6,49 & 6,31 & 6,07 & 6,35 & 6,61 & 6,79 & 6,95 & 6,31 \\
$\mathrm{MnO}$ & 0,32 & 0,35 & 0,40 & 0,37 & 0,34 & 0,27 & 0,36 & 0,40 & 0,38 & 0,40 & 0,35 & 0,41 & 0,32 & 0,36 & 0,38 & 0,40 \\
$\mathrm{MgO}$ & 13,99 & 13,88 & 14,28 & 13,95 & 13,99 & 14,76 & 14,13 & 14,03 & 14,23 & 14,11 & 14,50 & 14,04 & 14,23 & 13,86 & 14,23 & 14,11 \\
$\mathrm{CaO}$ & 24,65 & 24,65 & 24,60 & 24,68 & 24,60 & 24,71 & 24,41 & 24,56 & 24,48 & 24,34 & 24,59 & 24,55 & 24,81 & 24,53 & 24,48 & 24,34 \\
$\mathrm{Na} \mathrm{O}_{2}$ & 0,28 & 0,30 & 0,27 & 0,28 & 0,28 & 0,22 & 0,24 & 0,25 & 0,29 & 0,26 & 0,28 & 0,26 & 0,23 & 0,25 & 0,29 & 0,26 \\
$\mathrm{~K}_{2} \mathrm{O}$ & 0,01 & 0,03 & - & 0,02 & 0,01 & - & - & - & - & - & - & - & - & - & - & - \\
$\mathrm{Cr}_{2} \mathrm{O}_{3}$ & - & - & 0,01 & 0,07 & 0,03 & - & 0,03 & 0,01 & - & 0,05 & - & - & - & 0,01 & - & 0,54 \\
$\mathrm{NiO}$ & - & - & 0,02 & 0,02 & 0,01 & 0,02 & 0,01 & 0,01 & 0,01 & - & 0,20 & - & 0,03 & - & 0,01 & - \\
$\mathrm{Total}$ & 98,85 & 98,85 & 99,67 & 99,82 & 99,09 & 99,16 & 99,60 & 99,20 & 99,25 & 99,04 & 99,56 & 99,07 & 99,64 & 99,21 & 99,71 & 99,53 \\
$\mathrm{FeO}$ & 3,91 & 4,33 & 3,68 & 4,70 & 4,10 & 3,55 & 4,89 & 4,25 & 4,17 & 4,50 & 4,04 & 4,33 & 4,24 & 5,14 & 4,17 & 4,50 \\
$\mathrm{Fe}_{2} \mathrm{O}_{3}$ & 2,67 & 2,06 & 3,67 & 1,78 & 3,01 & 2,67 & 2,11 & 2,76 & 2,59 & 2,01 & 2,26 & 2,24 & 2,64 & 1,84 & 3,09 & 2,01 \\
$\mathrm{~T}$ & 99,11 & 99,05 & $\mathbf{1 0 0 , 0 1}$ & 99,91 & 99,35 & 99,40 & 99,77 & 99,46 & 99,50 & 99,19 & 99,54 & 99,30 & 99,87 & 99,38 & 100,01 & 99,19
\end{tabular}

$\begin{array}{lllllllllllllllll}\text { Total } & 99,11 & 99,05 & 100,01 & 99,91 & 99,35 & 99,40 & 99,77 & 99,46 & 99,50 & 99,19 & 99,54 & 99,30 & 99,87 & 99,38 & 100,01 & 99,19\end{array}$

$\begin{array}{llllllllllllllll}1,941 & 1,953 & 1,935 & 1,947 & 1,946 & 1,954 & 1,952 & 1,942 & 1,950 & 1,945 & 1,956 & 1,947 & 1,950 & 1,964 & 1,943 & 1,939\end{array}$ $\begin{array}{lllllllllllllllll}0,059 & 0,047 & 0,044 & 0,053 & 0,043 & 0,032 & 0,047 & 0,048 & 0,042 & 0,055 & 0,039 & 0,053 & 0,039 & 0,036 & 0,042 & 0,058\end{array}$ $\begin{array}{lllllllllllllllllll}- & - & 0,021 & - & 0,011 & 0,014 & 0,001 & 0,010 & 0,008 & - & 0,006 & - & 0,011 & - & 0,015 & 0,004\end{array}$ $\begin{array}{llllllllllllllll}2,000 & 2,000 & 2,000 & 2,000 & 2,000 & 2,000 & 2,000 & 2,000 & 2,000 & 2,000 & 2,000 & 2,000 & 2,000 & 2,000 & 2,000 & 2,000\end{array}$ $\begin{array}{llllllllllllllllll}- & 0,005 & - & 0,011 & - & - & - & - & 0,004 & - & 0,002 & - & 0,002\end{array}$

$\begin{array}{llllllllllllllll}0,075 & 0,058 & 0,082 & 0,050 & 0,074 & 0,061 & 0,058 & 0,068 & 0,065 & 0,057 & 0,058 & 0,063 & 0,063 & 0,052 & 0,072 & 0,053\end{array}$ $\begin{array}{llllllllllllllllll}0,003 & 0,003 & 0,001 & 0,006 & - & - & 0,003 & 0,004 & 0,003 & 0,006 & 0,003 & 0,003 & 0,002 & - & 0,003 & 0,006\end{array}$

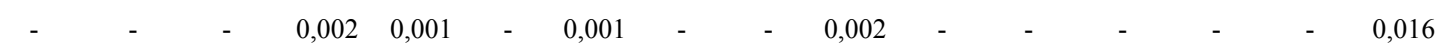
$\begin{array}{llllllllllllllll}0,781 & 0,775 & 0,791 & 0,772 & 0,780 & 0,819 & 0,784 & 0,781 & 0,791 & 0,786 & 0,804 & 0,782 & 0,789 & 0,773 & 0,788 & 0,784\end{array}$ $\begin{array}{lllllllllllllllll}0,123 & 0,136 & 0,115 & 0,146 & 0,129 & 0,111 & 0,153 & 0,134 & 0,131 & 0,141 & 0,126 & 0,136 & 0,133 & 0,161 & 0,131 & 0,141\end{array}$ $\begin{array}{lllllllllllllllll}0,010 & 0,011 & 0,010 & 0,012 & 0,011 & 0,008 & 0,001 & 0,013 & 0,010 & 0,005 & 0,008 & 0,013 & 0,010 & 0,011 & 0,006 & 0,001\end{array}$ $\begin{array}{rrrrr}0,001 & 0,001 \quad-\quad 0,001 & 0,001\end{array}$ $0,007 \quad 0,009 \quad-\quad 0,001 \quad 0,005$

$\begin{array}{llllllllllllllll}1,000 & 1,000 & 1,000 & 1,000 & 1,000 & 1,000 & 1,000 & 1,000 & 1,000 & 1,000 & 1,000 & 1,000 & 1,000 & 1,000 & 1,000 & 1,000\end{array}$ 
Tabela 16 - Continuação

\begin{tabular}{|c|c|c|c|c|c|c|c|c|c|c|c|c|c|c|c|c|c|}
\hline \multirow{11}{*}{ M2 } & $\mathrm{Mn}$ & - & - & 0,003 & - & - & 0,0 & 010 & 0,00 & $002 \quad 0,00$ & 0,003 & - & & - & - & 0,006 & 0,012 \\
\hline & $\mathrm{K}$ & - & - & - & - & - & - & - & - & $-\quad-$ & - & - & & - & - & - & - \\
\hline & $\mathrm{Ca}$ & 0,981 & 0,979 & 0,980 & 0,981 & 0,981 & $\begin{array}{ll}0,986 & 0,9\end{array}$ & $973 \quad 0,98$ & $983 \quad 0,978$ & $978 \quad 0,97$ & 0,978 & 0,98 & & 984 & $0,983 \quad 0$, & 0,975 & 0,971 \\
\hline & $\mathrm{Na}$ & 0,020 & 0,022 & 0,019 & 0,020 & 0,020 & $0,016 \quad 0,0$ & $017 \quad 0,01$ & $018 \quad 0,02$ & $021 \quad 0,01$ & 0,020 & 0,01 & & 017 & $0,018 \quad 0$ & 0,021 & 0,018 \\
\hline & $\Sigma M 2$ & 1,001 & 1,001 & 1,002 & 1,001 & 1,002 & $1,001 \quad 1,0$ & $001 \quad 1,06$ & $001 \quad 1,00$ & $001 \quad 1,00$ & 1,001 & 1,00 & & 001 & $1,001 \quad 1$, & 1,002 & 1,001 \\
\hline & Cátions & 4,001 & 4,001 & 4,002 & 4,001 & 4,002 & $4,001 \quad 4,0$ & $001 \quad 4,00$ & 0014,001 & $001 \quad 4,00$ & 4,001 & 4,00 & & 001 & 4,001 & 4,002 & 4,001 \\
\hline & \multicolumn{17}{|c|}{ Componentes Moleculares (\%) } \\
\hline & Enstatita & 39,07 & & $, 91 \quad 39,14$ & 38,95 & 38, & $, 77 \quad 40,64$ & 39,23 & 38,93 & 39,44 & 9,514 & 0,15 & 39,18 & 39,23 & $\begin{array}{l}38,67 \\
\end{array}$ & $7 \quad 39,16$ & 39,51 \\
\hline & Ferrosilita & 10,45 & & $, 34 \quad 11,44$ & $10,5 \mathrm{C}$ & 11, & ,21 $\quad 9,68$ & 11,19 & 11,18 & 10,75 & 0,59 & 0,04 & 10,64 & 10,79 & $\begin{array}{ll}9 & 11,24\end{array}$ & $\begin{array}{l}4 \\
41,39\end{array}$ & 10,59 \\
\hline & Wollastonita & 49,46 & & ,66 48,46 & 49,5 & 49 , & $, 01 \quad 48,90$ & 48,71 & 48,98 & 48,75 & 8,964 & 18,82 & 49,25 & 49,15 & $5 \quad 49,17$ & 788,40 & 48,96 \\
\hline & $\mathrm{g} /\left(\mathrm{Mg} / \mathrm{Fe}^{2+}\right)$ & 0,86 & 0,8 & 0,87 & 0,84 & 4 & 0,88 & 0,84 & 0,85 & 0,86 & 0,85 & 0,86 & 0,85 & 0,86 & 0,83 & 0,86 & 0,85 \\
\hline
\end{tabular}


Tabela 17 - Composição química de cristais de piroxênios da matriz das rochas de Indaiá II e de seus xenólitos duníticos. Abreviações: N, núcleo;- abaixo do limite detecção; ${ }^{*}+$ Mn.

\begin{tabular}{|c|c|c|c|c|c|c|c|c|c|c|c|}
\hline & & \multicolumn{6}{|c|}{ Matriz } & \multicolumn{4}{|c|}{ Xenólito dunítico } \\
\hline Grão & 01 & 02 & 03 & 04 & 05 & 06 & 07 & 01 & 02 & 03 & 04 \\
\hline Localização & $\mathrm{N}$ & $\mathrm{N}$ & $\mathrm{N}$ & $\mathrm{N}$ & $\mathrm{N}$ & $\mathrm{N}$ & $\mathrm{N}$ & $\mathrm{N}$ & $\mathrm{N}$ & $\mathrm{N}$ & $\mathrm{N}$ \\
\hline $\mathrm{SiO}_{2}$ & 53,28 & 52,74 & 53,28 & 53,44 & 53,46 & 52,07 & 53,04 & 51,68 & 52,45 & 52,25 & 52,48 \\
\hline $\mathrm{TiO}_{2}$ & 1,71 & 1,42 & 0,96 & 0,68 & 0,90 & 0,51 & 0,69 & 0,06 & 0,09 & 0,07 & 0,05 \\
\hline $\mathrm{Al}_{2} \mathrm{O}_{3}$ & 0,19 & 0,38 & 0,27 & 0,23 & 0,31 & 0,41 & 0,35 & 1,26 & 1,04 & 0,95 & 0,98 \\
\hline $\mathrm{FeO}$ & 5,14 & 4,52 & 4,39 & 4,33 & 4,45 & 8,70 & 9,66 & 6,40 & 5,96 & 6,00 & 6,32 \\
\hline $\mathrm{MnO}$ & 0,06 & 0,03 & 0,07 & 0,12 & 0,11 & 0,03 & 0,02 & - & - & - & 0,04 \\
\hline $\mathrm{MgO}$ & 0,12 & 0,12 & 0,09 & 0,13 & 0,11 & 0,24 & 0,22 & 0,40 & 0,32 & 0,34 & 0,41 \\
\hline $\mathrm{CaO}$ & 15,30 & 14,98 & 15,85 & 15,52 & 15,80 & 12,96 & 12,71 & 14,33 & 14,18 & 14,40 & 14,39 \\
\hline $\mathrm{Na}_{2} \mathrm{O}$ & 23,32 & 23,68 & 23,99 & 23,90 & 23,93 & 22,37 & 21,58 & 24,62 & 24,31 & 24,45 & 24,39 \\
\hline $\mathrm{K}_{2} \mathrm{O}$ & 1,27 & 1,07 & 0,96 & 0,94 & 0,99 & 1,63 & 1,88 & 0,27 & 0,29 & 0,22 & 0,29 \\
\hline $\mathrm{Cr}_{2} \mathrm{O}_{3}$ & 0,05 & 0,08 & 0,01 & 0,02 & 0,06 & 0,05 & 0,04 & 0,02 & 0,02 & 0,01 & 0,02 \\
\hline Total & 100,42 & 99,01 & 99,87 & 99,31 & 100,11 & 98,95 & 100,17 & 99,04 & 98,66 & 98,70 & 99,37 \\
\hline $\mathrm{FeO}$ & 1,98 & 2,02 & 1,03 & 1,70 & 1,09 & 3,10 & 4,76 & 3,08 & 4,64 & 4,15 & 4,10 \\
\hline $\mathrm{Fe}_{2} \mathrm{O}_{3}$ & 3,51 & 2,78 & 3,73 & 2,93 & 3,73 & 6,21 & 5,44 & 3,69 & 1,47 & 2,05 & 2,47 \\
\hline Total & 100,77 & 99,28 & 100,24 & 99,60 & 100,48 & 99,58 & 100,71 & 99,40 & 98,81 & 98,91 & 99,61 \\
\hline
\end{tabular}

Fórmula Estrutural calculada na base de 06 oxigênios

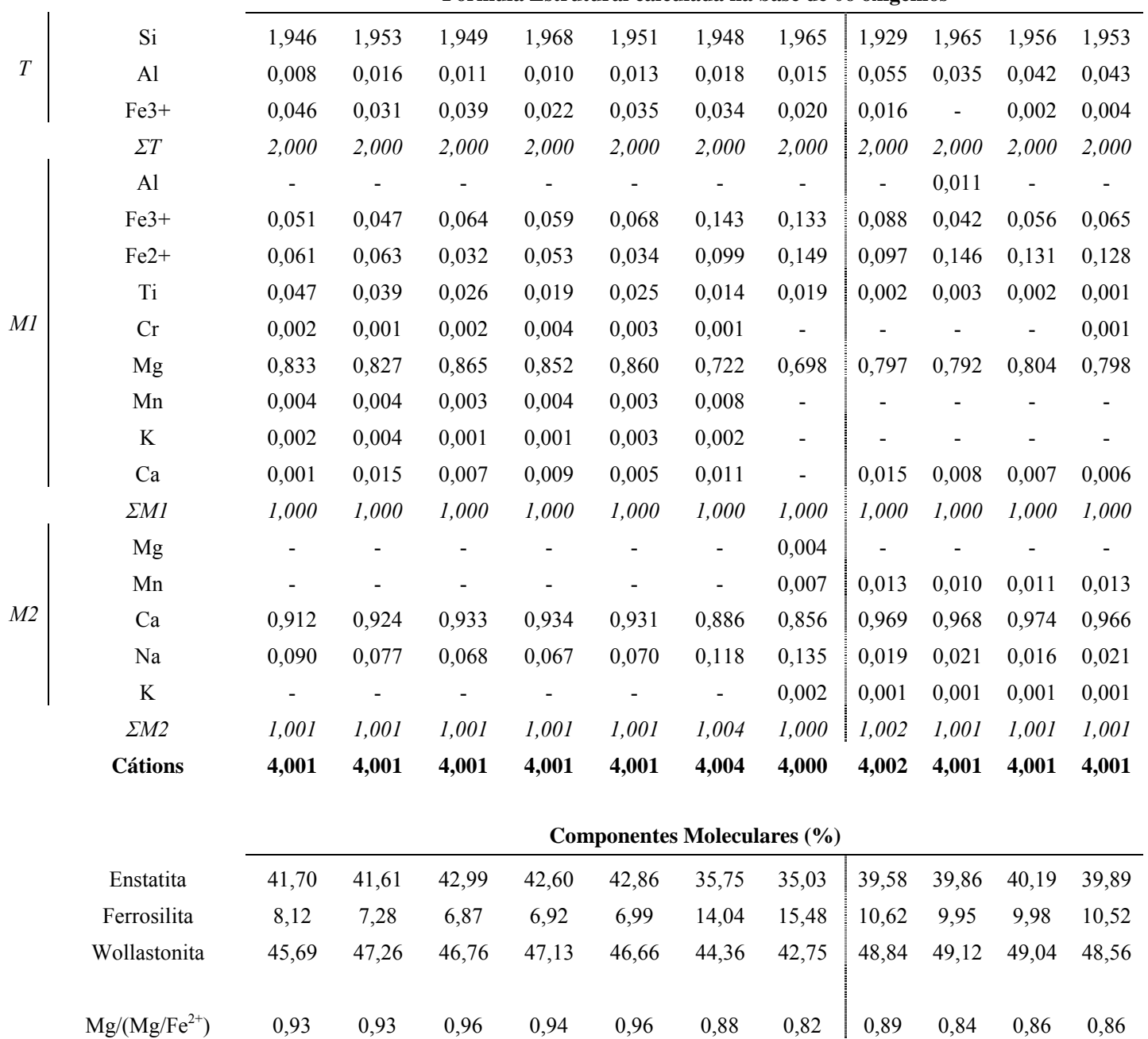



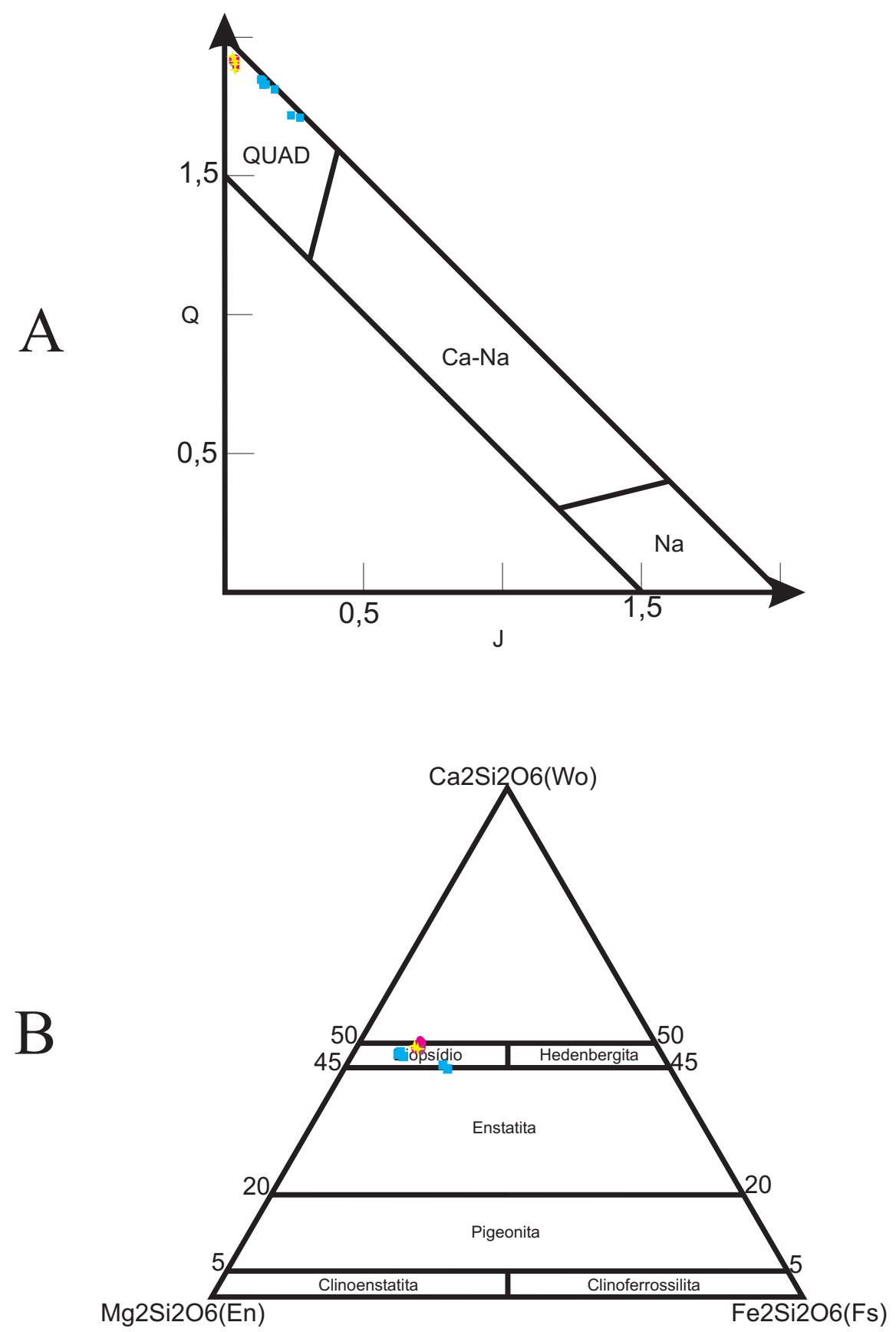

\section{LEGENDA}

macrocristais borda

macrocristais núcleo

cristais da matriz

xenólito dunítico

Figura 30. A: Diagrama de classificação de piroxênios segundo Morimoto (1990), onde $\mathrm{Q}=\mathrm{Ca}+\mathrm{Mg}+\mathrm{Fe} 2 \mathrm{e}$ $\mathrm{J}=2 \mathrm{Na}$; B: Diagrama ternário de classificação de clinopiroxênios (En - Fs - Wo), onde En $=100 \mathrm{Mg} /(\mathrm{Ca}+\mathrm{Mg}$ $+\mathrm{Fe} 2+\mathrm{Fe} 3+\mathrm{Mn}+\mathrm{Na}), \mathrm{Fs}=100(\mathrm{Fe} 2+\mathrm{Fe} 3+\mathrm{Mn}) /(\mathrm{Ca}+\mathrm{Mg}+\mathrm{Fe} 2+\mathrm{Fe} 3+\mathrm{Mn}+\mathrm{Na}) \mathrm{e} \mathrm{Wo}=100 \mathrm{Ca} /(\mathrm{Ca}+$ $\mathrm{Mg}+\mathrm{Fe} 2+\mathrm{Fe} 3+\mathrm{Mn}+\mathrm{Na})$. 


\subsubsection{Ilmenita}

Foram realizadas 03 análises em grãos de minerais opacos registrados na matriz das rochas e em xenólitos duníticos. Os resultados das determinações estão reunidas na Tabela 18, com as fórmulas estruturais e porcentagens dos componentes moleculares.

Tabela 18 - Composição química de ilmenitas presentes na matriz das rochas de Indaiá II e nos xenólitos duníticos. Abreviações: N, núcleo; -, abaixo do limite detecção

\begin{tabular}{|c|c|c|c|}
\hline & \multicolumn{2}{|c|}{ Matriz } & Xenólito dunítico \\
\hline Grão & 01 & 02 & 01 \\
\hline Localização & $\mathrm{N}$ & $\mathrm{N}$ & $\mathrm{N}$ \\
\hline $\mathrm{SiO}_{2}$ & 0,01 & - & 0,01 \\
\hline $\mathrm{TiO}_{2}$ & 50,35 & 51,59 & 49,75 \\
\hline $\mathrm{Al}_{2} \mathrm{O}_{3}$ & 0,08 & 0,05 & 0,07 \\
\hline $\mathrm{Cr}_{2} \mathrm{O}_{3}$ & 1,57 & 0,81 & 1,72 \\
\hline $\mathrm{FeO}$ & 31,16 & 30,46 & 30,85 \\
\hline $\mathrm{MnO}$ & 0,62 & 0,66 & 0,75 \\
\hline $\mathrm{MgO}$ & 13,17 & 13,03 & 13,47 \\
\hline $\mathrm{CaO}$ & 0,16 & 0,50 & 0,16 \\
\hline $\mathrm{Nb}_{2} \mathrm{O}_{5}$ & 0,11 & 0,16 & 0,18 \\
\hline Total & 97,21 & 97,26 & 96,97 \\
\hline $\mathrm{FeO}$ & 20,16 & 21,40 & 18,88 \\
\hline $\mathrm{Fe}_{2} \mathrm{O}_{3}$ & 12,21 & 10,06 & 13,29 \\
\hline \multirow[t]{2}{*}{ Total } & 98,42 & 98,26 & 98,29 \\
\hline & \multicolumn{3}{|c|}{ Fórmula Estrutural calculada na base de 06 oxigênios } \\
\hline $\mathrm{Si}$ & - & - & 0,001 \\
\hline $\mathrm{Ti}$ & 1,765 & 1,811 & 1,744 \\
\hline $\mathrm{Al}$ & 0,004 & 0,003 & 0,004 \\
\hline $\mathrm{Cr}$ & 0,058 & 0,030 & 0,063 \\
\hline $\mathrm{Fe}^{2+}$ & 0,786 & 0,835 & 0,736 \\
\hline $\mathrm{Fe}^{3+}$ & 0,436 & 0,360 & 0,475 \\
\hline $\mathrm{Mn}$ & 0,024 & 0,026 & 0,030 \\
\hline $\mathrm{Mg}$ & 0,915 & 0,907 & 0,936 \\
\hline $\mathrm{Ca}$ & 0,008 & 0,025 & 0,008 \\
\hline $\mathrm{Nb}$ & 0,002 & 0,003 & 0,004 \\
\hline \multirow[t]{2}{*}{ Cátions } & 4,000 & 4,000 & 4,000 \\
\hline & \multicolumn{3}{|c|}{ Componentes Moleculares (\%) } \\
\hline $\mathrm{Al}_{2} \mathrm{O}_{3}$ & 0,10 & 0,07 & 0,09 \\
\hline $\mathrm{Cr}_{2} \mathrm{O}_{3}$ & 1,32 & 0,70 & 1,43 \\
\hline $\mathrm{Nb}_{2} \mathrm{O}_{5}$ & 0,05 & 0,08 & 0,09 \\
\hline Hematita & 18,06 & 14,78 & 19,54 \\
\hline Pirofanita & 1,11 & 1,22 & 1,34 \\
\hline Geikielita & 41,70 & 42,25 & 42,30 \\
\hline Ilmenita & 37,66 & 40,92 & 35,21 \\
\hline
\end{tabular}


Nos diagramas envolvendo os componentes FeTiO3, Fe2O3, MgTiO3 e MnTiO3, que representam respectivamente os principais membros finais ilmenita, hematita, geikielita e pirofanita (Figura 31), indicam uma composição bastante restrita e representada principalmente pelas moléculas de ilmenita(35,21 a 40,92\% mol) e geikielita $(41,70$ a 42,30\% mol), com quantidades menores de hematita (14,78 a 19,54\% mol). São ilmenitas (Ti, 1,744 a 1,811 e Fe, 1,195 a 1,222 a.f.u.) caracterizadas por elevado teor de $\operatorname{Mg}(0,907$ a 0,936 a.f.u.), pequenas quantidades de $\mathrm{Cr}(0,030$ a 0,063 a.f.u.) e traço de $\mathrm{Nb}(0,002$ a 0,004 a.f.u.).

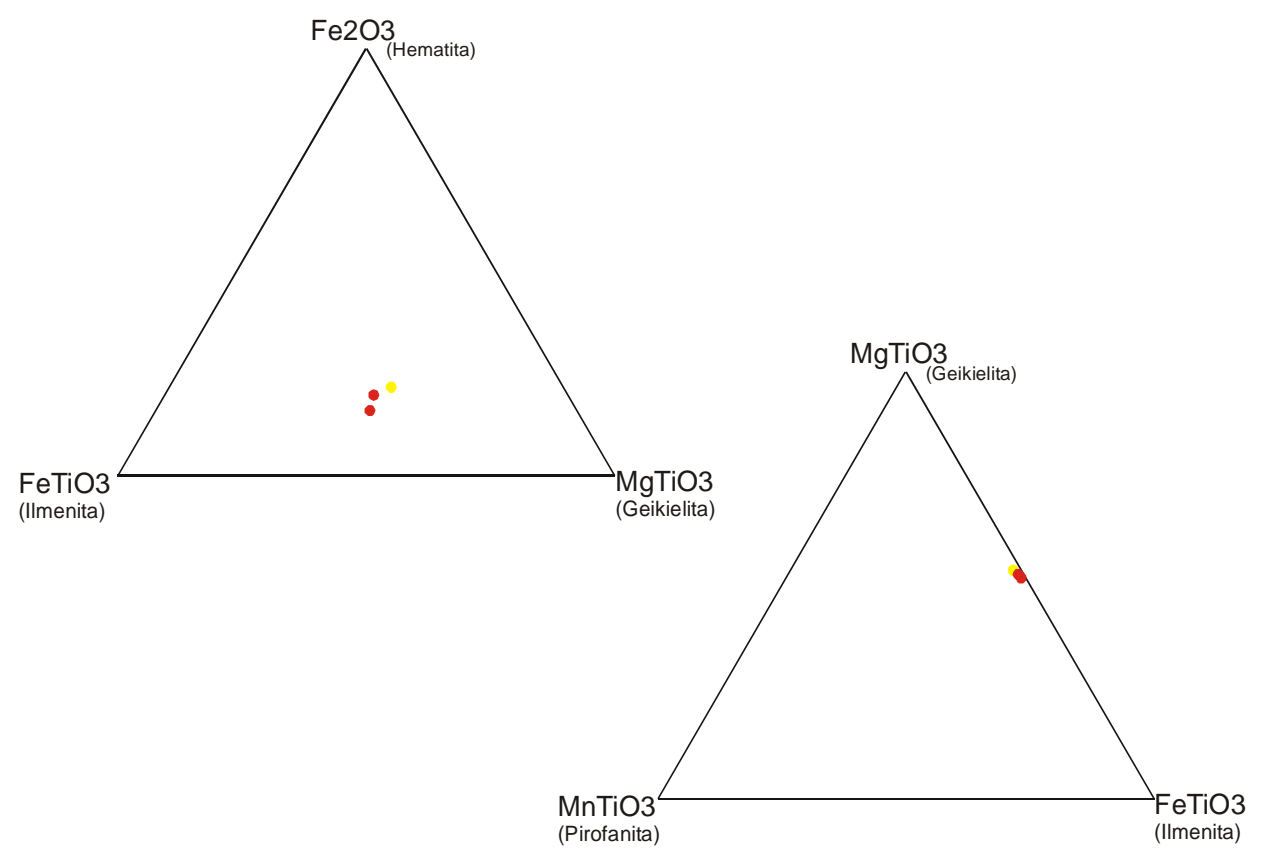

\section{LEGENDA}

\section{- Cristais da matriz}

\section{Cristais de xenólito dunítico}

Figura 31 - Composição de ilmenitas (mol\% em peso) de Indaiá II em diagrama triangular Fe2O3 - MgTiO3 - FeTiO3. No lado direito, o diagrama apresenta os campos de variação das ilmenitas analisadas para os cristais da matriz e xenólito dunítico. 


\subsubsection{Grupo dos espinélios}

As 9 análises químicas de espinélio encontrado na forma de grãos isolados na matriz ou como inclusões na olivina de rochas de Indaiá II estão dispostas na Tabela 19. As análises foram executadas somente no centro dos grãos devido ao tamanho reduzido dos mesmos.

Tabela 19 - Composição química de minerais do grupo dos espinélios das rochas de Indaiá II e nos xenólitos duníticos. Abreviações: N, núcleo; -, abaixo do limite detecção.

\begin{tabular}{|c|c|c|c|c|c|c|c|c|c|}
\hline \multirow[b]{2}{*}{ Amostra } & \multicolumn{7}{|c|}{ Magnetita } & \multicolumn{2}{|c|}{ Cromita } \\
\hline & 01 & 02 & 03 & 04 & 05 & 06 & Inclusão em olivina & 01 & 02 \\
\hline Grão/Localização & $\mathrm{N}$ & $\mathrm{N}$ & $\mathrm{N}$ & $\mathrm{N}$ & $\mathrm{N}$ & $\mathrm{N}$ & & $\mathrm{N}$ & $\mathrm{N}$ \\
\hline $\mathrm{SiO}_{2}$ & - & 0,10 & 0,04 & 0,09 & 0,08 & 0,04 & 0,03 & 0,03 & 0,15 \\
\hline $\mathrm{TiO}_{2}$ & 10,29 & 13,50 & 12,79 & 16,08 & 6,82 & 13,85 & 11,70 & 6,27 & 5,53 \\
\hline $\mathrm{Al}_{2} \mathrm{O}_{3}$ & 0,25 & 0,14 & 0,21 & 1,19 & 0,52 & 0,16 & 0,19 & 3,17 & 0,66 \\
\hline $\mathrm{Cr}_{2} \mathrm{O}_{3}$ & 11,34 & 0,91 & 4,16 & 1,18 & 23,15 & 2,12 & 6,19 & 29,02 & 31,90 \\
\hline $\mathrm{FeO}$ & 69,30 & 75,32 & 74,18 & 59,62 & 60,83 & 76,32 & 71,86 & 53,07 & 52,78 \\
\hline $\mathrm{MnO}$ & 0,95 & 0,88 & 0,98 & 1,35 & 0,90 & 0,97 & 0,85 & 0,91 & 0,97 \\
\hline $\mathrm{MgO}$ & 4,38 & 4,28 & 4,17 & 16,19 & 4,69 & 4,05 & 4,19 & 5,76 & 4,80 \\
\hline $\mathrm{CaO}$ & 0,12 & 0,14 & 0,05 & 0,41 & 0,07 & 0,01 & 0,04 & 0,04 & 0,12 \\
\hline $\mathrm{Nb}_{2} \mathrm{O}_{5}$ & 0,01 & 0,04 & - & 0,04 & - & 0,04 & - & - & 0,04 \\
\hline Total & 96,63 & 95,31 & 96,59 & 96,14 & 97,06 & 97,56 & 95,05 & 98,28 & 96,94 \\
\hline $\mathrm{FeO}$ & 33,87 & 36,72 & 36,58 & 20,46 & 30,45 & 38,10 & 35,18 & 28,86 & 28,81 \\
\hline $\mathrm{Fe}_{2} \mathrm{O}_{3}$ & 39,36 & 42,89 & 41,79 & 43,50 & 33,75 & 42,46 & 40,75 & 26,91 & 26,64 \\
\hline \multirow[t]{2}{*}{ Total } & 100,56 & 99,60 & 100,77 & 100,49 & 100,43 & 101,80 & 99,13 & 100,97 & 99,60 \\
\hline & \multicolumn{9}{|c|}{ Fórmula Estrutural calculada na base de 32 oxigênios } \\
\hline $\mathrm{Si}$ & 0,001 & 0,029 & 0,010 & 0,024 & 0,022 & 0,011 & 0,010 & 0,008 & 0,043 \\
\hline $\mathrm{Ti}$ & 2,239 & 2,969 & 2,783 & 3,199 & 1,478 & 2,990 & 2,586 & 1,322 & 1,204 \\
\hline $\mathrm{A} 12$ & 0,086 & 0,049 & 0,072 & 0,371 & 0,177 & 0,055 & 0,065 & 1,048 & 0,223 \\
\hline $\mathrm{Cr}$ & 2,593 & 0,211 & 0,953 & 0,246 & 5,273 & 0,481 & 1,439 & 6,434 & 7,298 \\
\hline $\mathrm{Fe}^{2+}$ & 8,194 & 8,984 & 8,852 & 4,527 & 7,336 & 9,144 & 8,649 & 6,766 & 6,971 \\
\hline $\mathrm{Fe}^{3+}$ & 8,732 & 9,623 & 9,274 & 8,826 & 7,458 & 9,344 & 9,189 & 5,786 & 5,911 \\
\hline Mn & 0,232 & 0,217 & 0,241 & 0,302 & 0,219 & 0,235 & 0,213 & 0,216 & 0,238 \\
\hline Mg & 1,887 & 1,868 & 1,799 & 6,383 & 2,015 & 1,732 & 1,836 & 2,408 & 2,069 \\
\hline $\mathrm{Ca}$ & 0,036 & 0,045 & 0,016 & 0,116 & 0,022 & 0,002 & 0,013 & 0,013 & 0,038 \\
\hline $\mathrm{Nb}$ & 0,001 & 0,005 & - & 0,005 & - & 0,005 & - & - & 0,005 \\
\hline \multirow[t]{2}{*}{ Cátions } & 24,000 & 24,000 & 24,000 & 24,000 & 24,000 & 24,000 & 24,000 & 24,000 & 24,000 \\
\hline & \multicolumn{9}{|c|}{ Membros finais } \\
\hline Espinélio & 0,55 & 0,33 & 0,47 & 2,92 & 1,30 & 0,37 & 0,43 & 7,19 & 1,53 \\
\hline Hercinita & - & - & - & - & - & - & - & - & - \\
\hline Magnetita & 56,11 & 64,42 & 61,06 & 69,50 & 54,99 & 61,85 & 60,03 & 39,66 & 40,39 \\
\hline Mg-cromita & 16,66 & 1,42 & 6,27 & 1,94 & 6,08 & 3,19 & 9,40 & - & - \\
\hline Mn-cromita & - & - & - & - & - & - & - & - & - \\
\hline Cromita & - & - & - & - & 26,72 & - & - & 44,10 & 49,86 \\
\hline Ulvospinélio & 24,59 & 27,93 & 27,75 & 0,90 & - & 29,60 & 26,49 & - & - \\
\hline Mg-ulvospinélio & 2,09 & 5,91 & 4,45 & 24,40 & 10,90 & 4,99 & 3,65 & 9,06 & 8,22 \\
\hline Mn-ulvospinélio & - & - & - & 0,34 & - & - & - & - & - \\
\hline
\end{tabular}


$\mathrm{O}$ grupo dos espinélios pode ser representado pela fórmula geral $\mathrm{R}_{8}{ }^{2+} \mathrm{R}_{16}{ }^{3+} \mathrm{O}_{32}$ (Deer et al., 1992), sendo $\mathrm{R}^{2+}$ os elementos $\mathrm{Fe}^{2+}, \mathrm{Mn}, \mathrm{Mg}, \mathrm{Ca}, \mathrm{Zn}, \mathrm{Nb}$ e Ni, enquanto $\mathrm{R}^{3+}$ inclui Ti, $\mathrm{Al}$, $\mathrm{Si}, \mathrm{Cr}$ e $\mathrm{Fe}^{3+}$. Essa composição pode ser traduzida através de uma solução sólida dada pela combinação de vários componentes moleculares, alguns sendo freqüentes nos espinélios de rochas de afinidade kimberlítica, como por exemplo magnesiocromita $\left(\mathrm{MgCr}_{2} \mathrm{O}_{4}\right)$, ulvoespinélio $\left(\mathrm{Fe}_{2} \mathrm{TiO}_{4}\right)$, magnetita $\left(\mathrm{Fe}_{3} \mathrm{O}_{4}\right)$, cromita $\left(\mathrm{FeCr}_{2} \mathrm{O}_{4}\right)$, espinélio $\left(\mathrm{MgAl}_{2} \mathrm{O}_{4}\right)$ e outros.

Os espinélios de Indaiá II analisados apresentam ampla variação composicional, com teores relativamente elevados de $\mathrm{FeO}_{\text {total }}\left(52,78\right.$ a 76,32\%), $\mathrm{Cr}_{2} \mathrm{O}_{3}\left(0,91\right.$ a 31,90\%) e $\mathrm{TiO}_{2}$ $\left(10,29\right.$ a $16,08 \%$ e 5,53 a $6,82 \%$, em grãos respectivamente de baixo e alto $\left.\mathrm{Cr}_{2} \mathrm{O}_{3}\right)$, apreciáveis de $\mathrm{MgO}$ (4,05 a 5,76\%, exceto uma análise com 16,19\%) e $\mathrm{MnO}(0,85$ a 1,35\%), e muito baixo de $\mathrm{Al}_{2} \mathrm{O}_{3}(<0,7 \%$, exceto um ponto com 3,17\%). Essa variabilidade química demonstrada, expressa a composição complexa desses espinélios, caracterizada pela participação maior dos componentes magnetita e ulvöspinélio, variável embora às vezes alta de magnesioulvöespinélio, magnesiocromita e cromita e desprezível de espinélio (Al).

Os resultandos obtidos (Tabela 19) indicam que os minerais do grupo dos espinélios analisados são representados pelos seguintes membros, considerando a fórmula estrutural média $\mathrm{XY}_{2} \mathrm{O}_{32}$ e a porcentagem média dos principais membros finais:

- Magnetita: $\quad\left(\mathrm{Mg}_{2,50} \mathrm{Fe}^{2+}{ }_{7,96} \mathrm{Mn}_{0,24} \mathrm{Ca}_{0,04}\right) \quad\left(\mathrm{Si}_{0,02} \mathrm{Al}_{0,13} \mathrm{Cr}_{1,60} \mathrm{Fe}^{3+}{ }_{8,92} \mathrm{Ti}_{2,61}\right)_{2,00} \quad \mathrm{O}_{32} \quad$ ou $\mathrm{Es}_{0,9} \mathrm{Mag}_{88,9} \mathrm{Cr}_{10,2}$;

- Cromita: $\left(\mathrm{Mg}_{2,24} \mathrm{Fe}^{2+}{ }_{6,87} \mathrm{Mn}_{0,23} \mathrm{Ca}_{0,03}\right) \quad\left(\mathrm{Si}_{0,03} \mathrm{Al}_{0,64} \mathrm{Cr}_{6,87} \mathrm{Fe}^{3+}{ }_{5,85} \mathrm{Ti}_{1,26}\right)_{2,00} \quad \mathrm{O}_{32} \quad$ ou $\mathrm{Es}_{4,4} \mathrm{Mag}_{40,0} \mathrm{Cr}_{47,0}$.

No diagrama ternário $\mathrm{Cr}-\mathrm{Al}-\left(\mathrm{Fe}^{2+}+2 \mathrm{Ti}\right)$, Figura 32, observa-se a distribuição dos cristais de magnetita e cromitas a intrusão II, onde se percebe variação máxima do membro Al - espinélio em torno de $7 \%$.

\subsubsection{Kalsilita}

Mineral do grupo da nefelina, a kalsilita foi caracterizada com auxílio de microssonda eletrônica (WDS), em decorrência do estudo de xenólitos microcristalinos e nefelíticos encontrados em rochas da intrusão Indaiá II. Ressalta-se que nenhum feldspatóide foi registrado na rocha hospedeira. Ocorre tão somente na assembléia mineral destes xenólitos na forma de diminutos cristais incolores a levemente amarelados. 


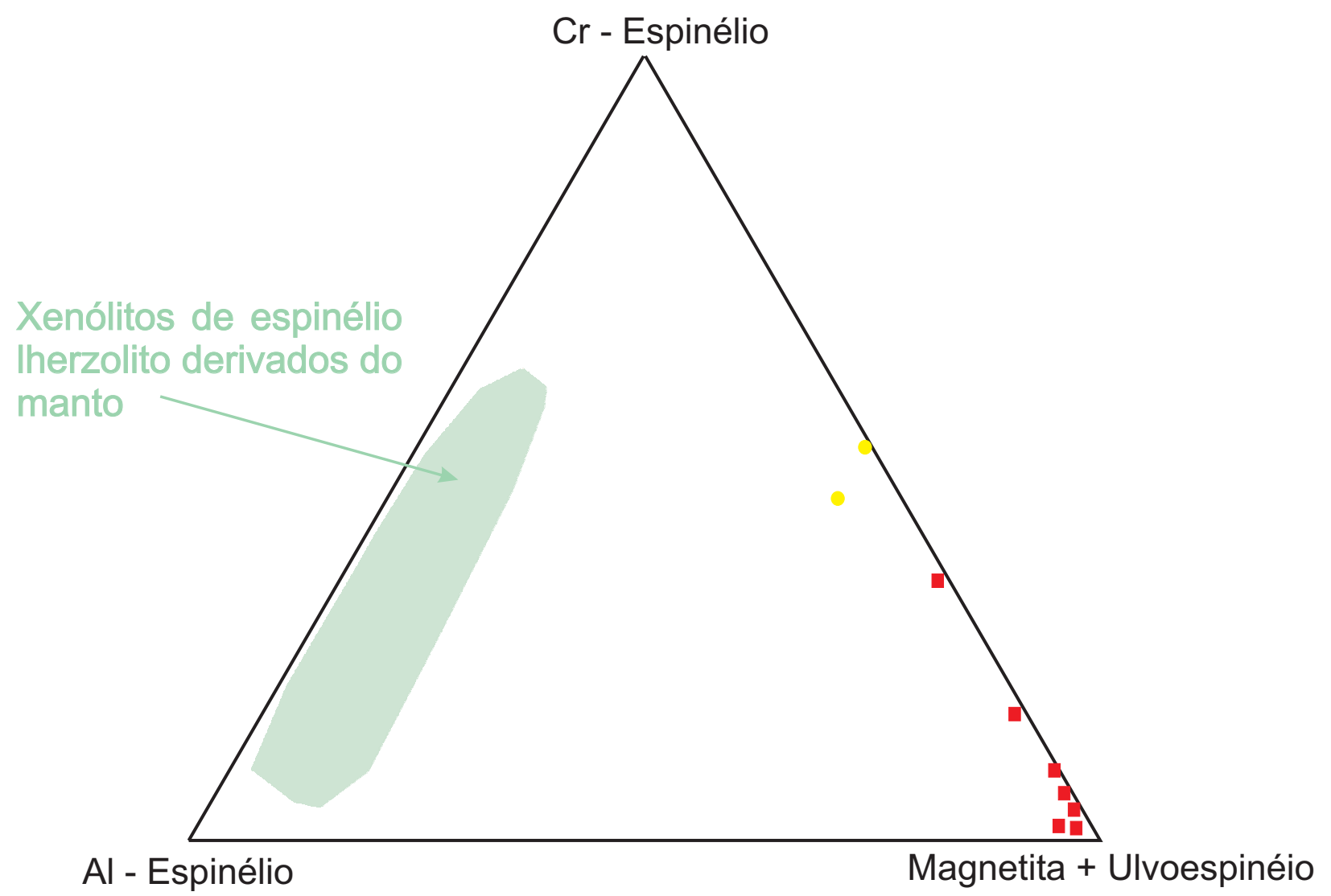

\section{LEGENDA}

Cristais de magnetita

Cristais de cromita

Figura 32. Diagrama Cr - Al - (Fe2++2Ti) para espinélios da intrusão IndaiálI. Modificado de Melluso et al., 2007. 
As determinações relativas às 10 análises pontuais de kalsilita são fornecidas na Tabela 20, com sua fórmula estrutural e porcentagem dos componentes moleculares nefelina-kalsilitaquartzo (Ne-Ks-Qz).

Os resultados apontam para o comportamento homogêneo do mineral, com $\mathrm{Na}_{2} \mathrm{O}$ entre 2,07 e $3,58 \%$ (em peso) e $\mathrm{K}_{2} \mathrm{O}$ entre 24,20 e 25,85\%. As concentrações de $\mathrm{Fe}_{2} \mathrm{O}_{3}(3,95$ a $5,55 \%)$ se mantêm elevadas, enquanto as de $\operatorname{MgO}(0,25$ a 0,58\%) são relativamente baixas. Essas características, aliadas aos conteúdos em sílica e alumina da Tabela 22, correspondem a uma kalsilita de composição $\mathrm{Ne}_{11,13-20,64} \mathrm{Ks}_{72,87-79,36} \mathrm{Q}_{0-2,82}$.

Tabela 20 - Composição química de mineral do grupo da nefelina presentes em xenólitos microcristalino da intrusão das rochas de Indaiá II. Abreviações: $\mathrm{N}$, núcleo do grão; $\sum \mathrm{R}=(\mathrm{Na}+\mathrm{K}+2 \mathrm{Ca}) ;-$, abaixo do limite de detecção.

\begin{tabular}{|c|c|c|c|c|c|c|c|c|c|c|}
\hline Grão & 01 & 02 & 03 & 04 & 05 & 06 & 07 & 08 & 09 & 10 \\
\hline Localização & $\mathrm{N}$ & $\mathrm{N}$ & $\mathrm{N}$ & $\mathrm{N}$ & $\mathrm{N}$ & $\mathrm{N}$ & $\mathrm{N}$ & $\mathrm{N}$ & $\mathrm{N}$ & $\mathrm{N}$ \\
\hline $\mathrm{SiO}_{2}$ & 38,64 & 38,63 & 38,51 & 38,14 & 38,55 & 38,47 & 38,67 & 38,30 & 38,44 & 38,24 \\
\hline $\mathrm{TiO}_{2}$ & 0,01 & 0,09 & 0,03 & 0,01 & 0,03 & 0,07 & 0,09 & - & 0,02 & - \\
\hline $\mathrm{Al}_{2} \mathrm{O}_{3}$ & 27,54 & 27,58 & 27,79 & 27,63 & 27,68 & 28,12 & 27,25 & 27,89 & 27,48 & 28,14 \\
\hline $\mathrm{Fe}_{2} \mathrm{O}_{3}$ & 3,95 & 4,49 & 4,84 & 4,86 & 5,07 & 4,91 & 4,39 & 4,46 & 5,55 & 4,89 \\
\hline $\mathrm{MnO}$ & - & 0,03 & 0,03 & 0,04 & - & - & 0,01 & - & - & 0,01 \\
\hline $\mathrm{MgO}$ & 0,53 & 0,58 & 0,28 & 0,28 & 0,27 & 0,35 & 0,31 & 0,31 & 0,26 & 0,25 \\
\hline $\mathrm{CaO}$ & 0,01 & - & - & - & - & - & - & - & - & - \\
\hline $\mathrm{Na}_{2} \mathrm{O}$ & 2,94 & 2,41 & 3,50 & 3,58 & 3,05 & 3,10 & 3,37 & 3,43 & 3,35 & 3,58 \\
\hline $\mathrm{K}_{2} \mathrm{O}$ & 24,88 & 25,85 & 24,86 & 24,67 & 24,73 & 24,72 & 24,20 & 24,43 & 24,78 & 24,24 \\
\hline Total & 98,50 & 99,65 & 99,83 & 99,22 & 99,38 & 99,73 & 98,28 & 98,82 & 99,87 & 99,34 \\
\hline \multicolumn{11}{|c|}{ Fórmula Estrutural calculada na base de 32 oxigênios } \\
\hline $\mathrm{Si}$ & 8,258 & 8,197 & 8,117 & 8,085 & 8,197 & 10,160 & 8,141 & 8,284 & 8,149 & 8,129 \\
\hline $\mathrm{Ti}$ & 0,002 & 0,014 & 0,005 & 0,002 & 0,005 & 0,024 & 0,011 & 0,014 & - & 0,003 \\
\hline $\mathrm{Al}$ & 6,935 & 6,896 & 6,903 & 6,902 & 6,935 & 6,677 & 7,014 & 6,880 & 6,993 & 6,849 \\
\hline $\mathrm{Fe}^{3+}$ & 0,635 & 0,717 & 0,768 & 0,776 & 0,811 & 1,295 & 0,782 & 0,708 & 0,714 & 0,883 \\
\hline $\mathrm{Mg}$ & - & 0,006 & 0,004 & 0,007 & 0,001 & 0,025 & - & 0,001 & - & - \\
\hline $\mathrm{Mg}$ & 0,169 & 0,183 & 0,086 & 0,089 & 0,085 & 0,989 & 0,109 & 0,097 & 0,097 & 0,081 \\
\hline $\mathrm{Ca}$ & 0,003 & - & - & - & - & 0,329 & - & - & - & - \\
\hline $\mathrm{Na}$ & 1,217 & 0,990 & 1,432 & 1,470 & 1,258 & 0,929 & 1,270 & 1,400 & 1,416 & 1,372 \\
\hline $\mathrm{K}$ & 6,782 & 6,998 & 6,685 & 6,671 & 6,708 & 3,573 & 6,673 & 6,615 & 6,630 & 6,683 \\
\hline Cátions & 24,00 & 24,00 & 24,00 & 24,00 & 24,00 & 24,00 & 24,00 & 24,00 & 24,00 & 24,00 \\
\hline$\Sigma \mathrm{R}$ & 8,00 & 7,99 & 8,12 & 8,14 & 7,97 & 5,16 & 7,94 & 8,01 & 8,05 & 8,05 \\
\hline $\mathrm{Ne}$ & 13,82 & 11,13 & 15,74 & 16,06 & 14,24 & 20,64 & 14,45 & 15,82 & 15,91 & 15,11 \\
\hline Ks & 77,01 & 78,67 & 73,49 & 72,87 & 75,93 & 79,36 & 75,94 & 74,74 & 74,46 & 73,63 \\
\hline Q & 2,29 & 2,55 & 2,69 & 2,77 & 2,46 & 0,00 & 2,40 & 2,36 & 2,41 & 2,82 \\
\hline
\end{tabular}




\subsubsection{Perovskita}

Foram realizadas 25 análises quantitativas em cristais de perovskitas de Indaiá II, tendo como referência apenas os centros dos grãos, face ao seu tamanho reduzido. As determinações químicas encontram-se na Tabela 21, juntamente com a fórmula estrutural e a porcentagem dos componentes moleculares.

Os resultados demonstram que as perovskitas de Indaiá II são caracterizadas por conteúdos elevados de $\mathrm{Ca}(0,938$ a 0,967 a.f.u.) e de Ti (0,905 a 0,923 a.f.u.). Considerando a fórmula estrutural geral desse mineral como sendo $\mathrm{ABO}_{3}$ (Deer et al. 1992), os sítios A e $\mathrm{B}$ são em grande parte ocupados, respectivamente, por aqueles dois elementos. Em todas as análises, a pequena deficiência nos sítios A é compensada principalmente pelos elementos terras raras (ETR), em particular o Ce (0,033 a 0,056 a.f.u.), com teores menores de $\mathrm{Na}(\leq$ 0,021 a.f.u.), $\mathrm{Sr}$ e $\mathrm{Nd}(\leq 0,012$ a.f.u.). Estes resultados permitem enquadrar tais minerais na categoria das perovskitas pobres em ETR. Já nos sítios B, o Ti é compensado por $\mathrm{Fe}^{3+}(\leq$ 0,044 a.f.u.) e quantidades menores de $\mathrm{Nb}$ e $\mathrm{Th}(\leq 0,010$ a.f.u.).

Na Figura 33 observa-se que todas as análises da perovskita de Indaiá II acham-se locadas no sistema ternário lueshita-perovskita-loparita, concentrando-se junto ao extremo do componente molecular perovskita $\left(\mathrm{CaTiO}_{3}\right)$, que constitui de 90,66 a 94,20\% em mol da composição do mineral. Isto posto, o mineral é classificado pelo próprio homônimo do membro final, perovskita. Outros componentes que compõem o mineral representam concentrações inferiores a $10 \% \mathrm{em}$ mol do total, sendo representados principalmente por latrappita $\left(\mathrm{Ca}_{2} \mathrm{NbFeO}_{6}\right)$ e loparita $\left(\mathrm{NaCeTi}_{2} \mathrm{O}_{6}\right)$. 

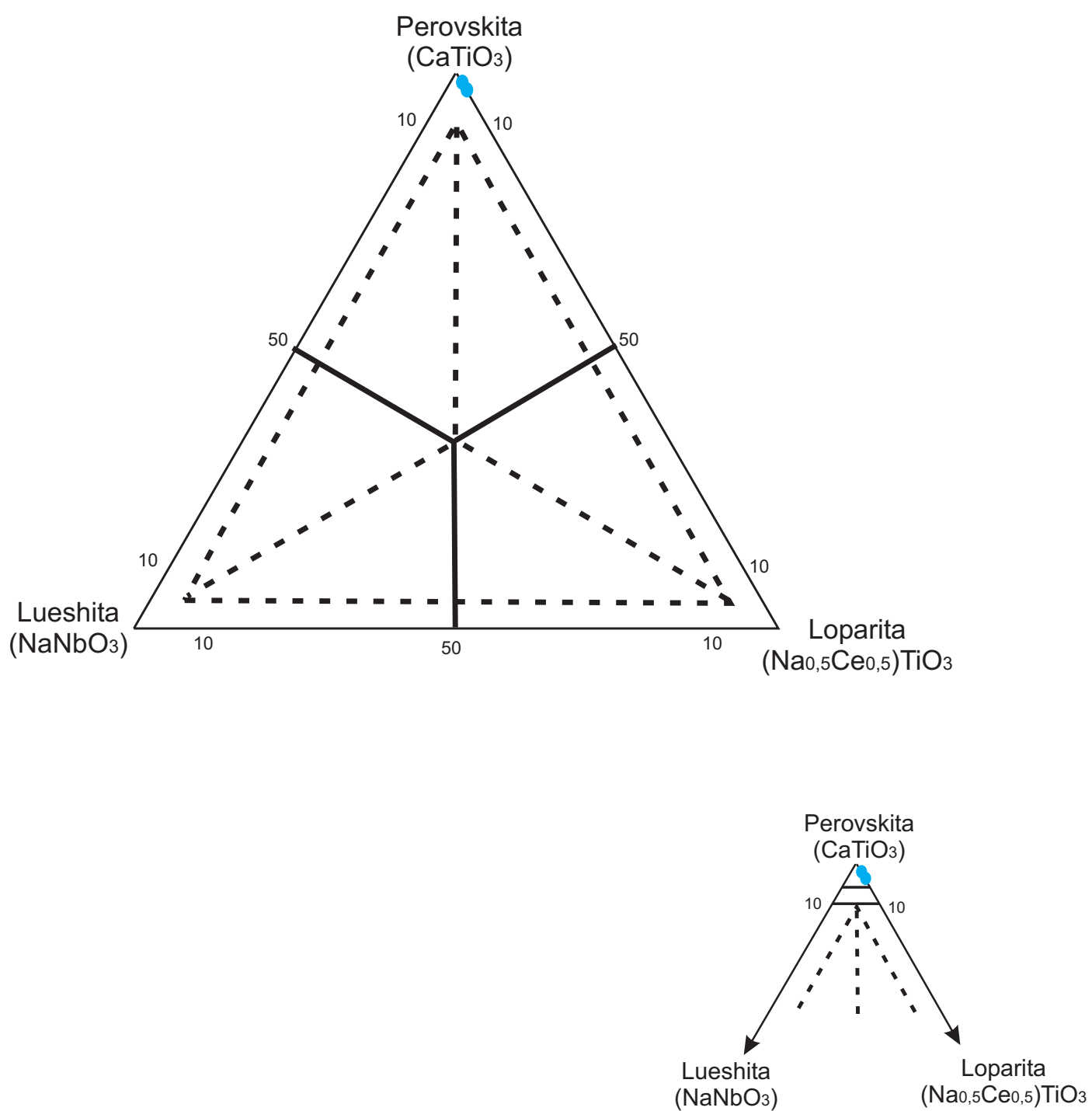

\section{LEGENDA}

- Perovskita da intrusão Indaiá II

Figura 33. Composição de perovskitas da intrusão Indaiá II (\% mol) no sistema perovskita - loparita lueshita. 
Tabela 21 - Composição química de perovskitas de Indaiá II. Abreviações: N, núcleo do grão; - abaixo do limite deteç̧ão.

\begin{tabular}{|c|c|c|c|c|c|c|c|c|c|c|c|c|c|c|c|c|c|c|c|c|c|c|c|c|c|}
\hline \multirow[b]{2}{*}{ Grão } & \multicolumn{13}{|c|}{$\mathrm{S} / \mathrm{N}$} & \multicolumn{12}{|c|}{$16 \mathrm{~A}$} \\
\hline & 01 & 02 & 03 & 04 & 05 & 06 & 07 & 08 & 09 & 10 & 11 & 12 & 13 & 14 & 15 & 16 & 17 & 18 & 19 & 20 & 21 & 22 & 23 & 24 & 25 \\
\hline $\mathrm{SiO} 2$ & - & - & 0,02 & - & 0,10 & - & - & - & - & - & - & - & - & - & - & - & 0,14 & - & - & - & - & - & - & - & - \\
\hline $\mathrm{CaO}$ & 37,68 & 38,16 & 38,42 & 38,10 & 38,73 & 38,54 & 37,23 & 37,53 & 38,50 & 38,89 & 38,92 & 38,32 & 37,86 & 37,89 & 38,45 & 37,77 & 38,64 & 38,60 & 38,25 & 38,40 & 37,92 & 38,90 & 38,28 & 37,56 & 38,27 \\
\hline $\mathrm{Y} 2 \mathrm{O} 3$ & 0,02 & 0,02 & 0,05 & 0,03 & 0,02 & 0,01 & - & 0,03 & 0,03 & 0,02 & 0,04 & 0,03 & 0,04 & 0,02 & 0,02 & 0,03 & 0,01 & 0,03 & 0,02 & 0,03 & 0,05 & 0,02 & 0,01 & 0,05 & 0,02 \\
\hline $\operatorname{Pr} 2 \mathrm{O} 3$ & 0,39 & 0,27 & 0,17 & 0,33 & 0,25 & 0,26 & 0,38 & 0,39 & 0,21 & 0,28 & 0,23 & 0,32 & 0,29 & 0,24 & 0,31 & 0,27 & 0,16 & 0,30 & 0,37 & 0,18 & 0,31 & 0,25 & 0,27 & 0,36 & 0,28 \\
\hline $\mathrm{La} 2 \mathrm{O} 3$ & 1,21 & 0,92 & 0,94 & 0,96 & 0,93 & 0,91 & 1,13 & 1,11 & 0,90 & 0,89 & 0,90 & 0,95 & 0,98 & 0,99 & 0,96 & 0,92 & 0,82 & 0,96 & 0,97 & 0,89 & 1,05 & 0,91 & 0,93 & 0,97 & 0,96 \\
\hline $\mathrm{Sm} 2 \mathrm{O} 3$ & 0,16 & 0,12 & 0,14 & 0,15 & 0,14 & 0,15 & 0,15 & 0,14 & 0,10 & 0,14 & 0,13 & 0,14 & 0,13 & 0,11 & 0,12 & 0,10 & 0,09 & 0,13 & 0,11 & 0,15 & 0,12 & 0,15 & 0,14 & 0,15 & 0,12 \\
\hline $\mathrm{Nd} 2 \mathrm{O} 3$ & 1,32 & 0,96 & 0,89 & 1,00 & 0,88 & 0,84 & 1,34 & 1,29 & 0,89 & 0,94 & 0,83 & 1,01 & 1,12 & 1,11 & 0,92 & 0,99 & 0,70 & 0,93 & 1,11 & 1,03 & 1,24 & 0,91 & 1,02 & 1,16 & 1,02 \\
\hline HfO2 & 0,01 & - & 0,02 & 0,01 & - & - & - & 0,02 & 0,03 & - & 0,01 & 0,02 & - & - & - & - & 0,04 & 0,02 & 0,01 & 0,03 & 0,02 & 0,01 & 0,01 & 0,02 & 0,04 \\
\hline $\mathrm{TiO} 2$ & 51,76 & 52,11 & 52,73 & 52,13 & 52,36 & 52,24 & 51,57 & 52,15 & 52,34 & 51,57 & 52,35 & 51,84 & 52,33 & 52,26 & 52,38 & 52,44 & 51,97 & 51,71 & 51,56 & 52,09 & 52,18 & 52,28 & 52,32 & 52,14 & 52,10 \\
\hline $\mathrm{FeO}$ & 2,08 & 2,08 & 1,79 & 2,16 & 2,08 & 2,22 & 2,05 & 2,05 & 2,10 & 2,15 & 2,13 & 2,18 & 2,18 & 2,16 & 2,01 & 2,12 & 2,20 & 2,11 & 2,16 & 2,19 & 1,85 & 2,08 & 2,23 & 2,13 & 2,23 \\
\hline $\mathrm{ZrO} 2$ & 0,10 & 0,10 & 0,09 & 0,09 & 0,07 & 0,10 & 0,09 & 0,09 & 0,16 & 0,11 & 0,09 & 0,10 & 0,10 & 0,09 & 0,07 & 0,11 & 0,19 & 0,10 & 0,08 & 0,12 & 0,11 & 0,12 & 0,09 & 0,13 & 0,07 \\
\hline $\mathrm{Nb} 2 \mathrm{O} 5$ & 0,44 & 0,40 & 0,50 & 0,35 & 0,42 & 0,35 & 0,47 & 0,42 & 0,42 & 0,37 & 0,41 & 0,38 & 0,35 & 0,38 & 0,36 & 0,38 & 0,53 & 0,49 & 0,36 & 0,35 & 0,49 & 0,37 & 0,36 & 0,32 & 0,39 \\
\hline UO2 & 0,04 & - & 0,03 & - & 0,06 & 0,02 & 0,04 & 0,01 & 0,03 & 0,02 & 0,02 & 0,04 & - & 0,03 & 0,03 & 0,02 & - & 0,02 & - & 0,05 & - & - & 0,02 & - & - \\
\hline $\mathrm{Ta} 2 \mathrm{O} 5$ & 0,08 & 0,01 & 0,05 & - & 0,02 & 0,04 & 0,08 & 0,04 & 0,02 & 0,06 & 0,06 & 0,08 & 0,03 & 0,07 & 0,05 & 0,03 & 0,05 & 0,03 & 0,06 & 0,08 & 0,05 & 0,07 & 0,08 & 0,06 & 0,06 \\
\hline ThO2 & 0,33 & 0,14 & 0,10 & 0,15 & 0,11 & 0,13 & 0,25 & 0,24 & 0,11 & 0,12 & 0,10 & 0,17 & 0,17 & 0,18 & 0,14 & 0,13 & 0,06 & 0,15 & 0,18 & 0,14 & 0,23 & 0,13 & 0,16 & 0,23 & 0,18 \\
\hline $\mathrm{SrO}$ & 0,50 & 0,48 & 0,72 & 0,52 & 0,59 & 0,54 & 0,45 & 0,49 & 0,50 & 0,55 & 0,53 & 0,54 & 0,45 & 0,55 & 0,53 & 0,52 & 0,78 & 0,56 & 0,51 & 0,52 & 0,49 & 0,64 & 0,56 & 0,48 & 0,53 \\
\hline Total & 100,04 & 98,78 & 99,30 & 98,85 & 99,42 & 99,07 & 98,81 & 99,49 & 99,18 & 98,83 & 99,23 & 99,24 & 99,18 & 99,08 & 99,28 & 98,67 & 98,88 & 98,86 & 98,95 & 99,01 & 99,42 & 99,52 & 99,35 & 99,08 & 99,26 \\
\hline $\mathrm{Fe} 2 \mathrm{O} 3$ & 2,31 & 2,31 & 1,98 & 2,40 & 2,31 & 2,47 & 2,28 & 2,28 & 2,33 & 2,38 & 2,37 & 2,42 & 2,43 & 2,39 & 2,24 & 2,36 & 2,44 & 2,34 & 2,40 & 2,43 & 2,06 & 2,31 & 2,48 & 2,36 & 2,47 \\
\hline $\mathrm{FeO}$ & - & - & - & - & - & - & - & - & - & - & - & - & - & - & - & - & - & - & - & - & - & - & - & - & - \\
\hline Total & 100,28 & 99,01 & 99,50 & 99,09 & 99,66 & 99,31 & 99,04 & 99,72 & 99,42 & 99,07 & 99,47 & 99,48 & 99,42 & 99,32 & 99,50 & 98,91 & 99,12 & 99,09 & 99,19 & 99,25 & 99,63 & 99,75 & 99,60 & 99,31 & 99,51 \\
\hline
\end{tabular}


Tabela 21 - Continuação

Fórmula Estrutural calculada na base de 03 oxigênios

\begin{tabular}{|c|c|c|c|c|c|c|c|c|c|c|c|c|c|c|c|c|c|c|c|c|c|c|c|c|c|}
\hline $\mathrm{Si}$ & - & - & & - & 0,002 & - & - & & - & - & $\begin{array}{lll}- & -\end{array}$ & $\begin{array}{ll}- \\
-\end{array}$ & - & - & 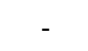 & - & 0,003 & - & - & - & - & - & - & & - \\
\hline $\mathrm{Ca}$ & 0,937 & 0,954 & 0,955 & 0,953 & 0,960 & 0,960 & 0,938 & 0,938 & 0,957 & 0,970 & 0,967 & 0,955 & 0,945 & 0,948 & 0,957 & 0,947 & 0,960 & 0,963 & 0,956 & 0,958 & 0,946 & 0,964 & 0,953 & 0,941 & 0,954 \\
\hline $\mathrm{Na}$ & 0,021 & 0,015 & 0,017 & 0,013 & 0,015 & 0,013 & 0,018 & 0,019 & 0,016 & 0,013 & 0,012 & 0,016 & 0,015 & 0,014 & 0,014 & 0,014 & 0,021 & 0,018 & 0,015 & 0,013 & 0,019 & 0,014 & 0,014 & 0,016 & 0,015 \\
\hline $\mathrm{Sr}$ & 0,007 & 0,006 & 0,010 & 0,007 & 0,008 & 0,007 & 0,006 & 0,007 & 0,007 & 0,007 & 0,007 & 0,007 & 0,006 & 0,007 & 0,007 & 0,007 & 0,010 & 0,008 & 0,007 & 0,007 & 0,007 & 0,009 & 0,008 & 0,007 & 0,007 \\
\hline $\mathrm{Y}$ & - & - & 0,001 & - & - & - & - & - & - & - & 0,001 & - & - & - & - & - & - & - & - & - & 0,001 & - & - & 0,001 & - \\
\hline $\mathrm{La}$ & 0,010 & 0,008 & 0,008 & 0,008 & 0,008 & 0,008 & 0,010 & 0,010 & 0,008 & 0,008 & 0,008 & 0,008 & 0,008 & 0,009 & 0,008 & 0,008 & 0,007 & 0,008 & 0,008 & 0,008 & 0,009 & 0,008 & 0,008 & 0,008 & 0,008 \\
\hline $\mathrm{Ce}$ & 0,056 & 0,043 & 0,037 & 0,042 & 0,038 & 0,039 & 0,052 & 0,050 & 0,040 & 0,040 & 0,036 & 0,045 & 0,046 & 0,044 & 0,042 & 0,041 & 0,033 & 0,038 & 0,047 & 0,040 & 0,047 & 0,038 & 0,041 & 0,049 & 0,043 \\
\hline $\operatorname{Pr}$ & 0,003 & 0,002 & 0,001 & 0,003 & 0,002 & 0,002 & 0,003 & 0,003 & 0,002 & 0,002 & 0,002 & 0,003 & 0,002 & 0,002 & 0,003 & 0,002 & 0,001 & 0,003 & 0,003 & 0,002 & 0,003 & 0,002 & 0,002 & 0,003 & 0,002 \\
\hline $\mathrm{Nd}$ & 0,011 & 0,008 & 0,007 & 0,008 & 0,007 & 0,007 & 0,011 & 0,011 & 0,007 & 0,008 & 0,007 & 0,008 & 0,009 & 0,009 & 0,008 & 0,008 & 0,006 & 0,008 & 0,009 & 0,009 & 0,010 & 0,008 & 0,008 & 0,010 & 0,008 \\
\hline $\mathrm{Sm}$ & 0,001 & 0,001 & 0,001 & 0,001 & 0,001 & 0,001 & 0,001 & 0,001 & 0,001 & 0,001 & 0,001 & 0,001 & 0,001 & 0,001 & 0,001 & 0,001 & 0,001 & 0,001 & 0,001 & 0,001 & 0,001 & 0,001 & 0,001 & 0,001 & 0,001 \\
\hline Sítio A & 1,047 & 1,039 & 1,037 & 1,036 & 1,042 & 1,038 & 1,039 & 1,038 & 1,038 & 1,049 & 1,040 & 1,044 & 1,034 & 1,033 & 1,040 & 1,029 & 1,042 & 1,046 & 1,047 & 1,038 & 1,042 & 1,044 & 1,036 & 1,035 & 1,039 \\
\hline $\mathrm{Ti}$ & 0,904 & 0,915 & 0,920 & 0,916 & 0,912 & 0,913 & 0,912 & 0,915 & 0,914 & 0,903 & 0,913 & 0,907 & 0,917 & 0,918 & 0,915 & 0,923 & 0,907 & 0,905 & 0,905 & 0,913 & 0,914 & 0,910 & 0,915 & 0,917 & 0,911 \\
\hline $\mathrm{Nb}$ & 0,005 & 0,004 & 0,005 & 0,004 & 0,004 & 0,004 & 0,005 & 0,004 & 0,004 & 0,004 & 0,004 & 0,004 & 0,004 & 0,004 & 0,004 & 0,004 & 0,006 & 0,005 & 0,004 & 0,004 & 0,005 & 0,004 & 0,004 & 0,003 & 0,004 \\
\hline $\mathrm{Fe} 3+$ & 0,041 & 0,041 & 0,035 & 0,043 & 0,041 & 0,044 & 0,041 & 0,041 & 0,042 & 0,043 & 0,042 & 0,043 & 0,043 & 0,043 & 0,040 & 0,042 & 0,044 & 0,042 & 0,043 & 0,043 & 0,037 & 0,041 & 0,044 & 0,042 & 0,044 \\
\hline $\mathrm{Fe} 2+$ & - & - & - & - & - & - & - & - & - & - & - & - & - & - & - & - & - & - & - & - & - & - & - & - & - \\
\hline $\mathrm{Mn}$ & - & - & - & - & - & - & - & - & - & - & - & - & - & - & - & - & - & - & - & - & - & - & - & - & - \\
\hline $\mathrm{Ta}$ & 0,001 & - & - & - & - & - & - & - & - & - & - & 0,001 & - & - & - & - & - & - & - & - & - & - & 0,001 & - & - \\
\hline Th & 0,002 & 0,001 & 0,001 & 0,001 & 0,001 & 0,001 & 0,001 & 0,001 & 0,001 & 0,001 & 0,001 & 0,001 & 0,001 & 0,001 & 0,001 & 0,001 & - & 0,001 & 0,001 & 0,001 & 0,001 & 0,001 & 0,001 & 0,001 & 0,001 \\
\hline $\mathrm{Zr}$ & 0,001 & 0,001 & 0,001 & 0,001 & 0,001 & 0,001 & 0,001 & 0,001 & 0,002 & 0,001 & 0,001 & 0,001 & 0,001 & 0,001 & 0,001 & 0,001 & 0,002 & 0,001 & 0,001 & 0,001 & 0,001 & 0,001 & 0,001 & 0,001 & 0,001 \\
\hline $\mathrm{Hf}$ & - & - & - & - & - & - & - & - & - & - & - & - & - & - & - & - & - & - & - & - & - & - & - & - & - \\
\hline $\mathrm{U}$ & - & - & - & - & - & - & - & - & - & - & - & - & - & - & - & - & - & - & - & - & - & - & - & - & - \\
\hline Sitio B & 0,953 & 0,962 & 0,963 & 0,964 & 0,959 & 0,963 & 0,961 & 0,963 & 0,963 & 0,952 & 0,961 & 0,957 & 0,966 & 0,967 & 0,961 & 0,972 & 0,959 & 0,955 & 0,954 & 0,963 & 0,959 & 0,957 & 0,965 & 0,966 & 0,962 \\
\hline Cátions & 2,001 & 2,001 & 2,001 & 2,001 & 2,001 & 2,001 & 2,001 & 2,001 & 2,001 & 2,001 & 2,001 & 2,001 & 2,001 & 2,001 & 2,001 & 2,001 & 2,001 & 2,001 & 2,001 & 2,001 & 2,001 & 2,001 & 2,001 & 2,001 & 2,001 \\
\hline rovskita & 91,87 & 92,24 & 93,70 & 91,39 & 93,22 & 91,96 & 91,04 & 91,01 & 92,63 & 93,42 & 93,18 & 92,53 & 90,50 & 90,68 & 92,81 & 90,08 & 91,82 & 92,65 & 92,59 & 91,69 & 93,00 & 93,22 & 90,77 & 90,13 & 91,29 \\
\hline Catrappita & 4,41 & 4,37 & 3,73 & 4,52 & 4,36 & 4,65 & 4,36 & 4,32 & 4,40 & 4,54 & 4,45 & 4,61 & 4,56 & 4,50 & 4,21 & 4,40 & 4,62 & 4,47 & 4,58 & 4,58 & 3,91 & 4,33 & 4,64 & 4,44 & 4,65 \\
\hline Loparita & 2,24 & 1,62 & 1,76 & 1,38 & 1,57 & 1,41 & 1,91 & 2,00 & 1,66 & 1,35 & 1,29 & 1,66 & 1,59 & 1,44 & 1,43 & 1,51 & 2,18 & 1,88 & 1,60 & 1,34 & 2,03 & 1,48 & 1,43 & 1,64 & 1,54 \\
\hline $\mathrm{La} 2 \mathrm{Ti} 2 \mathrm{O} 7$ & 0,75 & 0,84 & 0,24 & 0,87 & 0,39 & 0,83 & 1,05 & 1,02 & 0,82 & - & 0,63 & 0,77 & 0,89 & 0,89 & 0,87 & 0,83 & - & - & 0,50 & 0,80 & 0,35 & - & 0,84 & 0,88 & 0,87 \\
\hline $\mathrm{Ce} 2 \mathrm{Ti} 2 \mathrm{O} 7$ & - & 0,48 & - & 1,44 & - & 0,76 & 1,10 & 1,18 & 0,02 & - & - & - & 2,08 & 2,07 & 0,28 & 2,45 & - & - & - & 0,85 & - & - & 1,53 & 2,22 & 0,90 \\
\hline $\mathrm{CaZrO} 3$ & - & - & - & - & - & - & - & - & - & 0,13 & - & - & - & - & - & - & 0,23 & 0,12 & - & - & - & 0,06 & - & - & - \\
\hline $\mathrm{aThO} 3$ & - & - & - & - & - & - & - & - & - & 0,13 & - & - & - & - & - & - & 0,03 & 0,08 & - & - & - & - & - & - & - \\
\hline $2 \mathrm{Nb} 2 \mathrm{O} 7$ & 0,49 & 0,44 & 0,56 & 0,39 & 0,46 & 0,39 & 0,53 & 0,47 & 0,46 & 0,42 & 0,45 & 0,43 & 0,38 & 0,42 & 0,40 & 0,42 & 0,59 & 0,55 & 0,40 & 0,38 & 0,55 & 0,41 & 0,40 & 0,36 & 0,43 \\
\hline $2 \mathrm{Ta} 2 \mathrm{O} 7$ & 0,23 & - & - & - & - & - & - & - & - & - & - & - & - & - & - & 0,31 & 0,52 & 0,25 & 0,32 & 0,36 & 0,16 & 0,49 & 0,39 & 0,33 & 0,32 \\
\hline
\end{tabular}




\section{Considerações petrográficas e mineralógicas das Intrusões estudadas}

\subsection{Comparação entre as intrusões Indaiá I e Indaiá II}

Visando um detalhamento maior das características mineralógicas e texturais intrínsecas de cada intrusão, a seguir, será apresentada breve comparação dos dados obtidos, inicialmente comparando-se macro e microscopicamente as variedades litológicas, prosseguindo com as características químicas dos minerais analisados.

\subsubsection{Comparação das características petrográficas}

Rochas ígneas são comumente classificadas usando a combinação de critérios mineralógicos, modais e texturais. Apesar de tais critérios serem apropriados para rochas ígneas mais comuns, eles são considerados (Mitchell \& Bergman 1991, Scott-Smith 1992, Mitchell 1994, Wooley et al. 1995) inadequados para kimberlitos, lamproítos, kamafugitos, orangeitos e lamprófiros. Muitas destas rochas não podem ser identificadas usando classificações modais/texturais padrões, seja no campo ou no laboratório. Kimberlitos, lamproítos, kamafugitos e orangeítos são muito parecidos em sua aparência macroscópica e petrográfica. Rochas alteradas apresentam desafios particulares sendo extremamente difícil, se não impossível, classificar corretamente rochas dessa natureza usando simples critérios petrográficos (Mitchell, 1991). Contudo, a petrografia, dentro de seus limites, continua insubstituível, particularmente nas etapas que antecedem o uso da microssonda.

As características macroscópicas das amostras da intrusão Indaiá I, confrontadas a tipologias congêneres da literatura e de outros corpos conhecidos na região, são comparáveis a uma brecha kimberlítica macrocristalina. A rocha possui a alta porcentagem de megacristais, macrocristais, fenocristais de minerais máficos e abundante xenólitos ultramáfico mantélico além de outros, imersos em uma matriz afanítica. Já as rochas da intrusão Indaiá II têm uma baixa porcentagem desses tipos texturais de cristais e xenólitos, sendo assim com maior presença de matriz afanítica. Essas feições texturais assemelham-se mais a fácies intermediárias entre um kimberlito afanítico e kimberlito macrocristalino.

Com base nas características macroscópicas descritas acima considera-se, grosso modo, que as rochas de Indaiá I e II são kimberlitos sensu lato. Segundo a classificação genéticatextural de Clement \& Skinner (1985), que atribui as terminologias fácies cratera (e.g. lavas, rochas piroclásticas e vulcanoclásticas), fácies diatrema (porção afunilada disposta abaixo da fácies cratera) e fácies hipoabissal (diques e sills formando a zona da raiz da intrusão), conforme a textura e estrutura dessas rochas, as amostras pesquisadas de ambas as intrusões podem ser classificadas como pertencentes a fácies hipoabissal ou seja, é possível que ambas 
sejam resultado de cristalização "normal” de um magma kimberlítico, porém com posicionamento distinto na compartimentação da estrutura da intrusão que se reflete como consequência nas diferenças texturais.

Do ponto de vista microscópico, a comparação entre os litotipos associados com as intrusões Indaiá I e Indaiá II permite destacar as seguintes feições petrográficas:

As rochas de Indaiá I possui aproximadamente $20 \%$ mais mega/macro/fenocristais e xenólitos do que a intrusão II. Na intrusão I, a matriz ( $40 \%$ vol) das rochas compõe-se de olivina, minerais opacos, monticellita, perovskita e clinopiroxênio (diopsídio), além de carbonatos intersticiais, enquanto na intrusão II, a matriz (55\%) representa uma assembléia mineral complexa, contendo microfenocristais de clinopiroxênio diopsídico esverdeado, minerais opacos, comumente associados a espinélio avermelhado, perovskita e olivina, com raro vidro intersticial (devitrificado).

Os litotipos de Indaiá I apresentam duas populações de grãos minerais, uma formada por cristais pequenos da matriz e outra de granularidade crescente, que se estende desde microfenocristais $(0,5 \mathrm{~mm})$ até megacristais de $20 \mathrm{~mm}$, sendo texturalmente classificada de rocha porfirítica seriada. Já em Indaiá II, a granularidade bimodal (grãos de 8 a $10 \mathrm{~mm}$ em matriz fina) melhor definida permite classificar como rocha porfirítica. Microvenulações e texturas de fluxo são feições observadas somente na intrusão II.

A intrusão I é caracterizada por uma assembléia mineral muito mais enriquecida em olivina (o dobro em volume) em relação à intrusão II, com os cristais bordejados por bowlingita ou clorofaeita, alguns deles zonados; na segunda, os cristais comumente apresentam texturas de embayament, numa clara evidência de assimilação pelo magma.

Por outro lado, piroxênios diopsídicos (30\% modal) e perovskitas das rochas de Indaiá II são abundantes, representando um volume respectivamente da ordem de oito e três vezes maior do que os de Indaiá I. Aqui, os poucos piroxênios registrados são de dois tipos, um diopsídico que ocorre como componente da matriz (4\%) e outro, um ortopiroxênio, na forma de raros fenocristais pertencentes ao grupo da enstatita - ferrossilita.

Monticellita e melilita só foram observadas na intrusão I, onde ocorrem também quantidades bem maiores de fenocristais e microfenocristais de opacos, cerca de $75 \%$ mais do que na intrusão II.

Ilmenita encontra-se presente nas duas intrusões e sua presença foi confirmada com EDS e determinações por microssonda (WDS). Na intrusão de Indaiá I, ela aparece nos xenólitos de dunito e piroxenito e na rocha hospedeira na forma de fenocristais, inclusões em cristais de olivina e na matriz. Em Indaiá II, a ilmenita ocorre nos xenólitos de dunito e na matriz da rocha hospedeira. 
Em ambas as ocorrências foi registrada a presença de xenólitos mantélicos de dunito, ressaltando que em igual abundância, porém arredondados na intrusão I e angulosos e levemente estirados na intrusão II. Os raros xenólitos piroxeníticos só foram observados na intrusão I, enquanto xenólitos microcristalinos e nefeliníticos parecem exclusivos da intrusão II. Nas duas intrusões ocorrem variadas quantidades de xenólitos de lapilli (o dobro em Indaiá II) e de carbonatitos (o dobro em Indaiá I).

\subsubsection{Comparação entre a química mineral}

A olivina das rochas de Indaiá I e Indaiá II contém elevado conteúdo de Fo $\left(\mathrm{Mg} / \mathrm{Mg}+\mathrm{Fe}^{2+} 0,83\right.$ a 0,95$)$ e geralmente não apresenta diferenças significativas para o Fo médio dos tipos texturais dos grãos. Os valores algo mais elevados são encontrados geralmente nos macrocristais da intrusão Indaiá $\mathrm{I}\left(\mathrm{Mg} / \mathrm{Mg}+\mathrm{Fe}^{2+} 0,84\right.$ a 0,95$)$ e fenocristais de Indaiá II $\left(\mathrm{Mg} / \mathrm{Mg}+\mathrm{Fe}^{2+} 0,87\right.$ a 0,93$)$. O mineral mostra concentração expressiva em $\mathrm{NiO}$ nos diversos tipos texturais, predominantemente nos intervalos entre 0,10 e 0,27\%. $\mathrm{CaO}$ é sempre inferior a $0,30 \%$, com Al sempre próximos ao limite de detecção. Nos xenolitos, a olivina mostra similar tendência composicional, com mg\# em torno de 0,88 e $\mathrm{NiO}$ de 0,12 e $\mathrm{CaO}$ de 0,37 .

O piroxênio presente na assembléia mineral das duas intrusões tem composição diferenciada. Na intrusão I, o mineral está representado por dois tipos bem distintos que se reflete na textura dos grãos: ortopiroxênios da série enstatita - ferrossilita destacam-se como macrocristais, sendo caracterizados por $\mathrm{Mg} / \mathrm{Mg}+\mathrm{Fe}^{2+}$ elevado (entre 0,86 e 0,92), com teores apreciáveis de $\mathrm{Cr}_{2} \mathrm{O}_{3}$ (até 0,52\%) e baixo de $\mathrm{CaO}\left(0,3\right.$ a 1,5\%), $\mathrm{Al}_{2} \mathrm{O}_{3}\left(0,06\right.$ a 0,99\%) e $\mathrm{Na}_{2} \mathrm{O}$ $(<0,2 \%)$; e clinopiroxênios verdes, da série diopsídio-hedenbegita, que compõem os minerais da matriz. Na intrusão Indaiá II, todos piroxênios têm composição situada no campo do diopsídio $\left(\mathrm{Mg} / \mathrm{Mg}+\mathrm{Fe}^{2+}\right.$ de 0,83 a 0,88 em microfenocristais e de 0,82 a 0,96 na matriz). No entanto, os cristais da matriz apresentam teores mais baixos de $\mathrm{CaO}\left(21,58\right.$ a 23,99\%) e $\mathrm{Al}_{2} \mathrm{O}_{3}$ $\left(0,19\right.$ a 0,41\%) e mais elevados de $\mathrm{Na}_{2} \mathrm{O}(0,94$ a $1,88 \%)$, relativamente aos dos microfenocristais ( $\mathrm{CaO}$ de 24,34 a 24,71\%, $\mathrm{Al}_{2} \mathrm{O}_{3}$ de 0,9 a $1,46 \%$ e $\mathrm{Na}_{2} \mathrm{O}$ de 0,22 a $0,30 \%$ ); $\mathrm{Cr}_{2} \mathrm{O}_{3}(<0,12 \%)$ se mantém sempre muito baixo.

Por outro lado, nos xenólitos das intrusões I e II, os piroxênios também possuem composição de diopsídio $\left(\mathrm{Mg} / \mathrm{Mg}+\mathrm{Fe}^{2+}\right.$ de 0,84 a 0,89 e de 1,00 respectivamente). Nos xenólitos da intrusão II, eles são em tudo comparáveis aos microfenocristais da rocha hospedeira, enquanto na intrusão $\mathrm{I}$, os piroxênios são relativamente algo mais ricos em $\mathrm{Cr}_{2} \mathrm{O}_{3}$ (até $0,45 \%$ ) e $\mathrm{Na}_{2} \mathrm{O}$ (até $0,92 \%$ ). 
Nas duas intrusões, a ilmenita possui elevado teor de $\operatorname{MgO}(7,2$ a 14,56\%), independentemente dos tipos texturais dos grãos ou da rocha em que se encontra. Os valores mais elevados são encontrados nos cristais de xenólitos de dunitos e da matriz das respectivas rochas hospedeiras que formam as duas intrusões, enquanto que os mais baixos foram creditados aos cristais de xenólito de piroxenitos, de inclusões em olivina e de alguns da matriz, todos estes da intrusão I. Essas características permitem classificar o mineral de ilmenita magnesiana. Destaca-se, também, as concentrações invariavelmente elevadas de $\mathrm{Cr}_{2} \mathrm{O}_{3}\left(0,81\right.$ a 5,06\%) e apreciáveis de $\mathrm{Nb}_{2} \mathrm{O}_{5}(0,07$ a 1,08\%), com seus extremos refletindo a composição dos macrocristais da ilmenita magnesiana de Indaiá I.

Minerais do grupo dos espinélios portadores de $\mathrm{Cr}$ são comuns e têm uma variação química importante nos kimberlitos, sendo menos importantes nos kamafugitos. Na intrusão de Indaiá I, os minerais desse grupo acham-se presentes como inclusões em olivina e constituintes da matriz da rocha, e nos xenólitos de carbonatito e no lapilli, enquanto na intrusão de Indaiá II encontram-se na matriz da rocha e como inclusão em olivina. Na intrusão I, esses minerais exibem sempre teores elevados de $\mathrm{Cr}_{2} \mathrm{O}_{3}(33,52$ a 50,06\%) e $\mathrm{MgO}(11,72$ a $15,17 \%)$, porém com teores de $\mathrm{Al}_{2} \mathrm{O}_{3}$ em parte baixo $(<6 \%)$ e em parte alto $(>30 \%)$. Essas características permitem classificar tais minerais em, respectivamente, cromita (presentes na matriz e nos xenólitos) e Cr-espinélios (matriz e inclusão em olivina). Além disso, ocorre também membros da série ulvöespinélio-magnetita, com $\mathrm{TiO}_{2}$ e $\mathrm{MgO}$ respectivamente alto $(10,66$ a 16,08) e $(10,52$ a 16,15) na matriz e baixo $(4.09)$ e $(2,76)$ em inclusão de olivina. $\mathrm{Na}$ intrusão II, os minerais do grupo do espinélios são caracterizados pelos teores baixos de $\mathrm{Al}_{2} \mathrm{O}_{3}$ $(0,10$ a 3,2\%) e $\mathrm{MgO}(4,05$ a 5,76\%, exceto uma análise com 16,19\%) e extensamente variáveis de $\mathrm{Cr}_{2} \mathrm{O}_{3}\left(0,91\right.$ a 31,90\%) e $\mathrm{TiO}_{2}$ (5,53 a 16,08\%), sendo assim classificados em magnetita\Ti-magnetita (matriz e inclusão de olivina) e cromita (matriz).

A perovskita registrada nas duas intrusões tem composição similar e próxima à da fórmula ideal, representada pelo end-member perovskita (CaTiO3, de 90,08 a 94,29 \%mol). A estrutura é completada com outros componentes moleculares, principalmente a loparita e latrappita, representando geralmente teores menores que 9,92\%mol. Outras características observadas nas perovskitas de Indaiá I e Indaiá II são, respectivamente, os teores expressivos de $\mathrm{Ce}_{2} \mathrm{O}_{3}\left(1,41\right.$ - 4,62\%, intrusão I; 2,04 - 3,46,\% intrusão II), $\mathrm{Nb}_{2} \mathrm{O}_{3}(0,34-1,65 \%$; 0,32 $0,53 \%), \mathrm{Na}_{2} \mathrm{O}(0,29-0,84 \% ; 0,27-0,46 \%), \mathrm{SrO}(0,35-0,70 \% ; 0,45-0,78 \%)$ e FeO $(1,30-$ $2,61 \% ; 1,85-2,23 \%)$. Destaque-se que estas perovskitas sempre mantém a relação de teores Ce $>$ La. 


\subsection{A nomenclatura das rochas máfica-ultramáficas, potássica - ultrapotássicas:} kimberlitos, orangeitos, lamproítos, kamafugitos e lamprófiros

Visando à correta classificação das rochas estudadas, enriquecendo a discussão que se seguirá, será apresentada um síntese das principais características que definem uma rocha de natureza máfica-ultramáficas, potássica-ultrapotássica, pertencentes aos clãs dos kimberlitos, orangeítos, lamproítos, kamafugitos e lamprófiros, antes mesmo da discussão entre os resultados obtidos neste trabalho e comparação com dados disponíveis na vasta literatura pertinente ao assunto.

\subsubsection{Kimberlitos}

Kimberlito é uma rocha ultramáfica $(\mathrm{MgO}=15-40 \%$, Dawson 1980), potássica, rica em voláteis (dominantemente $\mathrm{CO}_{2}$, Clement et al. 1984, Mitchell 1995), que ocorre segundo Hawthorne (1975) como corpos de forma cônica invertida, "pipes" ou diatremas (Figura 34 A). Os diatremas kimberlíticos possuem uma estrutura definida, que pode ser compartimentada segundo três fácies principais: a) fácies cratera, porções dos níveis mais superficiais, onde se observa material kimberlítico (lavas, rochas piroclásticas e vulcanoclásticas ressedimentas) associado a sedimentos de origem flúvio-lacustre (epiclásticos); b) fácies diatrema, representado por corpos afunilados dos níveis abaixo da fácies cratera, ricos em xenólitos do manto superior, como também das rochas encaixantes; e c) fácies hipoabissal, que compreende a zona de raiz do diatrema, caracterizada pela abundância de diques e sills (Hawthorne 1975).

Os kimberlitos são rochas caracterizadas por uma textura inequigranular distintiva, como resultado da presença de megacristais $(>10 \mathrm{~mm})$ e macrocristais $(0,5$ a $10 \mathrm{~mm})$ imersos em uma matriz fina-granulada (Mitchell 1986, 1995). Essa matriz compõe-se principalmente de olivina, flogopita, calcita, serpentina, diopsídio, monticellita, apatita, espinélio-titanífero, perovskita, cromita e ilmenita (Clement et al. 1984).

Alterações deutéricas e metassomáticas são comuns nos kimberlitos, tornando-se muito difícil a sua classificação petrográfica (Gonzaga \& Tompkins 1991).

Os critérios petrográficos e mineralógicos para classificação nem sempre são satisfatórios, tendo em vista que as estruturas, texturas e macrocristais definidos podem estar ausentes em kimberlitos diferenciados. Um critério individual ou isoladamente, não é necessariamente diagnóstico. Antes de decidir sobre a natureza das amostras estudadas, devem ser consideradas a assembléia mineral e sua variação composicional como um todo. 
Segundo Mitchell (1995), os kimberlitos não podem ser identificados somente por uma base petrográfica.

As investigações geoquímicas de kimberlitos são muito difíceis, devido à contaminação pelo material da crosta e água subterrânea. O melhor material para estudos geoquímicos são aqueles procedentes de fácies hipoabissal. Segundo Mitchell (1986), a composição de rochas kimberlíticas sem contaminação é caracterizada por teores baixos de $\mathrm{Al}_{2} \mathrm{O}_{3}(<0,5 \%)$ e variáveis de $\mathrm{SiO}_{2}$ (25-35\%). O caráter marcante dos kimberlitos são os teores baixos de $\mathrm{Na}_{2} \mathrm{O}$ e as razões $\mathrm{Na}_{2} \mathrm{O} / \mathrm{K}_{2} \mathrm{O}<0,5$.

Os estudos de isótopos radiogênicos indicam razões iniciais de ${ }^{87} \mathrm{Sr} /{ }^{86} \mathrm{Sr}$ no intervalo de 0,706-0716. Os valores elevados são atribuídos às alterações dos kimberlitos (Mitchell 1986). Estudos de razões iniciais de ${ }^{143} \mathrm{Nd} /{ }^{144} \mathrm{Nd}$, ou $\in \mathrm{Nd}$ mostram que os kimberlitos estão reunidos em dois grupos (Smith, 1983):

Grupo I, considerados kimberlitos verdadeiros, com valores de $\in \mathrm{Nd}$ de $(-0,5)$ a $(+0,6)$, e de ${ }^{87} \mathrm{Sr} /{ }^{86} \mathrm{Sr}$ de 0,703 a 0,705 . Estes inclui os tipos serpentina-kimberlito, monticellitakimberlito e calcita-kimberlito.

Grupo II, denominados orangeitos, com valores de $\in \mathrm{Nd}$ de $(-7)$ a $(-12)$ e ${ }^{87} \mathrm{Sr} /{ }^{86} \mathrm{Sr}$ de 0,707 a 0,711 . Estes inclui predominantemente os kimberlitos micáceos.

\subsubsection{Orangeitos}

Orangeitos, ou kimberlitos do Grupo II (Smith 1983; Woolley et al., 1996), são rochas ultrapotássicas peralcalinas, ricas em voláteis (dominantemente $\mathrm{H}_{2} \mathrm{O}$ ), caracterizadas por apresentar macrocristais e microfenocristais de flogopita que, juntamente com as micas da matriz, possuem composição de flogopita a tetraferriflogopita. Macrocristais de olivina arredondada e cristais primários euédricos de são também comuns, mas nem sempre são os maiores constituintes. As fases primárias de matriz são representadas por: diopsídio, comumente zonado ou manteado por Ti-aegirina; espinélio (Mg-cromita a Ti-magnetita); perovskita rica em Sr e ETR; apatita rica em Sr; fosfatos (monazita, daqingshanita) ricos em ETR; (K, Ba), titanatos pertencentes ao grupo da hollandita; K-triskaidecatitanatos; Nb-rutilo; Mn-ilmenita. A mesóstase pode conter calcita, dolomita, ancylita e outros carbonatos de ETR, witherita, norsethita e serpentina. Os membros evoluídos do grupo contêm na matriz sanidina e K-richterita. Zr-silicatos (wadeita, zircão, granadas kinzeíticas, Ca-Zr silicatos) podem também ocorrer na matriz como minerais tardios. Barita pode ocorrer como mineral secundário. 


\subsubsection{Lamproítos}

Lamproíto é uma rocha ígnea, ultrapotássica $\left(\mathrm{K}_{2} \mathrm{O} / \mathrm{Na}_{2} \mathrm{O}>5\right.$, Mitchell 1985), peralcalina, rica em magnésio e constituída, em diferentes proporções (5 a 90\%vol), de flogopita, titâniopotássio richterita, olivina forsterítica, diopsídio pobre em $\mathrm{Al} \mathrm{e} \mathrm{Na}$, sanidina rica em ferro e leucita não estequiométrica rica em ferro; vidro encontra-se presente em muitos lamproítos, porém, o mesmo não faz parte da definição de lamproíto por não se tratar de mineral senso estrito (Mitchell 1985).

Os aspectos petrográficos característicos dos lamproítos são a ocorrência de flogopita como fenocristal ou placas poiquilíticas na matriz e/ou cristalização tardia de richteritatitanífera-potássica (Mitchell 1985). Fases menores e comuns acessórios incluem priderita, wadeita, perovskita, magnesiocromita, titano-magnesiocromita e magnesio-titanomagnetita.

A presença de alguns minerais excluem a rocha do grupo dos lamproítos, tais como plagioclásio primário, feldspato alcalino sódico, monticellita, nefelina, kalsilita, melilita, sodalita, noseana, hauyna, melanita, schorlomita ou kimzeyta (Wooley et al., 1996).

A nomenclatura das rochas lamproíticas é bastante complexa, havendo várias denominações. Como na nomenclatura dos kimberlitos, Scott-Smith \& Skinner (1984) propuseram que os lamproítos sejam divididos em grupos, com as fases minerais dominantes determinando o nome da rocha.

Os lamproítos ocorrem numa estrutura em forma de taça (Figura 34B), com uma fácies de cratera, recoberta na superfície por sedimentos flúvio-lacustres e material vulcânico associado, e uma fácies ígnea tardia, com menos voláteis do que a fácies cratera (Gonzaga \& Tompkins, 1991). 
Figuras 34 (A e B). Modelos de estruturas intrusivas de pipes kimberlíticos (A) e lamproíticos (B) (Extraído de Mitchell, 1986).
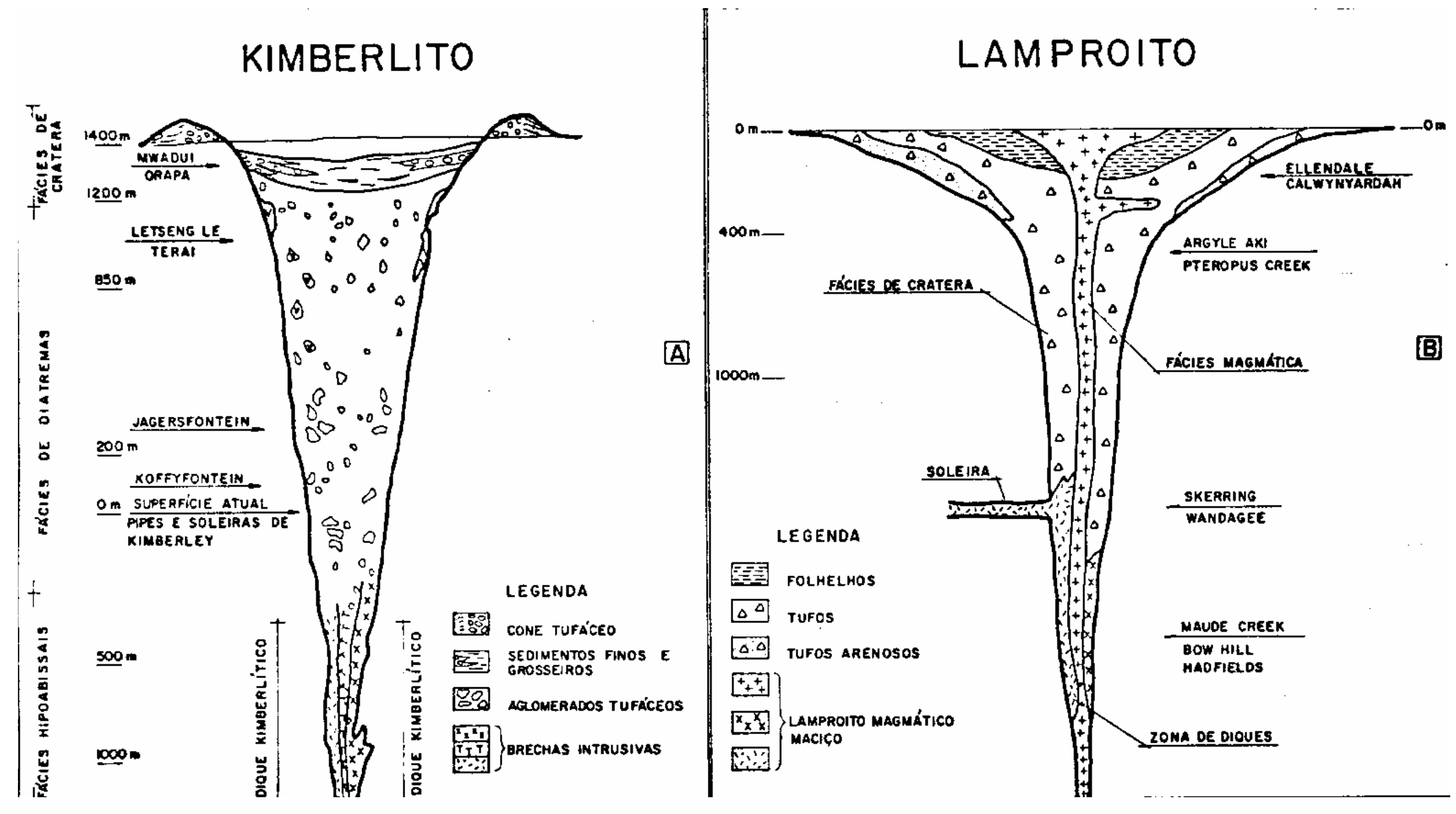


\subsubsection{Kamafugitos}

Kamafugito é um termo coletivo que engloba uma série de rochas vulcânicas máficas a ultramáficas, subsaturadas em sílica, cujas fases félsicas são compostas por feldspatóides (kalsilita e/ou nefelina e/ou leucita; Wooley et al. 1996 e Sgarbi et al. 2001). São rochas bastante raras, que ocorre reconhecidamente no braço oeste do Rift do Leste Africano, ao longo da fronteira sudoeste entre Uganda e Zaire (Lloyd et al. 1991), na margem nordeste da Província Romana (San Venanzo e Cupaello), e na PIAP, ao redor das cidades de Coromandel, ao norte, e Bambuí, ao Sul (Sgarbi et al. 2001).

O termo kamafugito é um acrônimo das principais rochas que compõem a série: katungito, mafurito e ugandito.

Os kamafugitos rochas cinza claras a preto-esverdeada, afaníticas a faneríticas finas, porfíríticas ou não. São dois os tipos litológicos principais: mafuritos e uganditos (Sgarbi \& Valença 1999, Sgarbi et al. 2001).

No Brasil o vulcanismo kamafugítico acha-se representado nas sub-províncias Mata da Corda e Alto Paranaíba, na Bacia Sanfranciscana em Minas Gerais e nas sub-províncias Santo Antônio da Barra e Iporá em Goiás (Sgarbi et al. 2001).

Mafuritos são rochas porfiríticas, de matriz fina a muito fina, com fenocristais $(0,2$ a 2,5mm; exceto plaquetas de flogopita $>3,0 \mathrm{~cm}$ ) de olivina, clinopiroxênio, Ti-magnetita, perovskita, melilita (pseudomorfos), apatita e, muito raramente flogopita. A matriz é microcristalina e compõe-se de piroxênio, Ti-magnetita e perovskita, podendo conter, ainda, flogopita, apatita e material intersticial, em geral muito alterado. Em algumas rochas, os interstícios são preenchidos por feldspatóides, identificados como kalsilita (Sgarbi \& Valença 1993). Algumas rochas apresentam material intersticial formado de massa argilosa esmectítica resultante da alteração de vidro vulcânico, feldspatóides, olivinas e piroxênios (Sgarbi et al. 2001).

Os uganditos são rochas inequigranulares seriada, fina a média $(0,1-2,5 \mathrm{~mm})$, que apresentam uma mineralogia similar à dos mafuritos, porém com abundancia de leucita e quase ausência de olivina. 


\subsubsection{Lamprofíros}

Lamprofíros são um grupo diversificado de rocha, com características químicas que não se distingue facilmente de outras rochas ígneas normais. Ocorrem geralmente em pequenos volumes, sob a forma de diques, lapólitos, lacólitos, filões ou pequenas intrusões. São rochas alcalinas sub-saturadas em sílica, com teor de $\mathrm{MgO}>3 \%$, tradicionalmente sendo distiguidas através das seguintes características (Le Maitre et al, 2002):

- São porfiríticas, mesocráticas a melanocráticas $\left(M^{\prime}=35-90\right)$, mais raramente ultramáficas $\left(\mathrm{M}^{\prime}>90\right)$;

- Feldspatos e / ou feldspatóides, quando presentes, são restritos a matriz;

- Usualmente contém essencial biotita (ou Fe - flogopita) e / ou anfibólio e algumas vezes clinopiroxênio;

- Alteração hidrotermal de olivina, piroxênio, biotita e plagioclásio, quando presente, é comum;

- Calcita, zeolitas e outros minerais hidrotermais podem aparecer como fases primárias;

- Possuem teores de $\mathrm{K}_{2} \mathrm{O}$ e/ou $\mathrm{Na}_{2} \mathrm{O}, \mathrm{H}_{2} \mathrm{O}, \mathrm{CO}_{2}, \mathrm{~S}, \mathrm{P}_{2} \mathrm{O}_{5}$ e $\mathrm{Ba}$ relativamente altos, quando comparados com outras rochas de composição similar.

O termo lamprofíro ultramáfico (Tappe et al, 2005) é usado como termo coletivo de rochas potássicas sub-saturadas em silica, melanocratícas a ultramáficas, com fenocristais hidratados essenciais. 


\subsection{Proposta de nomenclatura para as rochas que compõem as intrusões estudadas}

A classificação das rochas pertencentes aos clãs dos kamafugitos, kimberlitos, orangeitos e lamproítos é um exercício bastante complexo, não raramente obtendo-se resultados pouco convincentes ou mesmo insatisfatórios. Isto deve-se inteiramente à sobreposição de tantas características petrográficas, mineralógicas, químicas e isotópicas, que elevam tais clãs à categoria de rochas das mais difíceis de identificação. Em verdade, todas essas rochas dispõem-se na região limite entre nomenclaturas diversas. Esta particularidade muitas vezes se reflete diretamente na literatura com a diversidade de nomes atribuídos a rochas de uma mesma ocorrências, principalmente quando baseados em critérios distintos. Mencione-se, como exemplo, a intrusão Pântano, da mesma província (PIAP) e situada a poucos quilômetros de Indaiá, onde foi caracterizada inicialmente como olivina basalto, depois mica peridotito e posteriormente Meyer et al. (1994) mostraram que a composição química dessas rochas é similar a kimberlito, alnöito com baixa alumina e a alguns peridotitos; mais recentemente, Azzone (2002) concluiu que a rocha de Pântano representa um kimberlito hipoabissal megacristalino venulado.

Muitas das incontáveis ocorrências dessa natureza no PIAP acham-se desprovidas de estudos de detalhe ou pobremente definidas, particularmente quando não exibem evidências marcantes de um determinado clã, como por exemplo a presença de diamante, ou então, de uma paragênese mineral típica como k-richterita, priderita, wadeita, e titanato de bário, representando um lamproíto.

Assim, com o objetivo de alcançar uma caracterização petrológica a mais correta possível, buscou-se para a nomenclatura de Indaiá I e Indaiá II a conjunção de feições texturais, modais, mineralógicas e químicas de minerais, denominada por Mitchell (1995) de classificação genética.

\subsubsection{Indaiá I}

A intrusão Indaiá I foi preliminarmente classificada neste trabalho como uma brecha kimberlítica macrocristalina, pertencentes a fácies hipoabissal. A rocha apresenta textura tipicamente inequigranular com populações distintas de olivina (megacristais, macrocristais e matriz) e abundantes xenólitos ultramáficos mantélicos, imersos em uma matriz afanítica contendo olivina, minerais opacos, monticellita, perovskita e clinopiroxênio (diopsídio), além de carbonatos intersticiais, no entanto, outras feições dessas rochas devem ser destacadas no sentido de contribuir para uma nomenclatura a mais correta.

Posto a inexistência dos feldspatóides kalsilita, nefelina e leucita como integrante da assembléia mineral que compõem as rochas de Indaiá I, descartou-se a hipótese de a mesma 
pertencer ao grupo dos kamafugitos. Assim, resta, então, racionalizar com as definições dos membros dos clãs dos kimberlitos, orangeitos e lamproítos.

As olivinas de Indaiá I apresentam uma variação composicional bastante restrita,

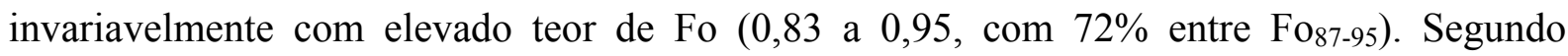
Mitchell (1995), a variação composicional limitada da olivina é característica de kimberlitos e orangeitos. Entretanto, estudos sistemáticos realizados com olivina de kimberlitos e kamafugitos da PIAP (Araujo, 2000), mostram que sua composição não permite uma discriminação eficiente das rochas dos clãs kimberlitos, kamafugitos e nem mesmo dos orangeitos, tendo em vista que os intervalos composicionais são praticamente os mesmos. $\mathrm{O}$ mesmo comportamento pode ser estendido para elementos como $\mathrm{Ca}$, $\mathrm{Ni}$ e $\mathrm{Mn}$.

Monticellita foi observada em quantidade na matriz das rochas de Indaiá I e confirmada por análise semi-quantitativa por microssonda WDS. O mineral é considerado como parte da paragênese da matriz de kimberlitos, estando, no entanto, ausente nos orangeitos. Desse modo, essa característica mineralógica de Indaiá I permite excluir a possibilidade dessas rochas pertencerem ao clan dos orangeitos.

Os raros piroxênios registrados na intrusão são de dois tipos, um diopsídico na matriz e outro do grupo da enstatita - ferrossilita nos macrocristais. O diagrama $\mathrm{Mg}-\mathrm{Ca}-\mathrm{Fe}$ (Figura 35A) mostra os campos de variações composicionais de ortopiroxênios de kimberlitos de várias ocorrências mundiais. Observa-se que os ortopiroxênios de Indaiá I se sobrepõem com os dos campos dos kimberlitos Letseng-la-terae (Lesoto), Monatery I e II (África do Sul) e Sloan - Nix empobrecidos em cromo (EUA), posto os baixos teores de $\mathrm{CaO}(<1,53), \mathrm{A} 12 \mathrm{O} 3$ $(<0,99)$ e $\mathrm{Cr} 2 \mathrm{O} 3(<0,52)$, sugerindo caráter kimberlítico desta rocha.

Os minerais do grupo do espinélio foram registrados na matriz e inclusões de olivina, apresentando uma variação composicional bastante ampla. São representados pelos membros cromita, titanomagnetita-ulvöespinélio $\left(\mathrm{TiO}_{2}\right.$ e $\mathrm{MgO}$ - alto na matriz e baixo na inclusão de olivina) e Cr-espinélio. Os espinélios possuem uma relação $\mathrm{Cr} /(\mathrm{Cr}+\mathrm{Al})$ variando entre 0,42 e $0,86 \mathrm{e} \mathrm{Fe}^{2+} /\left(\mathrm{Fe}^{2+}+\mathrm{Mg}\right)$ entre 0,35 e 0,55, com valores médios de $\mathrm{TiO} 2, \mathrm{MgO}$ e $\mathrm{MnO}$ de 5,61, 12,89 e 0,46 , respectivamente. A Figura 35B mostra os campos definidos para composição de espinélios de kimberlitos, orangeitos e lamproítos. As análises dos espinélios de Indaiá I não se encaixam em nenhuma das tendências composicionais de espinélios de kimberlitos propostas por Mitchell (1995), denotando claramente nova tendência composicional. 


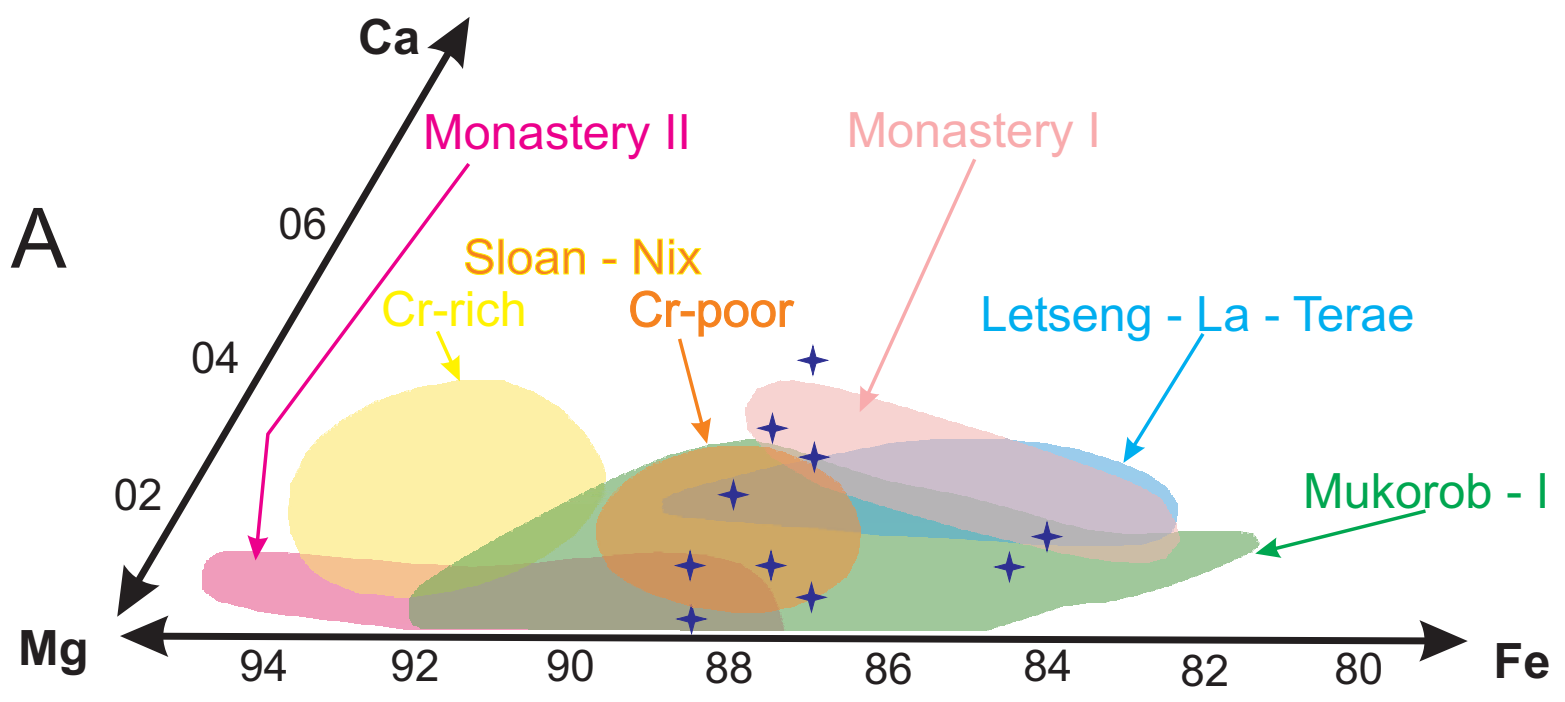

\section{LEGENDA}

+ Ortopiroxênios da intrusão Indaiá I

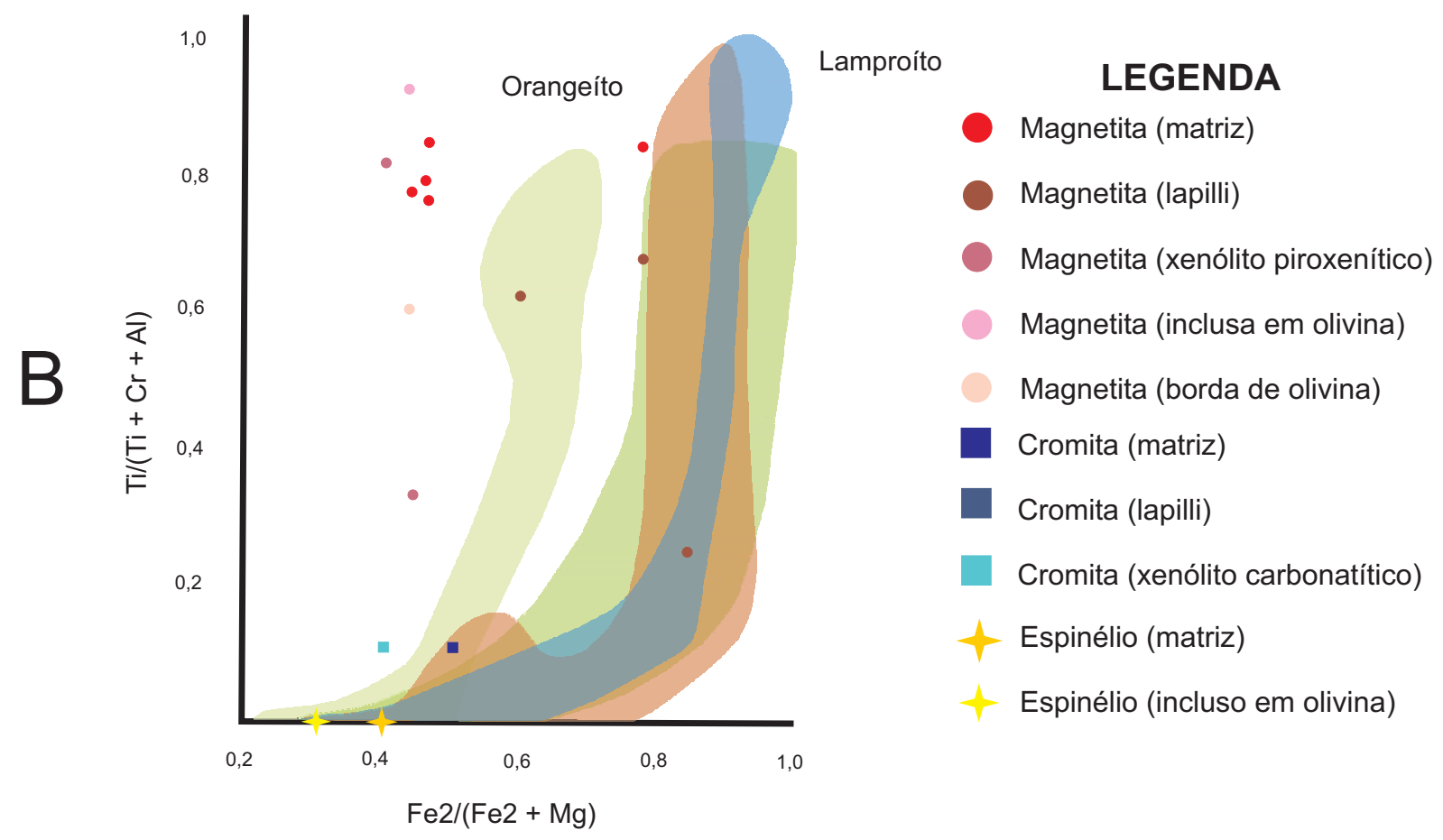

Figura 35. A: Diagrama ternário Mg-Fe-Ca comparando a variação composicional de ortopiroxênios de Indaiá I com os campos composicionais de ortopiroxênios dos kimberlitos Monastery, Sloan - Nix, Letseng-la-terae e Mukorob (adaptado de Mitchell, 1986). B: Trends composicionais de espinélios provenientes de kimberlítos (T1 - trend de ulvoespinélio magnesiano; T2 - trend de titanomagnetita), orangeítos e lamproítos. Modificado de Mitchell, 1995. 
Ilmenita magnesiana é um mineral abundante na intrusão de Indaiá I e possui uma variação composicional nas populações de macrocristais, de inclusão nas olivinas e na matriz que sobrepõe a de ilmenitas de ocorrências kimberlíticas mundiais (Mitchell, 1986). Ela é caracterizada principalmente pelos componentes ilmenita-geikielita ( $>70 \%$ mol)-hematita, com teores de $\mathrm{MgO}$ e $\mathrm{Cr}_{2} \mathrm{O}_{3}$ respectivamente nos intervalos 8,29-11,95\% e 1,34-5,06\% nos macrocristais, $7,24-18,32 \%$ e $1,05-1,72 \%$ na matriz e $10,66-12,12 \%$ e $1,19-3,25 \%$ nas inclusões. Destaca-se que os teores de $\mathrm{MgO}$ e $\mathrm{Cr}_{2} \mathrm{O}_{3}$ dos macrocristais sobrepõem em grande parte aos observados em ilmenitas do xenólito mantélico de piroxênio $(10,00-10,30 \%$ e 1,132,30\%), sendo nos dois casos inferiores aos determinados no xenólito de dunito.

Tais características, texturais e químicas das ilmenitas estudadas, diferem das descritas na literatura para ilmenitas dos lamproítos e orangeitos (Mitchell, 1995). Nos lamproítos, ela apresenta teores de $\mathrm{MgO}(<7,5 \%)$ muito aquém dos observados em kimberlitos, com $\mathrm{Cr}_{2} \mathrm{O}_{3} \mathrm{e}$ $\mathrm{Al}_{2} \mathrm{O}_{3}$ frequentemente inferior a $0,5 \%$. Já nos orangeitos, a ilmenita da matriz apresenta teores muito baixos de $\mathrm{MgO}(<2,98 \%)$ e $\mathrm{Cr}_{2} \mathrm{O}_{3}(<0,6 \%)$, e elevados de $\mathrm{MnO}(4,4$ a $18,3 \%)$. Assim sendo, as ilmenitas estudadas são comparáveis em tudo às de rochas kimberlíticas, descartando, portanto, a possibilidade de Indaiá I pertencer ao grupo dos lamproítos ou orangeitos. Alguns diagramas com os campos composicionais de ilmenitas de kimberlitos de várias ocorrências do mundo também corroboram a filiação das ilmenitas estudadas com rochas kimberlíticas. No diagrama $\mathrm{TiO}_{2}$ vs. $\mathrm{MgO}$ e $\mathrm{Cr}_{2} \mathrm{O}_{3}$ vs. $\mathrm{MgO}$ (Figura 36, Wyatt et al. 2004) a composição coincide com o campo de ilmenitas de kimberlitos não cratônicos do Grupo I da África do Sul e Namíbia. A mesma afinidade pode ser observada nos sistemas geikielita - ilmenita - hematita e geikielita - ilmenita - pirofanita (Figuras 37 e 38 respectivamente), onde mostram os campos de ilmenitas de rochas kimberlíticas, basaltos alcalinos, alnoítos e outros (Mitchell, 1986). 


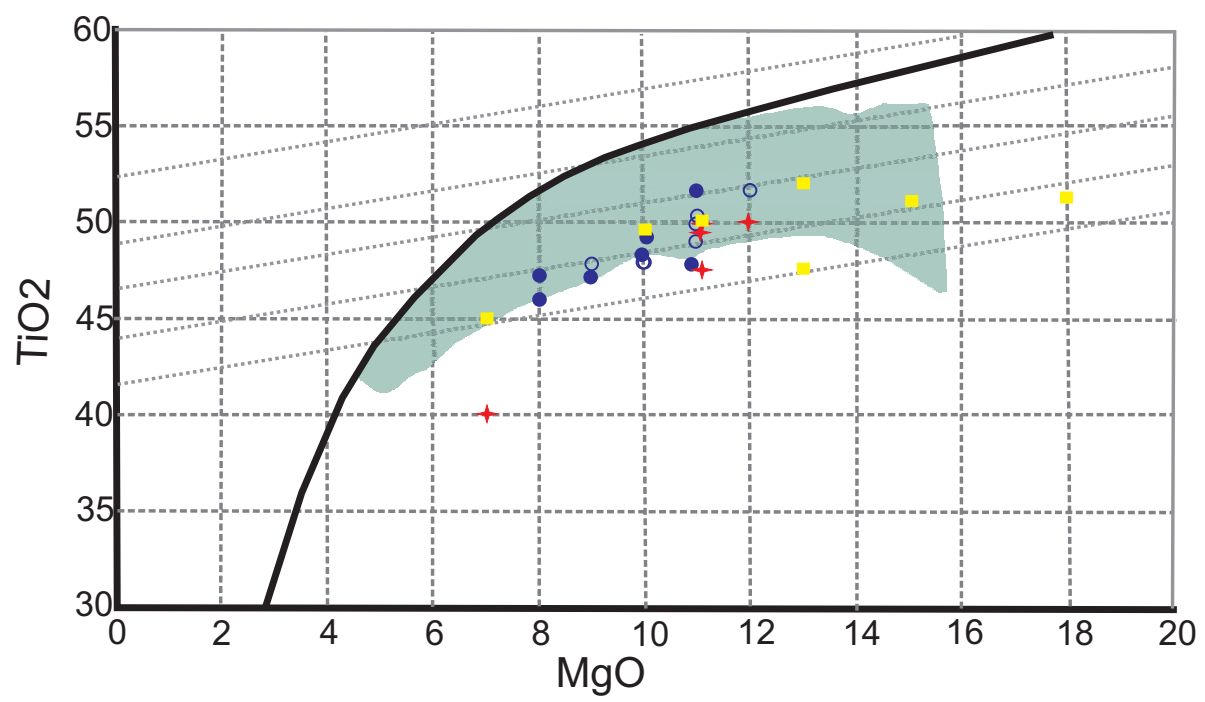

A

\section{LEGENDA}

Fenocristais - borda

Fenocristais - núcleo

$\uparrow$ Inclusos em olivina

Matriz

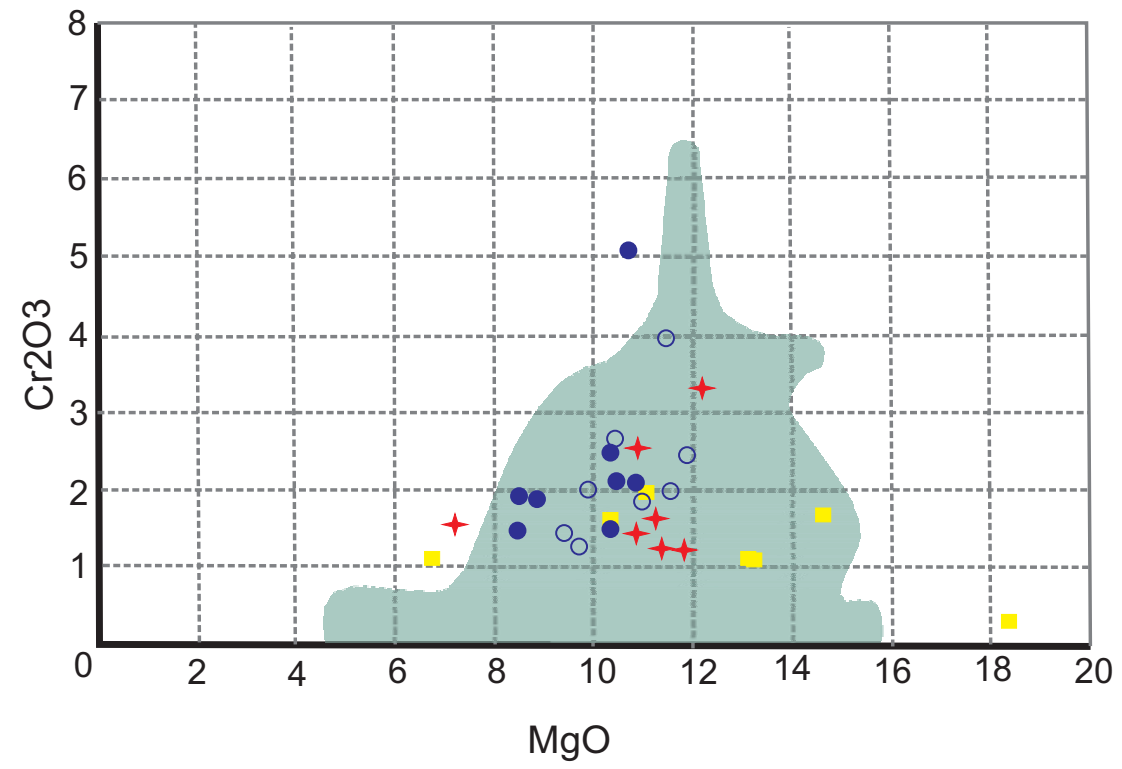

Figura 36. Composição de ilmenitas da intrusão Indaiá I (\% em peso) nos diagramas $\mathrm{TiO} 2$ vs $\mathrm{MgO}(\mathrm{A})$ e $\mathrm{Cr} 2 \mathrm{O} 3$ vs $\mathrm{MgO}$ (B), com os campos composicionais de ilmenitas de kimberlitos não cratônicos do Grupo I (África do Sul/Namibia). Modificado de Wyatt, 2004. 


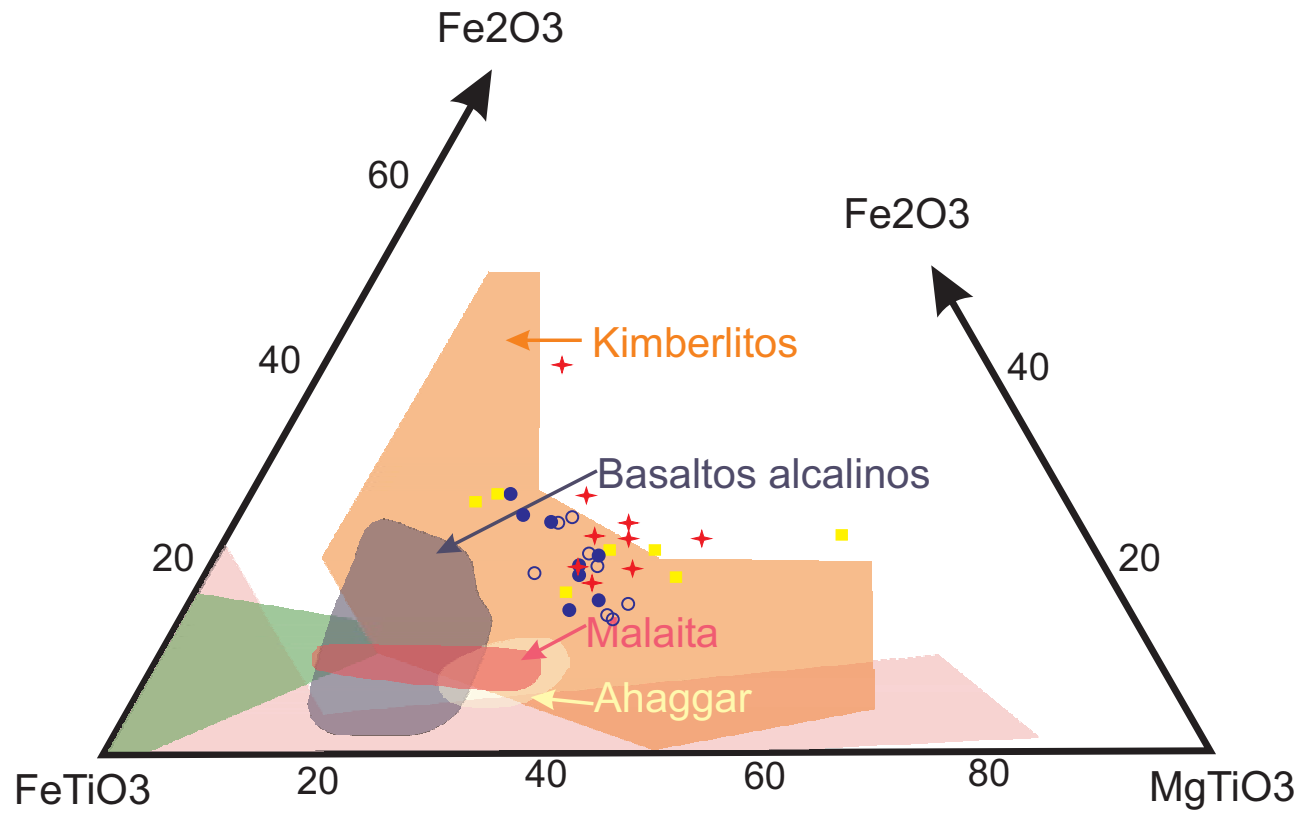

\section{LEGENDA}

Fenocristais - borda

Fenocristais - núcleo

$\gamma$ Inclusos em olivina

Matriz

Figura 37. Composição de ilmenitas da intrusão Indaiá I no sistema MgTiO3-FeTiO3-Fe2O3, comparados com o campo composicional de ilmenitas kimberlíticas, basaltos alcalinos, alnoitos Malaita (Lesoto) e basanitos Ahaggar (sul da Argelia). Campos A e B, representam, respectivamente, composições de ilmenitas de granitos e carbonatitos. (Modificado de Mitchell, 1986). 


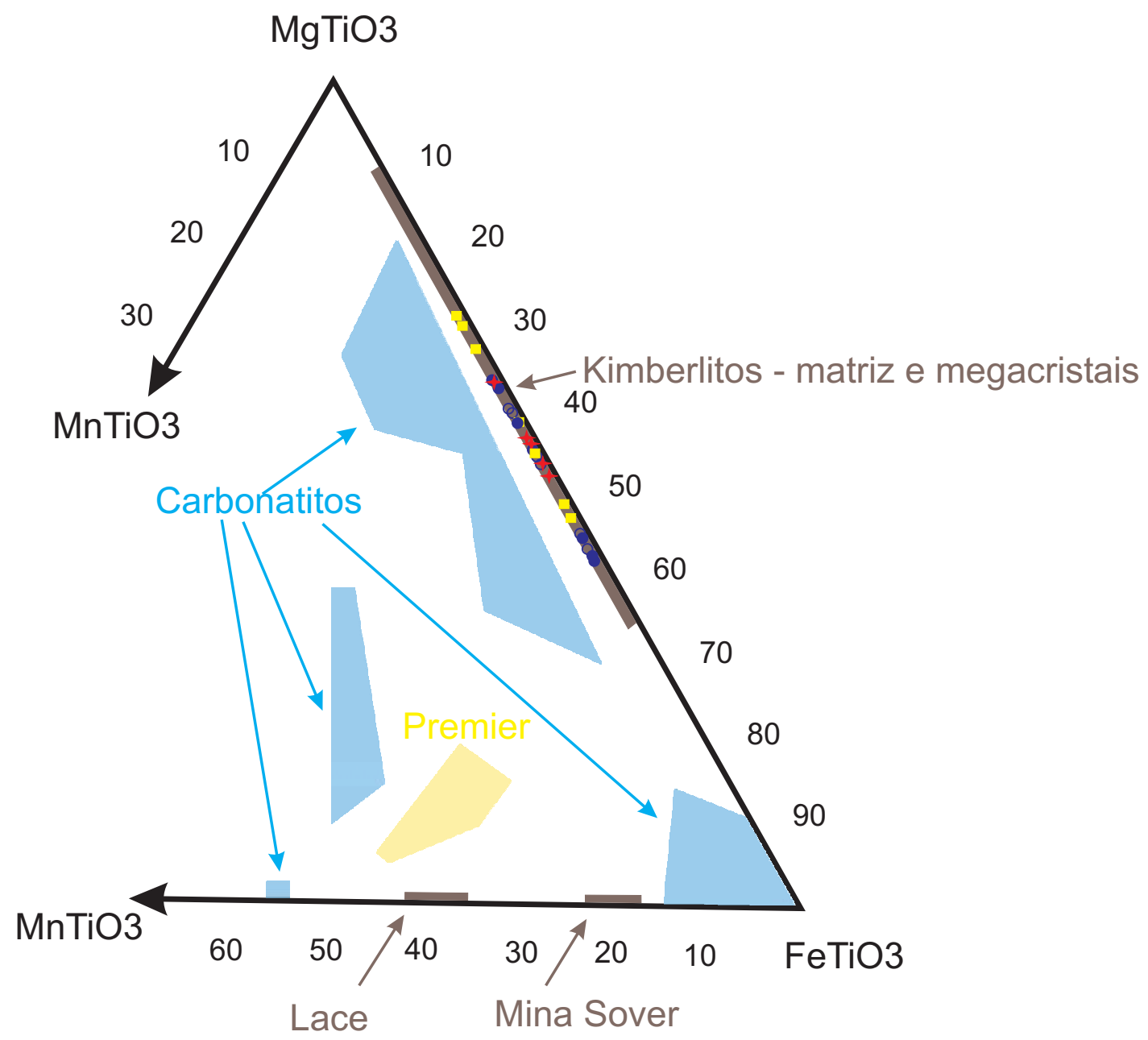

\section{LEGENDA}

Fenocristais - borda

Fenocristais - núcleo

$\gamma$ Inclusos em olivina

Matriz

Figura 38. Ilmenitas da intrusão Indaiá I locadas no sistema ternário geikielita - ilmenita-pirofanita, juntamente com os campos composicionais de ilmenitas dos orangeítos Lace e Sover Miner, carbonatitos e kimberlitos (adaptado de Mitchell, 1995). 
A perovskita é também um mineral que apresenta características químicas discriminativas que podem auxiliar na distinção entre kimberlitos, orangeitos, lamproítos e kamafugitos. Segundo Mitchell (1995), a perovskita de kimberlitos compõe-se essencialmente da molecula $\mathrm{CaTiO}_{3}$ (end-member perovskita $>90 \%$ ), enquanto nos orangeitos e lamproítos ela é mais enriquecida principalmente nos componentes loparita $\left(\mathrm{NaCeTi}_{2} \mathrm{O}_{6}\right)$ e tausonita $\left(\mathrm{Sr}_{2} \mathrm{Ti}_{2} \mathrm{O}_{6}\right)$. No diagrama $\mathrm{CaTiO}_{3}-\mathrm{NaCeTi}_{2} \mathrm{O}_{6}-\mathrm{NaNbO}_{3}$-(Figura 39), todas as análises de perovskitas de Indaiá I locam-se no campo definido para os kimberlitos $\left(\mathrm{CaTiO}_{3}>90 \% \mathrm{~mol}\right)$, descartando assim um caráter orangeítico ou lamproítico.

Posto o discutido retro sugerimos classificar a rocha da intrusão Indaiá I como kimberlito pertencente ao Grupo I (Le Maitre et al., 2001), confirmando os estudos iniciais propostos por Meyer et al. (1991).

\subsubsection{Intrusão II}

Segundo Meyer et al. 1991, a intrusão Indaiá II contém uma associação de minerais similar à Indaiá I (olivina, Mg-ilmenita, piroxênio, perovskita e espinélio), apresentando, contudo, uma matriz com vidro e nefelina, componentes ausentes na intrusão I. Nesse estudo, ainda que preliminar, esses autores concluíram que a intrusão Indaiá II é quimicamente diferente de qualquer kimberlito conhecido, conquanto apresente uma assinatura isotópica similar à de Indaiá I. As análises químicas dessas rochas foram comparadas aos uganditos de Katwe, do escudo vulcânico de Toro-Ankole, Uganda.

No presente trabalho foram estudadas vinte e cinco seções delgadas de múltiplas amostras, coletadas em pontos distintos representando todo o corpo intrusivo e cortadas em posições diversas, tendo como alvo a rocha em si e diferentes materiais tais como fenocristais e xenólitos. As informações obtidas na petrografia (item 4), no seu todo confirmadas com auxílio da microssonda eletrônica (EDS e WDS), mostram que a intrusão Indaiá II compõe-se de uma matriz complexa constituída essencialmente de clinopiroxênio diopsídico esverdeado, minerais opacos, espinélio avermelhado, perovskita e olivina, além de raro vidro intersticial devidrificado. Imersos na matriz ocorrem macrocristais e fenocristais olivina, e microfenocristais de minerais opacos, espinélio avermelhados e perovskita. Ressalta-se que em nenhuma lâmina foi observado, na matriz ou nos microfenocristais e cristais maiores cogenéticos, a presença de feldspatóides, seja nefelina, kalsilita ou leucita. Foram registradas também uma fase pós-magmática, representada por microvenulações dispersas na matriz e preenchidas distintamente por materiais diversos, tais como agregado de mineral incolor a amarelado, vidro parcialmente devitrificado e mineral não identificado (scherbakovita?). 


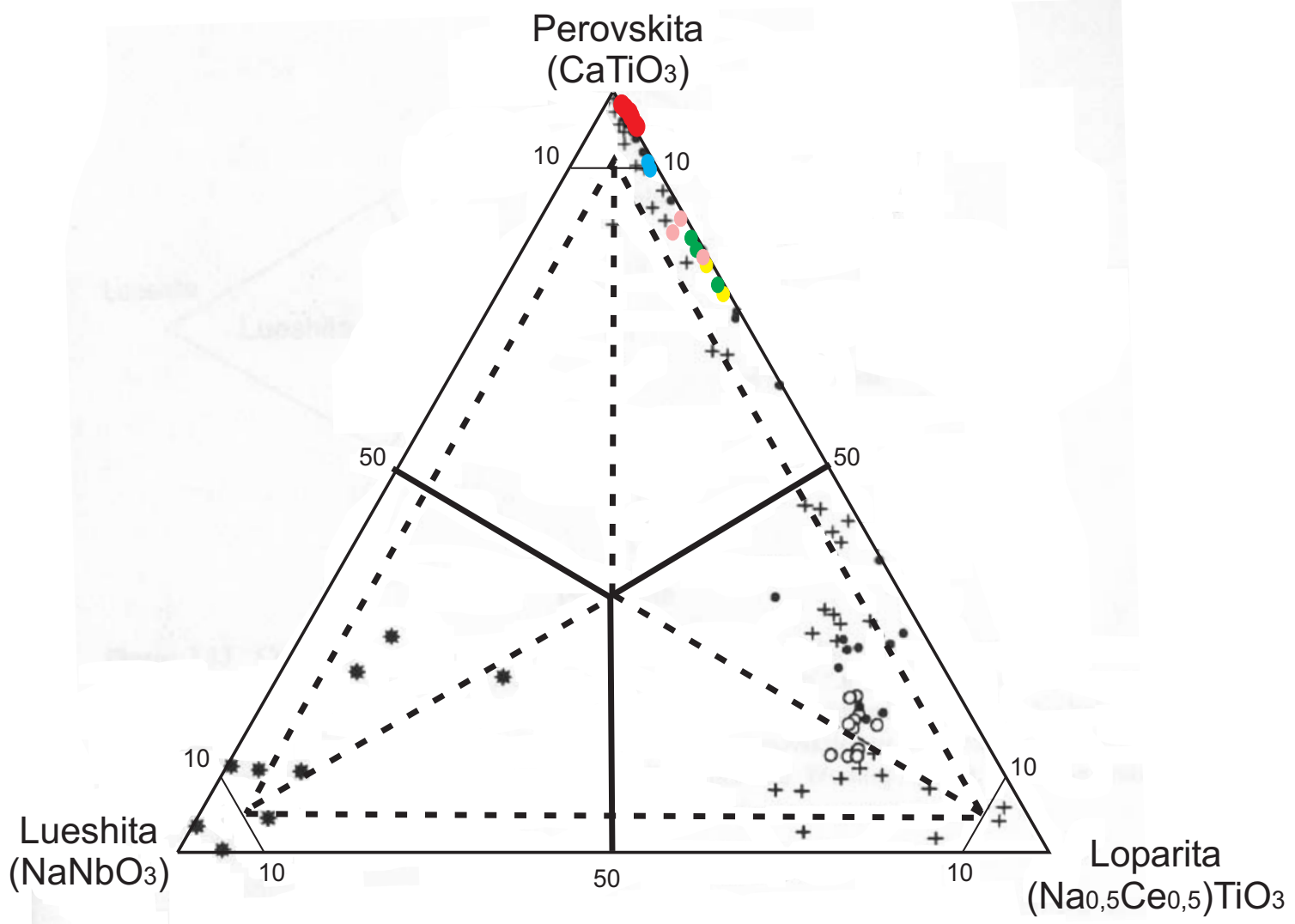

\section{LEGENDA}

- Intrusão Indaiá I

- Afrikander

O Lovozero

+ Schryburt Lake

Sover Mine

Sover North

- Besterskraal

- Bellsbank

Figura 39. Composição de perovskitas (\% mol.) de Indaiá I locadas no sistema ternário perovskita lueshita - loparita. (Modificado de Mitchell, 1995). 
Além disso, observou-se que a rocha contém xenólitos em abundância ( $24 \%$ em volume), sendo descritos macro e microscopicamente em todas as amostras. Os xenólitos são representados por diversos litotipos, tais como duníticos, carbonatíticos, nefeliníticos, microcristalinos (diopsídio, sanidina e opacos), além de outros com mineralogia similar à rocha hospedeira. Dentre estas variedades, destaca-se o xenólito nefelinítico pela sua mineralogia distintiva, possuindo uma paragênese rica em nefelina e kalsilita. Mencione-se que muitos destes xenólitos apresentam formas estiradas, às vezes parcialmente interagidos com a rocha hospedeira, sugerindo a existência de algum grau de hibridação, ainda que pequeno.

As observações acima são contribuições fundamentais para o estudo petrológico dessas rochas. Elas permitem, por exemplo, concluir que a intrusão Indaiá II tem uma mineralogia totalmente desprovida de feldspatóide. Os feldspatóides (nefelina e kalsilita) existentes foram registrados tão somente nos xenólitos com bordas bastante irregulares e/ou estirados, conforme pode ser visto claramente nas Figuras 40 A e B.

Isto posto, tais características petrográficas suportam uma afinidade magmática relacionada com um dos clãs, qual seja, kimberlito, orangeito ou lamproíto, excluindo a possibilidade de Indaiá II (isento de feldspatóide) pertencer ao clã dos kamafugitos. Nesse sentido, a conjunção das feições químicas peculiares dos principais minerais poderá oferecer subsídios para um melhor entendimento da filiação petrológica dessas rochas, contribuindo para uma nomenclatura mais aceitável.

A olivina das rochas da intrusão Indaiá II apresenta o mesmo intervalo de variação composicional $\left(\mathrm{Mg} / \mathrm{Mg}+\mathrm{Fe}^{2+} 0,83\right.$ a 0,$93 ; \sim 94 \%$ entre $\left.\mathrm{Fo}_{86-93}\right)$ da intrusão Indaiá I, com baixos teores de $\mathrm{CaO}(<0,32 \%), \mathrm{MnO}(<0,27 \%), \mathrm{Cr}_{2} \mathrm{O}_{3}(<0,05 \%)$ e $\mathrm{NiO}(<0,21 \%)$. A variação composicional restrita (Mitchell, 1995) e os conteúdos baixos de $\mathrm{Ca}, \mathrm{Cr}$ e $\mathrm{Ni}$ (Araujo, 2001), são indícios que favorecem uma correspondência com kimberlitos.

Os clinopiroxênios correspondem a um diopsídio de composição bastante restrita $\left(\mathrm{En}_{39,73} \mathrm{Fs}_{10,23} \mathrm{Wo}_{47,97}\right)$, embora com pequenas diferenças entre os grãos da matriz e de microfenocristal. Neste último, ele é comparável aos diopsídios do xenólito dunítico. $\mathrm{O}$ diagrama apresentado a seguir (Figura 41) mostra os campos de variação composicional dos clinopiroxênios de Indaiá II, coincidindo com os campos de lamproítos e orangeítos. 


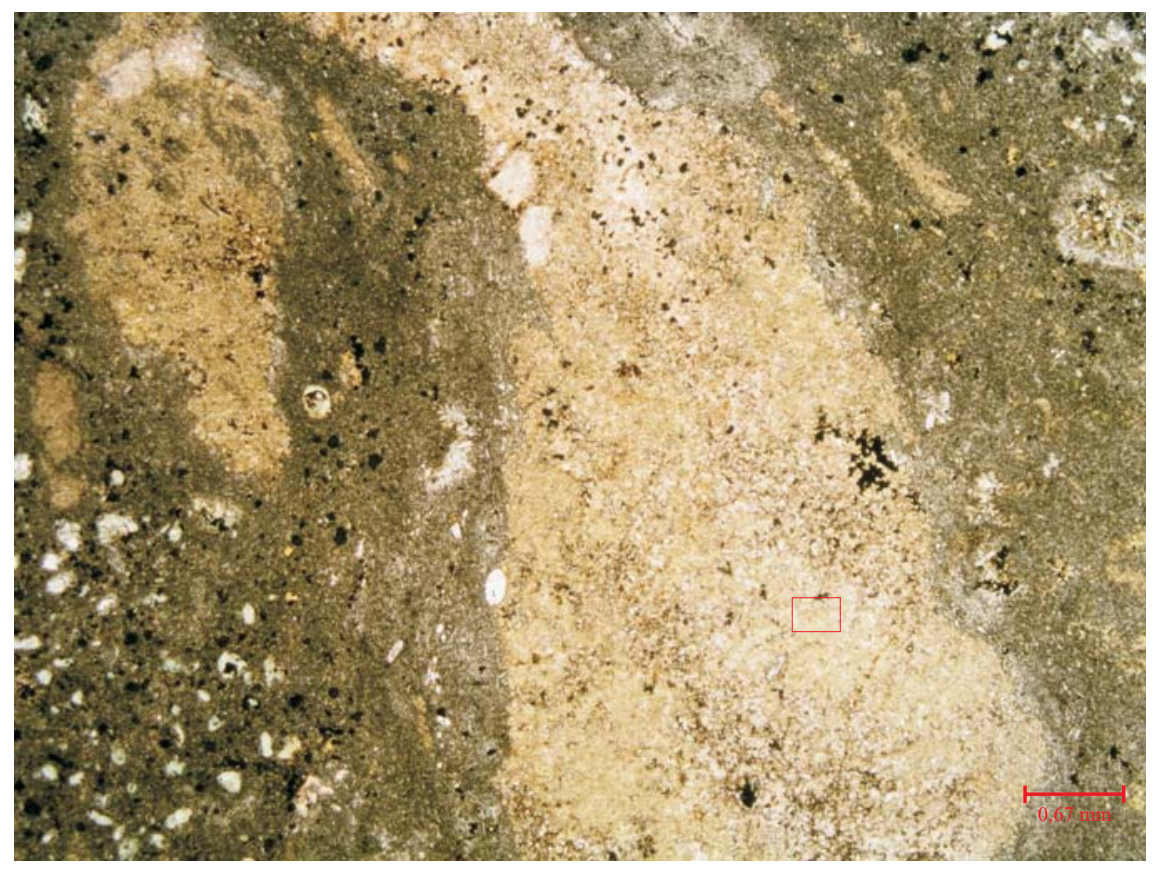

Figura 40A. Fotomicrografia de rochas da intrusão Indaiá II. Xenólito nefelinítico, com bordas irregulares e parcialmente estirado, fixado em matriz sem evidente orientação de fluxo. Polarizador descruzado. Lâmina IN 24E.

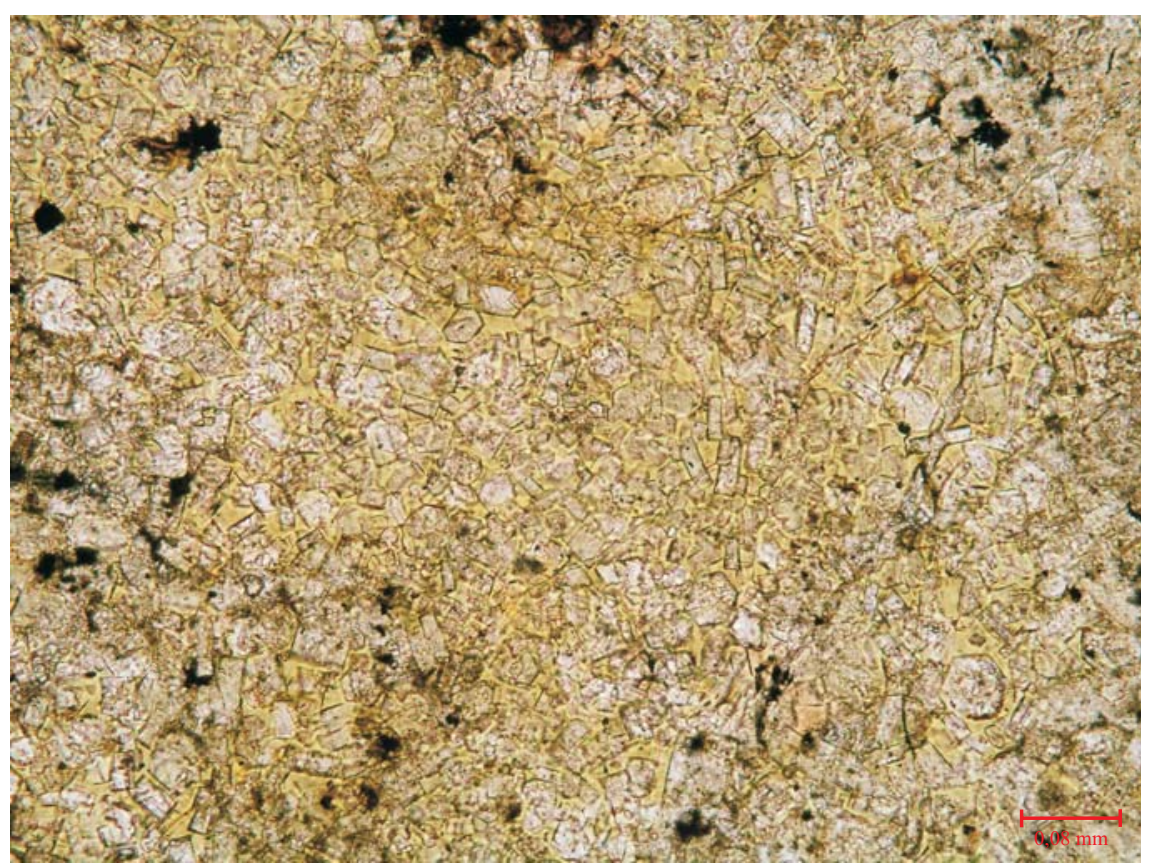

Figura 40B. Fotomicrografia de rochas da intrusão Indaiá II. Detalhe da estrutura demarcada em vermelho da Figura 40A, no xenólito nefelinítico, destacando os cristais de nefelina - kalsilita presentes no interior dos xenólitos. Polarizador descruzado. Lâmina IN 24E. 


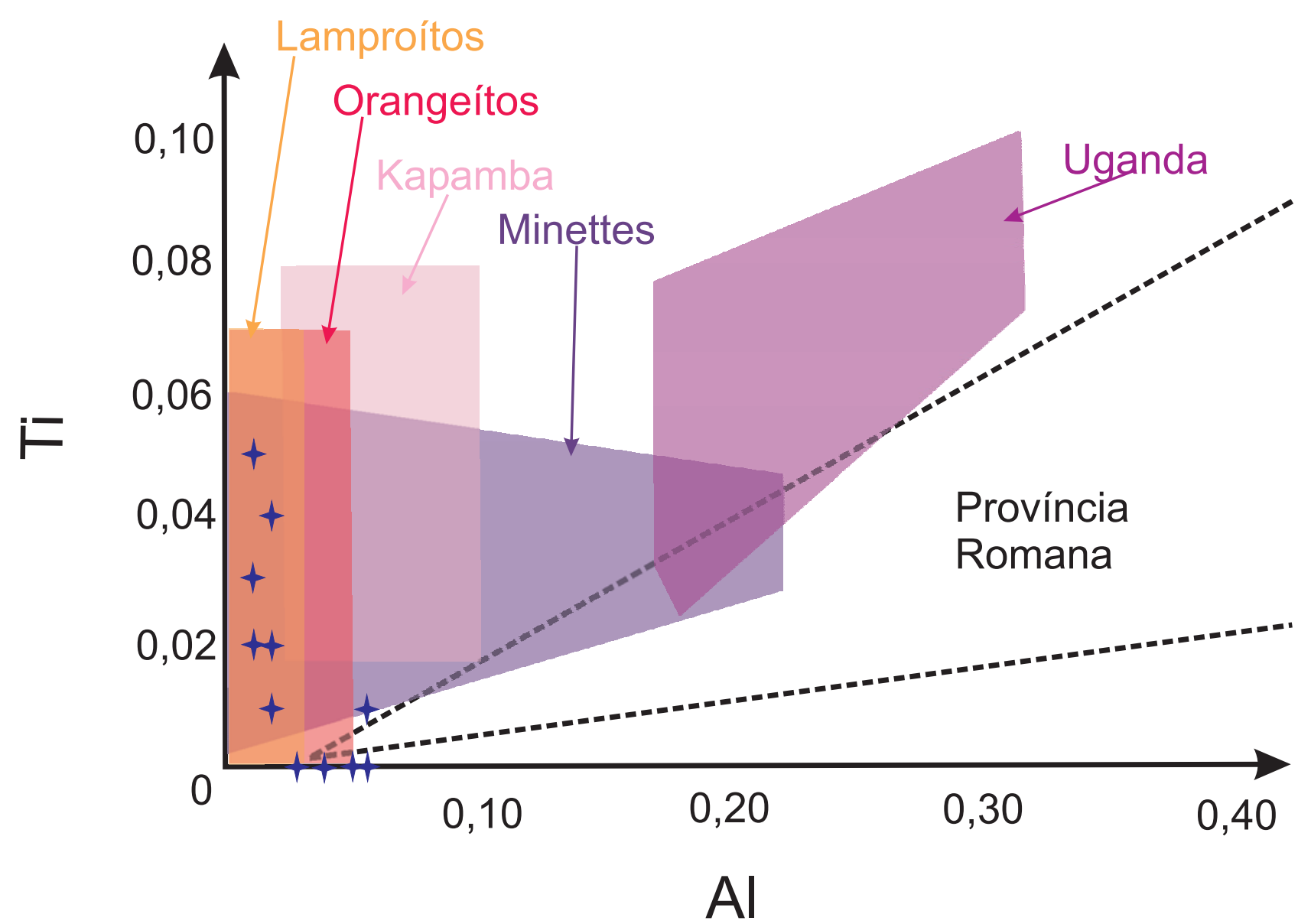

\section{LEGENDA \\ † Intrusão II}

Figura 41. Clinopiroxênios da intrusão Indaiá II locados no diagrama diagrama Al vs Ti e comparados com os campos composicionais de orangeítos e lamproítos, lamproíto Kapamba (Índia), minettes, kamafugitos de Uganda e lavas da Província Romana. (Modificado de Mitchell, 1995). 
Os espinélios de Indaiá II analisados são representados por cromita e série da magnetita

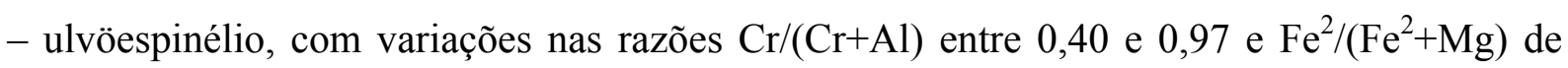
0,41 a 0,84 . Na Figura 42, observa-se que os dados obtidos coincidem com os campos de espinélio de kimberlitos do trend 2 e de orangeítos, estabelecidos por Mitchell (1995).

A presença de ilmenita magnesiana na matriz das rochas intrusivas de Indaiá II é uma feição mineralógica relevante para a sua classificação petrológica, tendo em vista que ilmenitas não são minerais distintivos de lamproítos $(\mathrm{MgO}<7,5 \%)$ e tampouco dos kamafugitos. Assim, essa feição contribui para descartar a hipótese de Indaiá II pertencer ao clã dos kamafugitos como também dos lamproítos. Por outro lado, os teores elevados de $\mathrm{MgO}$ $(\sim 13 \%)$ e $\mathrm{Cr}_{2} \mathrm{O}_{3}(\sim 1,16 \%)$, e baixos de $\mathrm{MnO}(0,64 \%)$ das ilmenitas estudadas afastam-se muito das características de ilmenitas de orangeitos, sendo marcadas em grande parte pelos componentes moleculares geikielita $(\sim 42 \%)$, ilmenita $(39 \%)$ e proporções menores de hematita (17\%). Essas características são comparáveis a ilmenitas de kimberlitos e podem ser melhor visualizados em diagramas com os campos composicionais de ilmenitas de kimberlitos de várias ocorrências do mundo. No diagrama $\mathrm{TiO}_{2}$ vs. $\mathrm{MgO}$ e $\mathrm{Cr}_{2} \mathrm{O}_{3}$ vs. $\mathrm{MgO}$ (Figura 43, Wyatt et al., 2004), as análises das ilmenitas de Indaiá II caem no campo de ilmenitas de kimberlitos não cratônicos do Grupo I da África do Sul e Namíbia, enquanto que no sistema sistema ilmenita - hematita - geikielita (Figura 44), elas ocupam o campo de ilmenitas dos kimberlitos. Já no sistema pirofanita - geikielita - ilmenita (Figura 45), as ilmenitas de Indaiá II são locadas dentro do campo de variação composicional de ilmenitas de matriz e de megacristais de kimberlitos (Mitchell, 1995).

As perovskitas de Indaiá II também apresentaram uma variação composicional com inteiro predomínio do componente perovskita (end-member perovskita, $\mathrm{CaTiO}_{3}$ de 90,08 a $93,70 \% \mathrm{~mol})$ e proporções desprezíveis $(<9,50 \% \mathrm{~mol})$ de loparita e latrappita. Assim, os conteúdos altos de Ti e baixos de elementos terras raras e $\mathrm{Sr}$ das perovskitas estudadas são características comparáveis às de perovskitas de kimberlitos e distintas de perovskitas de orangeitos e lamproítos, conforme mostra o diagrama $\mathrm{CaTiO}_{3}-\mathrm{NaCeTi}_{2} \mathrm{O}_{6}-\mathrm{NaNbO}_{3}$ (Figura 46), onde todas as análises de perovskitas de Indaiá II locam-se no campo definido para os kimberlitos $\left(\mathrm{CaTiO}_{3}>90 \% \mathrm{~mol}\right)$.

Pelo exposto e discutido acima, sugere-se, também, classificar as rochas da intrusão Indaiá II como kimberlito pertencente ao Grupo I (Le Maitre et al., 2001), contrariando assim os estudos iniciais propostos por Meyer et al. (1991). 


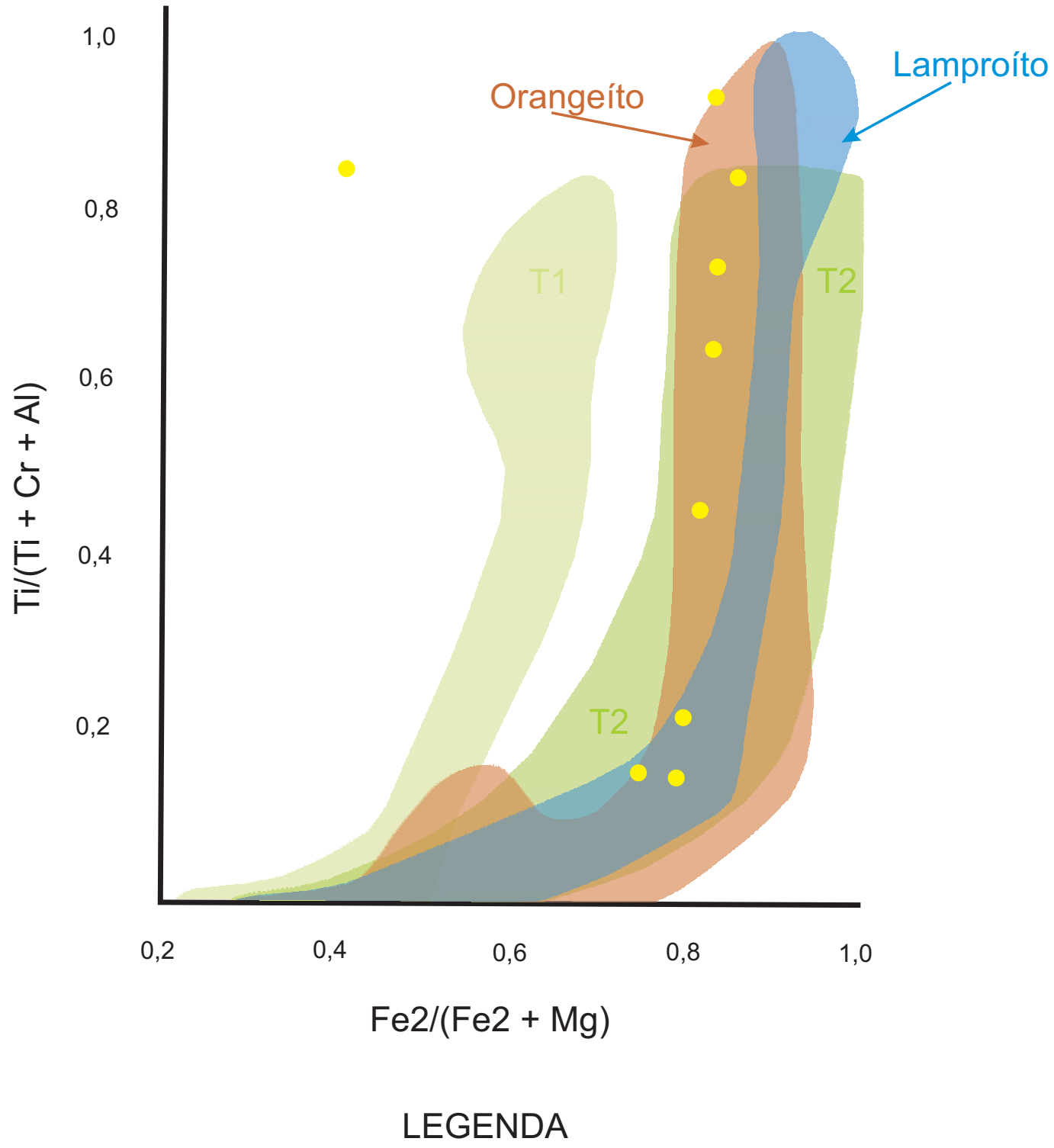

Espinélios da intrusão Indaiá II

Figura 42. Espinélios da intrusão Indaiá II locados em trends composicionais de kimberlítos (T1 trend ulvoespinélio magnesiano; T2 - trend titanomagnetita), orangeítos e lamproítos. Modificado de Mitchell 1995. 


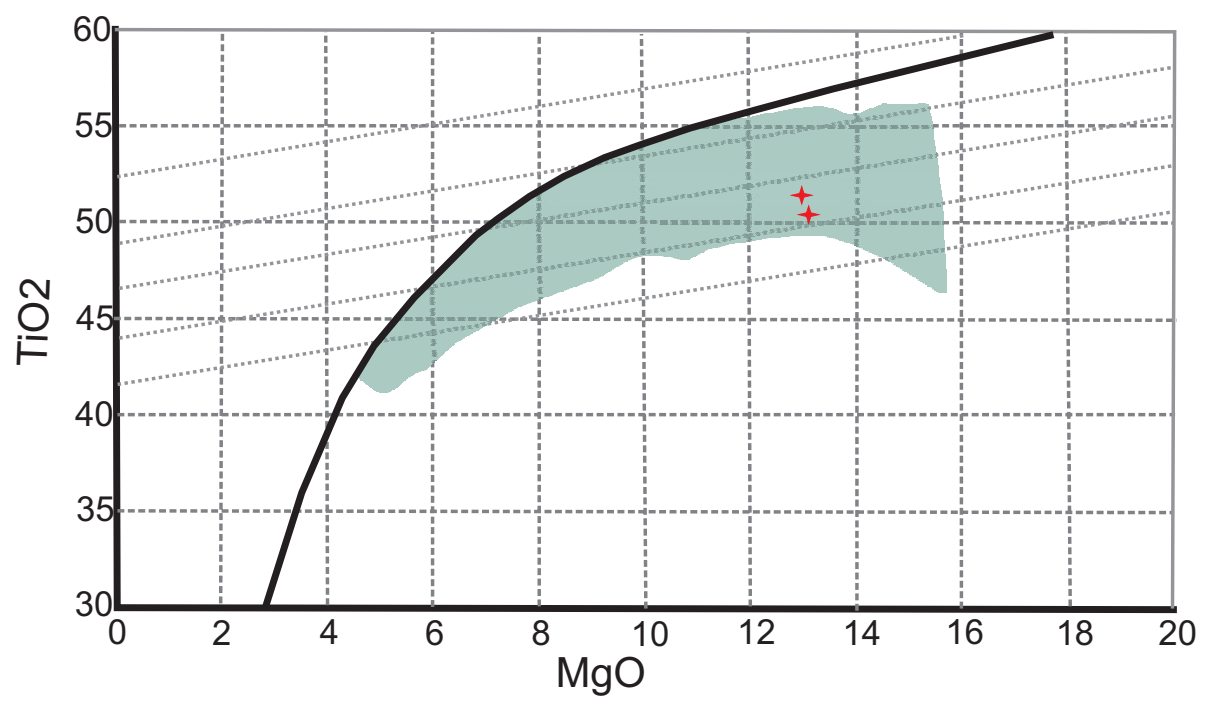

A

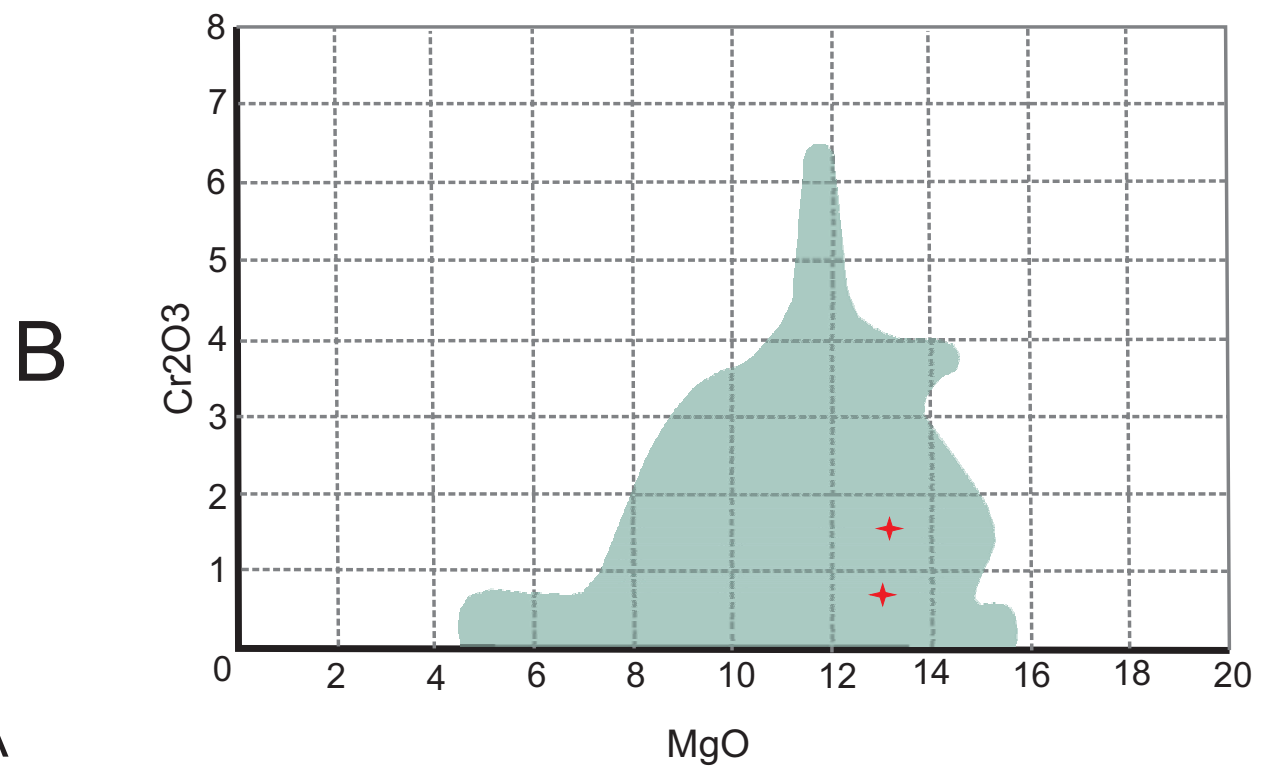

\section{LEGENDA}

Intrusão II

Figura 43. Composição de ilmenitas da intrusão Indaiá II (\% em peso) nos diagramas TiO2 vs MgO (A) e $\mathrm{Cr} 2 \mathrm{O} 3$ vs $\mathrm{MgO}$ (B), com os campos composicionais de ilmenitas de kimberlitos não cratônicos do Grupo I (África do Sul/Namibia). Modificado de Wyatt, 2004. 


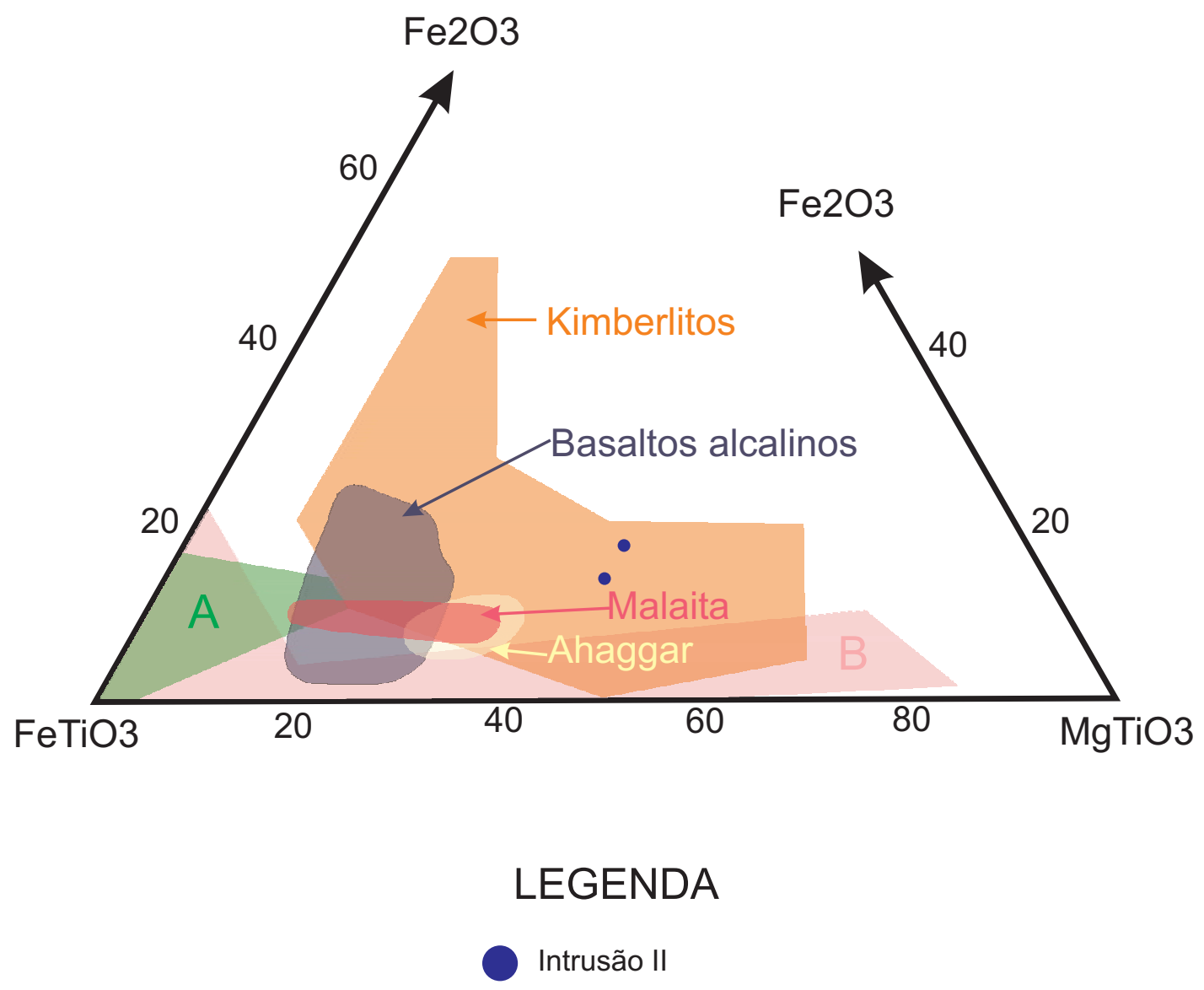

Figura 44. Composição de ilmenitas da intrusão Indaiá II no sistema MgTiO3-FeTiO3-Fe2O3, comparados com o campo composicional de ilmenitas kimberlíticas, basaltos alcalinos, alnoitos Malaita (Lesoto) e basanitos Ahaggar(sul da Argelia). Campos A e B, representam, respectivamente, composições de ilmenitas de granitos e carbonatitos. (Modificado de Mitchell, 1986). 


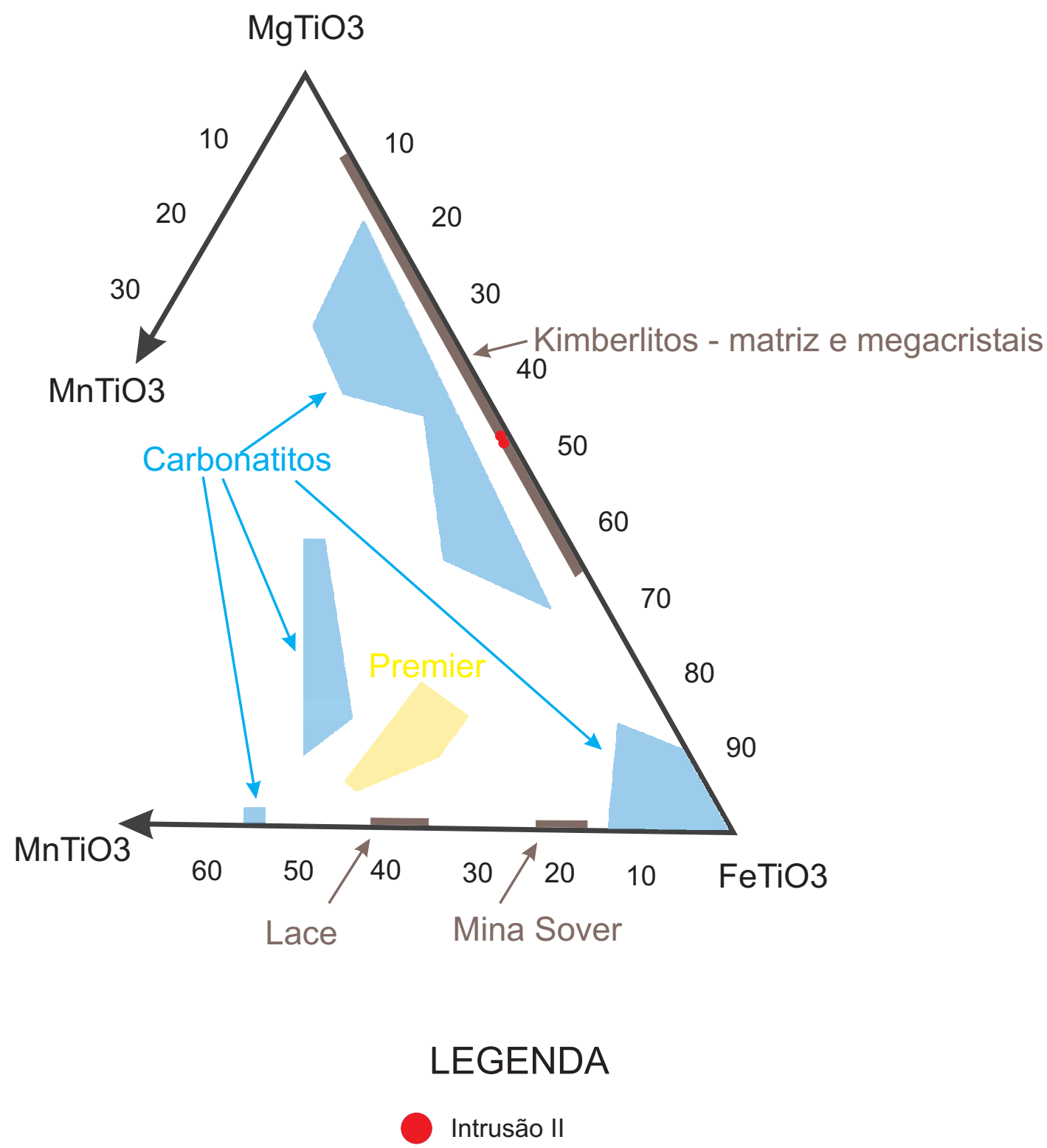

Figura 45. Ilmenitas da intrusão Indaiá II locadas no sistema ternário geikielita - ilmenita-pirofanita, juntamente com os campos composicionais de ilmenitas dos orangeítos Lace e Sover Miner, carbonatitos e kimberlitos (adaptado de Mitchell, 1995). 


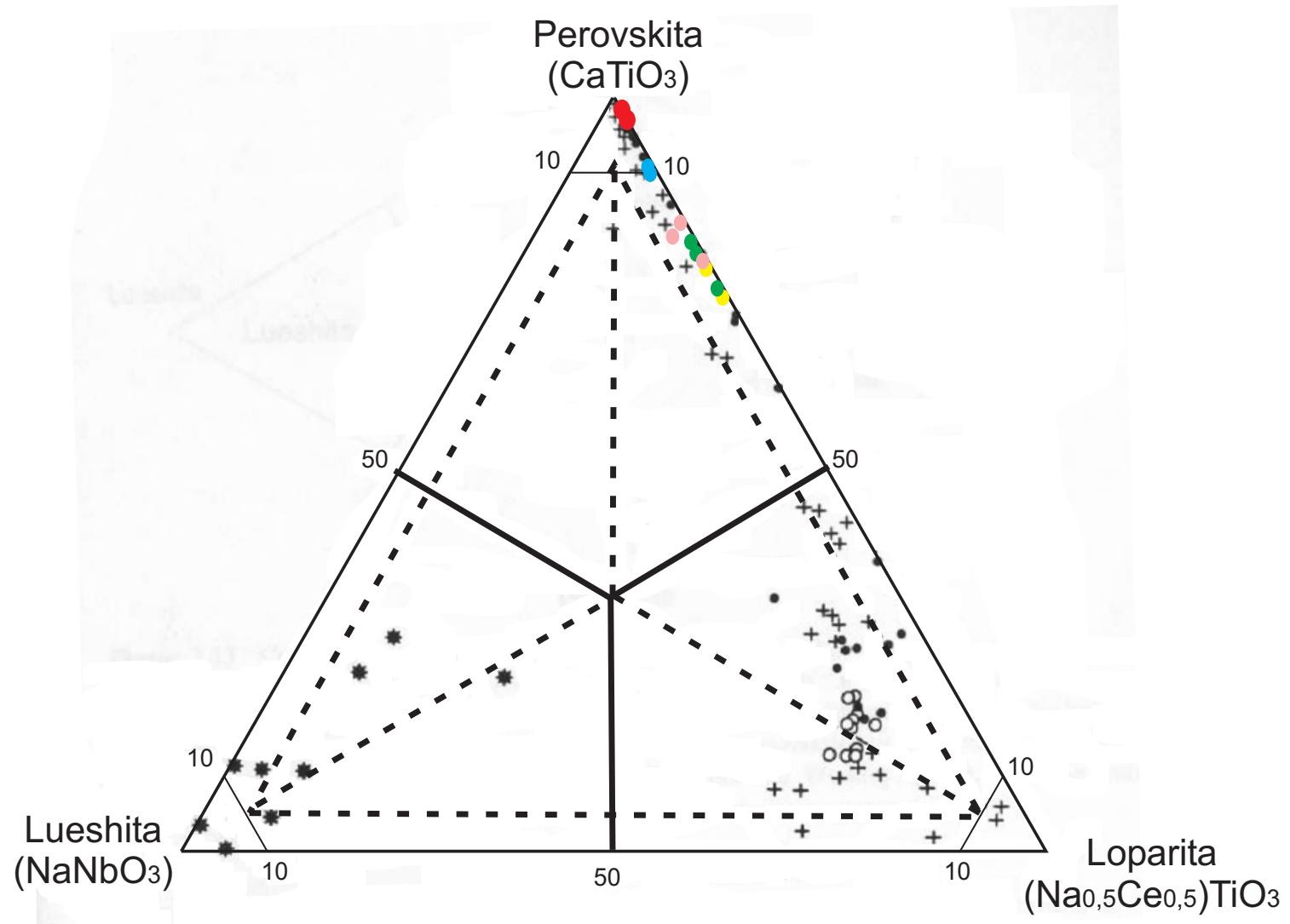

LEGENDA

- Intrusão Indaiá II

- Afrikander

O Lovozero

+ Schryburt Lake

- Sover Mine

Sover North

- Besterskraal

- Bellsbank

Figura 46. Composição de perovskitas (\% mol.) de Indaiá II locadas no sistema ternário perovskita lueshita - loparita. (Modificado de Mitchell, 1995). 


\section{Considerações sobre potencial econômico e região fonte das intrusões Indaiá - I e II}

$\mathrm{Na}$ Província Ígnea do Alto Paranaíba, com seus mais de 300 corpos de rochas ultrabásicas potássica-ultrapotássica de afinidades kimberlítica, kamafugítica e lamproítica mapeados por empresas de prospecção, não apresentam concentrações econômicas de diamantes (Bizzi et al., 1994). Estas informações carecem de total credibilidade, posto que envolvem um dos mercados mais restritos e rentáveis dos mundo. As corporações privadas que desenvolvem prospecções, em sua grande maioria restringem ou não divulgam o conhecimento obtido à comunidade científica. Haja visto as recentes notícias divulgadas, após ao menos meio século de silêncio, sobre vários corpos kimberlíticos portadores de concentrações econômicas de diamantes, alguns já preparados por empresas de mineração para exploração em escala comercial. Cite-se como exemplo, o kimberlito "Canastra" (MG), onde será a primeira exploração de diamante no Brasil, em depósito primário.

A classificação das intrusões Indaiá I e Indaiá II na categoria dos kimberlitos tipo I, rochas classicamente portadoras de diamantes, inevitavelmente induz à especulação sobre a possibilidade destes preciosos xenocristais (Mitchell, 1995) se fazerem presentes.

Kimberlitos mineralizados com altos teores de diamantes são encontrados em áreas cratônicas estáveis e cinturões móveis. Nesse mesmo contexto de ambiente geotectônico, as intrusões Indaiá I e II foram colocadas na faixa móvel Brasília. Contudo, o fato de um kimberlito alojar-se num ambiente adequado e potencialmente favorável para conter diamantes não garante a economicidade da rocha, fazendo-se necessário uma análise cuidadosa de suíte de minerais pesados, tais como granadas (piropo), ilmenitas magnesianas, diopsídios e espinélios cromíferos, os principais indicadores de kimberlitos mineralizados.

Os cristais de ilmenita magnesiana das intrusões Indaiá I e II mostraram similariedades com ilmenitas kimberlíticas típicas (Haggerty, 1975 e 1976; Dawson, 1980), posto que apresentaram variações nos teores de $\mathrm{Cr}_{2} \mathrm{O}_{3}$ entre 1,1 e 2,5 \% e de $\mathrm{MgO}$ entre 6,6 e 13,5\%. Ao se lançar os dados obtidos com as ilmenita estudadas, em diagramas de variação $\mathrm{MgO}$ vs $\mathrm{Cr}_{2} \mathrm{O}_{3}$ (Figura 47), observa-se uma concentração de dados no campo diamantífero, sugerindo que a composição do liquído gerador das rocha das intrusões em questão favorece a preservação de diamantes (Gonzaga \& Tompkins, 1991).

Entretanto, a inexistência de macrocristais de cromita com alta porcentagem de $\mathrm{Cr}_{2} \mathrm{O}_{3} \mathrm{e}$ granadas do tipo G-10 e/ou granadas eclogíticas com alto teores de $\mathrm{Na}_{2} \mathrm{O}$, aliados às características composicionais das olivinas das duas intrusões aqui apresentadas (embora possuam teores elevados de $\mathrm{NiO},>0,10 \%$, não apresentam os altos teores esperados para 
$\mathrm{CaO},>0,5 \%$ e $\mathrm{Cr}_{2} \mathrm{O}_{3}>0,3 \%$ ) frustam qualquer propensão à mineralização de diamante. Isto porque, aparentemente, essas intrusões não amostraram xenólitos e macrocristais situados dentro da região do campo de estabilidade dos diamantes.

Os piroxênios, último mineral indicador de mineralização, não podem ser utilizados no atual estágio da pesquisa para determinações de parâmetros intensivos, como geobarômetros conforme proposto por Nimis \& Ulmer (1998), tendo em vista à falta de determinações dos volumes das células unitárias e dos sítios M1.

Por fim, a presença dos xenólitos duníticos e piroxeníticos estudados no presente trabalho permite, tentativamente, estimar a região de geração destes kimberlítos na litosfera numa profundidade de aproximadamente $100 \mathrm{~km}$, em concordância com o proposto por Dawson (1980).

No entanto, vale ressaltar que para determinações mais acuradas sobre a região fonte de geração de magmas na litosfera e sua afinidade faz-se necessário estudos de detalhe envolvendo uma criteriosa determinação da química global, geoquímica de elementos traço e geoquímica isotópica das rochas que às compõem. 


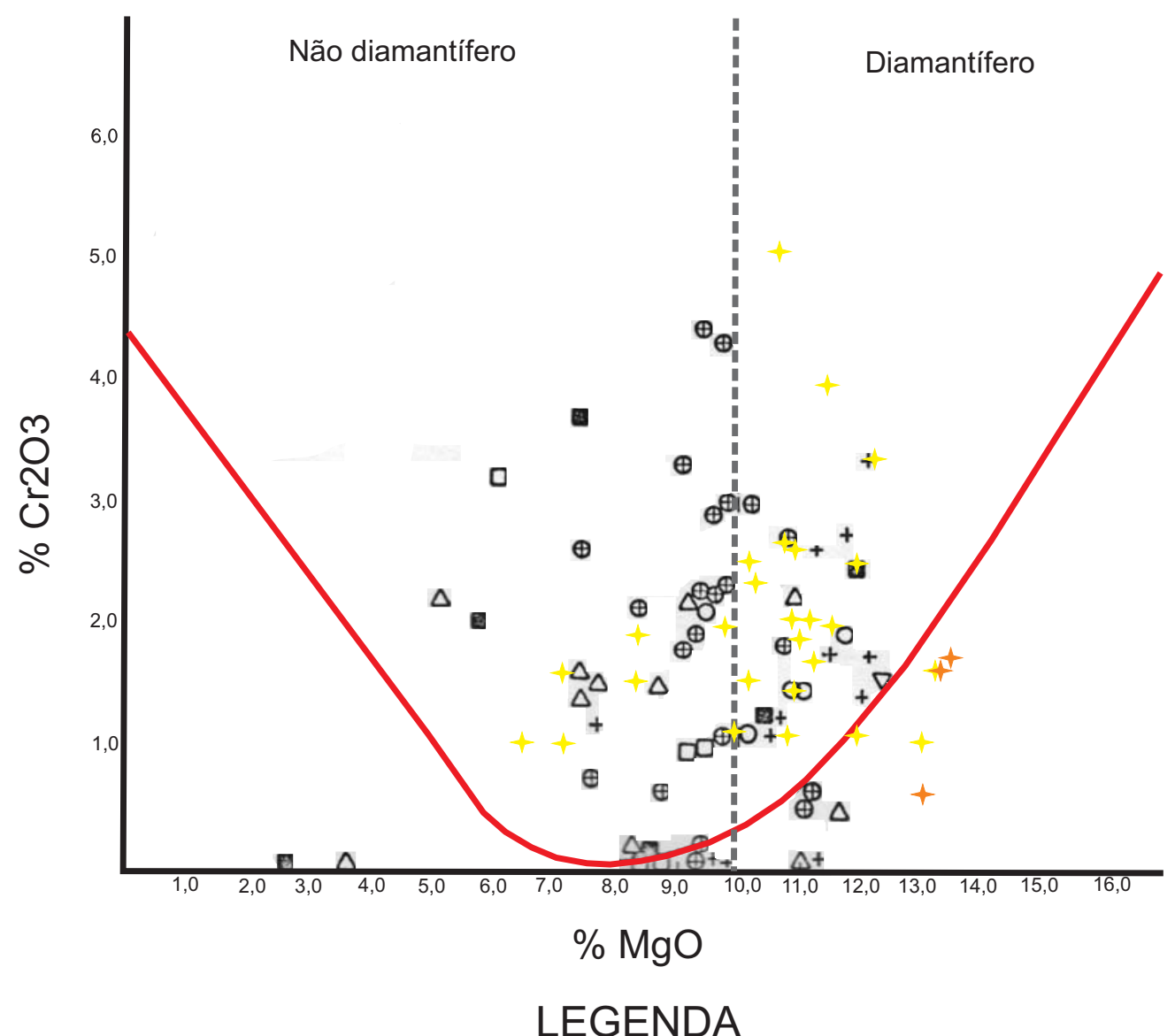

\title{
LEGENDA
}

\author{
Indaiá I \\ + Indaiá II \\ Poço Verde \\ Mamões \\ Santa Clara \\ $\triangle$ Vargem - 2 \\ $\bigoplus$ Japecanga \\ + Romaria \\ $\nabla$ Indaiá
}

Figura 47. Composições de ilmenitas do segmento Brasiliano e das intrusões Indaiá I e Indaiá II, locadas em diagrama $\mathrm{Cr} 2 \mathrm{O} 3$ vs $\mathrm{MgO}(\% \mathrm{~mol})$. Curva parabólica proposta por Haggerty (1975) e divisão dos campos diamantíferos e não diamantiferos proposta por Parfenoff (1982). Modificado de Gonzaga \& Tompkins, 1991. 


\section{Conclusões}

As rochas máfica-ultramáficas, potássica-ultrapotássicas com afinidade a kimberlitos, orangeítos, kamafugitos, lamproítos e lamprófiros, na Província Ígnea do Alto Paranaíba, centralizam-se em região que se estende entre as cidades de Catalão, a noroeste e Tapira, ao sul, comumente concentradas em área alongada segundo $\mathrm{N} 30 \mathrm{~W}$, perfazendo aproximadamente $250 \mathrm{~km}$ de extensão e $70 \mathrm{~km}$ de largura. Essas suítes encontram-se à margem oeste do Cráton do São Francisco, alojadas em litologias pertencentes ao Cráton e a Faixa Brasília.

Petrograficamente, as rochas da intrusão Indaiá I são porfiríticas seriadas, devido à onipresença de macrocristais (alguns xenocristais) milimétricos $(0,5$ a $4 \mathrm{~mm})$ e fenocristais anédricos a subédricos de olivina, opacos e mais raramente de ortopiroxênios (enstatita), imersos em matriz afanítica, composta por cristais anédricos de olivina, minerais opacos, monticellita tabular, cristais amarronzados subédricos de perovskita, clinopiroxênio (diopsídio) esverdeado e carbonatos. Xenólitos milimétricos a centimétricos (2 a $30 \mathrm{~mm}$ ), na maioria das vezes arredondados a elípticos, esverdeados, são representados por litotipos dunítico, piroxenítico, carbonático e "lapilli".

Por outro lado, as rochas da intrusão Indaiá II são também porfiríticas devido à presença de fenocristais milimétricos $(0,5$ a $2 \mathrm{~mm})$, anédricos a subédricos de olivina, fixados em matriz afanítica, contendo alguns microfenocristais prismáticos a subédricos de clinopiroxênio diopsídico esverdeado, cristais anédricos de minerais opacos associados a espinélio avermelhado, cristais subédricos a anédricos de perovskita, grãos arredondados de olivina e também raro vidro intersticial, embora já devidrificado. São observados evidentes sinais de fluxo ou orientação de fenocristais e xenólitos. Além disso, as rochas exibem três tipos de microvenulações, a primeira constituída por agregado de mineral incolor a levemente amarelado, com extinção ondulante; a segunda de vidro parcialmente devitrificado; e a terceira, de mineral amarelo pálido (scherbakovita?) dispersas pela matriz. Xenólitos afaníticos, de coloração mais clara (microcristalinos e nefeliníticos) ou escura (duníticos, carbonatíticos e "lapilli") que a matriz da rocha hospedeira são abundantes. Apresentam tamanho milimétrico (0,5 a $8 \mathrm{~mm})$ e comumente são estirados e com bordas irregulares.

A química mineral da intrusão Indaiá I denota cristais de olivina crisolita - forsterita com $\mathrm{Mg} / \mathrm{Mg}+\mathrm{Fe}^{2+}$ variando de 83 a 95, piroxênio enstatita $\left(\mathrm{En}_{85,3} \mathrm{Fs}_{12,7} \mathrm{Wo}_{1,54}\right)$, ilmenita magnesiana, cromita (Es $\left.{ }_{16,8} \mathrm{Mag}_{30,9} \mathrm{Cr}_{52,3}\right)$, espinélio $\left(\mathrm{Es}_{59,7} \mathrm{Mag}_{1,5} \mathrm{Cr}_{38,8}\right)$, magnetita $\left(\mathrm{Es}_{4,8} \mathrm{Mag}_{81,9} \mathrm{Cr}_{13,2}\right)$, monticellita com cerca de $92 \%$ do membro final $\mathrm{CaMgSiO}_{4}$ e perovskitas com cerca de $93 \%$ do membro final $\mathrm{CaTiO}_{3}$. 
Já na intrusão Indaiá II, a química mineral revela cristais de olivina crisolita - forsterita com $\mathrm{Mg} / \mathrm{Mg}+\mathrm{Fe}^{2+}$ variando de 83 a 93, piroxênios diopsídio $\left(\mathrm{En}_{39,7} \mathrm{Fs}_{10,2} \mathrm{Wo}_{48,0}\right)$, ilmenita magnesiana, cromita $\left(\mathrm{Es}_{4,4} \mathrm{Mag}_{40,0} \mathrm{Cr}_{47,0}\right)$, magnetita $\left(\mathrm{Es}_{0,9} \mathrm{Mag}_{88,9} \mathrm{Cr}_{10,2}\right)$ e perovskitas com cerca de $93 \%$ do membro final $\mathrm{CaTiO}_{3}$.

Posto o apresentado e discutido no presente trabalho sugerimos classificar as rochas das intrusões Indaiá I e Indaiá II como kimberlito pertencente ao Grupo I (Le Maitre et al., 2001).

Os dois corpos intrusivos apresentam uma assembléia mineral que sugere, de princípio, a possibilidade de existência de diamantes. As ilmenitas magnesianas presentes nessas duas intrusões possuem uma composição indicativa de um ambiente gerador favorável à preservação de diamantes. Entretanto, a inexistência de macrocristais de cromita com alta porcentagem de $\mathrm{Cr}_{2} \mathrm{O}_{3}$ e de granadas do tipo $\mathrm{G} 10$ e/ou eclogitícas com altos teores de $\mathrm{Na}_{2} \mathrm{O}$ frusta a propensão à mineralização. Isto porque, aparentemente, estas intrusões não amostraram xenólitos e macrocristais situados dentro da região do campo de estabilidade dos diamantes. 


\section{Referências Bibliográficas}

ALKMIN, F. F. 2004. O que faz de um Cráton um Cráton? O Cráton do São Francisco e as relações "almeidianas"ao delimitá-lo. In: MANTESSO-NETO, V., BARTORELli, A., CARNEIRO, C, D. R., BRITO-NEVES, B. B. (Organizadores). Geologia do Continente Sul Americano: Evolução da Obra de Fernando Flávio Marques de Almeida. p.:18 - 34.

ALKMIN, F. F., BRITO NEVES, B. B.; CASTRO ALVES, J. A. 1993. Arcabouço tectônico do Cráton do São Francisco. IN: Domingues, J. M. L. \& Misi, A. (Eds). O Cráton do São Francisco, Salvador, SBG-Ba, SE/SMG/CNPq, p. 45-62.

ALMEIDA, F. F. M. de, 1967. Origem e evolução da plataforma brasileira. DNPM. Divisão de Geologia Mineral, Rio de Janeiro. 36 p. (Boletim 241).

ALMEIDA, F. F. M. de, 1983. Relações tectônicas das rochas alcalinas mesozóicas da região meridional da plataforma sulamericana. Revista Brasileira de Geociências, 13: 139-158.

ALMEIDA, F. F. M. de, 1986. Distribuição regional e relações tectônicas do magmatismo pós-paleozóico no Brasil. Revista Brasileira de Geociências 16: 325-349.

ALMEIDA, F. F. M. de, HASUI, Y.; DAVINO, A.; HARALYI, N. L. E. 1980. Informações geofísicas sobre o oeste mineiro e seu significado geotectônico. Anais da Academia Brasileira de Ciência, Rio de Janeiro, (52): 46-60.

ALMEIDA, F. F. M. de, HASUI, BRITO NEVES, B. B. de, FUCK, R. A. 1981. Brazilian structural provinces: an introduction. Earth - Sci. Reviews, 17: $1-21$.

ALMEIDA, F. F. M. de \& SVISERO, D. P. 1991. Strutural setting and tectonic control of kimberlite of kimberlite and associated rocks of Brazil. IN: PROCEEDINGS 5TH INTERNATIONAL KIMBERLITES CONFERENCE. KIMBERLITES, RELATED ROCKS AND MANTLE XENOLITHS. CPRM, Special Publication. Brazil. p.3-5.

ARAUJO, A. L. N.; CARLSON, R. W.; GASPAR, J. C.; BIZZI, L. A. 2001. Petrology of kamafugites and kimberlites from the Alto Paranaíba Alkaline Province, Minas Gerais, Brazil. Contributions to Mineralogy and Petrology, 142: 163177.

ATKINSON, W. J.; HUGHES, F. E.; SMITH, C. B. 1983. A review of the kimberlitic rocks of wester Australia. In: J. Kornprobst (Ed.). Kimberlites I: kimberlites and related rocks. Developments in Petrology, II A, Elsevier Science Publishers, 195-224.

AZZONE, R. G.; RUBERTI, E.;SVISERO, D. P. 2002. Intrusão Pântano: kamafugito, orangeíto ou kimberlito?IN: XLI. Congr. Brás. Geologia. João Pessoa, Paraíba, Anais, pp. 534.

BARBOSA, O. 1991. Diamante no Brasil: histórico, ocorrência, prospecção e lavra, Brasília: CPRM, 136p.

BARbosA, O., BRAUN, O. P. G., DYER, R. C., CUNHA, C. A. B. 1970. Geologia da região do Triângulo Mineiro. DNPM/DFPM. 140 p. (Boletim n 136).

BIZZI, L. A.; SMITH, C. B.; WIT, M. J. de; ARMSTRONG, R. A. A. and MEYER, H. O. A. 1991. Mesozoic kimberlites and realted alkalic rocks in the south-western São Francisco Craton, Brazil: a case for local mantle resevoirs and their interaction. IN: PROCEEDINGS 5TH INTERNATIONAL KIMBERLITES CONFERENCE. KIMBERLITES, RELATED ROCKS AND MANTLE XENOLITHS. CPRM, Special Publication. Brazil. p. 156-171.

BIZZI, L. A. 1993. Mesozoic alcaline volcanism and mantle evolution of the southern São Francisco Craton, Brazil. University of Cape Tow. (PhD teses). 204p

BOSUM, W. 1973. O levantamento aeromagnético de Minas Gerais e Espírito Santo e sua conseqüência quanto a estrutura geológica. IN: Revista Brasileira de Geociências (3): 149-259.

BROD, J. A.; LEONARDOS, O. H.; MENESES, P. R.; ALMEIDA, R.; ARAÚJO, R. N. J.; BLANCO, S. B.; CARDOSO, F. B. F.;CARVALHO Jr, O. A., JUNQUEIRA, F. F.; RIEHL Jr., W.; SOUZA, J. C.F.; TALLARICO, F. H.T.;THONSEM, F. P. R.; ALBUQUERQUE, M.A. C.; BERBET, M. L. C.; CERQUEIRA, M. R. S.; CHAGAS, M. A.; DIAS, R. R.; LIMA, C. V.; NAKAMURA, E. T.; PORTO, P. A.; SANTOS, P. C. V. 1991. Tectono-estratigrafia da Faixa Brasília na região do Alto Paranaíba. ANAIS DO III SIMPÓSIO DE GEOLOGIA DO CENTRO-OESTE. Cuiabá.

CAMPOS, J. E. G. \& DARDENNE, M. A. 1997a. Origem e evolução tectônica da Bacia Sanfranciscana. Revista Brasileira de Geologia, 27(3): 283-294.

CAMPOS, J. E. G. \& DARDENNE, M. A. 1997b. Estratigrafia e sedimentação da bacia Sanfranciscana: uma revisão. IN: Revista Brasileira de Geociências. 27(3): 269-282. 
CAMPOS NETO, M. C. \& CABY, R. 1999. Neoproterozoic high - pressure metamorphism and tectonic constraint from the nappe system south of the São Francisco Craton, Southeast Brazil. Precambrian Res., 97: 3 - 26.

CAMPOS NETO, M. C. \& CABY, R. 2000. Terrane accretion and upward extrusion of high - pressure granulites in the Neoproterozoic nappes of Southern Brazil: petrological and structural constraints. Tectonics, 19: 669 - 687

CARLSON, R. W.; ESPERANÇA, S.; SVISERO, D. P. 1996. Chemical and isotopic study of cretaceous potassic rocks from SE Brazil. Contributions to Mineralogy and Petrology, 125: 393-405.

CARMICHAEL, I. S. E. 1974. The iron-titanium oxides of salic volcanic rocks and their associated ferromagnesian silicates. Contr. Miner. Petrol., 5: 310-357.

CAWTHORN, R. G. \& COLLERSON, K. D. 1974. The recalculation of pyroxene end-member parameters and estimation of ferrous and ferric iron contend from electron microprobe analyses. Amer. Mineral., 59: 1203-1208.

CHANG, H. K.; MIRANDA, F. F.; MAGALHÃES, L.; ALKMIN, F. F. 1988. Considerações sobre a evolução tectônica da Bacia do São Francisco. IN: CONGRESSO BRASILEIRO DE GEOLOGIA, 35, Belém, 1988. Anais... Belém, SBG, (5): 2076-2090.

CLEMENT, C. R.; SKINNER, E. M. W.; SCOTT-SMITH, B. H. 1984. Kimberlite redefined. Journal of Geology, (92):223228.

CLEMENT, C. R.\& SKINNER, E. M. W. 1985. A textural - genetic classifications of kimberlites. Trans. Geol. Soc. Afr., (88): 403-409.

CORDANI, U.G, \& HASUI, Y., 1968. Idades potássio-argônio de rochas eruptivas mesozóicas do oeste mineiro e sul de Goiás. IN: CONGRESSO BRASILEIRO DE GEOLOGIA, 22, Belo Horizonte, 1968. Anais... Belo Horizonte, SBG, p. 139-143.

CORDANI, U. G., SATO, K., TEIXEIRA, W., TASSINARI, C. C. G., BASEI, M. A. S. 2000. Crustal evolution of the South American Platform. . IN: CORDANI, U. G., MILANI, E. J., THOMAZ FILHO, A., CAMPOS, D. A. Eds. Tectonic Evolution of South America. Rio de Janeiro. 31st International Geological Congresss. p. 19-40.

COSTA, L. A. M. \& ANGEIRAS, A. G. 1971. Geosynclinal Evolution in the Epi - Baikalian Plataform of Central Brazil, Geologische Rundschau, 60: 1024 - 1050.

COSTA, M. T. 1963. Estrutura geológica dos Cerrados. Departamento de Pesquisa e Exper. Agrop. Min. Agric., Bol. № 15.

DANNI, J. C. \& SACARTEZINI, A. A. 1990. O olivina leucitito de Pântano e a natureza do vulcanismo da Formação da Mata da Corda, Minas Gerais. Revista Brasileira de Geociências. 20 (1-4): 83-87.

DARDENNE, M. A. 2000. The Brasilia fold belt. In: CORDANI, U. G., MILANI, E. J., THOMAZ FILHO, A., CAMPOS, D. A. Eds. Tectonic Evolution of South America. Rio de Janeiro. $31^{\text {ST }}$ International Geological Congresss. p. 231263.

DAWSON, J. B. 1980. Kimberlites and xenoliths. Springer-Verlag. New York. 250 p.

ESPERANÇA, S., MURRAY, D. C., LAMBERT, D. D. and SVISERO, D. P. 1995. The major and trace element geochemistry of garnets from the Vargem 1 kimberlite pipe, Minas Gerais State, Brazil. Anais da Academia Brasileira de Ciências. 67 (Suplemento 2): 293-306.

FUCK, R. A., JARDIM DE SÁ, E. M., PIMENTEL, M. M., DARDENNE, M. A., SOARES, A. C. P. 1993. As faixas de dobramentos marginais do Cráton do São Francisco: síntese dos conhecimentos. IN: J. M. L. Domingues, A. Misi (eds). O CRÁTON DO SÃO FRANCISCO. Salvador. BA. SBG/SGM/CNPq, p: 161-185.

GIBSON, S. A.; THOMPSON, R. N.; LEONARDOS, O. H.; DICKIN, A. P.; MITCHELL, L. G. 1995. The late cretaceous impact of the Trindade Mantle plume: evidence from large volume mafic, potassic magmatism in SE Brazil. Jornal of Petrology, 36: 189-229.

GIBSON, S. A.; THOMPSON, R. N.;WESKA, R. K.; DICKIN, A. P.; LEONARDOS, O. H. 1997. Late Cretaceous rift related upwelling and melting of the Trindade starting mantle plume head beneath western Brazil. IN: Contrib. Mineral. Petrol. (126): $303-314$.

GOMES, C. B., (coordenador) 1984. Técnicas analíticas instrumentais aplicadas à geologia. Ed. Edgard Blucher. São Paulo. $208 \mathrm{p}$.

GOMES, C. B.; RUBERTI, E.; MORBIDELLI, L. 1990. Carboantite complexes from Brazil: a review. Journal of South Americam Earth Science (3): 51-63. 
GONZAGA, G. M.; TEIXEIRA, N. A.; GASPAR, J. C. 1994. The origin of diamonds in western Minas Gerais, Brasil. Mineral Deposita (29): 414-421.

GONZAGA, G. M. \& TOMPKINS, L. A. 1991. Geologia do Diamante. IN: SCHOBBENHAUS, C.; QUEIROZ, E. T.; COELHO, C. E. S. PRINCIPAIS DEPÓSITOS MINERAIS DO BRASIL Brasília, volume IV parte A. 53-116.

GUIMARÃES, D. 1933. A província magmática do Brasil meridional. Brasil. Serviço Geológico Mineiro. Boletim 64.70 p.

GROSSI SAD,J. H.; CARDOSO, R. N.; COSTA, M. T.1971. Formações cretácicas em Minas Gerais: uma revisão. Revista Brasileira de Geociências, (1): 3-13.

HAGGERTY, S. E. 1975. The chemistry and gênesis of opaque minerals in Kimberlites. IN: L. H. AHRENS; DAWSON, A. R. DUNCAN; A. J. ERLANK, editors. Physics and Chemistry of the Earth, 9: 295 - 307.

HAGGERTY, S. E. 1995. Upper Mantle Mineralogy. Proceedings of theInternational Symposium on the Physics and Chemistry of the Upper Mantle (ISUM). Journal of Geodynamics, 20 (4): 331 - 364.

HASUI, Y. \& PENALVA, F. 1970. O problema do diamante do Alto Paranaíba, Estado de Minas Gerais. Boletim da Sociedade Brasileira de Geologia (19): 71-78.

HASUI, Y., SADOWSKI, G. R., SUGUIO, K., FUCK, G. F. 1975. The Phanerozoic Tectonic Evolution of the Western Minas Gerais State. Anais da Academia Brasileira de Ciências, 47 (3/4): 431-438.

HASUI, Y. \& HARALYI, N. L. E. 1991. Aspectos Lito-Estruturais e Geofísicos do soerguimento do Alto Paranaíba. Geociências. São Paulo, (10): 57-77.

HAWTHORNE, J. B. 1975. Model of a kimberlite pipe. IN: L.H. Ahrens; J. B. Duncam; A. J. Erlank (Eds.). Phisics and Chemistry of the Earth (9): 1-15.

HERZ, N. 1977. Timing and spreading in the South Atlhantic: informations from brasilian alcalines rocks. Geological Society of American Bulletin, (88): 101-112.

JAQUES, A. L.; LEWIS, J. D.; SMITH, C. B.; GREGORY, G. P.; FERGUSON, J.;CHAPPEL, B. W.; McCULLOC, M. T. 1984. The diamond-bearing ultrapotassic (lamproitic) rocks of the west Kimberley region, western Australia. IN: J. Kornprobst (Ed.). Kimberlites I: kimberlites and related rocks. Developments in Petrology, II A, Elsevier Science Publishers, 225-254.

LADEIRA, E. A.; BRAUN, O. P. G.; CARDOSO, R. N.; HASUI, Y. 1971. O Cretáceo em Minas Gerais - Mesa Redonda. IN: CONGRESSO BRASILEIRO DE GEOLOGIA, 25, Belo Horizonte, 1968. Anais... Belo Horizonte, SBG, (1): 1531 .

LE MAITRE, R. W. 1989. A classification of igneous rocks and glossary of terms. Blackwell Scientific Publications.

2001. A classification of igneous rocks and glossary of terms. Blackwell Scientific Publications.

LEONARDOS, O. H. \& FYFE, W. S., 1974. Ultrametamorphism and melting of a continental margem um the Rio de Janeiro region, Brazil. Contributions to Mineralogy and Petrology, 46: 201-214.

LEONARDOS, O. H. \& ULBRICH, M. N. 1987. Lamproítos de Presidente Olegário, Minas Gerais. IN: REUNIÃO ANUAL SBCP, 36. Brasília. Resumos... Brasília, SPPC.

LEONARDOS, O. H., ULBRICH, M. N., GASPAR, J. C., 1991. The Mata da corda Volcanic Rocks. Proceeding of the fifth international kimberlites Conference. IN: Kimberlites, realted rocks and mantle xenoliths. CPRM, Special Publication. 3/91. Brazil. p. 66-73.

LEONARDOS, O. H.; GIBSON, S. A.; THOMPSON, R. N.; MOREIRA FILHO, R.D.; MAGALHÃES. A.C. 1993. Geoquímica da intrusão ultramáfica ultrapotássica da Bocaina, Minas Gerais/Goiás: mais um exemplo de rocha sem classificação na província magmática do Alto Paranaíba. IN: Simpósio Brasileiro da Geologia do Diamante, 1. Anais...Cuiabá. UFMT. Publicação Especial. 2/93. p. 129-140.

LLOYD, F. E.; HUNTINGDON, A. T.; DAVIES, G. R.; NIXON, P. H. 1991. Phanerozoic volcanism of south west Uganda: a case for regional $\mathrm{k}$ and LILE enrichment of the lithosfere beneath a domed and rifted continental plate. IN: Kampuzu, A. B.; Lubala, T. T. (Eds.). Magmatism in extensional strutural settings: the Phanerozoic African Plate, Springer-Verlag, p.: 23-72.

MARINI, O. J.; FUCK, R. A.; DANNI, J. C.; DARDENNE, M. A. 1981. A evolução geotectônica da Faixa Brasília e do seu embasamento. IN Simpósio sobre o Cráton do São Francisco e suas faixas marginais, 1, Salvador. Anais..., Salvador, p. $100-105$. 
MELLUSO, L.; LUSTRINO, M.; RUBERTI, E.; BROTZU, P.; GOMES, C. B.; MORBIDELLI, L.;MORRA, V., SVISERO, D. P.; D' AMELIO, F. 2008 - em publicação. Major and trace element abundances of olivine, clinopyroxene, perovskite, phlogopite and $\mathrm{Cr}-\mathrm{Fe}-\mathrm{Ti}$ oxides im Brazilian kamafugitic rocks: implications for element partitioning in natural samples. Canadian Mineralogist.

MEYER, H. O. A.; HAGGERTY, S. E.; SVISERO, D. P. 1986. Oxide and silicate minerals in the kimberlites of Minas Gerais, Brazil (Extended Abstract). $4^{\text {th }}$ International Kimberlites Conference, Perth, Australia.

MEYER, H. O. A.; GARWOOD, B. L; SVISERO, D. P.; SMITH, C. B. 1991. Alkaline ultrabasic intrusions in western Minas Gerais, Brazil. In: Proceedings 5th International Kimberlites Conference. IN: Kimberlites, related rocks and mantle xenoliths. CPRM, Special Publication. Brazil. p. 140-155.

MEYER, H. O. A.; GARWOOD, B. L; SVISERO, D. P.; SMITH, C. B. 1991. The Pântano Intrusion. In: Proceedings $5^{\text {th }}$ International Kimberlites Conference. In: Kimberlites Conference, Field Guide Book, CPRM, Special Publication. Brazil. 3\9, p. 59-63.

MITCHELL, R. H., 1985. A review of the mineralogy of lamproites. Transactions of the Geological Society of South Africa, (88): 411-437.

MITCHELL, R. H., 1986. Kimberlites - Mineralogy, geochemistry, and petrology. Plenum Press. New York en London. $442 \mathrm{p}$.

MITCHELL, R. H. 1994. Suggestions for revisions to the terminology of kimberlites and lamprophires from a genetic viewpoint. In: Proceedings 5th International Kimberlites Conference. IN: Kimberlites, related rocks and mantle xenoliths. CPRM, Special Publication. Brazil. p. 15-26.

MITCHELL, R. H. 1995. Kimberlites, Orangeites, and related rocks. Plenum Press, New York. 410 p.

MITCHELL, R. H. \& BERGMAN, D. C. 1991. Petrology of lamproites. Plenum Press, New York. 447 p.

MORAES, L. C.; SEER, H. J.; KATTAH, S. S. 1987. Aspectos petroquímicos das rochas vulcânicas alcalinas cretáceas da poção meridional da Bacia Sanfranciscana, MG. IN: Congresso Brasileiro de Geoquímica. Porto Alegre. Anais.... Porto Alegre, SBG. (1):315-3128.

MORIMOTO, R., 1990. Nomenclatura de piroxênios. Tradução do original em inglês "Nomenclature of pyroxênes" realizada com a permissão da IMA por GARDA, M.G. e ATENCIO, D. Revista Brasileira de Geociências 20 (14):318-328.

NIMIS, P. \& ULMER, P. 1998. Clinopyroxene geobarometry of magmatic rocks. Party 1: an expanded structural geobarometer for anhydrous and hydrous, basic and ultrabasic system. Contributions Mineralogical Petrological. (133): $122-135$.

PARFENOFF, A. 1982. Un minéral traceur pour la prospection alluvionaire: L'ilménite relations entre ilménite magnésiennes, basalts alcalins, kimberlites et diamant. Documents du B.R.G.M. 37, 215 p.

PIMENTEL, M. M. \& FUCK, R. A. 1992. Neoproterozoic crustal accretion in central Brazil. Geology, (20): 375-379.

PIMENTEL, M. M., JOST, H., ARMSTTRONG, R. FUCK, R. A., JUNGES, S., RESENDE, M. G. 2000. Reappraisal of the Santa Rita Grenstone belt stratigraphy, Central Brazil, basead on new U-Pb SHRIMP age and Sm-Nd data of felsic volcanic rocks. Revista Brasileira de Geociências, 30:75 - 80.

RAMSAY, R. R. \& THOMPKINS, L. A. 1993. The geology, heavy mineral concentrate mineralogy, and diamond prospectivity of the Boa Esperança and Cana Verdes pipes, Corrego D'Anta, Minas Gerais, Brazil. In: Meyer, H. O. A. \& Leonardos, O. H. (Eds.). Proceedings 5th International Kimberlites Conference. In: Kimberlites, related rocks and mantle xenoliths. CPRM, Special Publication. Brazil. Volume 1B.

RIMANN, E. 1917. O Kimberlito no Brasil. Ouro Preto. Escola de Minas, Anuário 15: 27-32.

SAADI, A.; VALADÃO, R. C.; SILVEIRA, J. S. 1991. Vulcanismo extrusivo e tectônica cretácea no centro-sul de Minas. Boletim do $3^{\circ}$ Simpósio Nacional de Estudos Tectônicos: 88-90.

SCOTT- SMITH, B. H. 1992. Contrasting kimberlites and lamproites. Explor. Mining Geol. (1): 371-382.

SCOTT- SMITH, B. H. \& SKINNER, E. M. W. 1984. Diamontiferous lamproites. In: Journal of Geology (92): 433-438.

SEER, H. J. 1999. Evolução Tectônica dos Grupos Araxá, Ibiá e Canastra na sinforma de Araxá, Minas Gerais. Brasília, IG UNB, Tese Dout., 267 p.

SGARBI, G. N. C. 2000. The cretaceous SanFranciscan Basin, eastern plateau of Brazil. Revista Brasileira de Geociências, 30: $450-452$. 
SGARBI, G. N. C. \& LADEIRA, E.A. 1995. Ventifacts of Cretaceous Proterozoic uncorformity in the Alto Paranaíba region, west of Minas Gerais state, Brazil. Geociências (14-1):119-151.

SGARBI, G. N. C. \& DARDENNE, M. A. 1997. Evolução climática do Gondwana nas regiões centro-sul do Brasil e seus registros geológicos continentais durante o Mesozóico, enfatizando o Arco do Alto Paranaíba, a borda NNE da Bacia do Paraná e a porção meridional da Bacia Sanfranciscana, no oeste do Estado de Minas Gerais. Geonomos, (4-1): 2149.

SGARBI, G. N. C.; SGARBI, P. B. de A.; BRITO, W. 1998a. Conglomerados cretácicos e suas relações com o vulcanismo alcalino no oeste mineiro. IN: SBG, Congresso Brasileiro de Geologia, 40, Belo Horizonte, Anais, 1997.

SGARBI, G. N. C.; GROSSI SAD, J. H.; HORN A. H.; SEER, H. J.; BRITO, W. 1998b. Alto do Paranaíba Arch (APA) and the rio Parapetinga Sequence (RPS): Cretaceous paleogeography and provenance área in western Minas Gerais State. IN: SBG, Congresso Brasileiro de Geologia, 40, Belo Horizonte, Anais, 1993.

SGARBI, G. N. C.; SGARBI, P. B. A.; CAMPOS, J. E. G.; DARDENNE, M. A.; PENHA, U. C. 2001. Bacia Sanfranciscana: o registro fanerozóico da Bacia do São Francisco. IN: PINTO, C. P. \& MARTINS - NETO, M. A. A Bacia do São Francisco. Geologia e Recursos Naturais. SBG/MG. Belo Horizonte. 93-138.

SGARBI, P. B. de A. 1991. Petrografia e Geoquímica da Formação Mata da Corda na região de Carmo do Paranaíba, MG. Universidade Federal do Rio de Janeiro, Dissertação de Mestrado, 214 p.

SGARBI, P. B. A. \& VALENÇA, J. G. 1993. Kalsilite in brasilian kamafugitic rocks. Mineralogical Magazine (57): 165171.

SGARBI, P. B. A. \& VALENÇA, J. G. 1995. Mineral and rock chemistry of Mata da Corda kamafugite rocks (MG State, Brazil). Anais da Academia Brasileira de Ciências, 67 (Suplemento 2): 257-269.

SILVA, A. N. da, MARCHETTO, M. SOUZA,O. M. de. 1979. Geologia do Complexo carbonátitico de Araxá, Minas Gerais. Mineração Metalurgia (43): 14-18.

SILVA, C. H. 2003. Evolução geológica da Faixa Brasília na região de Tapira, sudoeste de Minas Gerais, Rio Claro, IGCE UNESP, Tese Dout., 196 p.

SIMÕES, L. S. A. 1995. Evolução metamórfica da Nappe de Passos, sudoeste de Minas Gerais, São Paulo, IGc - USP, Tese de Doutoramento, $149 \mathrm{p}$.

SKINNER, E. M. W. 1986. Contrasting Group 1 and 2 kimberlite petrology: towards a genetic model for kimberlites. Fourth Int. Kimberlite Conf., Perth, Australia. Extended Abstrats, p: 202-204.

SKINNER, E. M. W. 1989. Contrasting Group 1 and 2 kimberlite petrology: towards a genetic model for kimberlites. IN Ross et al. 1989 q.v., Vol 1, p: 528-544.

SMITH, C. B. 1983. Pb, Sr and Nd isotopic eviddence for sources of African cretaceous kimberlites. Nature, 304:51-54.

SMITH, C. B., GURNEY, J. J., SKINNER, E. M. W., CLEMENT, C. R., EBRAHIM, N. 1985. Geochimical character of southern Africam kimberlites: a new approach based on isotopic constraints. Trans. Geol. Soc. S. Afr. (88): 267-280.

SVISERO, D. P., 1979. Piropos cromíferos da mina de diamantes de Romaria: composição química e origem. Recife. Boletim Mineralógico 06: 7 a 14.

SVISERO, D. P., MEYER, H. O. A.; TSAI, H. M. 1979. Kimberlites in Brazil: An Initial Report. Proceedings $2^{\text {nd }}$ International Kimberlite Conference, 1: 92-100.

SVISERO, D. P., MEYER, H. O. A. 1981. Ilmenitas kimberlíticas da mina de diamantes de Romaria, MG. Revista Brasileira de Geociências 11: 217-221.

SVISERO, D. P., MEYER, H. O. A., HARALYI, N. L. E., HASUI, Y. 1984. A note on the geology of some brasilian kimberlites. Journal of Geology. 92 (3): 331-338.

TALlARICO, F. H. B.; LEONARDOS, O. H.; GIBSON, S. A.; MEYER, H. O. A.; MITCHELL, J. C. 1993. Química mineral da intrusão da Mata do Lenço (IML), Abadia dos Dourados, MG. IN: Simpósio da Geologia do Diamante, 1. Anais...Cuiabá. UFMT, Publicação Especial 2/93. p. 114-128.

TEIXEIRA, W., SABATÉ, P., BARBOSA, J., NOCE, C. M., CARNEIRO, M. A. 2000. Archean and Paleoproterozoioc tectonic evolution of the São Francisco Craton, Brazil. In: CORDANI, U. G., MILANI, E. J., THOMAZ FILHO, A., CAMPOS, D. A. Eds. Tectonic Evolution of South America. Rio de Janeiro. $31^{\text {st }}$ International Geological Congresss. p. 101-137. 
TOMPKINS, L. A. \& GONZAGA, G. M. 1989. Diamonds in Brazil and proposed model for the origin and distribution of diamonds in the Coromandel region, Minas Gerais, Brazil. Economic Geology (84): 591-602.

TURNER, S.; REGELOUS, M.; KELLEY, S.; HAWKESWORTH, C; MANTOVANI, M. 1994. Magmatism and continental break-up in South Atlantic: high precision 40Ar/39Ar geocronology. Earth Planetary Science Letters, (12): 33-348.

VALERIANO, C. M., SIMÕES, L. S. A., TEIXEIRA, W., HEILBRON, M. 2000. Southern Brasília Belt (SE Brazil): tectonic discontinuites, K-Ar data and evolution during the Neoproterozoic Brasiliano orogeny. Revista Brasileira de Geociências, 30: 195 - 199.

VALERIANO, C. M., DARDENNE, M. A., FONSECA, M. A., SIMÕES, L. S. A., SEER, H. J. 2004. A evolução tectônica da Faixa Brasília. IN: MANTESSO-NETO, V., BARTORELli, A., CARNEIRO, C, D. R., BRITO-NEVES, B. B. (Organizadores). Geologia do Continente Sul Americano: Evolução da Obra de Fernando Flávio Marques de Almeida. p.: 575 a 592.

WOOLEY, A. R.; BERGMAN, S.; EDGAR, A. D.; LE BAS, M. J.; MITCHELL, R. H.; ROCK, N. M. S.; SCOTT-SMITH, B. H. 1996. Classification of lamprophires, lamproites, kimberlites, and the kalsilite-, melilite- and leucite-bearing rocks. Canadian Mineralogist, (34): 175-186. 